UNIVERSIDADE DE BRASÍLIA

LETÍCIA ERIG OSÓRIO DE AZAMBUJA

A TEORIA DA MORALIDADE COMUM E O PRINCÍPIO DA JUSTIÇA NA OBRA DE BEAUCHAMP \& CHILDRESS

BRASÍLIA - DF 


\section{LETÍCIA ERIG OSÓRIO DE AZAMBUJA}

\section{A TEORIA DA MORALIDADE COMUM E O PRINCÍPIO DA JUSTIÇA NA}

OBRA DE BEAUCHAMP \& CHILDRESS

Trabalho de conclusão de curso para obtenção do título de doutor em Bioética apresentado à Universidade de Brasília - UnB.

Orientador: Prof. Dr. Volnei Garrafa

\section{BRASÍLIA - DF}




\title{
A TEORIA DA MORALIDADE COMUM E O PRINCÍPIO DA JUSTIÇA NA OBRA DE BEAUCHAMP \& CHILDRESS
}

Aprovada em 19 de dezembro de 2014.

BANCA EXAMINADORA

\author{
Prof. Dr. Volnei Garrafa \\ Universidade de Brasília - UnB \\ Prof. Dr. Jan Helge Solbakk \\ Universidade de Oslo - Noruega \\ Prof. Dr. Wanderson Flor do Nascimento \\ Universidade de Brasília - UnB \\ Profa. Dra. Helena Eri Shimizu \\ Universidade de Brasília - UnB \\ Prof. Dr. Gabriele Cornelli \\ Universidade de Brasília - UnB
}

Profa. Dra. Monique Teresinha Pyrrho de Souza Silva (suplente)

Ministério da Ciência, Tecnologia e Inovação - MCTI 


\section{SUMÁRIO}

LISTA DE QUADROS . . . . . . . . . . . . . . . . . . . . . v

RESUMO ..............................

ABSTRACT $\ldots \ldots \ldots \ldots \ldots \ldots \ldots \ldots \ldots \ldots \ldots \ldots \ldots \ldots \ldots \ldots \ldots \ldots$

1. INTRODUÇÃO . . . . . . . . . . . . . . . . . . . . 8

2. BREVE HISTÓRICO DO PROCESSO DE CRIAÇÃO, DIFUSÃO E CONSOLIDAÇÃO DO PRINCIPIALISMO ................. 13

3. FUNDAMENTAÇÃO TEÓRICA $\ldots \ldots \ldots \ldots \ldots \ldots \ldots \ldots \ldots \ldots \ldots \ldots \ldots \ldots \ldots$

3.1. Teorias morais que fundamentam a obra de $B \& C \ldots \ldots \ldots \ldots \ldots \ldots 31$

3.1.1. A Teoria Utilitarista . . . . . . . . . . . . . . . . . . . 31

3.1.2. A Teoria Kantiana ............................. 33

3.1.3. A Teoria dos Direitos ............................ 34

3.1.4. A Teoria das Virtudes. . . . . . . . . . . . . . . . . . . . . . . 35

3.2. A Teoria da Moralidade Comum em B\&C. ................. 36

3.2.1. As críticas de Clouser e Gert ao uso da Teoria da Moralidade

Comum como teoria de fundamentação do Principialismo. . . . . . . .42

3.3. O Princípio da Justiça em B\&C. . . . . . . . . . . . . . . . . . . 47

3.3.1. Críticas ao Princípio da Justiça no Principialismo . . . . . . . . 49

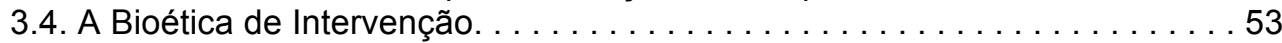

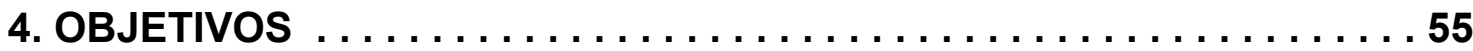

5. MÉTODO . . . . . . . . . . . . . . . . . . . . . 56

6. RESULTADOS E DISCUSSÃO. . . . . . . . . . . . . . . . . . . 61

6.1. Com relação à Teoria da Moralidade Comum . . . . . . . . . . . . . . . . . 61

6.1.1. Alterações ao longo das edições . . . . . . . . . . . . . . . . . 61

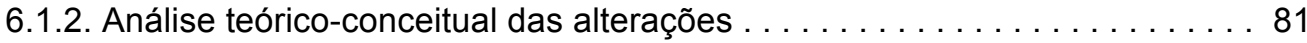

6.2. Com relação ao Princípio da Justiça . . . . . . . . . . . . . . . . . . . . 89

6.2.1. Alterações ao longo das edições . . . . . . . . . . . . . . . . . . . . 89

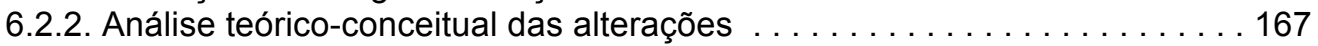

CONSIDERAÇÕES FINAIS. . . . . . . . . . . . . . . . . . . 207

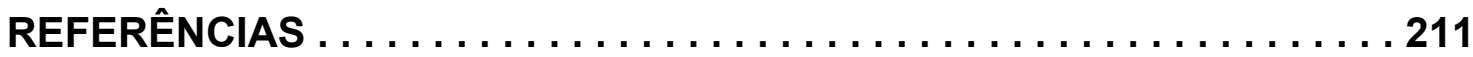




\section{LISTA DE QUADROS}

\begin{tabular}{|l|l|l|l} 
QUADRO 1. & $\begin{array}{l}\text { Quadro-resumo da cronologia das edições do livro } \\
\text { Principles of Biomedical Ethics e de alguns dos } \\
\text { principais artigos/capítulos de livro com críticas à obra - } \\
\text { fonte: a autora } \ldots \ldots \ldots \ldots \ldots \ldots \ldots \ldots \ldots \ldots \ldots \ldots\end{array}$ & $\mathbf{2 7} \ldots \ldots \ldots$
\end{tabular}




\section{RESUMO}

Principialismo é uma expressão que passou a ser internacionalmente conhecida a partir da obra "Principles of Biomedical Ethics" de autoria de Beauchamp e Childress (B\&C), considerada até hoje a principal referência deste novo campo do conhecimento denominado Bioética. Este livro fez parte decisiva do processo de consolidação e expansão mundial da Bioética a partir do final dos anos 1980 e, teve seus quatro princípios fundamentadores advindos de diferentes teorias: o Princípio da Autonomia foi retirado da Teoria Kantiana (de Kant); o da Beneficência, da Teoria Utilitarista (de Mill); o da Justiça, da Teoria da Justiça (de Rawls); e o da Não-maleficência, da Teoria da Moralidade Comum (de Gert e Clouser). A partir da década de 90, no entanto, diversas críticas surgiram ao redor do mundo com relação à homogeneidade conceitual da proposta principialista. Como resultado, transformações na obra acabaram acontecendo ao longo de suas sete edições, as quais foram objeto do presente estudo, em especial, no que tange à Teoria da Moralidade Comum (tomada da proposta de Gert e Clouser), utilizada enquanto sua própria fundamentação da $4^{a}$. edição em diante, e ao Princípio da Justiça, deixado em uma espécie de segundo plano na obra, embora sendo de especial importância para as pessoas pobres e para os países periféricos. Objetivo Geral: analisar as mudanças introduzidas pelos autores na citada obra com base nas críticas relacionadas com sua pretensa universalidade e surgidas a partir do início dos anos 1990. Objetivos Específicos: apresentar criticamente a inclusão da Teoria da Moralidade Comum como fundamento teórico de sustentação do Principialismo a partir da $4^{a}$. edição, comparando com o conteúdo existente nas edições subsequentes; apresentar criticamente as mudanças que ocorreram nas diferentes edições com relação ao Princípio da Justiça; e discutir como a Bioética de Intervenção - corrente epistemológica de origem latino-americana da Bioética - trabalhou o problema da falta de contextualização dos institutos do Principialismo às diferentes realidades dos países periféricos do mundo. No método, trata-se de pesquisa qualitativa, com estudo descritivo e analítico de conteúdo de literatura pré-selecionada, das sete edições do livro "Principles of Biomedical Ethics" nas suas edições originais em inglês. Buscou-se a presença das unidades de registro e de contexto "Teoria da Moralidade Comum" "como teoria de fundamentação do Principialismo" e "Princípio da Justiça" "no Principialismo" (respectivamente), esta última assim categorizada: moralidade comum; Bioética; saúde como um bem; mínimo existencial; confidencialidade; privacidade; vulnerabilidade; exploração; discriminação; busca do bem-estar; equidade; seleção de pacientes; alocação de recursos; princípio da necessidade; pesquisa clínica; justa oportunidade; justiça distributiva; capacidade para pagar; prevenção; e teorias do princípio da justiça na obra. A fase de exploração do material incluiu um trabalho de fichamento com a transcrição do material selecionado a tabelas, sua comparação e análise. Nos resultados, verificou-se que a utilização da Teoria da Moralidade Comum como fundamentação do Principialismo iniciou na 4a. edição. A moralidade comum foi trabalhada de forma diferente ao longo das edições, com os autores procurando comprovar a existência de universalismo no Principialismo - o que não aconteceu. Com relação ao Princípio da Justiça, para B\&C a saúde representa um "bem" (e não um direito), devendo prevalecer as leis de livre mercado com relação ao seu acesso. Não sendo considerada como um direito, a saúde, de acordo com os autores, deve ser distribuída segundo critérios de capacidade de cada pessoa para pagar por esse benefício. A 6a. e a 7a. sétima edição podem ser consideradas as que mais aproximaram da interpretação internacionalmente reconhecida de que o acesso à saúde constitui um direito humano. Contudo, na obra como um todo, diversos temas relevantes à Bioética latino-americana - como os temas da escassez de recursos, exclusão social, marginalização e pobreza, entre outros - ou foram excluídos ou foram enfocados sob o ponto de vista exclusivamente econômico-financeiro. Isso tudo reflete a impossibilidade de o Principialismo ser aplicado universalmente do ponto de vista teórico-estrutural, conforme levantado nesta tese, respeitando as condições sócio-econômicas e culturais específicas de cada país ou região, aspecto considerado, por exemplo, na Declaração Universal sobre Bioética e Direitos Humanos. Na América Latina, especificamente, a Bioética de Intervenção trabalha temas relacionados com a justiça distributiva e outras questões históricas existentes na região a partir de um enfoque sócio-político que tem como base o critério universal dos direitos humanos, e não a partir da proposição economicista de limitação do acesso das pessoas a um determinado benefício por uma questão de custo-benefício, onde o mínimo existencial não representa sequer um direito básico de cidadania.

DESCRITORES: Bioética, Princípios, Principialismo, Críticas, Bioética de Intervenção, Teoria da Moralidade Comum, Princípio da Justiça. 


\begin{abstract}
Principlism is an expression that started to be internationally known because of the work "Principles of Biomedical Ethics", made by Beauchamp and Childress (B\&C), considered until today the principal reference of the new knowledge field named Bioethics. This book was a decisive part in the process of consolidation and global expansion from the late $80 \mathrm{~s}$ and had its four fundamental principles based on different theories: the Principle of Autonomy has came from the Kantian Theory (by Kant); the Beneficence, from the Utilitarian Theory (by Mill); the Justice, from the Theory of Justice (by Rawls); and the Non-maleficence, from the Common Morality Theory (by Gert and Clouser). From the nineties, although, several criticisms came along the world related to the conceptual homogeneity of the Principialist proposal. As a result, changes occurred along its seven editions, object of the present study, specially, in what concerns about and the Common Morality Theory (taken by Gert and Clouser), used as the Principlism's foundation from the 4th edition on, and the Principle of Justice, left in a kind of second place in the study, even being of special interest for the poor people and the periphery countries. General Objective: analyze the changes introduced by the authors in the aforementioned work based on criticism regarding its alleged universality and emerged in the early 1990s. Specific Objective: critically present the inclusion of the Common Morality Theory as the theoretical foundation of Principlism from the 4th edition, comparing with the content in the next editions; critically present the changes occurred in the editions regarding the Principle of Justice; and understand how the Hard Bioethics - epistemological study that came from the Latin-American Bioethics - dialled with the problem of absence of contextualization in the institutes of Principlism when face to the different realities of the periphery countries. In the method, this is a qualitative study, using descriptive and analytical method by the study of pre-selected literature consisted in the seven editions of the book "Principles of Biomedical Ethics" in its original versions in English. Is has looked after the register and context units "Common Morality Theory" "as the foundation theory of Principlism" and "Principle of Justice" "in Principlism" (respectively), this last categorized as: common morality; bioethics; health as a good; decent minimum; confidentiality; privacy; vulnerability; exploitation; discrimination; welfare; equity; selection of patients; resources rationing; principle of need; clinical research; fair opportunity; distributive justice; ability to pay; prevention; and theories of the principle of justice existing in the work. The exploration phase included a book report with the transcription of the material to tables, its comparison and analysis. As results, we found that the use of the Common Morality Theory, taken from Gert and Clouser theory, as the foundation of Principlism has began in the $4^{\text {th }}$ edition. The common morality has been treated differently over the editions, as the authors seek to prove the existence of universality in Principlism - what did not happen. In what concerns the Principle of Justice, for B\&C, health is a "good" (not a right), should prevailing free market laws regarding to its access. As not a right, health, according to the authors, should be distributed according criteria of ability of each one to pay for its benefit. The $6^{\text {th }}$ and the $7^{\text {th }}$ edition can be considered the ones that gotten more close to the internationally recognized interpretation that access to health constitutes a human right. Although, taking the whole study, several relevant themes to Latin Bioethics - as the lack of resources, social exclusion, marginalization and poverty, among others - or have been excluded or taken from the exclusively economic-financial point of view. All this reflects not only the impossibility of the universal application of the Principlism from the theorist-conceptual point of view, as here raised, but also respecting the socio-economical and cultural conditions of each country or region, aspect considered, for example, in the Universal Declaration of Bioethics and Human Rights. In the Latin America, specifically, Hard Bioethics works themes related to distributive justice and other historical issues existent in the region starting from an socio-political focus that has as its basis the universal criterion of human rights, not from the economic proposal of limitation of the access of people to an specific benefit as a matter of cost-benefit, where the decent minimum doesn't represent not even one basic right of citizenship.
\end{abstract}

KEYWORDS: Bioethics, Principles, Principlism, Criticism, Hard Bioethics, Common Morality Theory, Principle of Justice. 


\section{INTRODUÇÃO}

A história da Bioética, em grande parte, se confunde com o próprio histórico do Principialismo, já que foi este um dos maiores responsáveis pela consolidação e expansão mundial desta a partir do final dos anos $1980^{1}$. Sua praticidade de aplicação concreta, assim como as críticas que recebeu nesta fase, ao mesmo tempo em que fomentaram o surgimento de novas edições da obra de Beauchamp \& Childress (B\&C), também contribuíam à expansão da própria Bioética mundialmente.

No entanto, este Principialismo, mesmo tendo tido $3 / 4$ de sua fundamentação principiológica baseada no Relatório Belmont - um documento excusivamente direcionado à ética em pesquisa e que teve um de seus autores (Beauchamp) em comum - deixou em segundo plano os temas de cunho social e afeto à realidade de países periféricos ${ }^{1,2,3}$.

Assim, aquela concepção potteriana inicial de uma Bioética ampla e globalizada foi dominada pela concepção hellegeriana, de visão autonomista anglo-saxônica e voltada exclusivamente às questões biomédicas ${ }^{4,5}$. E foi este Principialismo, criticado a partir dos anos 1990 por não ser suficiente para refletir uma Bioética mais ampla como aquela idealizada por Potter, que, dentre outros modelos surgidos na época, predominou neste período.

Nele, quatro princípios - beneficência, justiça, autonomia e nãomaleficência - oriundos de teorias morais diferentes, a de Mill, a de Rawls, a de Kant e a de Gert e Clouser (respectivamente) foram apresentados como forma de solução simplificada de conflitos morais ${ }^{6,7}$. Tais princípios, além de propostos pelo Principialismo, também o foram por suas próprias teorias de origem, assim como por outros pensadores muito antes de se começar a pensar em Bioética. 
Os princípios da beneficência e da justiça foram trabalhados por Ross, ainda em $1930^{9}$. Posteriormente, estes dois mesmos princípios foram teoricamente desenvolvidos por Frankena, em 1963, assim como também compunham o rol estabelecido pelo Relatório Belmont, em $1978^{2,8}$.

Outro princípio componente do Principialismo, o do respeito pela autonomia (ou simplesmente autonomia), também estava contido no Relatório Belmont, mas com uma nova roupagem para o que inicialmente fora denominado de "princípio do respeito pelas pessoas". Por fim, o princípio da não-maleficência era o terceiro dos três deveres prima facie de Ross ${ }^{9}$.

No entanto outras propostas principialistas (no sentido de utilizarem "princípios") existiram. Como exemplo de autor que mereceu destaque em suas colocações, tem-se Veatch, que propôs a solução de conflitos entre princípios pelo uso de balanceamento e ranqueamento deles. Ele também defende um modelo contratualista, onde as decisões são tomadas de acordo com as circunstâncias, destacando a vulnerabilidade dos pacientes ${ }^{10}$.

Outro autor que não se pode esquecer de mencionar é Engelhardt, um bioeticista cristão, mas que defendeu em sua obra ideias seculares, superpondo a autonomia aos demais princípio e inclusive renomeado-o de "princípio do consentimento" 10 .

A partir da década de 90, vários textos começaram a levantar críticas à utilização desses quatro princípios como padrão único de avaliação para os dilemas bioéticos, onde se destacam: a pretensa universalidade dos princípios frente aos relativismos culturais $^{11}$, a supervalorização da autonomia em detrimento dos outros princípios ${ }^{11}$, a concepção despolitizada e asséptica da obra frente a certos problemas sociais ${ }^{12}$, o sub-dimensionamento do Princípio da Justiça com relação aos demais ${ }^{13,14}$, e a incorporação da Teoria da Moralidade Comum como sua própria de fundamentação (o que aconteceu apenas a partir da $4^{\mathrm{a}}$. edição $)^{15}$. 
Como respostas a tais críticas, a obra de $\mathrm{B} \& \mathrm{C}$ acabou sofrendo algumas transformções ao longo de suas edições ${ }^{1}$. Apesar de mudanças significativas terem sido implementadas na atual $7^{\mathrm{a}}$. edição, pode-se perceber que foi, na verdade, a $4^{a}$. edição o marco significativo da obra, em vista de sua substantiva mudança de fundamentação teórica em relação às anteriores ${ }^{16,17}$.

Nesta edição, os autores do Principialismo passaram a incorporar a Teoria da Moralidade Comum. Esta teoria, que já havia dado origem ao princípio da não-maleficência, passou a ser a própria fundamentação do Principialismo, o qual sempre foi muito criticado por não ter uma teoria própria, ou, ao menos, uma teoria que conseguisse reunir seus quatro princípios de maneira coerente ${ }^{15}$.

A teoria da moralidade comum proposta no Principialismo por B\&C compreende um conjunto básico de normas morais racionais e socialmente estáveis de certo e errado, sendo tão amplamente aceita e difundida que forma uma verdadeira "instituição social"18. Já a Teoria da Moralidade Comum especificamente desenvolvida por Gert e Clouser (dentre outros autores que também trabalharam esta teoria), consiste em uma tentativa de se explicar doutrinariamente este referencial ${ }^{7}$. Segundo estes autores, as normas morais da moralidade comum começam a ser aprendidas logo após o nascimento; ao longo de suas vidas, as pessoas crescem aprendendo-as, assim como aprendendo a selecioná-las de acordo com os grupos morais a que pertencem ${ }^{18}$.

Por óbvio, a prática bioética muda radicalmente de cultura para cultura, assim como de tempos em tempos, já que não é estática, pois é metaeticamente relativa, respeitando os pluralismos das diferentes culturas e nações $^{19,20,21}$. Isso exige que a análise dos conflitos morais seja contextualizada. Impor a visão moral de uma cultura ou nação politicamente mais forte a outra menos aquinhoada, não consiste em um processo de contextualização, mas mera importação acrítica de conhecimento, o que é denominado de imperialismo moral ${ }^{20}$. 
Diante disso, por certo, a valorização do Princípio da Justiça ocorrerá em maior grau nos países periféricos, onde as desigualdades sociais são mais latentes e problemas cruciais como saneamento básico e outros da mesma importância sanitária, ainda não foram resolvidos. Dos quatro princípios trabalhados pelo Principialismo, este é o mais afeto às questões voltadas ao público e ao coletivo.

No Principialismo, a principal teoria de justiça utilizada foi a de Rawls, o qual emperga o que chama de "véu da ignorância", segundo o próprio, fundamental para a caracterização das partes de um conflito como moralmente livres, iguais e providas de desinteresse mútuo ${ }^{22}$. Contudo, outras teorias começaram a ser invocadas por B\&C ao longo de sua obra, os quais também gradualmente passaram a defender a incapacidade de uma única teoria lidar com todos os problemas que constantemente emergem no campo da saúde.

Rawls parte do pressuposto de que vivemos em sociedades complexas, onde não se deveria apelar a um conjunto de valores compartilhados (a exemplo da moralidade comum) como forma de solução dos conflitos. Assim, um dos maiores problemas do(s) princípio(s) da justiça é justamente encontrar princípio(s) de validade geral que possibilite $(m)$ a distribuição de direitos e de deveres de forma a ser(em) racionalmente aceita(os) por indivíduos morais e racionais $^{22}$.

Em tempos nos quais as desigualdades tomadas como relevantes não residem apenas nas diferentes moralidades, mas também no fato de poder, ou não, pagar e ter acesso a novas tecnologias, acabaram sendo incluídos na pauta bioética internacional novas categorias como vulnerabilidade, exploração, discriminação e a própria comercialização da saúde, consubstanciada na capacidade para pagar como requisito para seu acesso ${ }^{23}$.

Além destas, destacam-se outras aqui trabalhadas por sua constante presença ao longo das sete edições da obra de B\&C, como a saúde sendo tratada como um bem, e não um direito; a conceituação e a delimitação de mínimo existencial; a confidencialidade; a privacidade; o bem-estar; a 
equidade; os critérios de seleção de pacientes para tratamentos; os critérios de alocação de recursos em saúde; o princípio da necessidade; a questão das pesquisas clínicas; a justa oportunidade; a justiça distributiva; a prevenção.

Diante de tudo isso, o contexto internacional da bioética passou a exigir um olhar para além dos quatro princípios propostos por B\&C. Nesse contexto, surgiram várias outras propostas epistemológicas para a bioética, priorizando políticas públicas e tomadas de decisão que privilegiassem as questões sanitárias públicas e coletivas ${ }^{24}$.

Todo este quadro se refletiu na obra de B\&C, onde os autores não conseguiram maquiar sua constante busca por uma teoria de base do Principialismo. Por outro lado, aos olhos críticos dos autores dos países periféricos, o Princípio da Justiça, na proposta de B\&C necessita passar a ser melhor estudado no sentido de sua aplicabilidade prática - ou não - à proporcionar respostas adequadas às questões sociais verificadas nos países periféricos.

No presente estudo, em que se analisou as mudanças ocorridas na obra de B\&C, em especial, a incorporação da Teoria da Moralidade Comum e a transformação no modo de trabalhar o princípio da Justiça, percebeu-se uma constante tentativa de resposta às críticas recebidas. Daí, a importância de se conhecer este histórico de críticas para que se possa também compreender as consequentes mutações do Principialismo que, apesar das considerações já apontadas, ainda continua a ser um dos principais referenciais da Bioética.

As duas vertentes de análise aqui escolhidas, "Teoria da Moralidade Comum" e "Princípio da Justiça", se justificam pelo fato de a primeira, hoje, representar a própria fundamentação do Principialismo, ou seja, sua base estrutural; a segunda, por sua vez, representa um dos quatro princípios da obra, o qual foi deixado em uma espécie de segundo plano nela e é o mais afeto às questões latinoamericanas e dos demais países periféricos. Ademais, são dois dos mais criticados aspectos do Principialismo. 


\section{BREVE HISTÓRICO DO PROCESSO DE CRIAÇÃO, DIFUSÃO E CONSOLIDAÇÃO DO PRINCIPIALISMO}

A palavra "Bioética", em 1971, foi delineada por Van Ressenlaer Potter, da Universidade de Wisconsin (Estados Unidos), na obra "Bioethics: bridge to the future" (Bioética: ponte para o futuro) ${ }^{4}$. Pouco depois, esta palavra também passou a ser utilizada por Andre Hellegers, do Instituto Kennedy de Ética Universidade de Baltimore/Georgetown, que, contudo, Ihe dava conotação estritamente biomédica - diferentemente de Potter, que Ihe dava uma conotação mais ampla ${ }^{25}$.

Segundo Abel, Hellegers não teve conhecimento prévio do neologismo de Potter ou, se teve, não o utilizou de forma consciente ${ }^{25}$. Certo é que ambos o usaram com significações variadas. Potter atribuiu-lhe um sentido ambiental, como uma "ciência da sobrevivência"; enquanto Hellegers o restringiu a uma ética das ciências da vida, particularmente considerando sua vertente humana ${ }^{5}$.

Atualmente, com mais de 40 anos de existência, a Bioética, já consolidada como uma disciplina passou por quatro momentos historicamente distintos: sua fundação (a partir dos anos 1970), sua expansão e consolidação (anos 80 e início dos 90); sua revisão crítica (a partir da metade dos anos 90); e sua ampliação conceitual (até os dias atuais) ${ }^{5}$.

A Bioética foi um dos campos da Ética Aplicada que mais avançou ao longo dos últimos anos. Seu estudo, sem se preocupar com a distinção essencial entre ética e moral, partiu de afirmações enraizadas na tradição filosófica, quase sempre tomadas genericamente como "princípios morais". Estes regulam a vida em sociedade, prevenindo ou limitando os conflitos de diferença, hostilidade e recursos escassos, dentre outros ${ }^{5}$. 
Nesse contexto de formação do neologismo "Bioética", importantes casos de abusos nas pesquisas científicas nos Estados Unidos ocorriam ou estavam em desenvolvimento, sendo divulgados por Beecher em seu artigo "Ethics and clinical research" (Ética e pesquisa clínica), publicado em $1966^{26}$. Dois dentre os 22 casos denunciados por Beecher se destacam. Em 1963, no Jewish Chronic Disease Hospital (Hospital Israelita de Doenças Crônicas), de Nova York, células cancerosas vivas foram injetadas em idosos doentes. Nos mesmos moldes, entre 1950 e 1970, na Willowbrook State School (Escola Estatal de Willowbrook), também de Nova York, crianças deficientes mentais foram infectadas propositalmente com o vírus da hepatite ${ }^{26}$.

Outro caso paralelo que ganhou destaque e que foi denunciado pela própria comunidade científica, ocorrido desde os anos 1930, mas somente suspensa após sua divulgação pública em 1972, foi o que ficou conhecido como Caso Tuskegee. Na região do Alabama, sul dos Estados Unidos, cerca de 400 pessoas afrodescendentes com sífilis foram deixadas sem tratamento para a realização de pesquisa sobre o curso natural da doença - mesmo após o início do uso da penicilina em larga escala, o que se deu em $1940^{3}$.

Como reação a tais escândalos, o governo estadunidense constituiu, em 1974, a National Commission for the Protection of Human Subjects of Biomedical and Behavioral Research (Comissão Nacional para a Proteção dos Sujeitos nas Pesquisas Biomédicas e Comportamentais). Esta Comissão tinha como objetivo estudar e desenvolver um documento que contivesse os princípios éticos básicos que deveriam nortear a experimentação em seres humanos a partir de então. Após quatro anos, em 1978, ela publicou o documento que ficou conhecido como Relatório Belmont (Belmont Report), o qual continha três princípios éticos básicos: o do respeito pelas pessoas, o da beneficência e o da justiça ${ }^{2,3}$.

Neste Relatório, em especial, o princípio da beneficência era composto por duas regras: a de "não causar dano" e a de "maximizar benefícios e minimizar possíveis riscos" ${ }^{2}$. Até neste momento, não havia ainda a distinção 
entre o princípio da beneficência e o da não-maleficência, existindo apenas o primeiro, que englobava os ideais hoje contidos no segundo.

É importante registrar que todos estes princípios, muito antes de se pensar em Ética em Pesquisa, ou mesmo em Bioética, já haviam sido, no passado, trabalhados por diferentes autores. Ainda em 1930, uma das suas principais inspirações iniciais foi delineada por Ross, com seus deveres prima facie de beneficência, de não-maleficência e de justiça ${ }^{9}$. Na mesma obra, Ross também analisou preceitos que considerava fundamentais em ética: o certo ("the right"), o bom ("the good") e o moralmente bom ("the morally good"). Trabalhou o conceito de dever prima facie (posteriormente utilizado como método de aplicação prática dos princípios do Principialismo), o qual consiste em uma obrigação que se deveria cumprir em um primeiro plano, ao menos que entre em conflito, em dada situação, com outro dever moral de igual ou de maior importância ${ }^{9}$.

Cerca de 30 anos depois (1963), outra de suas influências foi proposta por Frankena, com relação aos princípios da beneficência e da justiça. Em uma série de ensaios, o autor definiu beneficência como "the greatest possible balance of good over evil" ("a melhor possível ponderação do bem sobre o mal") e levantou a tese de que existiriam diversos tipos de justiça, o que impossibilitaria se definir justiça de uma maneira genérica, sem saber de qual exatamente estaria se tratando. Além disso, trabalhou temas como valores morais e utilitarismo ${ }^{8}$.

No ano 1981, Veatch propôs um modelo contratualista de Bioética, por meio da edição do livro "A Theory of Medical Ethics" (Uma Teoria de Ética Médica), apresentando uma espécie de triplo contrato (por ter três níveis): na sociedade, acerca dos princípios que orientam a relação médico-paciente; entre médicos e sociedade; e entre médicos e pacientes. Em seu modelo, sete princípios foram propostos: beneficência, não-maleficência, autonomia, cumprimento de promessas (fidelidade), dizer a verdade (honestidade), evitar matar e justiça ${ }^{27}$. 
Em 1986, Engelhardt publicou o livro "The Foundations of Bioethics" (traduzido para o português, em 1998, como "Fundamentos da Bioética"), trabalhando temas como o princípio da autonomia e o direito ao consentimento, o princípio da beneficência, o pluralismo moral e a teoria dos amigos e estranhos morais ${ }^{28,29}$.

Em 1998, Jonsen publicou o livro "The Birth of Bioethics" ("O Nascimento da Bioética"), onde repassa o histórico da Ética Médica, destacando o papel da American Medical Association (Associação Médica Americana) neste processo e relatando trabalhos que datam ainda do início do século 19 - como o do médico inglês Thomas Percival (de 1803). O autor também escolhe o ano de 1987 como um marco ao que hoje conhecemos como Bioética, já que, com o advento da SIDA (Síndrome da Imunodeficiência Adquirida), diversas novas questões éticas eclodiram ${ }^{30}$.

Um ano depois da conclusão do Relatório Belmont, em 1979, B\&C (do Instituto Kennedy de Ética - Universidade de Baltimore/Georgetown), publicaram o livro "Principles of Biomedical Ethics (Princípios de Ética Biomédica)", contendo quatros princípios já aqui citados, mas agora de forma especialmente dedicada ao tema da Ética Biomédica ${ }^{31}$.

Mesmo em meio a estas (além de outras propostas) de solução dos conflitos morais, foi o modelo da obra de B\&C que conquistou maior popularidade e acabou ganhando outros nomes como "abordagem dos quatro princípios", "Principialismo" ou "Princípios de Georgetown" (em referência à sede da universidade que abriga o Instituto Kennedy de Ética, onde B\&C trabalham).

Especificamente sobre o termo "Principialismo", é importante se fazer uma observação, já que Childress, em desacordo com a literatura científica bioética, prefere utilizá-lo como uma referência a qualquer modelo que utilize princípios em sua abordagem ética - e não exclusivamente ao modelo proposto em sua obra conjunta com Beauchamp. Nas palavras do próprio autor: "Eu vou utilizar [...] o termo principialismo para me referir a várias abordagens princípio- 
orientadas" ("I will use [...] the term principlism to refer to various principlesoriented approaches") ${ }^{1}$.

Childress, ao lado de Beauchamp, desenvolveu um modelo de solução prática dos conflitos morais, composto por quatro princípios: beneficência, justiça, autonomia e não-maleficência. Mas como já foi dito anteriormente, os princípios da beneficência e da justiça foram primeiramente trabalhados por Ross $(1930)^{9}$, posteriormente, também por Frankena (1963), bem como faziam parte também do rol estabelecido pelo Relatório Belmont (1978) 2,8 . Mais um princípio componente do Principialismo, o do respeito pela autonomia (ou simplesmente autonomia), também foi oriundo do Relatório Belmont, mas agora com uma nova roupagem para o que inicialmente fora denominado de "princípio do respeito pelas pessoas". O princípio da não-maleficência, por sua vez, era o terceiro dos três deveres prima facie já desenvolvidos por Ross.

Como se pode perceber, o Principialismo é composto pelos deveres prima facie de não-maleficência e de justiça de Ross (1930), pelo princípio da beneficência de Ross (1930) e de Frankena (1963) e pelos princípios da justiça e do respeito pelas pessoas (autonomia) de Frankena (1963) ${ }^{8,9}$. Também seria correto afirmar que o Principialismo possui três de seus quatro pilares calcados no Relatório Belmont, ou seja, 3/4 de sua reflexão ética foi baseada em um documento criado especialmente para regulamentar a ética nas pesquisas com seres humanos ${ }^{3}$.

Estas foram algumas razões para que este Principialismo, a partir dos anos 1990, fosse criticado por não ser uma teoria propriamente dita, por não ter um Princípio da Justiça capaz de lidar com os problemas sociais do dia-a-dia (em especial dos países periféricos) e por não ser suficiente para resolver a maioria dos conflitos éticos que a Bioética passou a abarcar nos mais recentes $\operatorname{anos}^{13,14}$.

Ressalta-se que, segundo seus próprios autores, apesar de não ter sido concebido como uma verdadeira teoria, com o passar do tempo este sistema de princípios dedicados especificamente à Ética Biomédica ganhou grande 
popularidade, inclusive internacionalmente, o que fez com que a comunidade científica passasse a considerá-lo como se uma teoria fosse - e a criticá-lo da mesma forma ${ }^{13,14,15}$.

De fato, o Principialismo nunca refletiu uma Bioética ampla e globalizada, mas tem como base uma fundamentação anglo-saxônica, com forte conotação individualista, cuja sustentação repousa preferencialmente na autonomia dos sujeitos individuais. Talvez esta seja a chave do questionamento sobre o Principialismo não ser adequado para tratar de questões voltadas ao universo dos países em desenvolvimento (ou "periféricos") de modo geral. Assim, muitas das tradicionais críticas ao Principialismo seriam tão somente reações a se estar importando acriticamente uma teoria estrangeira, a qual confere preponderância ao princípio que melhor Ihe veste ${ }^{32}$.

Talvez, a dificuldade de aplicação do Principialismo ao contexto de países periféricos seja apenas uma consequência de sua falta de contextualização ${ }^{32}$. Culturas anglo-saxônicas, como a estadunidense, sofreram forte influência do individualismo protestante. Consequentemente, o princípio da autonomia, de forma natural, acabou tendo sua importância maximizada na prática $^{33}$. Nos Estados Unidos, a colonização foi feita por protestantes, cuja religião era influenciada pelo ideário da predestinação calvinista. Segundo Calvino, Deus não cria todos em uma mesma condição e estado, mas ordena a uns a vida eterna e a outros a perpétua condenação ${ }^{33}$. Essa ideia se baseia no princípio da onisciência de Deus, incorporado pela classe burguesa da localidade - até hoje, justificando o lucro e a riqueza advindos do esforço como evidências do recebimento de graça divina ${ }^{33}$.

Além de fatores religiosos, o pensamento liberal exerceu forte influência sobre a moral estadunidense, que considera o indivíduo como essencialmente o proprietário de sua própria pessoa e de suas escolhas. Nele, a essência humana seria livre da dependência das vontades alheias, havendo liberdade no exercício da posse. O direito e o poder seriam materializados no contrato expresso pela livre manifestação da vontade dos indivíduos em geral ${ }^{34}$. 
De outra monta, nas sociedades latinas (como a brasileira), culturalmente católicas, o sentimento de alteridade, de praticar o bem (beneficência), costuma ser mais exacerbado ${ }^{33}$. Diferentemente do que aconteceu nos Estados Unidos, a colonização latina foi promovida por dois tipos de ação: uma militar, que se baseava na exploração de metais preciosos para sustentar as guerras na Europa; e outra religiosa, que buscava a conversão e a salvação da população indígena - ambas subservientes à fé ${ }^{35}$.

A ideia de catolicismo transmitida aos colonizados ressaltava a "perfeição da caridade", se materializando na solidariedade, na compaixão e na misericórdia. O "espírito de pobreza evangélica" se fundamentava no sentido de que o "Reino de Deus" pertenceria aos "menos favorecidos", e não aos materialmente afortunados. Essa abordagem da fé deu origem a uma espécie de ética do compromisso historicamente originada pela perspectiva latina de preocupar-se também com "o outro", o que frontalmente confronta com a subjetividade e o individualismo protestante ${ }^{35}$.

Os próprios B\&C afirmam que seus princípios não constituem uma teoria moral geral. Importante relembrar que o Principialismo foi criado nos Estados Unidos e especialmente para resolver problemas de cunho biomédico estadunidenses. Somente esta afirmação já impediria sua mera importação de maneira acrítica ${ }^{32}$.

O Principialismo, na medida em que acabou sendo popularizado como a "cara da Bioética" a partir do final dos anos 80 , foi um dos responsáveis por reduzir a concepção potteriana original de Bioética, dando origem à maximização do tema da autonomia nas questões biomédicas de forma a torná-lo um verdadeiro superprincípio, se sobrepondo e/ou influenciando a aplicação dos demais ${ }^{12}$.

Segundo Fox, o que houve na década de 1990 foi uma verdadeira "bioetização" da medicina estadunidense. Isso ensejou até o surgimento de um programa de computador chamado "Dr. Ethics", o qual dava acesso ao usuário 
a uma larga coleção de códigos de ética médica ${ }^{14}$. Como consequência, a visão individualista e preferencialmente autonomista estadunidense passou a ser aceita como a exclusiva vertente de solução dos conflitos éticos no campo biomédico. Assim, esta foi a concepção que acabou divulgando e consolidando a Bioética internacionalmente ${ }^{1,20}$.

A partir dos anos 1990, vozes discordantes com relação à hegemonia dos princípios de Georgetown começaram a surgir ${ }^{13}$. Ainda em 1990, os autores estadunidenses, Clouser e Gert publicaram o artigo "A critique of Principlism" ("Uma crítica ao Principialismo") - talvez até hoje o principal texto de referência crítica ao Principialismo ${ }^{6}$. Esses dois autores foram os primeiros a chamar a atenção para o fato de que os princípios do Principialismo não estão apresentados de modo sistemático e coerente, de modo a constituir uma teoria propriamente dita. Como consequência, segundo eles, pode haver falhas na solução dos conflitos entre os diferentes princípios ou entre este e regras deles derivadas ${ }^{6}$.

Percebendo também que a proposta de B\&C consistia um amálgama de teorias morais já consagradas, afirmaram que seus princípios propostos não poderiam ser verdadeiros guias para ações morais, mas apenas atalhos às próprias teorias de origem, ou seja, meros "check-lists" morais. Foi neste emblemático artigo que as denominações "Principialismo" e "Mantra de Georgetown" (referente ao que chamaram de "ritual de encantamento produzido pelos mesmos), surgiram ${ }^{6}$.

Alguns anos depois, em 1997, novas críticas foram tecidas por Gert e Clouser, agora, acompanhados de Culver, na publicação do capítulo "Principlism" ("Principialismo"), no livro "Bioethics: a return to fundamentals" ("Bioética: um retorno a seus fundamentos") ${ }^{36}$. Obra que, em 2006, foi revisada por seus autores, culminando na publicação do livro: "Bioethics: a systematic approach" ("Bioética: uma abordagem sistemática") ${ }^{37}$. Em novo capítulo dedicado ao Principialismo, discorrem sobre as diferenças entre a abordagem dos quatro princípios de Georgetown e a Teoria da Moralidade Comum, dando 
explicações mais detalhadas sobre as críticas anteriormente tecidas por eles em outros trabalhos científicos ${ }^{37}$.

Ainda nos anos 90 mais precisamente em 1994, críticas da Europa também foram publicadas. Em especial, destacaram-se duas. Primeiramente, as de ten Have, no capítulo de livro "Principlism: a western european appraisal" (“Principialismo: uma concepção da Europa Ocidental”), onde o autor defendeu que o modelo dominante de Bioética (referindo-se ao Principialismo) foi construído exclusivamente sobre um contexto particular (o estadunidense), o qual pregaria o "imperialismo do universal" - uma verdadeira universalização, uma imposição deste ponto de vista para aqueles que dele não compartilham ${ }^{38}$, prática que, na América Latina, costuma-se chamar de "imperialismo moral".

Um ano depois (1995), Holm publicou o artigo "Not just autonomy - the principles of american biomedical ethics" ("Não apenas autonomia - os princípios da ética biomédica americana") ${ }^{11}$. O referido texto apontou a falta de consistência teórica para os processos de determinação e especificação de regras, problematizando o fato de que o Principialismo fundamentava-se estritamente na moralidade comum anglo-saxônica, e que, assim, não poderia ser transferido para outros contextos culturais, já que advindo de uma visão moral particular voltada à supremacia do individual sobre o coletivo ${ }^{11}$.

No mesmo ano (1995), Clouser, agora sem os co-autores da Teoria da Moralidade Comum e das críticas ao Principialismo, publicou o artigo "Common morality as an alternative to Principlism" ("Moralidade comum como uma alternativa ao Principialismo"), questionando a espécie de segundo plano em que o princípio da justiça havia sido deixado na obra ${ }^{7}$.

Veatch, que já havia proposto um modelo próprio contratualista de Bioética em 1999, publicou o artigo "The foundations of Bioethics" ("Os fundamentos da Bioética") levantando questões sobre relativismo e universalismo, onde tratou da necessidade de uma teoria das virtudes e sobre a necessidade de especificação dos princípios no Principialismo ${ }^{19}$. 
Holm, novamente, em 2002, publicou um texto de apresentação e análise à $5^{\mathrm{a}}$. edição do livro de B\&C ("Principles of Biomedical Ethics, 5th ed." "Princípios de Ética Biomédica, $5^{\text {a }}$ ed."), no qual demonstra que houve mudança de entendimento dos seus autores sobre o que seria moralidade comum $^{39}$. Assim, como Luna o fez posteriormente em 2008, Holm relatou que a definição passou de um "rol de normas socialmente sancionadas" ("a set of socially sanctioned norms") a um "rol de normas que todas as pessoas moralmente comprometidas compartilham" ("the set of norms that all morally serious persons share") ${ }^{15,39}$.

Em 2002, De Grazia publicou o artigo "Moving forward in bioethical theory: theories, cases and specified principlism" ("Indo adiante em teoria bioética: teorias, casos e princípios especificados"), destacando a existência de falta de fundamentação no Principialismo, assim como a ausência de um método claro de aplicação dos princípios ${ }^{40}$. Um ano depois (2003), o mesmo autor publicou o artigo "Common morality, coherence, and the Principles of Biomedical Ethics" ("Moralidade comum, coerência, e os Princípios de Ética Biomédica"), em que comenta sobre a falta do instituto da coerência na obra de B\&C e sobre o uso da moralidade comum como fundamentação do Principialismo ${ }^{41}$.

No ano 2003, mais dois importantes artigos foram publicados no contexto aqui analisado. Beauchamp foi autor do "A defense of the common morality" ("Uma defesa da moralidade comum"), esclarecendo que adotou um conceito metaético de moralidade comum no Principialismo, uma vez que todas as pessoas seriam capazes de compartilhar os mesmos preceitos morais, desde que em níveis mais fundamentais ${ }^{42}$. O outro texto deste ano foi publicado por Brand-Ballard com o artigo "Consistency, common morality, and reflective equilibrium" ("Consistência, moralidade comum e equilíbrio reflexivo"), onde trata da controvérsia entre descritivistas e principialistas. Segundo ele, os primeiros adotariam a Teoria da Moralidade Comum como um sistema em que até mesmo as exceções nas aplicações dos princípios encontram amparo metodológico. Já os segundos acreditariam possuir maior flexibilidade na aplicação dos princípios, o que poderia levar pessoas diferentes a conclusões 
diferentes, mas com maior capacidade de solução nos casos mais complexos $^{43}$.

Em 2010, De Grazia e Beauchamp, publicaram o artigo "Philosophy: ethical principles and common morality" ("Filosofia: princípios éticos e moralidade comum"), onde reafirmaram as críticas recebidas pelo Principialismo, mas defendendo que existe uma relação entre elas e as críticas que os princípios em geral também possuem ${ }^{44}$.

Mais recentemente, em 2011, os europeus Karlsen e Solbakk publicaram um artigo com o título "A waste of time: the problem of common morality in principles of biomedical ethics" ("Uma perda de tempo: o problema da moralidade comum nos princípios da ética biomédica"). Nele, criticam o fato de a Teoria da Moralidade Comum ter passado a ser a própria fundamentação do Principialismo, além reforçar as razões de não considerarem o Principialismo como uma proposta universal ${ }^{45}$.

No mesmo ano (2011), Rauprich e Vollmann, com o artigo "30 Years Principles of biomedical ethics: introduction to a symposium on the 6th edition of Tom L Beauchamp and James F Childress' seminal work" ("Princípios de ética biomédica nos seus 30 anos: introdução a um simpósio sobre a $6^{a}$. edição do trabalho inaugural de Tom L Beauchamp e James F Childress"), apresentaram o que seria um simpósio sobre a $6^{\mathrm{a}}$. edição da obra de B\&C que resultou na publicação de diversos artigos na revista Journal of Medical Ethics $^{46}$.

Nesta mesma edição (2011), Rauprich publicou "Specification and other methods for determining morally relevant facts" ("Especificacão e outros métodos para determinar fatos moralmente relevantes"), discorrendo sobre a especificação como ferramenta de aplicação contextualizada dos princípios ${ }^{47}$. Ainda em 2011, Gordon, Rauprich e Vollmann escreveram "Applying the fourprinciple approach" ("Aplicando a abordagem dos quatro princípios"), ressaltando a facilidade de aplicação do Principialismo frente ao que seria a prática da Teoria da Moralidade Comum. Além disso, defenderam a moralidade 
comum enquanto um superprincípio, guiando e orientando a aplicação concreta dos demais ${ }^{48}$.

Como resposta, Beauchamp lançou o artigo "Making Principlism practical: a commentary on Gordon, Rauprich, and Vollmann" ("Fazendo o Principialismo prático: um comentário sobre Gordon, Rauprich, e Vollmann"), onde tece considerações sobre as criticas dos autores Gordon, Rauprich, e Vollmann, além de levantar a tese de que as críticas tecidas ao seu Principialismo não passariam de críticas aplicáveis a qualquer outra teoria ${ }^{49}$.

Herissone-Kelly, na mesma edição aqui comentada em 2011, assentou em seu artigo "Determining the common morality's norms in the sixth edition of Principles of Biomedical Ethics" ("Determinando as normas da moralidade comum na $6^{\mathrm{a}}$. edição dos Princípios de Ética Biomédica"), sobre a definição adotada por de B\&C do que seria moralidade comum, já que entendem serem normas compartilhadas por tão somente pessoas "moralmente comprometidas". Além disso, discorre sobre os métodos empíricos adotados pelos autores para determinar quais seriam estas normas ${ }^{50}$.

A postura dos bioeticistas da América Latina, de modo geral, não foi diferente. As primeiras observações foram de Garrafa, em 1994, no artigo "Bioética, saúde e cidadania", em que propôs a ampliação do paradigma da Bioética para as situações persistentes (com temas como fome, miséria e racismo) e para as situações emergentes dos últimos 30/40 anos (com temas relacionados às práticas biotecnológicas (os transplantes, o genoma humano, a clonagem.... $)^{51}$.

Dois anos depois (1996), mais críticas provieram de Lepargneur, no artigo "Força e fraqueza dos princípios da Bioética", no sentido de que nenhum princípio seria capaz de esclarecer, sozinho, uma orientação ética. O problema do agir moral seria uma questão de escolha entre princípios que aconselham vias diversas - até mesmo opostas. Para ele, a avaliação ética deveria retomar o fio da prudência trabalhada por autores como Tomás de Aquino e Aristóteles, sugerindo uma espécie de "Bioética das Virtudes"52. 
Em 1998, Pessini e Barchifontaine publicaram o capítulo de livro "Bioética: do Principialismo à busca de uma perspectiva latino-americana", onde criticam o Principialismo como uma Bioética "made in USA" ("fabricada nos Estados Unidos") e defendem que os problemas latino-americanos, mais relacionados aos princípios da justiça, da equidade e da alocação de recursos em saúde, são pouco passíveis de solução pelos quatro princípios de Georgetown ${ }^{53}$.

No texto de Garrafa et al, de 1999, "Bioethical language and its dialects and idiolects" (O idioma bioético e seus dialetos e idioletos), encontra-se uma analogia entre Bioética, ou "Bioéticas", "ao idioma, seus dialetos e idioletos" percebendo-se a dificuldade de se contextualizar e aplicar uma proposta construída "sobre" e "para" uma realidade diversa ${ }^{54}$.

Nesta mesma linha de reflexão, começaram a surgir críticas em relação ao imperialismo ético promovido pelos países centrais do Hemisfério Norte, no que tange à Ética em Pesquisa, promovidas por Garrafa e Prado no artigo "Mudanças na Declaração de Helsinki: fundamentalismo econômico, imperialismo ético e controle social" (2001) ${ }^{55}$. No mesmo período é apresentada a Bioética de Intervenção como uma alternativa ao centralismo conceitual nortista, por meio das considerações de Garrafa e Porto (2003) no artigo "Intervention Bioethics: a proposal for peripheral countries in a context of power and injustice" ("Bioética de Intervenção: uma proposta para países periféricos em um contexto de poder e injustiça") e de Garrafa (2005) no artigo "Da bioética de princípios a uma bioética interventiva"12,56.

Neles, apresentou-se uma crítica afirmativa contra o referencial principialista, já que este seria insuficiente para analisar os macroproblemas éticos persistentes verificados na realidade concreta dos países periféricos ${ }^{12,56}$. Seus autores introduziram o tema da Bioética de Intervenção (inicialmente - já em 1998 - chamada de Hard Bioethics, que seria traduzido como "Bioética Dura") como uma ferramenta de discussão mais politicamente engajada do que a Bioética Principialista costuma ser ${ }^{12,56}$. 
Serodio, tal qual Garrafa et al haviam salientado em 1999, no artigo "Revisitando o Principialismo: aplicações e insuficiências na abordagem dos problemas bioéticos nacionais" (2008), chamou a atenção novamente para a questão da importação acrítica de conceitos e da consequente necessidade de contextualização dos princípios à nossa realidade - o que se faria por meio do método da especificação, ou seja, da concretização dos institutos que a ele pertencem $^{32,54}$.

Luna, já citada, ainda em 2008, publicou "Planteos clásicos y teoria de los princípios" ("Proposições clássicas e a teoria dos princípios"), capítulo de livro no qual foram colecionadas as diversas criticas até então tecidas ao Principialismo, onde ressalta ainda a diferença substancial constatada entre a $3^{\mathrm{a}}$ e $4^{\mathrm{a}}$ edições da obra de $B \& \mathrm{C}^{15}$.

Por fim, Garrafa (2012) publicou o artigo "Ampliação e politização do conceito internacional de bioética", em que realizou um breve histórico até a recente promulgação da Declaração Universal sobre Bioética e Direitos Humanos da Unesco, também propondo mudanças teóricas e metodológicas na Bioética com vistas a poder melhor trabalhar questões relacionadas às persistentes desigualdades sociais constatadas no mundo conrtemporâneo ${ }^{57}$.

Como se pode perceber, inúmeras críticas ao Principialismo surgiram de diversas partes do mundo, principalmente dos próprios Estados Unidos, mas também da Europa e da América-Latina. Cada uma das regiões produziu críticas sob seus diferentes enfoques ${ }^{13}$.

A seguir, apresenta-se um quadro-resumo da cronologia das edições do livro "Principles of Biomedical Ethics" ("Princípios de Ética Biomédica”), assim como de alguns dos principais artigos e capítulos de livro publicados com diferentes críticas à obra de B\&C. 
Quadro 1. Quadro-resumo da cronologia das edições do livro Principles of Biomedical Ethics e de alguns dos principais artigos/capítulos de livro com críticas à obra

\begin{tabular}{|c|c|c|}
\hline ANO & PUBLICAÇÃO & ORIGEM \\
\hline 1979 & \multicolumn{2}{|l|}{$1^{a}$. EDIÇÃO DO LIVRO PRINCIPLES OF BIOMEDICAL ETHICS } \\
\hline 1983 & \multicolumn{2}{|l|}{$2^{a}$. EDIÇÃO DO LIVRO PRINCIPLES OF BIOMEDICAL ETHICS } \\
\hline 1989 & \multicolumn{2}{|l|}{$3^{a}$. EDIÇÃO DO LIVRO PRINCIPLES OF BIOMEDICAL ETHICS } \\
\hline 1990 & $\begin{array}{l}\text { Clouser KD, Gert B. A critique of principlism. The Journal of Medicine and } \\
\text { Philosophy. } 1990 ; 15 \text { (s.n.):219-236. }\end{array}$ & Estados Unidos \\
\hline 1994 & \multicolumn{2}{|l|}{$4^{\mathrm{a}}$. EDIÇÃO DO LIVRO PRINCIPLES OF BIOMEDICAL ETHICS } \\
\hline \multirow[t]{2}{*}{1994} & $\begin{array}{l}\text { Ten Have H. Principlism: a western european appraisal. p. 101-120. In: Du Bose } \\
\text { ER, et al (ed.). A matter of principles? Ferment in U.S. bioethics. Pennsylvania: } \\
\text { Ed. Trinity; 1994. }\end{array}$ & Estados Unidos \\
\hline & $\begin{array}{l}\text { Garrafa V. Bioética, saúde e cidadania. Humanidades (Universidade de Brasília). } \\
\text { 1994; 9(4):342-351. }\end{array}$ & Brasil \\
\hline \multirow[t]{2}{*}{1995} & $\begin{array}{l}\text { Clouser KD. Common morality as an alternative to Principlism. Kennedy Institute } \\
\text { of Ethics Journal. 1995; 5(3):219-236. }\end{array}$ & Estados Unidos \\
\hline & $\begin{array}{l}\text { Holm, S. Not just autonomy - the principles of american biomedical ethics. J Med } \\
\text { Ethics. 1995; } 21 \text { (s.n.):332-338. }\end{array}$ & Noruega \\
\hline 1996 & $\begin{array}{l}\text { Lepargneur H. Força e fraqueza dos princípios da bioética. Bioética. Conselho } \\
\text { Federal de Medicina. 1996; } 4(2): 131-43 \text {. }\end{array}$ & Brasil \\
\hline 1997 & $\begin{array}{l}\text { Gert B, Culver C, Clouser D. Principlism. p. 71-92. In: Bioethics: a return to } \\
\text { fundamentals. New York: Oxford Press; } 1997 .\end{array}$ & Estados Unidos \\
\hline 1998 & $\begin{array}{l}\text { Pessini L, Barchifontaine CP. Bioética: do Principialismo à busca de uma } \\
\text { perspectiva latino-americana. p. 81-96. In: Costa SIF, Garrafa V. Oselka G } \\
\text { (coord.). Iniciação à Bioética. Brasilia: Ed. do CFM; } 1998 \text {. }\end{array}$ & Brasil \\
\hline \multirow[t]{2}{*}{1999} & $\begin{array}{l}\text { Garrafa V, et al. Bioethical language and its dialects and idioletcts. Cadernos de } \\
\text { Saúde Pública. 1999; 15(1):35-42. }\end{array}$ & Brasil \\
\hline & Veatch RM. The foundations of Bioethics. Bioethics. 1999;13(3/4):206 -217. & Estados Unidos \\
\hline 2001 & \multicolumn{2}{|c|}{$5^{\mathrm{a}}$. EDIÇÃO DO LIVRO PRINCIPLES OF BIOMEDICAL ETHICS } \\
\hline 2001 & $\begin{array}{l}\text { Garrafa V. Prado MM. Mudanças na Declaração de Helsinki: fundamentalismo } \\
\text { econômico, imperialismo ético e controle social. Cad. Saúde Pública. 2001; 17(6): } \\
\text { 1489-1496. }\end{array}$ & Brasil \\
\hline 2002 & TRADUÇÃO DA $4^{a}$. EDIÇÃO PARA O PORTUGUÊS & \\
\hline \multirow[t]{2}{*}{2002} & Holm S. Principles of Biomedical Ethics, 5th ed. J Med Ethics. 2002; 28(jun):332. & Nort \\
\hline & $\begin{array}{l}\text { De Grazia D. Moving forward in bioethical theory: theories, cases and specified } \\
\text { principlism. The Journal of Medicine and Philosophy. 2002; (17):511-539. }\end{array}$ & Estados Unidos \\
\hline \multirow[t]{5}{*}{2003} & $\begin{array}{l}\text { Garrafa V, Porto D. Intervention bioethics: a proposal for peripheral countries in a } \\
\text { context of power and injustice. Bioethics. 2003; 17(5-6):399-416. }\end{array}$ & Brasil \\
\hline & $\begin{array}{l}\text { De Grazia D. Common Morality, Coherence, and the Principles of Biomedical } \\
\text { Ethics. Kennedy Institute of Ethics Journal. 2003; 13(3):219-230. }\end{array}$ & Estados Unidos \\
\hline & $\begin{array}{l}\text { Garrafa V, Pessini L. Orgs. Bioética: poder e injustiça. São Paulo: Ed. Loyolla; } \\
2003 .\end{array}$ & Brasil \\
\hline & $\begin{array}{l}\text { Beauchamp TL. A defense of the common morality. Kennedy Institute of Ethics } \\
\text { Journal. 2003; } 13(3): 259-274 \text {. }\end{array}$ & Estados Unidos \\
\hline & $\begin{array}{l}\text { Brand-Ballard J. Consistency, common morality, and reflective equilibrium. } \\
\text { Kennedy Institute of Ethics Journal. 2003; 13(3): 231-258. }\end{array}$ & Estados Unidos \\
\hline \multirow[t]{3}{*}{2005} & $\begin{array}{l}\text { Garrafa V. Da bioética de princípios a uma bioética interventiva. Bioética. } \\
\text { 2005;13(1):125-34. }\end{array}$ & Brasil \\
\hline & $\begin{array}{l}\text { Paris. Unesco - Organização das Nações Unidas para a Educação, Ciência e } \\
\text { Cultura. Declaração Universal sobre Bioética e Direitos Humanos. 33a Sessão da } \\
\text { Conferência Geral da Unesco, } 19 \text { de outubro de } 2005 \text {. Disponivel em } \\
\text { http://unesdoc.unesco.org/images/0014/001461/146180por.pdf. }\end{array}$ & $\begin{array}{l}\text { Comunidade } \\
\text { internacional }\end{array}$ \\
\hline & $\begin{array}{l}\text { Garrafa V, Kottow M, Saada A (coords.). Estatuto epistemológico de la Bioética. } \\
\text { México: Ed. da REDBIOÉTICA; } 2005 \text {. }\end{array}$ & $\begin{array}{l}\text { Comunidade latino- } \\
\text { americana }\end{array}$ \\
\hline \multirow[t]{2}{*}{2006} & $\begin{array}{l}\text { Garrafa V, Kottow M, Saada A (orgs.). Bases Conceituais da Bioética: enfoque } \\
\text { latino-americano. São Paulo: Ed. Gaia; } 2006 .\end{array}$ & $\begin{array}{l}\text { Comunidade latino- } \\
\text { americana } \\
\text { (traduçãa) }\end{array}$ \\
\hline & $\begin{array}{l}\text { Gert B, Culver C, Clouser D. Principlism. p. 99-127. In: Bioethics: a Systematic } \\
\text { Approach. New York: Oxford Press; } 2006 .\end{array}$ & Estados Unidos \\
\hline 2008 & Luna F. Planteos clásicos y teoria de los princípios. p. 23-78. In: Luna F, Salles & \\
\hline
\end{tabular}




\begin{tabular}{|c|c|c|}
\hline & $\begin{array}{l}\text { ALF. Bioética: nuevas reflexiones sobre debates clásicos. Buenos Aires: Ed. } \\
\text { Fondo de Cultura Econômica; } 2008 \text {. }\end{array}$ & $\begin{array}{l}\text { Comunidade latino- } \\
\text { americana }\end{array}$ \\
\hline 2008 & $\begin{array}{l}\text { Serodio A. Revisitando o Principialismo: aplicações e insuficiências na abordagem } \\
\text { dos problemas bioéticos nacionais. Revista Brasileira de Bioética 2008;4(1-2):69- } \\
79 \text {. }\end{array}$ & Brasil \\
\hline 2009 & \multicolumn{2}{|l|}{$6^{\mathrm{a}}$. EDIÇÃO DO LIVRO PRINCIPLES OF BIOMEDICAL ETHICS } \\
\hline 2010 & $\begin{array}{l}\text { De Grazia D, Beauchamp TL. Philosophy: Ethical Principles and Common } \\
\text { Morality. p. 37-53. In: Sugarman J, Sulmasy DP (ed.). Methods in Medical Ethics. } \\
\text { Georgetown: Georgetown University Press; } 2010\end{array}$ & Estados Unidos \\
\hline \multirow[t]{6}{*}{2011} & $\begin{array}{l}\text { Karlsen JR, Solbakk JH. A waste of time: the problem of common morality in } \\
\text { Principles of Biomedical Ethics. J Med Ethics. 2011; 37(10):588-591. }\end{array}$ & Noruega \\
\hline & $\begin{array}{l}\text { Gordon JS, Rauprich O, Vollmann J. Applying the four-principle approach. } \\
\text { Bioethics. 2011; 25(6):293-300. }\end{array}$ & Alemanha \\
\hline & $\begin{array}{l}\text { Beauchamp T. Making Principlism Practical: A Commentary On Gordon, Rauprich, } \\
\text { And Vollmann. Bioethics. 2011; 25(6): 301-303. }\end{array}$ & Estados Unidos \\
\hline & $\begin{array}{l}\text { Rauprich O, Vollmann J. } 30 \text { Years Principles of biomedical ethics: introduction to a } \\
\text { symposium on the 6th edition of Tom L Beauchamp and James F Childress' } \\
\text { seminal work. J Med Ethics. 2011;37(10):582-583. }\end{array}$ & Alemanha \\
\hline & $\begin{array}{l}\text { Rauprich O. Specification and other methods for determining morally relevant } \\
\text { facts. J Med Ethics. 2011; 37(10):592-596. }\end{array}$ & Alemanha \\
\hline & $\begin{array}{l}\text { Herissone-Kelly P. Determining the common morality's norms in the sixth edition } \\
\text { of Principles of Biomedical Ethics. J Med Ethics. 2011; 37(10):584-587. }\end{array}$ & Inglaterra \\
\hline 2012 & $\begin{array}{l}\text { Garrafa V. Ampliação e politização do conceito internacional de bioética. Revista } \\
\text { Bioética (CFM). 2012; } 20 \text { (1):09-20. }\end{array}$ & Brasil \\
\hline 2013 & \multicolumn{2}{|l|}{$7^{a}$. EDIÇÃO DO LIVRO PRINCIPLES OF BIOMEDICAL ETHICS } \\
\hline
\end{tabular}

Dos textos acima elencados, é notável que alguns pontos passaram a ser criticados com maior frequência, por exemplo: a falta de uma teoria própria do Principialismo; o excesso de atenção dada ao princípio da autonomia, em detrimento dos demais, em especial ao da justiça; a aplicação exclusiva do Principialismo a questões de cunho biomédico; as diferentes origens de cada um dos princípios; a incapacidade dos mesmos no enfrentamento aos macroproblemas bioéticos comuns aos países periféricos, e a excessiva discricionariedade no método de aplicação concreta dos princípios ${ }^{13}$.

Alguns eventos também merecem ser citados enquanto marcos históricos da reação ao uso exclusivo do Principialismo como método de solução dos conflitos morais da Bioética. Dentre estes deve-se destacar os congressos mundiais promovidos pela International Association of Bioethics (IAB) acontecidos em Tóquio (1998) e em Brasília (2002), cujos temas demonstraram claramente uma reação em prol da re-globalização da agenda bioética. No Quarto Congresso Mundial de Bioética, organizado em Tóquio Japão (1998), o tema oficial do evento foi "Bioética Global". Este tema remontou aos moldes com que a Bioética teria sido originalmente delineada por 
Potter, ou seja, de concepção ampla e globalizada ${ }^{3}$. Em 2002, no Sexto Congresso Mundial de Bioética, realizado em Brasília - Brasil, o tema oficial do encontro foi "Bioética, Poder e Injustiça". Com a participação de mais de 1.400 acadêmicos de 62 países, este evento ainda deu origem a um livro de mesmo nome, organizado por Garrafa e Pessini (2003), o qual reuniu toda a essência do que fora apresentado no evento ${ }^{3}$.

Reforçando a ideia de incluir outros referenciais teóricos à Bioética, entre os anos 2003 e 2005 a Organização das Nações Unidas para a Educação, a Ciência e a Tecnologia (Unesco) destinou esforços, a partir de seu Comitê de Bioética Internacional (International Bioethics Committee - IBC), na construção do documento público mais importante elaborado neste século sobre Bioética: a Declaração Universal sobre Bioética e Direitos Humanos (Paris - França, $2005)^{58}$. Esta Declaração foi fruto de grande discussão internacional, com a participação de 191 países, inclusive o Brasil. Proclamada na 33a Sessão da Conferência Geral da Unesco, representou um marco na regulação biotecnocientífica e social mundial. Seus 28 artigos, sendo 15 deles destinados especificamente a "princípios", ampliou e redefiniu, definitivamente, a agenda bioética do século $21^{59,60}$.

Contemporaneamente ao processo de elaboração desta declaração, a agenda bioética também foi rediscutida em um seminário em Montevidéu Uruguai (2004), promovido pela Rede Latino-Americana e do Caribe de Bioética da Unesco (Redbioética). Deste, surgiu o livro intitulado "Estatuto epistemológico de la Bioética" na sua edição em espanhol de 2005 tradução para o português, um ano depois (2006) na obra "Bases conceituais da Bioética - enfoque latino-americano" ${ }^{62}$. Nestes livros, diversos autores latinoamericanos estabeleceram o que seria o marco conceitual da Bioética na região.

A partir de todo o contexto acima apresentado, novos referenciais, além dos do Principialismo, passaram a incorporar a pauta bioética mundial, especialmente na América Latina. Percebe-se que toda esta produção acadêmica gerada a partir das críticas ao Principialismo acabou também 
expandindo a Bioética, na medida em que incorporou à sua agenda problemas até então deixados em segundo plano. 


\section{FUNDAMENTAÇÃO TEÓRICA}

\subsection{Teorias morais que fundamentam a obra de B\&C}

Teorias morais são reflexões ou argumentações teóricas que sistematicamente apresentam componentes éticos básicos de modo a formar um corpo integrado de normas e suas justificações morais básicas. Cada uma destas duas possui vantagens e desvantagens. Por esta razão, uma reflexão moral completa deve incluí-las ${ }^{18}$.

Segundo B\&C, o Principialismo em si não constitui uma teoria moral propriamente dita, mas sim um sistema organizado de princípios, o qual apresenta apenas alguns aspectos de uma verdadeira teoria ${ }^{18}$. Os autores defendem que seriam quatro as teorias morais obrigatórias para que se possa realizar um estudo reflexivo sobre a Bioética Principialista: a Utilitarista, a Kantiana, a dos Direitos e a das Virtudes ${ }^{11,18}$. A seguir, estas quatro correntes filosóficas são brevemente descritas, sempre na ótica de B\&C e retiradas da edição mais recente de Principles of Biomedical Ethics.

\subsubsection{A Teoria Utilitarista}

Teorias consequencialistas são aquelas baseadas na ponderação de suas consequências, sejam boas ou más. Nessas teorias, corretos são os atos que produzem os melhores resultados em âmbito impessoalmente global. $O$ maior exemplo delas é a Teoria Utilitarista, baseada exclusivamente no princípio ético da utilidade ${ }^{18}$. O princípio da utilidade, derivado nos escritos originais de Bentham (1748-1832) e de Mill (1806-1873), afirma que se deve sempre dar preferência ao valor positivo sobre o valor negativo ou, no mínimo, o menor valor negativo possível, caso este seja inevitável, na análise dos casos concretos. 
Trata-se, segundo $B \& C$, de um verdadeiro cálculo preferencialmente vantajoso de consequências, à primeira vista, muito convincente ${ }^{18}$. Segundo eles, um ponto a se destacar nessa teoria é o da falta de especificação de quais valores morais seriam considerados impessoalmente positivos. Uma resposta (mas que também geraria incertezas) seria a de que se deve buscar a produção de bens neutros ou intrínsecos - bens valiosos em si mesmos e que toda pessoa racional valorizaria ${ }^{18}$.

Bentham e Mill, utilitaristas hedonistas, concebem o valor positivo em termos de felicidade e de prazer, termos que também geram certo grau de incerteza, pois são amplos e quase sinônimos um do outro, de acordo com os criadores do principialismo, que prosseguem na análise crítica do utilitarismo afirmando que, assim como estas propostas, inúmeras outras foram criadas, contudo, nenhuma capaz de definir universal e claramente o que seria uma consequência positiva ${ }^{18}$.

Daí decorre, sempre segundo B\&C, outro grande problema da Teoria Utilitarista: a "aceitabilidade" das ações. Se não existe um padrão único e universal do que seria uma consequência positiva, a única saída nesta determinação seria partir para as preferências subjetivas dos seres racionais individualmente, caindo-se na questão da necessidade de aceitação desta preferência pelos outros - o que nem sempre ocorrerá ${ }^{18}$.

Por fim, destacam a questão da exacerbação da imparcialidade na busca de resultados positivos, assim como a ausência de sua valoração, independentemente de se buscar justiça na Teoria Utilitarista. Como decorrência disso, por uma questão de princípios, poderia se justificar moralmente distribuições injustas - onde os interesses das maiorias passariam por cima dos das minorias ${ }^{18}$. Esta seja talvez a maior crítica de B\&C à Teoria Utilitarista. 


\subsubsection{A Teoria Kantiana}

Como principal exemplo de teoria deontológica, tem-se a Teoria Kantiana - nome dado à teoria baseada nas ideias de Kant. Ela, assim como as outras teorias deontológicas, tem seu foco no que seria o moralmente correto, se concentrando nas ações, e não nos sujeitos ou em suas consequências $^{18}$. Kant imaginava os seres humanos como criaturas com poderes racionais para resistir ao moralmente incorreto. Acreditava que a moralidade se fundava na razão pura. Para ele, o agir não deveria ser "conforme" obrigação, mas sim "por" obrigação ${ }^{18}$.

No Kantismo não basta que a ação tenha uma consequência positiva; ela deve ter, antes de tudo, uma justificação moralmente correta. A esta justificação dá-se o nome de "máxima da ação". Seja qual for o resultado prático, se a máxima da ação não for moralmente correta, não haverá crédito moral nenhum ${ }^{18}$. Para Kant, toda máxima da ação deve passar por um teste, uma verdadeira "peneira" moral, que ele chama de "imperativo categórico": "Age somente de acordo com a máxima que possas ao mesmo tempo querer que se transforme em lei universal"; "age de tal modo que trate todas as pessoas como um fim, e nunca simplesmente como um meio"; e "age de modo de que tua vontade possa valer sempre ao mesmo tempo como princípio de uma legislação universal"18.

Mas, segundo B\&C a teoria de Kant, tal qual a teoria do Utilitarismo, falha ao tentar proporcionar uma teoria plenamente adequada à vida moral. No caso de obrigações morais conflitantes, por exemplo, o Kantismo, ao considerar todas as obrigações morais como absolutas, torna quase impossível deliberar sobre qual obrigação deve ser realmente levada a fio ${ }^{18}$. Isso porque os absolutismos, ao mesmo tempo em que geram certezas no agir, podem gerar impossibilidades de agir nos casos de conflitos entre eles. Este, segundo os autores mencionados, costuma ser um problema nas teorias morais em geral, pois, de forma prática, ou se tem apenas uma obrigação moral como a única absoluta ou se abre mão do absolutismo para o abstrativismo de todas elas $^{18}$. 


\subsubsection{A Teoria dos Direitos}

A Teoria dos Direitos, baseada no individualismo liberal, foi plenamente incorporada pela tradição legal anglo-americana. Esta teoria cria proteções, por meio de direitos e de suas garantias aos indivíduos pertencentes às sociedades democráticas ${ }^{18}$.

Ter um direito pressupõe a capacidade de exigência de seu cumprimento e a existência de certa obrigação. Esta obrigação pode ser de fazer (ou de se abster de fazer) algo em relação a alguém. A exigência de cumprimento de direitos é essencial à sua materialização. De acordo com B\&C, nos dias atuais, deve ser até mesmo indispensável, já que, nas sociedades democráticas, os interesses individuais quase sempre estão em conflito com os coletivos e/ou institucionais ${ }^{18}$.

Tais direitos costumam ser expressos por meio de regras, as quais costumam ser oriundas de princípios legais e/ou morais, a depender de suas fontes. Independentemente de classificações e da mesma forma que ocorre nas demais teorias, os conflitos de direitos são aqui o ponto-chave de discussão ${ }^{18}$.

Para os autores aqui referenciados, nesta teoria existe grande discussão não apenas sobre qual direito seria absoluto ou prioritário, mas precipuamente se haveria um direito absoluto ou prioritário. Em segundo plano, outro problema se concentra na determinação de quais obrigações estariam relacionadas aos direitos em pauta, pois não existe um rol especificado ${ }^{18}$. E num terceiro plano, após superar-se a delimitação de obrigações, a dificuldade passa a se concentrar na hierarquia dessas obrigações, assim como nas suas execuções por meio de diretrizes de ação. A questão prática não respondida, de acordo com eles, é: haveria como agir em prol de direitos (absolutos ou prioritários) sem agir em detrimento de outros direitos (absolutos ou prioritários) ${ }^{18}$ ?

Por fim, B\&C chamam a atenção para que se deve estar atento ao fato de que discussões baseadas puramente em direitos empobrecem a concepção 
da moralidade nelas envolvidas. Os direitos já concebidos são incapazes de externar os significados morais dos seus motivos, fazendo com que suas discussões fiquem limitadas a planos que não os da fundamentação ${ }^{18}$.

\subsubsection{A Teoria das Virtudes}

B\&C afirmam também que as teorias utilitaristas e algumas kantianas tentaram se basear em apenas um princípio norteador. Apesar de bem estruturadas, esqueceram de fenômenos morais importantes, como o caráter e a virtude. Assim, a Teoria das Virtudes (ou Ética do Caráter) tem como foco não as consequências necessariamente positivas, nem mesmo o agir moral, mas o agente -0 qual deve possuir caráter virtuoso ${ }^{18}$.

Em grego antigo, a areté (traduzida para o português como virtude) significava a excelência do caráter ou o mérito da pessoa. Ainda, podia representar a qualidade da alma ou da inteligência, podendo ser, por exemplo, de espírito serviçal, corajosa, honrosa ou talentosa - dentre outras ${ }^{52}$.

Partindo-se de uma tradição grega aristotélica, com sua tônica concentrada no agente, a virtude é uma disposição que se aperfeiçoa pelo hábito ${ }^{5}$. Por isso, o respeito às virtudes é universalmente admirado. A pessoa que não o possui ou que possui o seu inverso (vícios de virtude) é considerada um deficiente moral ${ }^{42}$.

A virtude é um traço de caráter socialmente valorizado e a virtude moral é um traço de caráter moralmente valorizado. Apesar de, à primeira vista, parecerem muito próximas, a virtude moral não se confunde, ou mesmo se reduz, à virtude social. O simples fato de uma virtude ser socialmente aclamada, não faz com que ela seja uma virtude moral, pois, para tanto, requer que todo um contexto a torne moral, já que se valorará em relação a algo ${ }^{18}$.

Mais precisamente, deve-se acreditar que a virtude é uma disposição que se aperfeiçoa pelo hábito de se agir de acordo com princípios morais ${ }^{5}$. 
Enquanto qualidade do sujeito moral, ela se vincula a uma moral da intenção ${ }^{52}$. Porém, as virtudes não contêm diretrizes, sendo apenas traços de caráter que devem estar presentes na pessoa que vive de acordo com os ditames da moralidade.

De acordo com B\&C, para cada um dos princípios morais existirá sempre uma virtude correspondente. Por exemplo, as virtudes dos quatro princípios do Principialismo são: respeito (correspondente ao princípio da autonomia), não-malevolência (correspondente ao princípio da nãomaleficência), benevolência (correspondente ao princípio da beneficência), e justeza (correspondente ao Princípio da Justiça) ${ }^{18}$.

Segundo o próprio Beauchamp, em um artigo que publicou individualmente alguns anos depois das críticas iniciais, já nos anos 2000, nota-se que, até por serem coisas diversas, virtudes e princípios podem estar presentes na mesma ação. Assim, uma pessoa malevolente de caráter pode agir de forma beneficente, assim como uma pessoa benevolente pode agir de forma maleficente. Trata-se de uma discrepância que pode ocorrer ao se escolher o que seria moralmente mais aceitável (ou não) sem possuir a intenção correspondente ${ }^{42}$.

\subsection{A Teoria da Moralidade Comum em B\&C}

Apesar de não ter sido claramente explicitado por B\&C como sendo uma das teorias éticas de que influenciaram o Principialismo, nem mesmo na atual $7^{a}$. edição (onde o tema foi mais desenvolvido em relação às edições precedentes), é possível afirmar que a Teoria da Moralidade Comum passou a ser utilizada como o principal elemento de fundamentação teórica do Principialismo já que foi assim utilizada, começando a aparecer a partir da $4^{\mathrm{a}}$. edição da obra, o que justifica a sua inclusão neste capítulo e nesta tese.

A moralidade comum, enquanto produto histórico compreende um conjunto básico de normas morais, entendidas pelos autores no sentido de um 
conjunto de regras e princípios morais que compreendem um conjunto racional e socialmente estável de certo e errado, sendo tão amplamente aceitas e difundidas que formam uma verdadeira "instituição social" ${ }^{18}$.

Já a Teoria da Moralidade Comum (a moralidade comum interpretada enquanto uma verdadeira e própria teoria), desenvolvida por Gert e Clouser (dentre outros autores que também trabalharam esta teoria), consiste em uma tentativa de se explicar doutrinariamente o referencial histórico e pré-teórico da moralidade comum ${ }^{7}$. Segundo Karlsen e Solbakk, trata-se de uma teoria que pode ser aplicada a qualquer pessoa independentemente de sua cultura ou tempo ${ }^{45}$.

Esta teoria é de aplicação complexa, possuindo níveis de fundamentação que vão muito além da livre escolha entre princípios e regras morais. Basicamente, de acordo com Gordon, Rauprich e Vollmann consiste no uso concomitante de um critério e de três conjuntos, um de dez regras morais (decálogo), um de dez ideais morais e um de dez feitos morais relevantes, sendo que o critério único, em grau máximo de abstração, serve para determinar quando as exceções às regras seriam justificáveis, em especial nos casos de choque entre estas ${ }^{48}$. Além disso, inclui também, de acordo com $B \& C$, a análise dos traços de caráter universal e positivamente morais (as virtudes), assim como dos vícios de caráter ${ }^{18}$.

Tal qual acontece com outras moralidades, as normas morais da moralidade comum começam a ser aprendidas logo após o nascimento. Todas as pessoas, de todas as culturas, crescem constantemente aprendendo-as. Porém, ao longo da vida, estas pessoas também aprendem a separá-las de acordo com os grupos morais a que pertencem ${ }^{18}$. Apesar desta capacidade de identificar e separar as normas morais que as pessoas em geral possuem, certos entendimentos semelhantes sobre determinadas demandas básicas que costumam atingir a todos a todos os grupos morais permanecem compartilhadas por todos, como, por exemplo, não matar, não roubar, não mentir e socorrer a quem estiver em perigo ${ }^{42}$. 
A Teoria da Moralidade Comum tem a experiência moral cotidiana como ponto de partida. Ela se baseia na moralidade comum, a qual não constitui um instituto inventado, mas algo que todos nós aprendemos no dia-a-dia. Por isso que as pessoas em geral sabem instintivamente o que é moralidade comum, e até mesmo aplicam a Teoria da Moralidade Comum no dia-a-dia, mesmo sem jamais terem estudado ou ouvido falar nela ${ }^{7}$.

Para que pertençam à instituição "moralidade comum", as normas morais devem ser aplicáveis a qualquer pessoa (desde que comprometida com a moralidade), independentemente de tempo ou lugar ${ }^{45}$. Com sua capacidade de permear todas as culturas, elas representam um verdadeiro "ponto de encontro" moral universal ${ }^{19}$.

A moralidade comum se baseia na natureza humana e deve ser a mesma para todas as pessoas. Contudo, isso não significa que deva existir um único padrão de moralidade mundial, nem que esta teoria resolverá todas as questões morais, nem mesmo que poderá ser racionalmente endossada por todas as pessoas ${ }^{48}$. Segundo esta linha de interpretação, incorporada por B\&C à obra discutida nesta tese, a moralidade comum não significa uma forma de moralidade particular, já que estas contêm normas não universais por questões culturais, religiosas e/ou institucionais ${ }^{7,45}$.

Imparcialidade e universalidade são características essenciais da moralidade comum. Segundo os autores aqui estudados, normas morais comuns jamais serão questionadas por pessoas moralmente comprometidas, pois elas são inerentes às suas realidades ${ }^{18}$.

Segundo eles, a moralidade comum compreende um sistema moral único compartilhado por todos os adultos racionais, capaz de lidar com todas as questões morais. "Lidar" também não significa solucionar, pois, em muitos casos, apenas distingue as soluções moralmente aceitáveis das inaceitáveis, separando o ético do não-ético e indicando apenas a solução mais moralmente adequada $^{43,48}$. 
A visão de que haveria apenas uma solução ideal para as questões morais até foi sustentada anteriormente por filósofos como Aristóteles (na Ética das Virtudes), Kant (na Deontologia) e Bentham (no Utilitarismo). Por outro lado, para Gordon, Rauprich e Vollmann, tanto B\&C (no Principialismo), como Gert e Clouser (na Teoria da Moralidade Comum), acreditam existir várias respostas fundamentadamente adequadas para um mesmo conflito moral ${ }^{48}$.

Para estes que acreditam em diversas soluções morais, resolver um conflito moral não significa buscar a única solução correta, mas apenas prover uma solução moral bem justificada. No caso, a moralidade comum não conduz a verdades absolutas. Justificar um ato pelo fato de ele ser o adotado por um grupo que compartilha a mesma moralidade não significa que ele seja a única verdade, mas apenas o ponto de vista de determinado grupo moral ${ }^{19}$.

É correto afirmar que existe uma dificuldade de se estabelecer paradigmas éticos universais - com exceção para o tema dos Direitos Humanos. Isso reflete a necessidade de reestruturação do discurso bioético, incluindo categorias mais dinâmicas e fáticas, como comunicação, linguagem, argumentação, diálogo, coerência, consenso e racionalidade ${ }^{20}$.

A língua é o idioma oficial de uma nação; o dialeto, uma variação social ou regional; e idioleto, uma variação individual de um dialeto. $\mathrm{O}$ idioma bioético é o conjunto linguístico da nação bioética, constituída por uma rede continental de pesquisadores. Ela possui um papel regulador, acima e a parte de dialetos específicos $^{54}$. Os dialetos correspondem às diversas teorias da bioética, como ocorre com o Principialismo. São eles que fazem a conexão entre a linguagem e a prática. Esta linguagem comum permite que um bioeticista neozelandes troque ideias com um bioeticista chinês ou norte americano, a despeito de seus dialetos particulares ${ }^{54}$. Os idioletos, por sua vez, não importando se são individuais ou compartilhados por um pequeno grupo, são a adaptação crítica muito específica, localizada, dos dialetos a contextos socioculturais diferentes dos que os originaram. Por exemplo, o Japão é um país periférico no que tange à produção de estudos bioéticos, se comparado ao Brasil ou ao Canadá ${ }^{54}$. 
Por outro lado, estes países centrais em relação ao Japão serão sempre periféricos se comparados aos Estados Unidos, até mesmo porque este será sempre um país central, já que a bioética, historicamente, foi um movimento estadunidense $^{54}$. Estas nações possuem diferentes moralidades, e elas não são universais, mas relativas a cada lugar, contexto biológico e sócio-políticocultural. Por óbvio, a prática Bioética também muda bastante de cultura para cultura, assim como de tempos em tempos ${ }^{19,20,21}$. Isso ocorre porque a Bioética não é estática, é metaeticamente relativa e porque existe um pluralismo histórico de cada nação. O relativismo metaético sustenta que diferentes observadores podem justificadamente atingir conclusões morais diferentes sobre um mesmo dilema ético, já que se baseiam em fundamentações morais diferentes, como crenças, valores e compromissos próprios dos grupos morais $^{19,20,21}$.

Já o universalismo, também metaeticamente falando, sustenta que haveria uma moralidade comum, compartilhada por todas as pessoas racionais $^{19}$. Este universalismo não se confunde com a moralidade comum em si, apesar de poder ser uma das características desta ${ }^{45}$. Por tais motivos, a análise dos conflitos morais em diferentes culturas necessita ser contextualizada. Impor a visão moral de uma cultura, ou nação, politicamente mais forte a outra menor, não consiste em um processo de contextualização, mas mera importação acrítica de conhecimento, o que se chama de imperialismo moral ${ }^{20}$.

Além da questão do universalismo, de acordo com Karlsen e Solbakk, deve-se ter em mente que não existe apenas uma teoria absoluta sobre a moralidade comum, mas sim várias. Segundo eles, isso, por si só, já compromete sua pretensão de uma teoria moral universal ${ }^{45}$. Além disso, nenhuma das teorias propostas sobre moralidade comum consegue ser completa e universal isoladamente. De acordo com esses dois autores, elas se baseiam na existência de diferentes níveis de moralidade comum, suas interrelações e co-extensões, o que, por si só, já gera outro problema, pois não se pode falar na existência de moralidade comum em todos os níveis lógicos, mas apenas nos mais elevados, fundamentais ${ }^{45}$. 
Outro ponto nebuloso consiste na natureza da Teoria da Moralidade Comum: se seria normativa, não-normativa ou mesmo ambas. Se considerada de natureza normativa, exige um conjunto de regras a serem universalmente obedecidas. Se não-normativa, deverá ser empiricamente identificável em qualquer grupo cultural. $\mathrm{Na}$ opinião de B\&C, tanto histórica quanto antropologicamente, melhor seria defender que ela possui as duas naturezas conjuntamente ${ }^{18}$.

Outro questionamento reside no fato de se a moralidade comum, tal qual ocorre com as moralidades particulares, poderia sofrer variações de acordo com o grupo moral em que se insere. Beauchamp defende que essas mudanças podem (e até devem) acontecer, mas desde que de forma pontual e enquanto uma exceção, sem comprometer seu núcleo básico fundamental ${ }^{42}$. Para o autor deve-se ter em mente que o excesso de instabilidade nas diretrizes morais impediria a justificação de uma Teoria da Moralidade Comum; por outro lado, o excesso de estabilidade impediria a aplicação de uma mesma teoria ao longo do tempo, ou em culturas muito diferentes ${ }^{42}$. Neste sentido, o autor afirma que o ideal é que, em uma teoria, haja instabilidade em uma ou outra norma, mas que seus objetivos gerais sempre permaneçam estáveis ${ }^{42}$.

Já para Gordon, Rauprich e Vollmann, justamente por ser a moralidade comum dotada de universalidade e de instabilidade apenas suficiente para torná-la dinâmica, é que ela deveria ser vista como um superprincípio, um verdadeiro princípio-guia, fundamentalmente acima dos demais, guiando-os ${ }^{48}$.

Porém, para o próprio Beauchamp, o referencial da moralidade comum parece ir além, funcionando, na solução dos conflitos morais, não apenas como um superprincípio organizador, mas como uma coleção de princípios e regras (tal qual ocorre com o próprio Principialismo) ${ }^{49}$.

Até mesmo por ser composta por princípios e regras (estas oriundas de princípios) é que as contraposições epistemológicas assimétricas acabam se tornando inevitáveis na Teoria da Moralidade Comum ${ }^{43}$. Nestas 
contraposições, as normas mais elevadas e genéricas (e não há norma mais genérica e elevada do que os princípios na forma de superprincípios) prevalecem em detrimento das mais rasas e específicas (como as regras) ${ }^{48}$. Para Gordon, Rauprich e Vollmann, esta forma de aplicação concreta da Teoria da Moralidade Comum consiste em uma exigência de se revisar as normas mais específicas (regras) à luz das mais genéricas (princípios). Desta maneira, as regras passam a ser obrigatoriamente revisadas à luz dos princípios e os princípios à luz dos superprincípios. Isso confere maior consistência e confiabilidade teleológica às aplicações concretas ${ }^{48}$.

\subsubsection{As críticas de Clouser e Gert ao uso da Teoria da Moralidade Comum como teoria de fundamentação do Principialismo}

As teorias morais, quando bem estruturadas, constituem unidades capazes de refletir a universalidade da moral. Elas são capazes de autoeliminar quaisquer de seus descompassos. Uma teoria moral adequada não pode ser apenas um conjunto mais ou menos sistematicamente relacionado de princípios e regras ${ }^{6}$.

B\&C defendem que as teorias morais estão no topo da hierarquia de justificação, seguidos pelos princípios e, por fim, pelas regras. Clouser e Gert criticam esta afirmação, pois, segundo eles, trata-se de uma maneira inadequada, minimalista e conveniente de se explicar o que é uma teoria moral $^{6}$. Segundo estes autores, o ideal para B\&C é que uma teoria moral se resuma ao que o seu Principialismo consegue oferecer: um conjunto de princípios e regras mais ou menos sistematicamente relacionados ${ }^{6}$.

Clouser e Gert destacam, contudo, que no Principialismo, embora as teorias estejam no topo de sua hierarquia de justificação, elas não assumem nenhum papel no raciocínio moral prático; em seus lugares, os princípios é que assumem de fato o papel de tribunal de última instância ${ }^{6}$. Segundo estes críticos, não há nada de errado em se utilizar princípios nas análises dos casos concretos em geral. Contudo, usá-los como simples substitutos de suas teorias 
éticas de origem parece mais um esforço inconsciente de se agarrar a elas próprias $^{6}$.

Mas, de onde vieram os princípios do Principialismo? Por que foram eles os escolhidos e não outros? O que fazer quando eles estejam em conflito? Como e quando dar prioridade? São perguntas, segundo Clouser, sem respostas, pois os princípios do Principialismo não passariam de um grande resumo histórico das teorias da "Justiça" de John Rawls, do "Utilitarismo" de Stuart Mill, da "Autonomia" de Immanuel Kant e da "Não-maleficência" de Bernard Gert ${ }^{7}$.

Para Clouser e Gert, não se nega que tais teorias sejam essenciais à moralidade, apenas precisariam ser minimamente relacionadas, de maneira a formarem um todo coerente dentro do Principialismo ${ }^{6}$. Diferentemente dos princípios trabalhados pelos quatro autores acima isoladamente em suas teorias, quando dentro do Principialismo, eles não conseguem formar uma teoria moral única, delimitada e integrada ${ }^{7}$. É correto afirmar que é requisito de uma teoria moral propriamente dita conter considerações sobre as consequências de sua aplicação, inclusive com regras sobre situações de imparcialidade. Mas não basta apenas mencionar que deva respeitar tudo isso: deve mostrar também como todas essas considerações devem se integrar ${ }^{6}$.

No caso do Principialismo, no entanto, a maior crítica recebida não foi o fato de não possuir uma teoria própria de princípios. Segundo Clouser, ainda mais grave é o fato dele não possuir "qualquer" teoria, capaz de reunir seus princípios (porque são derivados de teorias diversas) de maneira adequada a funcionar como se uma teoria autônoma o fosse ${ }^{7}$.

Clouser e Gert vão mais longe, afirmando que o Principialismo carece de unidade sistemática criando, assim, dois problemas - um prático e outro teórico: como não há uma teoria moral que reúna seus princípios adequadamente, não existe um guia de ação unificado que gere regras claras, coerentes, abrangentes e específicas para as ações ${ }^{6}$. Segundo eles, no Principialismo a discussão dos princípios é eclética, e isso é algo inevitável, já que cada um 
deles é baseado em uma diferente teoria moral. Por exemplo, no princípio da autonomia, reconhece que Kant estava certo ao enfatizar a importância do indivíduo; já, no princípio da não-maleficência, reconhecem que Gert estava certo ao enfatizar a importância de que deve se evitar prejudicar os outros ${ }^{6}$.

Seguindo a mesma linha crítica dos autores aqui trabalhados, percebese que apenas com o uso de uma teoria moral unificada seria possível lidar com toda a amplitude de questões complexas que a Bioética cotidiana abarca. Somente assim, com um procedimento de decisão única, clara, coerente e abrangente, é que se chegaria a respostas verdadeira e moralmente válidas ${ }^{6}$.

Além disso, Garrafa questiona a falta de intervenção ética prática do Principialismo, em especial no que tange a solucionar problemas decorrentes da desigualdade econômica e social que se opera nos países periféricos. 0 autor defende o uso, em seu lugar, do que chamou de Bioética de Intervenção, não branda, utilitarista, organicamente solidária, política e concretamente ativa $^{63}$.

Outra vantagem de se possuir uma teoria moral válida, segundo Clouser e Gert, é que todos os indivíduos que lidem com um mesmo conflito moral poderiam se comunicar facilmente uns com os outros. Eles iriam concordar com as características relevantes do caso, apesar de nem sempre chegarem à mesma decisão - já que o consenso não é consequência necessária do dialogo ${ }^{6}$. Contudo, por tais motivos o Principialismo tem dificuldade de conciliar a teoria com a prática, já que seu maior problema não se encontra exatamente no conteúdo dos princípios, mas na sua forma de aplicação. Filosoficamente, portanto, o ponto de partida de diversas das críticas à obra de B\&C está na sistematização dos seus princípios ${ }^{6}$.

Nesse sentido, Clouser e Gert chegam a dizer que os princípios do Principialismo não trabalham como guias de ações, chegando a ser conflitantes intrinsecamente. Representam meros nomes para uma coleção de pontos superficiais, ou "check-lists", uma vez que enumeram algumas obrigações 
morais oriundas de teorias morais diferentes e desconexas. Assim, apenas reúnem resumos de valores morais a serem obedecidos ${ }^{6}$.

Parece ser, portanto, que como reação à crítica da falta de uma teoria para sustentação conveniente do Principialismo, a Teoria da Moralidade Comum passou a ser trabalhada na obra de B\&C. Este ingrediente passou a existir na $4^{a}$. edição do livro, porém, foi a partir da $5^{a}$. edição que foi dada maior visibilidade ao tema, que a partir daí passou a ser utilizada como teoria-base do Principialismo ${ }^{11,15,45}$. Na $7^{a}$. e mais recente edição, uma das mudanças que chama mais a atenção é justamente aquela que se refere à constante presença da Teoria da Moralidade Comum ao longo da mesma. Segundo os próprios $B \& C$, ela foi mais bem "explicada e fundamentada" nesta edição ${ }^{18}$, em uma clara tentativa de dar resposta às críticas.

Porém, apesar de B\&C terem encontrado uma "solução" para a falta de uma teoria de fundamentação do Principialismo, o fato é que cada um dos princípios continua, na visão de Clouser e Gert, como apenas um lembrete de que existe um valor moral a ser obedecido ${ }^{6,7}$. O problema surge exatamente quando o respeito a dois ou mais princípios possa levar a comandos diferentes, ou mesmo opostos, o que se costuma chamar de conflito ético. No Principialismo, os princípios não obedecem a qualquer disposição hierárquica, são válidos prima facie. Em caso de conflito, segundo Patrão-Neves, somente com a devida análise concreta, com todas as suas nuances, poder-se-á definir ou, ao menos, indicar o princípio que deve ter preferência em relação aos demais ${ }^{5}$.

Nestes casos, os princípios abstratos devem ser especificados em princípios materiais e confrontados uns com os outros, a fim de se estabelecer qual ou quais nortearão a análise do conflito moral ${ }^{6}$. Desta forma, segundo Clouser, os princípios escolhidos acabam não guardando semelhança com as suas teorias-mães, e a proposta termina por evocar até quatro princípios conflitantes em um mesmo caso, ou melhor, usando até quatro teorias morais conflitantes para uma mesma situação, o que faz com que esses princípios sejam resumidos a frases vazias ${ }^{7}$. 
É necessário registrar que os princípios devidamente contextualizados em suas próprias teorias são claros, contudo, seus objetivos dentro do Principialismo é que se tornam ambíguos. De acordo com a crítica histórica de Clouser e Gert, não se tratam de diferentes interpretações, naturais a todos os princípios, mas sim de como se comportam na aplicação a determinadas situações $^{6}$. Segundo eles, em uma teoria genuína, mesmo que a mesma possua mais de um princípio, a relação entre estes princípios é claramente preestabelecida ${ }^{6}$.

Para Clouser e Gert, a leitura dos capítulos sobre os princípios na obra de B\&C mostra ao leitor apenas como os princípios são interpretados pelos próprios autores, pois os quatro capítulos não esboçam qualquer comando de ação para a solução dos conflitos morais; apenas apresentam longas discussões, repletas de exemplos de como os próprios autores do Principialismo pensam sobre eles ${ }^{6}$. Assim, cada um dos princípios da proposta Principialista não passaria de um atalho para as suas próprias discussões sobre eles. Infelizmente, atalhos não são ferramentas metodológicas, uma vez que advém de teorias não conectadas e resumem, sem qualquer opção de aplicabilidade prática, suas teorias de origem ${ }^{6}$.

Daí decorre mais dois graves problemas do Principialismo, ainda segundo Clouser e Gert: o primeiro é que os princípios, da maneira como estão apresentados no Principialismo, são supostamente estruturas bem delineadas e justificadas; as pessoas se sentem seguras aplicando-os (ou acreditando que os aplicam $)^{6}$. O segundo é que, ao aplicá-los, as pessoas não estão conscientes de todos os estágios de suas decisões morais, visto que estes princípios não são diretrizes claras e imperativas, mas apenas uma coleção de sugestões e observações dos autores originariamente proponentes - muitas delas até ocasionalmente conflitantes ${ }^{6}$.

Clouser e Gert terminam suas análises de modo ainda mais fortemente crítico ao afirmar que embora o Principialismo funcione como uma ferramenta moral que possibilita a organização e discussão do aparentemente caótico 
mundo dos valores na prática biomédica e clínica - mostrando certa facilidade instrumental - traz o risco de que seja repetido como um "mantra", ou seja, de que acabe sendo aplicado de forma acrítica, descontextual e generalizada ${ }^{6}$.

Contudo, muitas destas críticas são aplicáveis a quase todas as teorias, já que nenhuma delas, especialmente quando se trata de soluções para os conflitos morais, conseguiu até hoje ser completa e livre de críticas. Assim é que o Principialismo, até mesmo por não constituir uma teoria propriamente dita, parece também ter falhado, tal qual suas teorias de origem, nesta tarefa.

\subsection{O Princípio da Justiça em B\&C}

Definir o que é o Princípio da Justiça, ou mesmo o que a justiça representa, não é tarefa fácil. Sua definição e aplicação, dentre os quatro princípios que compõem o Principialismo, talvez sejam as mais complexas e detalhadas.

Geralmente, ela é apresentada no contexto da bioética segundo critérios de equidade e de justa distribuição - conforme a teoria de Rawls. A especificação do Princípio da Justiça tampouco é menos rebuscada, porque, além de princípio ético, pode representar um valor, uma virtude ou uma instituição $^{32}$. A justiça como um valor de coesão social costuma ser usada quando se apontam causas e problemas de (in)justiça social. Refere-se a uma virtude, quando usada como na descrição aristotélica de pessoa justa. Por fim, pode representar uma instituição, quando se tratar do Poder Judiciário dos países em geral ${ }^{32}$.

Seja um princípio, um valor, uma virtude ou uma instituição, a justiça pode ainda se exteriorizar sob três formas: distributiva (quando tratar da repartição de encargos e de vantagens sociais); comutativa (quando zelar pela correção das trocas sociais); e retributiva (quando tratar de uma reparação de danos) $)^{7}$. 
Clouser e Gert afirmam que o Princípio da Justiça é o que mais falha como uma diretriz, pois seria impossível de ser seguido. Baseado numa visão de justiça distributiva, igualitária, ele prima facie obriga as pessoas a tratarem seus semelhantes de forma igual. Isso faz surgir novos questionamentos, tampouco respondidos, como "qual a maneira de se tratar bilhões de pessoas (tão diferentes) de forma igual?", ou mesmo "igual em relação a quê: habilidade, interesse, necessidade ou mérito?" ${ }^{\prime 6}$.

A "justiça como equidade" rawlsiana é de fundo contratualista, substituindo um "estado de natureza" por uma "posição original" na justa distribuição de bens primários. Nela, saúde, alimentos e direitos em geral, por exemplo, são tidos como "bens" a serem "dados" segundo critérios de justa distribuição. O princípio da diferença, por sua vez, permite desigualdades na medida em que possam igualar a situação de grupos menos privilegiados à de mais beneficiados ${ }^{22}$.

Justamente, por ter tantas vertentes, foi que Habermas e Rawls travaram debates históricos sobre o que seria "justiça". Habermas, sociólogo e filósofo alemão, com uma visão de justiça mais ampla, envolvendo temas como religião e moral, trabalha um modelo de democracia deliberativa procedimental, em que a busca do consenso ocorre por meio do reconhecimento das diferenças ${ }^{64}$.

Rawls, filósofo estadounidense, por sua vez, adota uma concepção de justiça quase que unicamente voltada ao âmbito político e com o objetivo de se alcançar o consenso entre sujeitos racionais por meio de um conteúdo de princípios básicos de justiça dentro de uma sociedade plural, se utilizando de um "véu da ignorância", segundo o próprio, fundamental para a caracterização das partes como moralmente livres, iguais e providas de desinteresse mútuo ${ }^{22}$. Este autor parte do pressuposto de que vivemos em sociedades complexas, onde não se deveria apelar a um conjunto de valores compartilhados (a exemplo da moralidade comum) como forma de solução dos conflitos. Assim, um dos maiores problemas do(s) princípio(s) da justiça é justamente encontrar princípio(s) de validade geral que possibilitem a distribuição de direitos e de 
deveres de forma a ser(em) racionalmente aceita(os) por indivíduos morais e racionais $^{22}$.

Apesar de tantas dificuldades conceituais, o Princípio da Justiça é um dos mais relevantes à Bioética, em especial, à latino-americana. Dos quatro princípios trabalhados pelo Principialismo, este é o mais afeto às questões voltadas ao público e ao coletivo, temas de interesse dos países periféricos do Hemisfério Sul.

Apesar disso, a discussão do Princípio da Justiça contida na obra de B\&C parece centrar demasiadamente no ponto de vista dos autores, sem as devidas explicações e merecendo, portanto, um aprofundamento ao tema, objeto do presente estudo. Clouser destaca que perguntas básicas como: "o que é justiça?", "qual de suas vertentes deve ser aplicada?", "como agir com equidade?" ou "qual seria a devida alocação de recursos?", não são respondidas com a leitura da obra ${ }^{7}$.

\subsubsection{Críticas ao Princípio da Justiça no Principialismo}

Apesar de sua importância no mundo dos princípios, o da justiça, tal qual ocorre com os temas de interesse coletivo, segundo Garrafa ${ }^{12}$ foi sempre deixado em segundo plano no Principialismo. Segundo Clouser, sua discussão no livro "Principles of Biomedical Ethics", assim como a dos demais princípios que não o da justiça, sempre foi superficial ${ }^{7}$.

De certo modo o que está dito acima é confirmado por De Grazia e pelo próprio Beauchamp, que defendem que o Princípio da Justiça talvez seja o mais subjetivo de todos, carecendo de conteúdo normativo. Ao ser invocado em um conflito moral, acaba sendo aplicado da maneira como seu interlocutor imagina que seja um ideal de justiça ${ }^{44}$. 
Clouser e Gert desde 1990 já afirmavam que o Princípio da Justiça é o que mais falha como uma diretriz, pois seria impossível de ser seguido, já que, baseado numa visão de justiça distributiva, igualitária, ele prima facie obriga as pessoas a tratarem seus semelhantes de forma igual. Por esta razão, conforme aqui já assentado, questões essenciais surgem e não são respondidas, como: "qual seria a maneira de se tratar bilhões de pessoas (tão diferentes) de forma igual", ou mesmo "igual em relação a quê - habilidade, interesse, necessidade, mérito"? .

Rawls, ao trabalhar o Princípio da Justiça, tampouco foi capaz de se livrar das críticas. Habermas, que foi um dos maiores comentadores da teoria rawlsiana, discute o fato de o autor ter apresentado sua teoria como uma de fundo político liberalista, mais compatível com o pluralismo das sociedades e mais fácil de ser aceita - o que não aconteceria se reivindicasse os direitos das minorias. Rawls, no entanto, defende que, em sua teoria, todos os homens seriam a princípio iguais - o que, na prática, traz incertezas à sua aplicação concreta $^{64}$.

No outro oposto, o princípio da beneficência é o que mais aparenta ser um guia de ações. Clouser e Gert defendem que o Princípio da Justiça até mesmo poderia ser ocasionalmente substituído pelo princípio da beneficência. Contudo, estes autores também não apresentam uma fórmula de se determinar

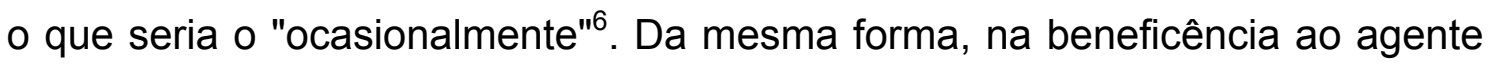
é dito o que fazer: "ajudar as pessoas". Aqui, o problema já se inicia no conceito de "ajudar" - que nunca pode ser descontextualizado ${ }^{7}$.

Porém, o princípio que mais se contrapôs ao da justiça, nessa questão das críticas à obra de B\&C, foi o da autonomia. Enquanto este era excessivamente utilizado na prática pelos seguidores do Principialismo, em lado diametralmente oposto se encontrava o Princípio da Justiça, quase que esquecido: "o eu empurrou o nós para uma posição secundária; o individual praticamente sufocou o coletivo" (p. 129) ${ }^{12}$. 
A Bioética trabalhada pelo Instituto Kennedy de Ética sofreu uma forte redução da sua concepção potteriana original. O tema da autonomia voltado especialmente a questões biomédicas foi maximizado, tornando-se um verdadeiro superprincípio. Em alguns países, a visão individual dos conflitos passou a ser aceita como a única vertente de solução dos conflitos éticos $^{12}$. Inclusive, em diversas nações indígenas, como os ianomâmis ou terenas, ou mesmo na cultura oriental em geral, o tema da autonomia é pouco conhecido. Assim, esta maximização da autonomia, a depender do contexto, tanto pode ser sadia, levando ao respeito à individualidade, quanto pode ser egoística, levando ao individualismo mais extremo e até mesmo ao egoísmo, capaz de anular qualquer visão coletiva $^{12,65}$.

A super dimensão da autonomia na Bioética estadunidense, fez emergir uma visão singular e individualista dos conflitos, contudo, nenhum princípio é capaz de esclarecer sozinho os conflitos éticos ${ }^{12}$. O agir moral é uma constante escolha entre princípios de vias diversas, até opostas. Não se trata de uma questão de obedecer ou não a um princípio, a Bioética não pode se resumir a um único conjunto de princípios predeterminados ${ }^{52}$.

Além disso, o Principialismo é sabidamente insuficiente, em especial, da maneira como se apresenta, para a análise contextualizada de conflitos que exijam flexibilidade para uma determinada adequação cultural e para a abordagem de macro problemas bioéticos persistentes e/ou cotidianos enfrentados por grande parte das populações de países com altos índices de exclusão social - como a maioria das nações da America Latina e da África ${ }^{20}$.

Agravando esta insuficiência, deve-se ter em mente que a compreensão do que se denomina Bioética, neste início de século XXI, varia de um contexto a outro, de uma nação a outra, e, inclusive, entre estudiosos de um mesmo país; o processo de globalização econômica, longe de reduzir, aprofundou ainda mais as desigualdades verificadas entre as nações ricas e pobres, exigindo novas leituras e propostas ${ }^{20}$. 
Esta restrição de aplicabilidade do Principialismo se agrava ainda mais pela histórica exacerbação do princípio do respeito à autonomia ${ }^{5}$. Ele não só é dominante no Principialismo, como também domina a deontologia médica desde a época de Hipócrates ${ }^{52}$. Essa crítica à supervalorização da autonomia, todavia, segundo os próprios B\&C (2013), é infundada, pois há inúmeros casos onde os outros princípios podem preponderar sobre a autonomia. Alegam também os autores que em nenhum momento dizem que a autonomia deve prevalecer $^{18}$.

B\&C rebatem tais críticas citando apenas uma das características dos princípios: o fato de serem prima facie ${ }^{18}$. Contudo, seus maiores críticos, Clouser e Gert, em momento algum dizem que a autonomia prevalece por sua força de aplicação, mas sim pelo destaque que recebe nas subsequentes edições $^{6}$. Mas, a crítica mais concreta neste sentido é aquela que relata a maximização da autonomia com relação aos demais princípios na prática concreta de aplicação do principialismo aos diferentes conflitos morais que são estudados na tentativa de solução para os mesmos, principalmente frente a situações de pobreza e exclusão social ${ }^{12}$.

Ao se proceder à leitura de todo o conjunto da $7^{a}$. edição, percebe-se já de início que, fundamentalmente, pouco mudou, já que a autonomia é uma constância, estando presente no conteúdo dos demais capítulos. Exemplos são as seções: "Protegendo Pacientes Incapazes" (Protecting Incompetent Patients), presente no capítulo do princípio da não-maleficência; "Substituição na Tomada de Decisão para Pacientes Incompetentes" (Surrogate Decision Making for Incompetente Patients), presente no capítulo do princípio da beneficência; "Vulnerabilidade, Exploração e Discriminação na Pesquisa" (Vulnerability, Exploitation and Discrimination in Research), presente no capítulo da justiça ${ }^{18}$. 


\subsection{A Bioética de Intervenção}

A história da Bioética de Intervenção, assim como a do Principialismo, se confunde com a da própria Bioética. Todas as três se apresentam como verdadeiras satisfações a anseios sociais, a maioria consubstanciada na busca de soluções aos novos conflitos morais que foram surgindo ao longo dos últimos anos. Por exemplo, enquanto que, em tempos passados, os descobrimentos farmacêuticos podiam ser difundidos com a finalidade maior de promover a saúde, hoje, com uma das maiores participações no mercado mundial, a indústria farmacêutica representa um dos focos de discussão bioética sobre a comercialização da saúde ${ }^{24}$.

Assim, as novas descobertas são destinadas a quem "pode" comprar e não mais a quem "precisa". Tal qual a distribuição dos recursos financeiros costuma se dar de forma desigual entre os diferentes países, assim como entre seus próprios habitantes, o acesso à saúde também se apresenta hoje díspar, porém, diretamente proporcional à capacidade econômica de cada um ${ }^{24}$.

A década de 1960 significou uma época não só de avanços no campo sanitário, mas também de questionamentos e de buscas de novas soluções para os conflitos éticos. Assim foi que, dez anos depois, surgiu o modelo principialista de B\&C - o qual prevaleceu pelos anos seguintes, e talvez até os dias atuais a depender do ponto de vista ${ }^{23}$.

Com o passar do tempo, novos questionamentos envolvendo temas como vulnerabilidade e a própria comercialização da saúde, passaram a exigir um olhar bioético para além dos quatro princípios de B\&C. No Brasil, a realização do Sexto Congresso Mundial de Bioética (2002) e o surgimento da proposta da Bioética de Intervenção foram marcos referenciais de respostas a estas reações ${ }^{23}$.

Foi nesse contexto, portanto, que surgiu a Bioética Dura, ou Bioética de Intervenção, priorizando políticas públicas e tomadas de decisão que, de maneira utilitarista, privilegiam o maior número de pessoas e durante o maior 
espaço de tempo, buscando sempre as melhores consequências coletivas ainda que coexistindo com prejuízos proporcionalmente menores ${ }^{24}$.

Uma vez que é de natureza utilitarista, para o cálculo de busca das melhores consequências, a Bioética de Intervenção considera todas as pessoas contando cada uma por um, independentemente de qualquer de suas eventuais características particulares, para que a ação escolhida seja considerada verdadeiramente ética. Já a sua universalização deve ser de distribuição de bens, e não de valores morais - eis que estes necessariamente precisam ser contextualizados, ou seja, individualizados ${ }^{23}$.

Trata-se de uma nova forma de discussão política, e não de mais uma espécie de Biopolítica. Ela é responsável por assegurar de maneira prática e palpável as garantias universais e indivisíveis relativas a direitos de primeira (individuais), de segunda (sociais e econômicos) e de terceira (difusos) gerações, para todos os grupos humanos, mas, particularmente, para os segmentos historicamente vulneráveis e menos privilegiados ${ }^{24}$.

Ela prevê uma necessária intervenção ética prática, não se mantendo branda, mas política e concretamente ativa, assegurando uma metodologia utilitarista e consequencialistamente solidária, comprometida com a transformação social, de forma a assegurar a equidade aos diferentes sujeitos $^{63}$. Sua inclusão no contexto da presente tese, como referência de uma bioética criada genuinamenhte a partir de uma visão cultural diferenciada e construída no hemisfério sul do mundo que tem como base o referencial dos direitos humanos universais, foi definida com o objetivo de possibilitar a comparação - na discussão do trabalho - entre a ótica de B\&C para o campo da justiça em bioética e as propostas advindas da visão latino-americana, bastante diferentes como se verá mais adiante. 


\section{OBJETIVOS}

\subsection{Objetivo Geral}

Analisar as mudanças ocorridas na obra Principles of Biomedical Ethics de B\&C a partir das críticas com relação à sua pretensa universalidade surgidas no início dos anos 1990, por meio do estudo comparativo do processo de desenvolvimento da obra nas suas sete edições.

\subsection{Objetivos Específicos}

4.2.1. Apresentar criticamente a inclusão da Teoria da Moralidade Comum como fundamento teórico de sustentação do Principialismo a partir da $4^{a}$. edição da obra, comparando com o conteúdo existente nas edições subsequentes $\left(5^{\mathrm{a}}\right.$., $6^{\mathrm{a}}$. e $7^{\mathrm{a}}$.).

4.2.2. Apresentar criticamente as mudanças que ocorreram nas sete diferentes edições da obra de B\&C com relação ao Princípio da Justiça.

4.2.3. Compreender como a Bioética de Intervenção pode auxiliar no processo de contextualização dos institutos do Principialismo acima citados à realidade latino-americana. 


\section{MÉTODO}

Trata-se de pesquisa qualitativa, realizada por meio da análise de conteúdo de literatura pré-selecionada ${ }^{66}$. A amostra documental escolhida consistiu nas sete edições em inglês da obra "Principles of Biomedical Ethics", de B\&C.

Em uma pré-análise de conteúdo da fundamentação do Principialismo, por meio de uma leitura flutuante, observou-se a ausência da Teoria da Moralidade Comum nas três primeiras edições, sua inclusão na $4^{a}$. edição, e, finalmente, nas três últimas edições, sua presença, embora sendo trabalhada de maneiras diversas. Assim, buscou-se a presença da unidade de registro e da unidade de contexto "Teoria da Moralidade Comum" "como teoria de fundamentação do Principialismo" (respectivamente) apenas da $4^{\text {a }}$. edição (inclusive) até a atual $7^{\mathrm{a}}$.

No que tange aos princípios em espécie, que são quatro na obra, optouse pelo da Justiça, pois, segundo a literatura, é o mais afeto às questões relacionadas aos países periféricos, tendo sido deixado em uma espécie de segundo plano pelos autores $B \& C^{13,14}$. Quanto a este, procuraram-se as unidades de registro e de contexto "Princípio da Justiça" "no Principialismo" ao longo das sete edições ${ }^{66}$.

Diferentemente da Teoria da Moralidade Comum, o princípio citado esteve presente ao longo das sete edições, porém, sofrendo algumas mudanças, o que se percebeu por meio da leitura flutuante e o que levou à análise de todas elas neste ponto ${ }^{66}$. Outra peculiaridade do princípio foi a constante presença de certas categorias ao longo das edições: moralidade comum; Bioética; saúde como um bem; mínimo existencial; confidencialidade; privacidade; vulnerabilidade; exploração; discriminação; busca do bem-estar; equidade; seleção de pacientes; alocação de recursos; princípio da necessidade; pesquisa clínica; justa oportunidade; justiça distributiva; 
capacidade para pagar; prevenção; e teorias do princípio da justiça segundo $B \& C$.

Isso fez com que se optasse pela análise das mencionadas categorias em separado na sua maioria, pois algumas, pelo fato dos autores terem as trabalhado em conjunto na obra, acabaram sendo aqui também reunidas. Por fim, destacaram-se também as mudanças de algumas nomenclaturas realizadas por $\mathrm{B} \& \mathrm{C}$.

Os capítulos, itens e subitens selecionados foram:

1a. edição [...]

6. The Principle of Justice, 168

The Concept of Justice, 169

Material Principles of Justice, 172

Relevant Properties, 175

Fair Opportunity, 183

Macroallocation, 188

Microallocation, 192

$2^{a}$. edição [...]

6. The Principle of Justice, 183

The Concept of Justice, 184

Material Principles of Justice, 187

Relevant Properties, 191

Fair Opportunity, 197

Macroallocation and Health Policy, 201

Microallocation, 209

$3^{a}$. edição [...]

6. The Principle of Justice, 256

The Concept of Justice, 257

Principles of Justice, 259

Theories of Justice, 265

Fair Opportunity, 270

The Right to a Decent Minimum of Health Care, 275

Priorities in the Allocation of Health-Care Resources, 283

Rationing Health Care, 290

Conclusion, 301

$4^{a}$. edição 1. Morality and Moral Justification, 3

Morality and Ethical Theory, 4

[...]

2. Types of Ethical Theory, 44

[...]

Principle-Based, Common-Morality Theories, 100

6. Justice, 326

The Concept of Justice, 327

Theories of Justice, 334

Fair Opportunity, 341

The Right to a Decent Minimum of Health Care, 348 
The Allocation of Health Care Resources, 361

Rationing through Priorities in the Health Care Budget, 366

Rationing Scarce Treatments to Patients, 378

Conclusion, 386

[...]

8. Virtues and Ideals in Professional Life, 462

$[\ldots]$

Moral Ideals, 483

5a. edição PART I

1. Moral Norms, 1

Ethics and Morality, 1

[...]

PART II

[...]

6. Justice, 225

The Concept of Justice, 226

Theories of Justice, 230

Fair Opportunity, 235

The Right to a Decent Minimum of Health Care, 239

The Allocation of Health Care Resources, 250

Rationing and Setting Priorities, 253

Rationing Scarce Treatments to Patients, 264

Conclusion, 272

[...]

PART III

9. Method and Moral Justification, 384

[...]

Common-Morality Theory, 401

Conclusion, 408

6a. edição PART I MORAL FOUNDATIONS

1. Moral Norms, 1

[...]

The Common Morality as Universal Morality, 2

Particular Moralities as Nonuniversal, 05-09

[...]

PART II MORAL PRINCIPLES

[...]

7. Justice, 240

The Concept of Justice, 241

Theories of Justice, 244

Fair Opportunity and Unfair Discrimination, 248

Vulnerability and Exploitation, 253

National Health Policy and the Right to Health Care, 258

Global Health Policy and the Right to Health, 264

Allocating, Setting Priorities, and Rationing, 267

Conclusion, 280

PART III THEORY AND METHOD

[...]

10. Method and Moral Justification, 368

[...]

Common-Morality Theory, 387

Conclusion, 397

$7^{\text {a }}$. edição PART I MORAL FOUNDATIONS

1. Moral Norms, 1

[...]

The Common Morality as Universal Morality, 2

Particular Moralities as Nonuniversal, 05-09 


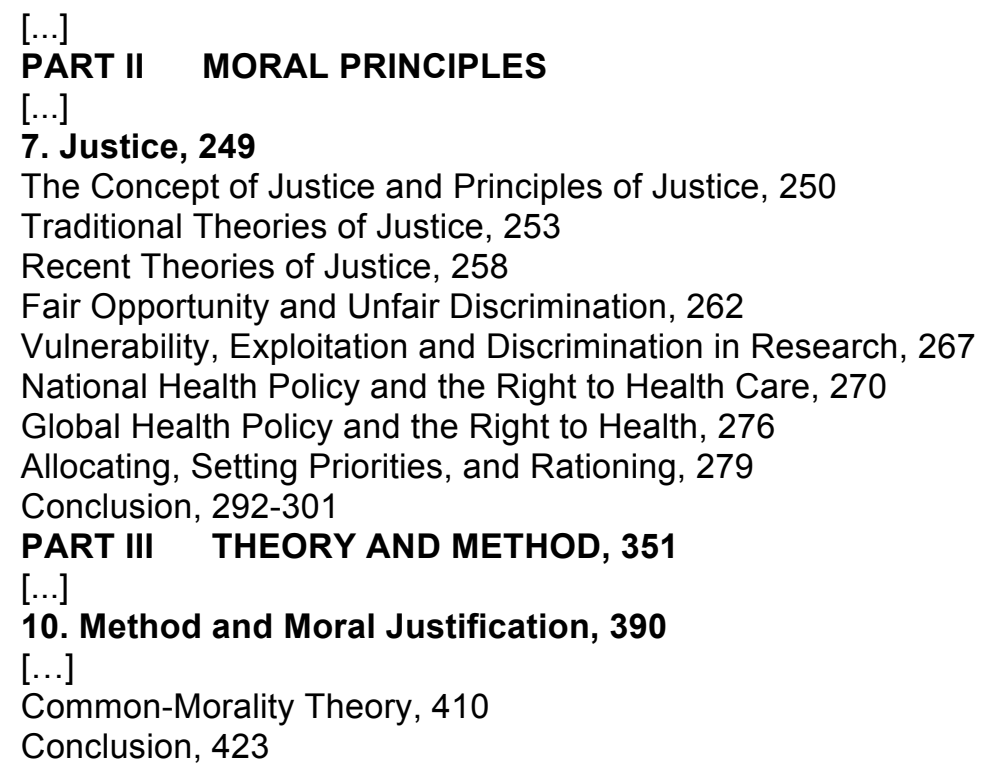

Optou-se por utilizar todas as edições em inglês, por uma questão de se extrair dados mais fiéis e por razões de paralelismo, tendo em vista que apenas a $4^{\mathrm{a}}$. edição foi traduzida para o português. Isso também permitiu a livre tradução, de acordo com a interpretação ampla que aqui pôde ser realizada.

A fase de exploração do material consistiu em um trabalho de fichamento dos capítulos, itens e subitens acima citados. Linha à linha, as partes pré-selecionadas foram transcritas e comparadas, sempre uma edição em contraposição à anterior (quando presente) e à posterior (quando presente), em tabelas do programa Word®.

Cada parágrafo foi transcrito em linhas diferentes dentro das tabelas, estas quais, por sua vez, com quatro colunas cada: duas com os conteúdos das duas edições que estavam sendo contrapostas e outras duas com as respectivas páginas dos parágrafos.

Neste trabalho de transcrição, os parágrafos foram posicionados de forma a se identificar com maior facilidade os pontos (não) correspondentes. Foram coloridas de vermelho as alterações pontuais e de azul as maiores que foram transpostas a outras partes do livro, estas, com suas pequenas alterações também coloridas de vermelho. 
Após os destaques supra mencionados, nova leitura foi realizada, buscando-se nos conteúdos as mudanças responderiam os objetivos do presente estudo. Daí, foram realizadas livres traduções (pela própria pesquisadora, que domina o idioma) apenas destas partes, assim como a análise do material propriamente dito. Nesta fase, usou-se como um referencial o livro "Análise de dados qualitativos" de Gibbs (2009) ${ }^{67}$.

A pesquisa foi toda de baixo custo, envolvendo apenas material de escritório e livros e foi totalmente financiada pela pesquisadora.

Devido à ausência de vinculações institucionais e/ou comerciais da pesquisadora com o objeto de pesquisa, não houve conflitos de interesse presentes. Tampouco, a pesquisa precisou ser submetida a Comitê de Ética em Pesquisa, já que não envolveu direta, nem indiretamente, seres humanos ou animais. 


\section{RESULTADOS E DISCUSSÃO}

\subsection{Com relação à Teoria da Moralidade Comum}

\subsubsection{Alterações ao longo das edições}

\section{Alterações da $5^{\mathrm{a}}$. frente à $4^{\mathrm{a}}$. edição}

$\mathrm{Na} 1^{\mathrm{a}}$., na $2^{\mathrm{a}}$. e na $3^{\mathrm{a}}$. edição da obra não existem referências à moralidade comum, ou à sua teoria ${ }^{17,31,68}$. A $4^{a}$. edição foi a primeira a tocar nos temas apenas nos dois capítulos iniciais do livro: "Morality and Moral Justification" (Moralidade e Justificação Moral) e "Types of Ethical Theory" (Tipos de Teorias Éticas) $^{16}$.

Nesta $4^{a}$. edição, definiram moralidade como convenções sociais sobre condutas humanas certas e erradas tão amplamente compartilhadas que formam um consenso comunitário estável (todavia, normalmente incompleto). Enquanto ética seria um termo geral que tanto se referiria à moralidade quanto à teoria ética ("The term morality refers to social conventions about right and wrong human conduct that are so widely shared that they form a stable (although usually incomplete) communal consensus, whereas ethics is a general term referring to both morality and ethical theory. (The terms ethical and moral are here constructed as identical in meaning)" - p. 5-6) ${ }^{16}$ - isso foi mantido na $5^{\mathrm{a}}$. edição, retirando apenas a parte que falou da ética (p. 3$)^{69}$.

Também definiram, na $4^{a}$. edição, moralidade comum, como uma compilação de normas de conduta humana socialmente aprovadas. Ela reconhece muitas (i)legítimas formas de conduta que podem ser apreendidas por meio do uso da linguagem dos "direitos humanos", assim como representa uma instituição social com um código de normas aprendíveis, existindo antes mesmo de sermos instruídos sobre suas regras relevantes e regulamentações ("In its broadest and most familiar sense, the common morality comprises 
socially approved norms of human conduct. For example, it recognizes many legitimate and illegitimate forms of conduct that we capture by using the language of "human rights". The common morality is a social institution with a code of learnable norms. Like languages and political constitutions, the common morality exists before we are instructed in its relevant rules and regulations. As we develop beyond infancy, we learn moral rules among with other social rules, such as laws" - p. 6) ${ }^{16}$. Na $5^{\mathrm{a}}$. edição, passaram a se referir à moralidade comum como um conjunto de normas compartilhadas por pessoas moralmente sérias ("We will refer to the set of norms that all morally serious persons share as the common morality" - p. 3$)^{69}$.

B\&C ainda acrescentaram, apenas na $4^{a}$. edição, que a moralidade comum não é completa ou isenta de falhas, mas que, mesmo assim, a usarão como ponto de partida para a teoria ética ("The common morality is not faultless or complete in its recommendations, but we will later argue that it forms the right starting point for ethical theory" - p. 6) ${ }^{16}$.

Sobre os códigos de ética, unicamente na $4^{\mathrm{a}}$. edição, explicavam que são escritos por grupos específicos como médicos, enfermeiras e psicólogos, sendo, algumas vezes, baseados em normas gerais como não causar danos aos outros (não-maleficência) e de respeito pela autonomia e privacidade mesmo quando não explicitamente declarados no preâmbulo ("Particular codes written for groups such as physicians, nurses, and psychologists are sometimes defended by appeal to general norms such as not harming others (nonmaleficence) and respecting autonomy and privacy, even if these were not explicitly considered in the drafting of the codes" - p. 6) ${ }^{16}$.

Falavam, também exclusivamente na $4^{a}$. edição, em "moralidade do senso comum" ("commonsense morality"), citando Sidwick, que assim chamava os princípios fundamentais da moralidade $\mathrm{e}$ as regras de veracidade $\mathrm{e}$ fidelidade, assim como outras afins, que seriam uma das fontes do conteúdo moral inicial de teorias éticas da moralidade comum ("As a rough generalization, what Henry Sidwick called the commonsense morality 
(morality's core principles and assorted rules of veracity, fidelity, and the like) is the source of the initial moral content for this type of theory" - p. 102) ${ }^{16}$.

Nesta $4^{\mathrm{a}}$. edição, afirmavam apenas que todas as teorias da moralidade comum são pluralistas, com dois ou mais princípios não-absolutos prima facie em seu nível normativo geral ("Common-morality theories, as we here stipulatively define them, are pluralistic. Two or more nonabsolute (prima facie) principles form the general level of normative statement' - p. 100) ${ }^{16}$.

$\mathrm{Na}$ versão imediatamente posterior, B\&C vão além, esclarecendo que mantiveram a existência de uma única moralidade comum universal, mas que, todavia, existem mais de uma forma de Teoria da Moralidade Comum, como a dos autores Ross e Frankena e, apesar das diferenças entre estas, são concordantes nos seguintes aspectos: todas as teorias da moralidade comum se baseiam inicialmente em crenças morais comuns divididas, não fazendo qualquer menção à razão pura, à racionalidade, à lei natural, ao senso moral especial, ou outras; todas as teorias da moralidade comum sustentam que qualquer teoria ética que não possa ser consistente com estes preteóricos julgamentos morais deveriam ser suspeitadas; e todas as teorias da moralidade comum são pluralistas, com dois ou mais princípios não-absolutos prima facie no nível normativo geral (p. 403) ${ }^{69}$.

$\mathrm{Na} 4^{\text {a }}$. edição, afirmavam exclusivamente que quaisquer novas normas vão apenas criativamente estender velhas normas ("Any 'new' norms will creatively extend old norms" - p. 102) ${ }^{16}$. Na $5^{\mathrm{a}}$., B\&C incluíram explicação de que não precisam de uma teoria para introduzir uma reforma moral, já que a inovação na ética quase sempre ocorre pela extensão e interpretação de normas que estão mais dentro do que além da moralidade comum (p. 404) ${ }^{69}$.

Tão somente na $4^{\mathrm{a}}$. edição explicavam também que dizer que os princípios têm suas origens na moralidade comum não é afirmar que suas formas finais serão idênticas às suas aparências na moralidade comum, já que, depois de serem formulados, os princípios ainda devem ser interpretados, especificados e balanceados para produzirem ética na Biomedicina ("To say 
that principles have their origins in the common morality is not to suggest that the final form in which they greet a reader of this book is identical to their appearance in the common morality [...] After the principles are so formulated, they will have to be further interpreted, specified, and balanced to produce an ethics for biomedicine" - p. 104) ${ }^{16}$.

Também somente na $4^{a}$. edição, citaram Clouser e Gert quando criticaram o Principialismo chamando-o de "mantra de princípios" ("mantra of principles"), por seus princípios serem repetidos como em um ritual de encantamento de normas, com pouca reflexão. Tais autores também se referem à "principialismo" como qualquer obra baseada em um corpo plural de potencialmente conflitantes princípios (prima facie), como o Principialismo e a teoria de Frankena. Em relação ao Principialismo, apontam os seguintes defeitos: seus princípios são pouco mais que nomes, check-lists ou chamadas para valores que deveriam ser lembrados, sem conteúdo moral substancial ou capacidade de guia de ação; não ter uma teoria unificada de justificação ou uma teoria geral que una os princípios de forma sistemática, coerente, formando um verdadeiro corpo de guias de ação, acarretando que estes guias de acão se tornam construções sem qualquer ordem sistemática; seus princípios prima facie frequentemente conflitam, mas a sua justificação é incapaz de determinar um procedimento de decisão ("Some commentators have criticized our account as a mere "mantra of principles", meaning that the principles often function like a ritual incantation of norms repeated with little reflection. H. Danner Clouser and Bernard Gert have so argued in an attack on "principlism", a term they use to designate all theories composed of a plural body of potentially conflicting prima facie principles - principally our account and Frankena's. They accuse us of the following defects in theory: (1) The "principles" are little more than names, check-lists, or headings for values worth remembering, leaving principles without deep moral substance or capacity to guide action. (2) Principle-analyses fail to provide a unified theory of justification or a general theory that ties the principles together as a systematic, coherent, and comprehensive body of guidelines, with the consequence that the alleged action-guides are ad hoc constructions lacking systematic order. (3) The prima facie principles (and other action guides in the framework) often conflict, and the 
underlying account is too indeterminate to provide a decision procedure to adjudicate those conflicts" - p. 106) ${ }^{16}$.

Nesta linha, na $4^{a}$. versão da obra, B\&C afirmavam que Clouser e Gert esperam grande unidade e sistemática conexão entre regras, um claro modelo de justificação e um procedimento prático de decisão, como consequencias de uma teoria, enquanto que a filósofa Annette Baier é cética em relação a cada uma destas condições, e até mesmo em relação à linguagem da teoria ("Clouser and Gert expect a strong measure of unity and systematic connection among rules, a clear pattern of justification, and a practical decision procedure that flows from a theory, whereas Annette Baier is skeptical of each of these conditions, and even of the language of 'theory" - p. 109) ${ }^{16}$. Na edição seguinte, reescreveram esta passagem, contudo, trocaram o nome da filósofa Annette Baier por "outros filósofos" ("other philosophers" - p. 407-8) 69.

B\&C explicavam, na $4^{a}$. edição apenas, que, quanto à crítica de que sua análise principiológica falha ao tentar prover uma teoria sistematizada, isso seria irrelevante, tendo em vista que nunca tentaram construir uma teoria ética geral e nem mesmo pretenderam que seus princípios imitassem, fossem análogos ou substitutos dos princípios fundamentais de teorias clássicas, como o utilitarismo e o kantismo ("Regarding the second criticism, that our principleanalysis fails to provide a systematic theory, we see the point but view it as irrelevant. We have not attempted a general ethical theory and do not claim that our principles mimic, are analogous to, or substitute for the foundational principles in leading classical theories such as utilitarianism (with its principle of utility) and Kantianism (with its categorical imperative)" - p. 106-7) ${ }^{16}$.

Sobre a crítica de que os princípios conflitam de tal maneira que o Principialismo não é capaz de solucionar, B\&C rebatiam, somente na $4^{\mathrm{a}}$. edição, dizendo que, a priori, todos os conflitos entre princípios são insolucionáveis. Assim, nenhum sistema de guias poderia razoavelmente antecipar um completo rol de conflitos morais, sendo o ponto de discussão no Principialismo a análise de dilemas onde os princípios (e outros compromissos) nos colocam em diferentes direções. Segundo os autores, representa uma 
virtude o Principialismo requerer especificação e um defeito, a teoria de Clouser e Gert, por meio de regras, escapar disso, pois é essencial deixar espaços, nas teorias, para interpretação, especificação e balanceamento ("Regarding the third criticism, that principles compete in ways our account cannot resolve, we acknowledge that conflicts among principles cannot be resolved a priori. No system of guidelines could reasonably anticipate the full range of conflicts, and the point of our discussion of dilemmas was to indicate circumstances in which principles (and other commitments) pull us in different directions [...] It is a virtue of our theory that requires specification, and a defect in Clouser and Gert's account that it purports through its rules to escape the need for specification [...] It is therefore essential to leave room for interpretation, specification, and balancing of principles and rules in the face of recurrent and recalcitrant conflicts" - p. 107) ${ }^{16}$.

$\mathrm{Na}$ conclusão da $4^{\mathrm{a}}$. edição, afirmaram que a Ética Biomédica contemporânea incorpora conflitos de complexidade considerável ("Contemporary biomedical incorporates ethics incorporates theoretical conflicts of considerable complexity, and the diverse theories explored in this chapter help us see why" - p. 111), além disso, que cada uma das teorias discutidas neste capítulo levou ao desenvolvimento e rejeição de proeminentes hipóteses em teoria moral ("Each of the theories discussed in this chapter has led to the development and rejection of prominent hypotheses in moral theory" - p. 111) ${ }^{16}$; o que quase não foi alterado na próxima edição ${ }^{69}$.

\section{Alterações da $5^{\mathrm{a}}$. frente à $4^{\mathrm{a}}$. e à $6^{\mathrm{a}}$. edição}

Na $5^{\mathrm{a}}$. edição, os capítulos iniciais do livro contidos na $4^{\mathrm{a}}$., "Morality and Moral Justification" (Moralidade e Justificação Moral) e "Types of Ethical Theory" (Tipos de Teorias Éticas), foram substituídos pelos "Moral Norms" (Normas Morais) e "Moral Character" (Caráter Moral), sem grandes alterações de conteúdo. Tais capítulos passaram a compor a Parte I do livro, agora dividido em três. A Parte II contém os capítulos sobre princípios e a Parte III incluiu capítulos que também tocam no tema da moralidade comum: "Moral 
Theories" (Teorias Morais) e "Method and Moral Justification" (Método e Justificação Moral), o último com um tópico exclusivo sobre a Teoria da Moralidade Comum ("Common-Morality Theory") ${ }^{69}$.

Sobre a definição de moralidade comum, na $4^{\text {a }}$. edição, B\&C a tinham como uma compilação de normas de conduta humana socialmente aprovadas $(\text { p. } 6)^{16}$. Na $5^{\text {a }}$., passaram a se referir à moralidade comum como um conjunto de normas compartilhadas por pessoas moralmente sérias ("We will refer to the set of norms that all morally serious persons share as the common morality" p. 3$)^{69}$. Na posterior, passaram a defini-la como um conjunto de normas compartilhadas por todas as pessoas comprometidas com a moralidade ( $p$. $3)^{70}$.

$\mathrm{Na} 5^{\mathrm{a}}$. edição, incluíram que a moralidade comum contém normas morais que conectam todas as pessoas em todos os lugares, nenhuma das outras normas consegue ser mais básica na vida moral. Até então, os direitos humanos representavam estas normas morais fundamentais no discurso público, mas a obrigação moral e a virtude moral não são partes menos vitais da moralidade comum ("The common morality contains moral norms that bind all persons in all places; no norms are more basic in the moral life [...] In recent years, the favored category to represent this universal core of morality in public discourse has been human rights, but moral obligation and moral virtue are no less vital parts of the common morality" - p. 3$)^{69}$. Na $6^{\mathrm{a}}$., passaram a afirmar apenas que a moralidade comum é aplicável a todas as pessoas em todos os lugares, sendo todas as condutas humanas certamente julgáveis por este modelo (p. 3$)^{70}$.

Apenas na $5^{a}$. edição, afirmaram que a moralidade vai além da moralidade comum, não podendo se confundi-las, eis que a moralidade comum compreende apenas as normas que todas as pessoas sérias aceitam como imperativas ("Morality consists of more than the common morality, and we should never confuse or conflate the two [...] The common morality, by contrast, comprises all and only those norms that all morally serious persons accept as authoritative" - p. 3$)^{69}$. 
Unicamente na $5^{a}$. edição, disseram que a moralidade, no sentido comunitário-específico, inclui as normas morais que surgem a partir de determinadas fontes particulares culturais, religiosas e institucionais. Por exemplo, diferentes padrões sociais de alocação de recursos para assistência de saúde e diferentes padrões religiosos e comunitários de doar a causas de caridade são partes da moralidade neste sentido ("By contrast, 'morality' in the community-specific sense includes the moral norms that spring from particular cultural, religious, and institutional sources. For example, different social standards of allocating resources for health care and different religious and communal standards of giving to charitable causes are parts of morality in this sense" - p. 3-4) $)^{69}$.

$\mathrm{Na} 5^{\mathrm{a}}$. edição exclusivamente, afirmavam que, algumas vezes, as pessoas acreditam falar com voz moral autoritária, estando sob a falsa crença de que estão sob o manto da moralidade comum (na verdade, a moralidade universal). Ao mesmo tempo, as normas da moralidade comum exigem interpretação se estão diante de uma prática ética viável. Tal interpretação é frequentemente alvo de árdua disputa para se resolver problemas particulares, tais como a forma de alocar órgãos ("Sometimes, persons who suppose that they speak with an authoritative moral voice operate under the false belief that they have the force of the common morality (that is, universal morality) behind them [...] At the same time, the common morality's norms do require interpretation if we are to have workable practical ethics. Such interpretation is often subject to vigorous dispute in order to resolve particular problems, such as how to allocate organs" - p. 4$)^{69}$

Mais uma explicação foi incluída na $5^{a}$. edição, a de que, se entendermos que a moralidade comum tem força normativa, ela deve ter força moral obrigatória a todos - este é o posicionamento adotado pelos autores do Principialismo ("If the appeals are normative, the claim is that the common morality actually has normative force: It establishes obligatory moral standards for everyone [...] The present authors do, indeed, understand the common morality in this way [...]" - p. 4$)^{69}$. Mantida na $6^{a}$. edição (p. 4$)^{70}$. 
Também inxertaram, na $5^{\mathrm{a}}$. edição, que, se entendermos que a moralidade comum tem força não-normativa, ela não terá força moral obrigatória. Posicionamento que, para os autores do Principialismo, é absurdo. ("nonnormative, or empirical, in which case they describe what all people believe. This thesis is more difficult to defend [...] It would be absurd to suppose that all persons do, in fact, accept the norms of the common morality" - p. 4) $)^{69}$ o que também foi mantido na edição seguinte (p. 4$)^{70}$.

$B \& C$, somente na $5^{\mathrm{a}}$. edição, colocavam que, mesmo em comunidades com costumes específicos, pode-se identificar a moralidade comum nos preceitos mais fundamentais ("We accept the thesis that morality in the community-specific sense [...] contains fundamental precepts. These fundamental precepts alone make it possible for persons to make crosstemporal and cross-cultural judgments and to assert firmly that not all practices in all cultural groups are morally acceptable" - p. 4-5) ${ }^{69}$.

Unicamente na $5^{a}$. edição, sobre a discussão da natureza das normas da moralidade comum, B\&C declararavam que não são absolutas, assim como que todas elas normas podem, de maneira justificada, serem sobrepostas ("Are the norms absolute? It is no objection to the norms in the common morality (or any other part of morality) that, in some circumstances, they can be justifiably overridden by other moral norms with which they conflict. All moral norms can be justifiably overridden in some circumstances" - p. 5$)^{69}$.

Tão somente nesta edição em comento, B\&C incluíram que, quando afirmam que se pautam na moralidade comum, significa que seu estudo não está baseado em filosofias específicas ou doutrinas teológicas ("When we say that the norms in this book are grounded in the common morality, we mean that they are not grounded in a particular philosophical or theological theory or doctrine" - p. 5$)^{69}$.

Também passaram a expor, na $5^{\mathrm{a}}$. edição, que, exatamente como a moralidade comum é aceita por todas as pessoas moralmente sérias, muitas 
profissões possuem, ao menos implicitamente, uma moralidade profissional com padrões de conduta que são normalmente aceitos pelos profissionais que são sérios sobre as suas responsabilidades morais ("Just as the common morality is accepted by all morally serious persons, so most professions contain, at least implicitly, a professional morality with standards of conduct that are generally acknowledged by those in the profession who are serious about their moral responsibilities" - p. 5$)^{69}$, passagem ainda constante da $6^{a}$. edição $(\text { p. 6) })^{70}$.

Expuseram, a partir da $5^{\mathrm{a}}$. edição, a ideia de sentido honorífico de profissão, mais bem refletida por "profissão aprendida" ("learned profession") o que pressupõe uma edução continuada em artes ou ciências ("The once honorific sense of profession is now better reflected in the term learned profession, which assumes an extensive education in the arts or sciences" - p. $6)^{69}$ - tal qual há na $6^{a}$. edição (p. 6$)^{70}$.

Somente na $5^{\mathrm{a}}$. edição, B\&C diziam que discorrerrão sobre duas "filosofias morais" ("moral philosophies") que, como o próprio Principialismo, foram baseadas na moralidade comum ("We begin by outlining two moral philosophies that, like our own, build from foundations in the common morality and appeal to principles as their structural basis" - p. 401-2). Estes autores são Frankena e Ross (p. 103-4) ${ }^{69}$.

Unicamente nesta $5^{\mathrm{a}}$. edição, B\&C diziam também que apresentarão sua própria versão da moralidade comum e de que não farão nenhuma tentativa de apresentar ou justificar uma teoria ética geral, apenas se preocupando com a vertente da moralidade comum assumida pelos autores nos capítulos anteriores voltada a questões de método e justificação em Ética Biomédica ("We turn now to the commitments of our own version of common-morality ethics. In doing so, we make no attempt to present or to justify a general ethical theory. Our concern is with the account of common morality assumed or developed in previous chapters and its connection to questions of method and justification in biomedical ethics" - p. 403) ${ }^{69}$. 
$\mathrm{Na} 4^{\text {a }}$. edição, apenas afirmavam que todas as teorias da moralidade comum são pluralistas, com dois ou mais princípios não-absolutos prima facie no nível normativo geral (p. 100) ${ }^{16}$. Somente na $5^{\mathrm{a}}$., B\&C foram além, esclarecendo que mantiveram a existência de uma única moralidade comum universal, mas que, todavia, existem mais de uma teoria da moralidade comum, como a dos autores Ross e Frankena. Apesar das diferenças entre estas teorias, concordam nos seguintes aspectos: todas as teorias da moralidade comum se baseiam inicialmente em crenças morais comuns compartilhadas, não fazendo qualquer menção à razão pura, à racionalidade, à lei natural, ao senso moral especial, ou outras; todas as teorias da moralidade comum sustentam que qualquer teoria ética que não possa ser consistente com estes preteóricos julgamentos morais deveria ser suspeitada; todas as teorias da moralidade comum são pluralistas, com dois ou mais princípios não-absolutos prima facie no nível normativo fundamental ("There is, we maintained in Chapter 1, a single, universal common morality. However, there is more than one theory of the common-morality, as the theories of Frankena and Ross indicate. Despite their differences, these theories share several features: First, all common-morality theories rely on ordinary, shared moral beliefs for their starting content; they make no appeal to pure reason, rationality, natural law, a special moral sense, or the like. Second, all common-morality theories hold that any ethical theory that cannot be made consistent with these pretheoretical moral judgments falls under suspicion. Third, all common-morality theories are pluralistic: Two or more nonabsolute (prima facie) principles form the general level of normative statement" - p. 403) ${ }^{69}$.

Já, na $5^{a}$. edição, B\&C incluíram o porquê de a moralidade comum servir melhor no papel de fundamentação na Bioética do que outras teorias éticas analisadas no livro ("We can now consider why the common morality is better suited to play a foundational role in bioethics than the ethical theories examined in Chapter 8" - p. 404) ${ }^{69}$, o que foi mantido na edição seguinte (p. 388 $)^{70}$.

Ainda na $4^{\text {a }}$. edição, afirmavam apenas que quaisquer novas normas vão apenas criativamente estender velhas normas (p. 102) ${ }^{16}$. Na subsequente, acresceram explicação de não precisam de uma teoria para introduzir uma 
reforma moral, já que a inovação na ética quase sempre ocorre pela extensão e interpretação de normas que estão mais dentro do que além da moralidade comum - quaisquer novas normas vão apenas criativamente estender velhas normas ("Nor do we need a theory in order to introduce moral reform. Innovation in ethics almost always occurs by extending and interpreting norms that are within rather than beyond the common morality [...] Any 'new' norms will creatively extend old norms" - p. 404 ${ }^{69}$. Tudo mantido na $6^{\text {a }}$. edição (p. 389 $)^{70}$.

Excepcionalmente na $5^{a}$. edição, diziam que muitos autores passam a impressão de que apenas uma teoria poderia solucionar conflitos morais, quando, porém, na verdade, nenhuma delas consegue de maneira direta e incontroversa passar da teoria à prática, mesmo dentre pessoas que adotam a mesma teoria ("Many moral philosophers convey the impression that if only we could find a correct theory we could resolve our problems by bringing that theory to bear on them [...] In truth, however, there is no direct, uncontroverted passage from theory to practice or resolution, even among persons who hold the same theory" - p. 404-5) ${ }^{69}$.

$\mathrm{Na} 5^{\mathrm{a}}$. edição, trouxeram afirmação de que se uma teoria ética rejeitasse qualquer dos quatro princípios defendidos neste livro, os autores teriam razões para duvidar da teoria, e não dos princípios ("If an ethical theory were to reject any of the four clusters of principles defended in this book, for example, we would have a sound reason for healthy skepticism about the theory, not for skepticism about the principle(s)" - p. 405) ${ }^{69}$. Isso foi mantido na $6^{a}$. edição (p. $388)^{70}$.

Unicamente na $5^{\mathrm{a}}$. edição, esclareciam que as teorias tentam capturar o ponto de vista moral, eis que a moralidade é a âncora da teoria, e não o contrário ("A moral theory attempts to capture the moral point of view. Morality is the anchor of theory; theory is not the anchor of morality" - p. 405) ${ }^{69}$.

Anteriormente, na 4a . edição, afirmavam que Clouser e Gert esperam, de uma teoria, grande unidade e sistemática conexão entre regras, um claro modelo de justificação e um procedimento prático de decisão, enquanto que a 
filósofa Annette Baier é cética em relação a cada uma destas condições - até quanto à própria linguagem da teoria $(p .109)^{16}$. Na seguinte, reescreveram isso, contudo, substituindo o nome da filósofa por "outros filósofos" ("other philosophers") ("Clouser and Gert expect a strong measure of unity and systematic connection among rules, a clear pattern of justification, and a practical decision procedure that flows from a theory, whereas other philosophers are skeptical of one or more of these conditions, and even of the language of 'theory' - p. 407-8) ${ }^{69}$. Tudo foi mantido na $6^{\mathrm{a}}$. edição (p. 397 $)^{70}$.

A conclusão da $5^{a}$. edição (p. 408), representa uma reescritura da presente na $4^{\text {a }}$. (p. 111), com a inclusão de trecho em que B\&C afirmam que possuem razões para confiar mais em princípios da moralidade comum do que em teorias ("We also have reason to trust principles in the common morality more than theories" - p. 408) $)^{16,69}$. Por sua vez, a da $6^{\text {a }}$. edição (p. 397-8), é a reescritura desta ${ }^{69,70}$.

\section{Alterações da $6^{\mathrm{a}}$. frente à $5^{\mathrm{a}}$. e à $7^{\mathrm{a}}$. edição}

Nesta edição, os capítulos iniciais do livro já contidos na 5a., "Moral Norms" (Normas Morais) e "Moral Character" (Caráter Moral) permaneceram, continuando, inclusive, a compor a Parte I do livro, que agora possui nome: "Moral Foundations" (Fundamentos Morais). A Parte II, ainda contém os capítulos sobre princípios e agora se chama "Moral Principles" (Princípios Morais). Já a Parte III, que agora se intitula "Theory and Method" (Teoria e Método), ainda possui os capítulos "Moral Theories" (Teorias Morais) e "Method and Moral Justification" (Método e Justificação Moral), este agora se chamando apenas "Method and Moral" (Método e Moral). O tópico sobre a Teoria da Moralidade Comum ("Common-Morality Theory"), continuou a estar presente $^{70}$.

$\mathrm{Na}$ antiga $5^{\mathrm{a}}$. edição, se referiam à moralidade comum como um conjunto de normas compartilhadas por pessoas moralmente sérias (p. 3$)^{69} . \mathrm{Na}$ $6^{\text {a }}$. edição, passaram a definir moralidade comum como um conjunto de 
normas compartilhadas por todas as pessoas comprometidas com a moralidade ("The common morality is the set of norms shared by all persons committed to morality" - p. 3$)^{70}$. Na $7^{\text {a }}$., verifica-se que nada mudou (p. 3$)^{18}$.

Ainda na $5^{\mathrm{a}}$. edição, falavam que a moralidade comum contém normas morais que conectam todas as pessoas em todos os lugares, nenhuma das outras normas conseguindo ser mais básica na vida moral. Além disso, que os direitos humanos representavam estas normas morais fundamentais no discurso público até então, não sendo a obrigação moral e a virtude moral partes menos vitais da moralidade comum (p. 3$)^{69}$. Na $6^{a}$., passaram a afirmar apenas que a moralidade comum é aplicável a todas as pessoas em todos os lugares, sendo todas as condutas humanas certamente julgáveis por este modelo ("The common morality is applicable to all persons in all places, and we rightly judge all human conduct by its standards" - p. 3) ${ }^{70}$, o que foi mantido na $7^{a} \cdot(\text { p. } 3)^{18}$.

$\mathrm{Na} 6^{\mathrm{a}}$. edição, incluíram explicação de que algumas pessoas podem ser comprometidas com a moralidade, mas podem agir em discordância com elas; outras pessoas nem mesmo são comprometidas com a moralidade. B\&C citam suas críticas de que construíram uma posição auto-justificável que gira em círculos, criticando que estão definindo a moralidade comum em termos de de um certo comprometimento moral e depois permitindo à apenas aqueles que aceitam suas normas se qualificar como pessoas comprometidas com a moralidade ("Some persons are committed to morality but do not always behave in accordance with their commitments; other persons are not committed to this morality at all [...] Some might conclude that we have constructed a circular and self-justifying position. They might say that we are defining the common morality in terms of a certain moral commitment and then allowing only those who accept the norms that we have identified to qualify as persons committed to morality" - p. 393) ${ }^{70}$. Mantida na $7^{a}$. edição (p. 417) ${ }^{18}$.

$\mathrm{Na} 6^{\mathrm{a}}$. edição, adicionaram exemplos (que não constituem uma lista completa) de modelos de ação (regras de obrigação) encontradas na moralidade comum: não matar, não causar dor ou sofrimento aos outros, 
prevenir o mal ou dano de acontecer, salvar as pessoas em perigo, contar a verdade, ajudar o jovem e o dependente, manter suas promessas, não roubar, não punir o inocente, e obedecer à lei ("The following norms that are examples (though not a complete list) of standards of action (rules of obligation) found in the common morality: (1) Do not kill, (2) Do not cause pain or suffering to others, (3) Prevent evil or harm from occurring, (4) Rescue persons in danger, (5) Tell the truth, (6) Nurture the young and dependent, (7) Keep your promises, (8) Do not steal, (9) Do not punish the innocent, and (10) Obey the law" - p. $3)^{70}$, continuando presentes na edição posterior (p. 3) ${ }^{18}$.

Outra lista meramente exemplificativa está presente a partir da $6^{\mathrm{a}}$. edição, agora, contendo traços de caráter, ou virtudes, da moralidade comum: não-malevolência, honestidade, integridade, conscienciosidade, credibilidade, fidelidade, gratidão, veracidade, amorosidade, delicadeza. Uma pessoa é deficiente de caráter quando não os possui, sendo o vício o oposto das virtudes ("The common morality contains, in addition, standards others than rules of obligation. Here are ten examples (again not a complete list) of moral character traits, or virtues, recognized in the common morality: (1) nonmalevolence, (2) honesty, (3) integrity, (4) conscientiousness, (5) trustworthiness, (6) fidelity, (7) gratitude, (8) truthfulness, (9) lovingness, and (10) kindness [...] A person is deficient in moral character if he or she lacks such traits. Negative traits that are the opposite of these virtues are vices" - p. 3$)^{70}$. Isso foi mantido na $7^{\mathrm{a}}$. edição $(\text { p. } 3)^{18}$.

$\mathrm{Na} 6^{\mathrm{a}}$. edição, B\&C incluíram maiores explicações sobre a moralidade comum, afirmando que não adotam uma concepção ahistórica de moralidade comum, mas são capazes de demonstrar uma maneira não-relativista, ou universalista, de se evitá-la - explicando que não entrarão em maior profundidade nesta discussão moral, apresentando apenas simples esclarecimentos de sua posição. Por isso, explicam que a moralidade comum é um produto da experiência humana, sendo a história um produto universalmente compartilhado; a origem das normas da moralidade comum não é diferente da das normas de moralidades particulares; os autores do Principialismo aceitam o pluralismo moral (que B\&C chamam de relativismo) 
em moralidades particulares, mas rejeitam um pluralismo moral histórico (ou relativismo) dentro da moralidade comum. Para eles, a moralidade comum não é relativa a pessoas ou culturas, porque transcende a ambos; a moralidade comum envolve crenças morais (no que uma pessoa moralmente comprometida acredita) e não modelos antecessores da crença moral; e toda teoria da moralidade comum tem uma história de desenvolvimento feita por seus autores ("We do not embrace an ahistorical conception, but can we demonstrate that there is a nonrelativist, or universalist, way of avoiding ahistoricism? This is an important and complicated problem in moral theory that we cannot engage in depth here. We offer only four simple clarifications of our position: First, we hold that the common morality is a product of human experience and history and is a universally shared product. The origin of the norms of the common morality is no different in principle from the origin of the norms of a particular morality in that [...] Second, we accept moral pluralism (some would say relativism) in particular moralities [...], but we reject a historical moral pluralism (or relativism) in the common morality. The common morality is not relative to cultures or individuals, because it transcends both. Third the common morality comprises moral beliefs (what all morally committed persons believe), not standards prior to moral belief [...] every theory of the common morality has a history of development by the author(s) of the theory" p. 3-4 $)^{70}$. Isso foi mantido na $7^{a}$. edição (p. 4$)^{18}$.

Na $6^{a}$. edição, incluíram anotação de que a moralidade comum pode e deve progressivamente se tornar mais específica - normas morais especificadas certamente se alterarão com o passar do tempo ("Because the common morality can and should be progressively made more specific, specified moral norms are certain to be altered over time" - p. 389) ${ }^{70}$. Mantida na $7^{a}$. edição (p. 412) ${ }^{18}$.

$\mathrm{Na} 6^{\mathrm{a}}$. edição, também incluíram questionamento se as mudanças na moralidade comum se dariam por um processo de subtração ou de adição, possibilidade que parece enfraquecer a ideia de moralidade comum, a menos que seja parte dela própria que novas circunstâncias requeiram sua modificação ("A more interesting question is whether the common morality 
changes by a process of either subtraction or addition [...] the possibility of such change seems to weaken the idea of a common morality, unless it is part of the common morality itself that new circumstances require shifts of belief" - p. 389$390)^{70}$.

Além disso, que tanto deve se requerer na moralidade comum que uma ou mais normas permaneçam intactas ou, ao menos, que a natureza da sua instituição não se altere ("It either would require that one or more moral norms remain unchanged or, at least, would require that the nature of the institution of morality not change" - p. 390 ${ }^{70}$. Na $7^{\text {a }}$. edição, mantiveram as afirmações, contudo, acrescentaram que, na teoria de Gert, mudanças não podem acontecer nas normas da moralidade comum porque as regras morais básicas são tanto essenciais quanto atemporais (p. 412-3) ${ }^{18}$.

Adicionaram, da mesma forma, na $6^{\text {a }}$. edição, que é difícil construir um exemplo sequer atual, ou hipoteticamente plausível, de princípio moral da moralidade comum que tenha sido válido apenas por um tempo limitado. Nada sugere que agora ou no futuro possamos lidar com problemas de profundas mudanças sociais pela alteração das normas na moralidade comum. O mais provável é que continuemos a proceder como sempre, ou seja, na medida em que as circunstâncias forem mudando, achando razões morais para afirmar que existe uma exceção válida para uma norma particular da moralidade comum ("[...] it is difficult to construct even a single actual or plausible hypothetical example of a moral principle in the common morality that has been valid only for some limited duration. Nothing suggests that we do now or might in the future handle problems of profound social change by altering norms in the common morality. It is most likely that we will proceed as we always have: As circumstances change, we will find moral reasons for saying that there is a valid exception to a particular norm in the common morality" - p. 390) ${ }^{70}$. Presente também na $7^{\mathrm{a}}$. edição (p. 413) ${ }^{18}$.

$\mathrm{Na} 6^{\text {a }}$. edição, foi acrescido relato de que já discutiram a tentativa de Bernanrd Gert de justificar a moralidade comum em seu livro "Moralidade: Uma nova justificação das regras morais" ("Morality: A New Justification of the Moral 
Rules"), e, como Gert já demonstrou, de que não há razão para que as normas da moralidade comum não possam ser justificadas por uma teoria ética geral ("We also discussed earlier in the present chapter Bernard Gert's attempts to justify the common morality in his book Morality: A New Justification of the Moral Rules. As Gert has shown, there is no reason why the norms in the common morality cannot be justified by a general ethical theory" - p. 394) ${ }^{70}$. Na $7^{\text {a }}$. edição, repetem isso, mudando o título do livro citado para "Moralidade: Sua natureza e justificação e a Moralidade comum: decidindo o que fazer" (p. $419)^{18}$.

$\mathrm{Na} 6^{\mathrm{a}}$. edição, incluíram explicação de que apenas se não se encontrasse normas em comum nas culturas é que se poderia rejeitar a moralidade comum ("Only if no moral norms were found in common across cultures would the general hypothesis that a common morality exists be rejected" - p. 394 $)^{70}$. Isso foi mantido na $7^{\text {a }}$. edição (p. 418) ${ }^{18}$.

A conclusão, na $6^{a}$. edição (p. $\left.397-8\right)^{70}$, representa apenas uma reescritura da presente na $5^{a}$. edição (p. 408) ${ }^{69}$.

\section{Alterações da $7^{\mathrm{a}}$. frente à $6^{\mathrm{a}}$. edição}

$\mathrm{Na}$ atual $7^{\mathrm{a}}$. edição, na Parte I, os capítulos iniciais do livro, "Moral Norms" (Normas Morais) e "Moral Character" (Caráter Moral) permaneceram, tendo sido adicionado um terceiro: "Moral Status" (Status Moral). Chama a atenção o fato de o capítulo "Moral Norms" (Normas Morais) agora conter um tópico chamado "The Common Morality as Universal Morality" (A Moralidade Comum como Moralidade Universal). A Parte II continuou igual. Já a Parte III, "Theory and Method" (Teoria e Método), ainda possui os capítulos "Moral Theories" (Teorias Morais) e "Method and Moral" (Método e Moral). O tópico sobre a Teoria da Moralidade Comum ("Common-Morality Theory"), continuou a estar presente ${ }^{18}$. 
Nesta edição apenas, afirmam que a moralidade comum sustenta os direitos humanos e outros ideais morais, como caridade e generosidade. Filósofos debatem se algum dos institutos da vida moral (como obrigações, direitos ou virtudes) seriam mais básicos ou mais valiosos do que os outros, mas, na moralidade comum, não há razão para se criar prioridades (" $[. .$.$] the$ common morality supports human rights and endorses many moral ideals such as charity and generosity. Philosophers debate whether one of these regions of the moral life - obligations, rights, or virtues - is more basic or more valuable than another, but in the common morality there is no reason to give primacy to any one area or type of norm" - p. 4) ${ }^{18}$.

$\mathrm{Na}$ anterior $6^{\mathrm{a}}$. edição, explicavam que tanto deve se requerer da moralidade comum que uma ou mais normas permaneçam intactas ou, ao menos, que a natureza da sua instituição não se altere (p. 390) ${ }^{70}$. Na atual, mantiveram esta afirmação, contudo, incluíram que, na teoria de Gert, mudanças não podem acontecer nas normas da moralidade comum porque as regras morais básicas são tanto essenciais quanto atemporais ("In Gert's theory change cannot occur in the norms of the common morality because the basic moral rules are both essential and timeless" - p. 412-3) ${ }^{18}$.

Na $6^{a}$. edição, também havia relato de que já discutiram a tentativa de Gert de justificar a moralidade comum em seu livro "Moralidade: Uma nova justificação das regras morais" (p. 394) ${ }^{70}$. Na $7^{\text {a }}$., repetiram a afirmação, mas mudando o título do livro citado para "Moralidade: Sua natureza e justificação e a Moralidade comum: decidindo o que fazer" ("Morality: Its Nature and Justification and Common morality: Deciding What to Do") ("Earlier in the present chapter we discussed Bernard Gert's attempts to justify the common morality in his book Morality: Its Nature and Justification and Common morality: Deciding What to Do. Gert has effectively shown that there is no reason why the norms in the common morality cannot be justified by a general ethical theory" p. 419$)^{18}$.

$\mathrm{Na}$ atual edição apenas, B\&C não reivindicam que seus quatro princípios formam o âmago moralidade comum de uma forma que outros princípios, 
regras, direitos e virtudes não conseguem. Sua defesa é apenas de que os tiraram da moralidade comum para formular os princípios da Ética Biomédica em sua obra. Ao contrário de Gert, não têm a pretensão de ter removido o véu de todo o conjunto de normas que constituem a moralidade comum. As normas da moralidade comum, sem dúvida, vão além dos princípios sobre os quais se concentram ("We do not claim that our four clusters of principles form the conceptual heart of the common morality in a way that other principles, rules, rights, and virtues do not. Our claim is merely that we draw from the common morality to formulate the principles of biomedical ethics in our book [...] Unlike Gert, we do not claim to have removed the veil from the full set of norms that constitute the common morality. The norms in the common morality undoubtedly reach out beyond the principles on which we concentrate" - $p$. $421)^{18}$.

Nesta última edição, incluíram que nenhuma das teorias éticas disponíveis eliminará a importância da especificação, do balanceamento e do equilíbrio reflexivo como assistentes da prática ética ("[...] no available ethical theory will eliminate the importance of specification, balancing, and reaching for reflective equilibrium as aids in practical ethics" - p. 423) ${ }^{18}$.

$\mathrm{Na} 7^{\mathrm{a}}$. edicão, também acrescentaram explicação de que resultados empíricos poderiam ajudar usando-se o método do equilíbrio reflexivo, em particular, um "equilíbrio reflexivo amplo" ("wide reflective equilibrium"). Além disso que uma forma de se controlar o viés e a falta de objetividade na escolha dos juízos ponderados seria a utilização de informações sobre o que é amplamente, mas, de preferência, universalmente acordado como correto - tipo de informação que pode ser utilizada no procedimento do equilíbrio reflexivo ("[...] empirical findings can assist us in using the method of reflective equilibrium [...] in particular, 'wide reflective equilibrium' [...] One way to control for bias is to use information about what is widely, preferably universally, agreed to be correct. This kind of information can then be employed in the process of reflective equilibrium" - p. 418) ${ }^{18}$. 
$\mathrm{Na}$ conclusão da $6^{\mathrm{a}}$. edição, afirmavam que o método do "working down", ou seja, de aplicação de teorias ou princípios aos casos concretos, era

rejeitado pelos autores do Principialismo (p. 397-8) ${ }^{70}$. Na $7^{\mathrm{a}}$., repetem a ideia de rejeição do método e propoem que poderia ser substituído pelo do equilíbrio reflexivo ("The model of working "down" by applying theories or principles to cases has attracted many who work in biomedical ethics, but we have argued that this model to be replaced by the method of reflective equilibrium" - p. 423$4)^{18}$.

\subsubsection{Análise teórico-conceitual das alterações}

A Teoria da Moralidade Comum foi introduzida na obra de B\&C somente na $4^{a}$. edição. Ela foi utilizada como a própria teoria de fundamentação do Principialismo, o qual sempre careceu de uma própria ou, ao menos, de uma que fosse capaz de organizá-lo enquanto uma teoria propriamente dita.

Nesse diapasão, a $4^{\text {a }}$. edição foi a primeira a tocar neste tema (moralidade comum), assim como em sua teoria ${ }^{16}$ - uma das respostas que $B \& C$ tentaram dar ao longo de sua obra às críticas recebidas, fato, inclusive, reconhecido pelo próprio Childress, no ano de 1994 (mesmo em que publicou a $4^{a}$. edição), em um dos artigos que escreveu sozinho: "Eu fiquei impressionado com o número e a força das críticas [...] as sucessivas edições de PBE refletem o impacto de inúmeras dessas críticas [...]" ("I have been impressed by the number and strength of the criticisms [...] the successive editions of PBE reflect the impact of several of these criticisms $\left.[\ldots]^{\prime \prime}\right)^{1}$.

$\mathrm{Na}$ referida edição, B\&C definiam separadamente "moral" (como convenções sociais sobre condutas humanas certas e erradas tão amplamente compartilhadas que formam um consenso comunitário estável, todavia, normalmente incompleto), e "ética" (como um termo geral que tanto se referiria à moralidade quanto à teoria ética - p. 5-6 $)^{16}$. Na edição seguinte, continuaram apenas definindo o que era moral (p. 3$)^{69}$, subentendendo-se que os autores passaram a não mais a explicitar uma separação entre os dois conceitos. 
$\mathrm{Na}$ mesma $4^{\mathrm{a}}$. edição, uma definição inicial de moralidade comum foi dada: "uma compilação de normas de conduta humana socialmente aprovadas" ("[...] the common morality comprises socially approved norms of human conduct" - p. 6) ${ }^{16}$. Conceito que, na edição subsequente, passou a um "conjunto de normas compartilhadas por pessoas moralmente sérias" ("[...] set of norms that all morally serious persons share as the common morality" - $p$. $3)^{69}$. Na $6^{a}$. edição B\&C voltaram a modificar seu conceito de moralidade comum, agora definindo como um "conjunto de normas compartilhadas por todas as pessoas comprometidas com a moralidade" ("The common morality is the set of norms shared by all persons committed to morality" - p. 3) ${ }^{70}$. Na $7^{\mathrm{a}}$. (p. 3), mantiveram este conceito ${ }^{18}$.

Como se pode perceber, a mudança de entendimento dos autores do Principialismo sobre o que seria a moralidade comum não foi em vão. Ao reduzirem seu âmbito de abrangência a determinados grupos, primeiramente ao das pessoas moralmente sérias, depois, ao das pessoas comprometidas com a moralidade, tornaram mais fácil justificar sua pretensa universalidade, pois não se aplicaria mais a todos indistintamente, mas apenas a prédeterminados grupos, escolhidos pelos autores ${ }^{50,73}$.

Assim, cada vez mais, B\&C foram distanciando sua concepção de moralidade comum da inicialmente proposta por Gert e Clouser, que a definiam como um conjunto de regras morais universais endossadas por todos os agentes morais racionais (p. 73) ${ }^{74}$. Bem verdade é que este sentido coletivo de moralidade não se identifica com a origem da palavra moral. Segundo Donagan, a moralidade vem de "mores" (p. 01), que se refere a normas de conduta individual, sendo a moralidade nada mais do que um sistema de "mores". Todavia, a moralidade, para os filósofos moralistas, acabou assumindo significado diverso, como algo lastreado pela virtude e que influencia as escolhas pessoais ${ }^{71}$.

$\mathrm{Na} 7^{\mathrm{a}}$. edição, fato interessante que pode ser percebido no contexto da organização geral da obra é que a palavra "moral", quase que ausente nos 
títulos de capítulos das edições anteriores, passou a ser uma constante. Excetuando os capítulos referidos especificamente aos quatro princípios e o sobre a relação profissional-paciente, os quais mesmo assim se situam na Parte II, intitulada "Moral Principles" (Princípios Morais), todos os demais capítulos contêm a palavra "moral" nos seus títulos ${ }^{18}$. Isso chama especialmentre à atenção porque moral diz respeito a costumes, hábitos de um povo, de uma determinada população ${ }^{71}$. Assim, essa referência à "moral" está relacionada com o pluralismo (segundo $B \& C$, o mesmo que relativismo), e não com o universalismo que eles tentaram defender desde os primórdios do Principialismo.

Em busca de justificar esta universalidade, B\&C acabaram por confundir (de maneira proposital talvez) os tipos de universalismo em ética. Percebe-se que os autores partiram da defesa de uma universalidade no sentido de todos terem a mesma moralidade comum (a qual não conseguiram sustentar) para a defesa de uma onde todos possuem uma moralidade comum, mesmo que cada um tenha a sua ${ }^{71}$. Por isso mesmo que, na $5^{\mathrm{a}}$. edição, B\&C esclarecem que mantiveram no passado a existência de uma única moralidade comum universal (p. 403) ${ }^{69}$. Nesta mesma edição, também reconhecem a existência de mais de uma Teoria da Moralidade Comum, como a dos autores Ross e Frankena (p. 403) ${ }^{69}$.

Não só nesta edição ${ }^{69}$, mas nas seguintes, $6^{\mathrm{a}} \cdot(\text { p. 393 })^{70}$ e $7^{\mathrm{a}} \cdot(\text { p. } 417)^{18}$, deixam isso claro ao afirmar que algumas pessoas concluem que eles construíram uma posição auto-justificável que gira em círculos, criticando que estão definindo a moralidade comum em termos de certo comprometimento moral e depois permitindo a apenas aqueles que aceitam suas normas se qualificar como pessoas comprometidas com a moralidade. Justamente o que Herissone-Kelly segue criticando, ou seja, o modo como os autores do Principialismo trabalham o tema da moralidade comum. $O$ autor defende que, empiricamente, B\&C não são capazes de apresentar uma única moralidade comum universal, mas diversas moralidades comuns e, mais do que isso, apenas aplicáveis a determinados grupos morais ${ }^{50}$. 
Curioso que, na mesma $5^{\mathrm{a}}$. edição em que reconheceram a existência de diversas moralidades comuns e de diversas de suas teorias, apenas nesta, ainda na esperança por justificar a pretensa universalidade da moralidade comum dentro do Principialismo, B\&C disseram que, mesmo em comunidades com costumes peculiares, pode-se identificar a moralidade comum nos preceitos mais fundamentais (p. 4-5) ${ }^{69}$. Onde B\&C buscam amparo (mesmo que implicitamente) no que Donagan nomeava de predicados definidos e nãodefinidos; estes, mais primitivos, e, por conseguinte, universais, enquanto aqueles, já mais especificados, ou seja, mais próximos da aplicabilidade prática, não possuindo alcance universal ${ }^{71}$. Assim, $B \& C$ tentam ainda justificar que no âmbito mais fundamental (dos predicados não-definidos) ainda existiria algo de sua tão buscada universalidade.

Na mesma $5^{\mathrm{a}}$. edição, B\&C buscaram apontar sinais de convergência entre as várias teorias da moralidade comum (p. 4-5 ${ }^{69}$, quase que defendendo um nível universal de moralidade comum dentro das próprias moralidades comuns. Mais uma demonstração de que B\&C não alcançam justificar a universalidade da moralidade comum da maneira como primeiramente tentaram e, agora, tentam reduzi-la tanto em nível de fundamentação quanto em seu âmbito de aplicabilidade.

Gordon, assim como Rauprich e Vollmann, no entanto, preferem socorrer os autores do Principialismo. Os autores esclarecem que B\&C apenas continuam tentando solucionar as críticas recebidas de forma empírica, argumentando que a moralidade comum representa sim um conjunto de normas comprovadamente úteis no alcance dos objetivos da moral ${ }^{47,48}$. Porém, o que se percebe é que estes autores (Gordon, Rauprich e Vollmann) não auxiliam no esclareceminto das ideias truncadas apresentadas por B\&C, assim como não apresentam as reais intenções dos dois autores. Nota-se que defendem o Principialismo por sua utilidade, e nunca por sua coerência e sustentação teórica.

Os próprios $B \& C$, ainda na $4^{a}$. edição, já explicavam que nem mesmo a moralidade comum seria completa, ou mesmo isenta de falhas (p. 6$)^{16}$. Outra 
tentativa de se esquivar das críticas, pois a grande questão não reside na aplicabilidade prática do Principialismo, mas sim na maneira como foi trabalhado. Da mesma forma, esta busca por um universalismo foi realizada por Kukla ${ }^{75}$, o que, de acordo com Strong (p. 99), seria inócua, uma vez que a moralidade comum não precisa de uma aceitabilidade universal, mas sim de uma aplicabilidade universal ${ }^{73}$, ou seja, não importa sua natureza, mas sim a maneira como será utilizada na prática.

Holm e também Luna alegam que, apesar da grande mudança que foi a introdução da moralidade comum na $4^{a}$. edição, foi, a partir da $5^{a}$. que os autores do Principialismo passaram a responder mais enfaticamente às críticas que vinham sofrendo desde a edição inaugural, o que provocou, inclusive, mudanças de conteúdo na obra ${ }^{15,39}$. Talvez porque, apenas nessa $5^{a}$. edição, B\&C chegaram a afirmar que irão apresentar sua própria versão da Teoria da Moralidade Comum e que não farão nenhuma tentativa de apresentar ou justificar uma teoria ética geral, apenas se preocupando com a vertente da moralidade comum assumida por eles, voltada a questões de método e justificação em Ética Biomédica (p. 403) ${ }^{69}$.

Porém, na verdade, o que se vê é que foi desde a própria $4^{a}$. edição, e de forma crescente nas seguintes, que $B \& C$ reforçaram a ideia de prescindibilidade de uma teoria ${ }^{16}$. Isso, porque Clouser e Gert, ao esperar de uma teoria, grande unidade e sistemática conexão entre regras, um claro modelo de justificação e um procedimento prático de decisão, passaram a criticar o Principialismo a partir de 1990, ou seja, entre a publicação da $3^{a}$. e da $4^{a}$. edição da obra ${ }^{6}$.

Nesta $4^{a}$. edição (p. 109) ${ }^{16}$, B\&C citavam a filósofa Baier, a qual é cética em relação a cada uma das condições da teoria que Gert e Clouser defendem (grande unidade e sistemática conexão entre regras, um claro modelo de justificação e um procedimento prático de decisão). A partir da $5^{a}$. edição (p. 407-8), continuaram a fazer a referência, contudo, excluindo o nome da autora - trocando pela expressão "outros filósofos" 69 . Esta citação, assim como a inclusão de "outros filósofos" no lugar de apresentar apenas uma, denota a 
vontade de B\&C de mostrar que não estão sozinhos, ou mesmo pouco acompanhados, em sua defesa da prescindibilidade de um corpo teórico de justificação moral.

Diante deste contexto, os próprios B\&C se referiram ao Principialismo como uma das "filosofias morais" ("moral philosophies" - p. 401-3), e não como uma teoria, na $5^{\text {a }}$. edição ${ }^{69}$. Contudo, se referem assim não apenas à sua obra, mas às teorias de Frankena e Ross, talvez como uma maneira de afastar o conceito de teoria e de, ao mesmo tempo, colocar a sua obra, que não é uma teoria, no mesmo patamar de duas já consagradas da Filosofia.

Ainda na tentativa de provar que uma teoria não é algo imprescindível, na mesma $5^{a}$. edição, B\&C incluíram a afirmação de que muitos autores passam a impressão de que apenas uma teoria poderia solucionar os conflitos morais, complementando que, na verdade, nenhuma delas consegue de maneira direta e incontroversa passar da teoria à prática, mesmo dentre pessoas que adotam a mesma teoria (p. 404-5) ${ }^{69}$.

De maneira contraditória, na $6^{\text {a }}$. edição, $\mathrm{B} \& \mathrm{C}$ voltam a defender a Teoria da Moralidade Comum na concepção de Gert e Clouser, assim como seu uso enquanto teoria válida. Mas, não apenas voltam atrás nestas duas defesas, como também retornam a apoiar a possibilidade de um universalismo na moralidade comum nos mesmos moldes que defenderam inicialmente - ou seja, onde todos compartilhariam a mesma moralidade ${ }^{70}$.

Fato curioso é que Gert foi convidado a fazer uma declaração na contracapa da $6^{\text {a }}$. edição, onde reconhece que a obra de B\&C, mais do que qualquer outra, auxiliou na delimitação do campo de atuação da Ética Biomédica, assim como que a referida edição da obra conseguiu ser ainda melhor do que as cinco anteriores ${ }^{70}$. No entanto, faz uma ressalva dizendo que ainda tem alguns receios com relação à ideia de "Teoria do Principialismo", explicando que não possui nada além de admiração pela detalhada e abrangente discussão dos problemas morais que emergem no campo da Medicina. Finaliza declarando que pretendia fazer uso da $6^{a}$. edição, da mesma 
forma que já o fez com as anteriores, como uma das principais literaturas de base em seu curso de Filosofia da Medicina ${ }^{70}$.

Já na $7^{a}$. edição, a declaração do mesmo Gert da contracapa é diferente. Nela, o autor continua reconhecendo a importância da edição anterior, porém, esclarece que B\&C continuam escutando as críticas sofridas, inclusive as do próprio Gert, e alterando sua obra de acordo com elas. Termina, mais uma, vez, afirmando que ainda não está totalmente convencido da ideia de uma "Teoria do Principialismo", embora reafirme sua admiração pela obra ${ }^{18}$.

Na $6^{\text {a }}$. (p. $\left.3-4\right)^{70}$ e na $7^{\text {a }}$. edição (p. 4$)^{18}$, B\&C esclarecem que aceitam o pluralismo moral (como sinônimo de relativismo...) nas moralidades particulares, mas que rejeitam o pluralismo moral histórico na moralidade comum, eis que a moralidade comum não é respectiva a pessoas ou culturas, porque transcende a ambas.

Na $7^{\text {a }}$. edição, B\&C tentam se explicar novamente, agora dizendo que não apenas não se apropriaram da Teoria da Moralidade Comum, como também nunca tentaram fazer de seus quatro princípios o seu âmago. Segundo eles, recorreram à moralidade comum para formular seus princípios de Ética Biomédica, apesar de as normas da moralidade comum irem além dos princípios sobre os quais se concentraram no Principialismo (p. 421) $)^{18,76}$.

Apenas na $5^{a}$. edição $B \& C$ haviam dito algo parecido, pois, de acordo com eles, as teorias apenas tentariam capturar o ponto de vista moral, sendo a moralidade a âncora da teoria, e não o contrário (p. 405) ${ }^{69}$. Chegaram a afirmar que, se uma teoria ética rejeitasse qualquer dos quatro princípios defendidos em sua obra, eles teriam razões para duvidar da teoria, e não dos princípios ( $p$. $405)^{69}$, admitindo confiar mais em princípios do que em teorias - talvez porque o próprio Principialismo não consiga ser uma.

Mas, não apenas pela falta de uma teoria do principialismo é que Gert e Clouser são mencionados por B\&C. Além desta crítica, outras deles são trazidas (apenas) na $4^{\mathrm{a}}$. edição: que o Principialismo não passaria de um 
"mantra de princípios", insinuando haver pouca reflexão a respeito deles; que os princípios são pouco mais que check-lists para valores importantes, sem conteúdo moral substancial ou capacidade de guia de ação; e que seus princípios são prima facie e a sua justificação é incapaz de determinar um procedimento de decisão (p. 106) ${ }^{16}$. Os dois críticos ressaltaram também a falta de um procedimento claro de solução de conflitos entre princípios no Principialismo ${ }^{16}$. B\&C rebatem estas afirmações na mesma $4^{\mathrm{a}}$. edição dizendo que a priori não são mesmo questões solucionáveis e que nenhum sistema de guias de ação poderia razoavelmente antecipar um completo rol de conflitos ( $p$. $107)^{16}$. Na visão deles, representa uma virtude o Principialismo requerer especificação, ou seja, complementação, e um defeito a teoria de Gert e Clouser, por meio de regras, escapar disso (p. 107) ${ }^{16,76}$.

Certo é que $B \& C$, apesar das transformações que promoveram em sua obra, não conseguem explicar convenientemente qual seria a metodologia clara de aplicação dos princípios. Beauchamp, em um artigo que publicou sozinho em $2014^{76}$, ao tentar rebater as críticas de Kukla ${ }^{77}$ sobre o assunto, mais uma vez, expõe a fragilidade do Principialismo, quando não apresenta um método, mas apenas exemplos de onde ele não poderia ser aplicado, como em relações de confiança e com animais em pesquisa laboratorial, dentre outras $(\text { p. } 87)^{76}$.

Já na $7^{\text {a }}$. edição, B\&C incluíram que nenhuma das teorias éticas disponíveis eliminará a importância da especificação, do balanceamento e do equilíbrio reflexivo (todas estas são formas de complementação de princípios) como assistentes da prática ética (p. 423) ${ }^{18}$.

Ainda na $6^{\text {a }}$. edição, B\&C rejeitaram o método do "working down", ou seja, de aplicação de teorias ou princípios aos casos concretos, propondo, na $7^{a}$., em especial, o uso de um equilíbrio reflexivo "amplo" (p. 397 $)^{70}$. Este método criado por Rawls consiste em um conjunto de julgamentos morais, princípios morais e de teorias de fundo, os quais devem ser "balanceados", ou seja, devem ser confrontados uns contra os outros na busca de uma solução moral equilibrada ${ }^{22,72,73}$. No Principialismo, isso funcionaria como uma forma de 
controlar o viés e a falta de objetividade na escolha dos juízos ponderados, utilizando-se de informações sobre o que é amplamente, mas, de preferência, universalmente, acordado como correto ${ }^{70}$. Para Strong, contudo, mesmo este método não serviria ao que o Principialismo propõe; por ser parte de um conjunto de considerações morais particulares que então buscará o conjunto de princípios aplicáveis (o que se faria até encontrar uma solução equilibrada), o método não poderia funcionar como justificação forma de pessoal ${ }^{73}$.

Assim, percebe-se que B\&C não apenas rebateram a crítica da falta de uma teoria própria do Principialismo, mas que, nas entrelinhas, rebateram também a crítica da falta de um procedimento claro para lidar com conflitos entre princípios. Contudo, agora apropriando-se da Teoria da Justiça de Rawls, tal qual fizeram com a Teoria da Moralidade Comum de Clouser e Gert ${ }^{22,72}$.

\subsection{Com relação ao Princípio da Justiça}

\subsubsection{Alterações ao longo das edições}

\section{Alterações da $2^{\mathrm{a}}$. frente à $1^{\mathrm{a}}$. edição}

O capítulo sobre o Princípio da Justiça existe desde a $1^{\text {a }}$. edição da obra, com os tópicos "The Concept of Justice" (O Conceito de Justiça), "Material Principles of Justice" (Princípios Materiais de Justiça), "Relevant Properties" (Propriedades Relevantes), "Fair Opportunity" (Oportunidade Justa), "Macroallocation" (Macroalocação) e "Microallocation" (Microalocação) $^{31}$. Tais tópicos continuaram presentes na $2^{a}$. edição, com a única diferença de que o "Macroallocation" (Macroalocação) passou a ser chamado de "Macroallocation and Health Policy" (Macroalocação e Política de Saúde $)^{68}$.

$\mathrm{Na} 1^{\text {a }}$. edição, ao falarem sobre o princípio da justiça formal, ou da igualdade formal, ou da equidade, o explicavam conceituando ${ }^{31}$ - o que foi excluído na edição seguinte, a qual somente teve mantida a definição do que 
seria "iniquidade" (p. 184-5) ${ }^{68}$. Assim, definiam equidade como "...indivíduos que são iguais nos seus aspectos relevantes deveriam ser tratados igualmente, enquanto indivíduos que são desiguais nos aspectos relevantes deveriam ser tratados de forma diferente na proporção de suas diferenças" ("[...] individuals who are equal in the relevant respects should be treated equally, while individuals who are unequal in the relevant respects should be treated differently in proportion to the differences" - p. 171-2) ${ }^{31}$.

$\mathrm{Na}$ edição inaugural, afirmavam que os utilitaristas defendem que os provedores de saúde fazem (ou deveriam fazer) as decisões de alocação baseadas no valor social ("Some defenders of utilitarian selection invoke the model of triage to show that health care providers do and should make allocate decisions based on social worth" - p. 197) ${ }^{31}$. Quanto às decisões que não envolvem os valores sociais das pessoas, seriam, segundo B\&C, baseadas na urgência e na necessidade médica ("Such a classification in terms of urgency of medical need establishes priorities of treatment that do not involve judgments about social worth" - p. 197) ${ }^{31}$. Também, que critérios objetivos de escolha de sujeitos de pesquisa reduzem as pessoas aos seus papéis socialmente valorados ("[...] objective criteria could be fairly applied, it is not clear that they could be adequately justified [...] Such criteria seem arbitrarily selected and also tend to reduce persons to their socially valued roles" - p. 196) $)^{31}$.

$\mathrm{Na} 2^{\mathrm{a}}$. edição, ao contrário de tudo isso que havia na $1^{\mathrm{a}}$., passaram a criticar que os critérios objetivos de escolha de sujeitos de pesquisa, mesmo sendo objetivos, parecem mais subjetivamente calcados do que objetivamente, o que não se confunde com critérios arbitrários. Assim, não sendo arbitrários, podem sim ser reduzidos a critérios médicos ou utilitários - e não apenas ao papel social de cada sujeito, como se declarou na $1^{\text {a }}$. edição (p. 213-4) ${ }^{68}$.

Ainda na $1^{\mathrm{a}}$. edição, em questionamento sobre quais classes de pessoas poderiam participar de ensaios clínicos, como prisioneiros, fetos, crianças e institucionalizados por doenças mentais, incluíam a possibilidade de se afastar pessoas não pertencentes a nenhuma destas classes, mas que apresentavam qualquer outra característica moralmente relevante. Nesse sentido, citavam o 
caso de uma criança com perna amputada que não deveria participar de uma pesquisa sobre coordenação motora com exercícios que seriam muito difíceis para ela executar ("For example, a child with an amputated leg might be excluded from research on children that involves tests of coordinative skills that are to difficult for this individual child" - p. 181-2) ${ }^{31}$.

$\mathrm{Na} 2^{\mathrm{a}}$. edição, porém, trouxeram a posição de uma associação e de um periódico científico sobre a possibilidade, ou não, de deficientes mentais participarem de pesquisas clínicas. A associação defendia que nenhuma pesquisa clínica poderia ser feita com deficientes mentais, a não ser que estivesse diretamente relacionada com a etiologia, patogênese, prevenção, diagnóstico ou tratamento da doença em si (p. 196-7) ${ }^{68}$.

Já, para o periódico, estas pesquisas seriam muito importantes à compreensão da hepatite, assim, potencialmente valiosas às próprias crianças da instituição, não havendo prejuízos a elas porque provavelmente contrairiam hepatite de qualquer jeito, além disso, teriam sido realizadas por competentes pesquisadores (p. 196-7) ${ }^{68}$. Nas duas primeiras edições (p. 184 e p. 197-8, respectivamente $)^{31,68}$, se referiam a pessoas com deficiência como pessoas com "vagarosidade" ("slowness").

$\mathrm{Na} 1^{a}$. edição, afirmavam que, se os recursos não fossem escassos, os médicos deveriam afastar das pesquisas apenas aquelas pessoas que não se beneficiariam dela ("If physicians made scarcity irrelevant to their determination of the initial pool, they would exclude only those candidates who could not possibly benefit from the treatment" - p.194) ${ }^{31}$. Comentário plenamente mantido na $2^{a}$. edição (p. 212) ${ }^{68}$.

$\mathrm{Na} 1^{\text {a }}$. edição, também começaram a tecer os primeiros comentários sobre a regra da justa oportunidade ("fair opportunity rule"), em que, se uma pessoa não é responsável pela desvantagem física ou social que apresenta na sociedade, ela não deve ser privada de benefícios por isso ("[...] whenever a person is not responsible for certain 'disadvantageous' properties, he should not 
be denied important benefits because he possesses those properties" - p. $186)^{31}$, o que foi conservado na edição seguinte (p. 199-200 $)^{68}$.

Também explicavam, mas apenas na $1^{\text {a }}$. edição, que, quando uma pessoa possui benefícios dados pela sociedade, ela também incorre em obrigações frente a esta, em reciprocidade. Contudo, se uma pessoa não pode, sem ser por sua culpa, cumprir com a contraprestação, deve-se abrir uma exceção ("When a person receives benefits conferred by society, he incurs reciprocal obligations to the society [...] Where persons cannot reciprocate, through no fault of their own, we apparently make an exception to this reciprocity thesis" - p. 184-5) ${ }^{31}$.

Sobre a regra da justa oportunidade, já na $1^{\mathrm{a}}$. versão da obra, esclarecem que se baseia na justiça, e não nos pilares da justiça distributiva os quais são mérito, esforço e contribuição ("[...] presupposes as appropriate a set of principles of distributive justice (such as merit, effort, and contribution) which in fact are declared inappropriate by the fair opportunity principle" - $p$. $185)^{31}$, o que foi mantido na $2^{\mathrm{a}}$. edição (p. 185) ${ }^{68}$.

$\mathrm{Na}$ inaugural, relatavam que alguns critérios psicológicos podem ser também medicamente relevantes ("Some psychological factors may also be medically relevant [...]" - p.194) ${ }^{31}$, esclarecendo o que seria a teoria causal das origens das vantagens e desvantagens ("theory of the causal origins of advantageous and disadvantageous properties") a serem consideradas na justa distribuição, onde se procura a responsabilidade de cada um sobre suas desvantagens físicas e sociais para saber se tem direitos a benefícios ("[...] whenever a person is not responsible for certain "disadvantageous" properties, he should not be denied important benefits because he possesses those properties [...] If this theory of the causal origins of advantageous and disadvantageous properties were accepted [...] then one would be led to radically different views about distributive justice [...]" - p. 186) ${ }^{31}$.

Todos este argumentos também se encontram na $2^{a}$. edição, porém, passando a discutir o exemplo dos fumantes e dos alcoolistas, que poderiam 
ser responsáveis, ou não, pelas doenças resultantes de seus hábitos deletérios, o que, como consequência, poderia acarretar (ou não) o direito à assistência de saúde pública (p. 200-1) ${ }^{68}$.

Iniciaram, na exordial, questionamentos sobre se o Estado deveria investir mais recursos em medicina curativa ou em preventiva ("Should society concentrate on rescue strategies [...] or should society concentrate on the prevention of disease and disability?" - p. 190) ${ }^{31}$, os quais foram ampliados na $2^{\text {a. }}$ (p. 196-7, 203, 204-5 e 207) ${ }^{68}$.

Iniciaram também, na $1^{\text {a }}$. edição, discussão sobre a possibilidade de alguém receber tratamento pago pela sociedade por doença que adquiriu por hábitos deletérios voluntários, atitude que, muitas vezes, eleva o que deve ser pago por pessoas que talvez nem utilizem o sistema de saúde ("[...] citizens will argue that it is unfair to increase their premiums or taxes to pay for the avoidable, self-caused afflictions of others" - p. 191 ${ }^{31}$. Outra que foi expandida na $2^{\mathrm{a}}$., contudo, "aflições autocausadas" ("self-caused afflictions"), ou hábitos deletérios, como costumamos falar em português, passaram a ser referidas como "condutas de risco" ("risky conducts" - p. 207 e 208) ${ }^{68}$.

Havia citação, apenas na edição inicial, que descrevia que as políticas públicas de saúde consideram a saúde como um bem de consumo a ser alocado primordialmente por decisões de cunho privado e mercadológico, em um mercado que protege os mais poderosos ("The preponderance of our public policy for health continues to define health care as a consumption good to be allocated primarily by private decisions and markets, and only interferes [...] Market justice is a pervasive ideology protecting the most powerful [...]' - p. $191)^{31}$.

Também apenas nesta edição, citavam Kennan quando trata de seu princípio da "total ambiguidade da responsabilidade" ("total ubiquity of responsibility"), onde o estabelecimento de papéis na sociedade se mostra importante à divisão de responsabilidades, relatando que as obrigações dos médicos não são iguais às dos que elaboram as políticas de saúde (“[...] 
George Kennan calls 'the principle of the total ubiquity of responsibility', it is appropriate to structure social roles so that there is a division of responsibility [...] not suppose that the physician's obligations are identical with those of the policymaker" - p. 196) ${ }^{31}$.

\section{Alterações da $2^{\mathrm{a}}$. frente à $1^{\mathrm{a}}$. e à $3^{\mathrm{a}}$. edição}

O capítulo sobre o Princípio da Justiça, nesta $2^{\mathrm{a}}$. edição, mudou, do ponto de vista macroestrutural, pouco em relação à anterior. Os tópicos "The Concept of Justice" (O Conceito de Justiça), "Material Principles of Justice" (Princípios Materiais de Justiça), "Relevant Properties" (Propriedades Relevantes), "Fair Opportunity" (Oportunidade Justa), "Macroallocation" (Macroalocação) e "Microallocation" (Microalocação) continuaram presentes, com a única diferença de que o "Macroallocation" (Macroalocação) passou a ser chamado de "Macroallocation and Health Policy" (Macroalocação e Política de Saúde $)^{68}$.

$\mathrm{Na} 2^{\mathrm{a}}$. edição, incluíram explicação sobre o foco de cada uma das teorias da justiça: Igualitária (igual acesso a bens que todos desejam); Marxista (necessidade); Libertária (direito à liberdade social e econômica segundo critérios de contribuição e mérito); e Utilitária (combinação de utilidade pública e privada maximizadas). Sendo a escolha de cada depende do que se desejaria dar prioridade ("Egalitarian theories emphasize equal access to the goods in life that every rational person desires; Marxist theories emphasize need; Libertarian theories emphasize rights to social and economic liberty (implicitly invoking criteria of contribution and merit); and Utilitarian theories emphasize a mixture of criteria so that public and private utility is maximized [...] one or more selected material principles ought to be given priority [...]" - p. $188-9)^{68}$. Parte que, na $3^{a}$. edição, ganhou todo um capítulo sobre o assunto ( $p$. $265-70)^{17}$.

Nesta $2^{\mathrm{a}}$. edição, também incluíram que a alocação em Biomedicina é um exemplo de "problema substancial de justiça social" ("We can then pass on 
to more substantive problems about social justice, including problems in the allocation of biomedicine" - p. 183) ${ }^{68}$, mantido na $3^{\text {a }}$. edição (p. 256) ${ }^{17}$.

Passaram também a citar Rawls, o qual já era expressamente mencionado nas edições anteriores em outras passagens, quando este afirma ser um dos filósofos que defende que a justiça pode ser mais bem explicada em termos do que seria "justo" ("fairness"). Ao mesmo tempo em que B\&C defendem que talvez o conceito mais próximo de justiça no seu sentido mais amplo seja "mérito" ("desert"), dando a cada um o que é seu ou de direito ("Some moral philosophers, most notably John Rawls, have argued that justice is best explicated in terms of fairness [...] perhaps the concept most closely linked to justice in its broadest sense is desert" - p. 184) ${ }^{68}$, mantendo apenas a segunda parte na $3^{\text {a }}$. edição (p. 257 $)^{17}$.

$\mathrm{Na} 2^{\mathrm{a}}$. edição, ao falarem sobre justiça distributiva e esclarecerem que ela é uma apropriada distribuição de "ônus" e "bônus" (o que já dito na $1^{\text {a }}$. edição - p. 169) ${ }^{31}$, passaram a explicar que ela é composta por uma série de regras morais, legais e culturais e de princípios, chamados de "termos de cooperação de uma sociedade" ("terms of cooperation for that society"), cláusulas implícitas e explícitas que obrigam os indivíduos a cooperar mutuamente ("This distribution is conceived as a cooperative enterprise structured by various moral, legal, and cultural rules and principles [...] may be called the terms of cooperation for that society; they are the implicit and explicit terms under which individuals are obligated to cooperate" - p. 184) ${ }^{68}$. Trecho mantido na $3^{\text {a }}$. edição (p. 258) ${ }^{17}$.

Explicaram também somente até a $2^{\mathrm{a}}$. edição, e tal qual havia na $1^{\mathrm{a}}$. ( $\mathrm{p}$. $170)^{31}$, que a justiça distributiva só se fazia necessária em situações de escassez ("The point is that there is no need for principles of distributive justice until some measure of scarcity exists" - p. 185) ${ }^{68}$.

Somente na $2^{\mathrm{a}}$. edição, afirmavam que regras de justiça distributiva como mérito, sacrifício e contribuição, são inapropriadas onde regras de justa oportunidade devem ser aplicadas, como no caso das pessoas que não fizeram 
nada para ficarem doentes e também merecem tratamento ("Rules of distributive justice such as merit, effort, and contribution are irrelevant in these contexts, because they are excluded as inappropriate by the fair opportunity principle. Of course we can still say that such persons "deserve" the treatment they receive. They deserve it because it is fair" - p. 198-9) ${ }^{68}$.

Apesar de ter retirado o conceito de equidade da obra, antes presente na $1^{a}$. edição (p. 171-172) ${ }^{31}$, mantiveram, exclusivamente na $2^{a}$. edição, a explicação do que seria a "iniquidade", como sendo as disparidades das garantias que deveriam assegurar o valor igual de todas as pessoas ("[...] most societies proclaim the equal worth of all persons and back that proclamation with various legal guarantees of equal justice and rights, economic and political disparities between individuals in those societies (and internationally between nations) are ubiquitous. These disparities are often labeled 'inequities [...]" p.184-5) $)^{68}$.

Da mesma forma, na $2^{a}$. edição, começaram a tratar do tema da escassez de recursos, já o incluindo no título que trata da justiça comparativa: "Comparative justice and the problem of scarce resources" (p. 185) ${ }^{68}$. Excepcionalemnte nesta edição, sobre a justiça comparativa, explicaram que existe quando se determina o que uma pessoa merece por meio da comparação com outras; e, não-comparativa, quando se determina pelas condições da pessoa em si ("Justice is comparative when what one person deserves can be determined only by balancing the competing claims of other persons against his or her claims [...] Justice is noncomparative, by contrast, when desert is judged by a standard independent of the claims of others" - $\mathrm{p}$. $185)^{68}$.

Também, sobre a justiça comparativa, somente na $2^{a}$. edição, citavam Hume quando explica que foi criada para lidar com conflitos relacionados à escassez ("David Hume pointed out that the concept of comparative justice has been developed in order to handle problems of conflicting claims or interests [...] rules of justice would have no point unless society were composed of 
persons with limited sympathy for others in the competition for scarce resources" - p. 185-6) ${ }^{68}$.

Desde a $1^{\text {a }}$. edição (p. 194-5) ${ }^{31}$, já havia a explicação presente na $2^{\mathrm{a}}$. de que, em situações de escassez, a igualdade deveria ser entendida como "igualdade de oportunidade" ("equality of opportunity") porque nem todos podem ser tratados de maneira igual ("Equality" should be here construed as "equality of opportunity", because not everyone can be treated identically" - p. $214)^{68}$.

Já, na $3^{a}$. edição, explicam que a justa distribuição de assistência à saúde seria baseada, na verdade, em um princípio de "justa igualdade de oportunidade" ("fair equality of opportunity") ("[...] just distribution of health care is based centrally on a principle of needs and seeks to achieve 'fair equality of opportunity'[...]' - p. 269-70) ${ }^{17}$.

A partir da edição inaugural (p. 170-1 e 202-3) ${ }^{31}$, B\&C discutem se o governo deveria investir na pesquisa de coração artificial para implante ou nos transplantes de coração propriamente ditos, o que foi mantido na $2^{a}$. edição: "[...] whether to provide federal funds to produce the totally implantable artificial heart and whether to subsidize cardiac transplantation" (p. 202-3) ${ }^{68}$. Na $3^{a}$. edição, mantiveram os comentários (p. 258-9), mas também afirmaram que muitas questões sobre os transplantes de coração surgiram por causa de seus elevados custos, muito além do que muitas pessoas podem pagar, apesar de alguns planos cobrirem (p. 285) $)^{17}$.

$\mathrm{Na} 2^{\mathrm{a}}$. edição, incluíram afirmação de que escolhas trágicas na microalocação podem levar a sociedade, por meio dos governos, a alterar suas políticas de macroalocação, com vista a suprir os recursos escassos ("[...] 'tragic choices' in microallocation may lead the society, through the government, to alter its macroallocation policies in order to increase the supply of the scarce resource [...]' - p. 209-10) ${ }^{68}$. O que foi excluído na $3^{a}$. edição, que, contudo, passou a citar Daniels, que define nível macro como sendo o que abrange o alcance e a forma das instituições básicas de saúde, as instituições centrais e 
as práticas sociais que formam um verdadeiro sistema de saúde, além de definir o que as decisões em nível macro determinariam (p. 283-4) ${ }^{17}$.

$\mathrm{Na} 2^{\mathrm{a}}$. edição, acrescentaram discussão sobre a dificuldade de estabelecer o que seria "um direito à assistência de saúde" ("a right to medical care") ${ }^{68}$, afirmando que dois grandes direitos estariam incluídos: igual acesso à assistência e direito ao mínimo existencial - este é o nome pelo qual é mais conhecido (nomenclatura aqui adotada), apesar de a $4^{a}$. edição traduzida para o português ter optado pela tradução mais literal de "mínimo digno" (p. 375) ${ }^{78}$ ("It has been difficult to specify a right to medical care, but two major views are (1) that there is a right to equal access to medical care, and (2) that there is a right to a decent minimum of medical care" - p. 203-4) $)^{68}$. Na $3^{a}$. edição, porém, afirmam também que, muitas vezes, o direito ao acesso à saúde não significa que toda e qualquer assistência deveria ser provida pelos outros, mas sim que nenhuma pessoa deveria ser impedida de obtê-la (p. 278-9) ${ }^{17}$.

Apenas na $2^{a}$. edição, existia afirmação de que há tanto uma dimensão econômica quanto uma ética na alocação em políticas de saúde ("[...] say that there is both an economic dimension and an ethical dimension to problems of allocation and health policy" - p. 201) ${ }^{68}$.

Acresceram, na $2^{a}$. edição, afirmação e discussão sobre o fato de que todas as pessoas deveriam ter direito a igual acesso a assistência de saúde e direito a um mínimo decente na assistência de saúde ("[...] that there is a right to equal access to medical care [...], that there is a right to a decent minimum of medical care" - p. 203-4) ${ }^{68}$. Isso foi mantido na $3^{a}$. edição (p.278-9) ${ }^{17}$.

Desde a $1^{\text {a }}$. edição, afirmavam que os utilitaristas defendem que os provedores de saúde fazem (pois deveriam) as decisões de alocação baseadas no valor social das pessoas (p. 197 e 214-5) ${ }^{31}$. Na $2^{a}$., explicaram também o método da triagem como sendo o que destina cuidados médicos de acordo com as necessidades e prognósticos das pessoas, fazendo "o maior bem ao maior número" ("Some defenders of utilitarian selection, [...] invoke the model of triage, [...] sorted for medical attention according to their needs and prospects 
[...] 'Do the greatest good for the greatest number" - p. 214-5) ${ }^{68}$, parte preservada na $3^{\text {a }}$. edição (p. 300) ${ }^{17}$.

Da mesma forma, ao falarem sobre as decisões que não envolvem os valores sociais das pessoas, na $1^{\text {a }}$. edição, citavam apenas que se baseiam em urgência e necessidade médica dos tratamentos (p. 197) ${ }^{31}$, já, na $2^{a}$. edição, incluíram, como critério a ser observdo, o do prognóstico de sucesso do tratamento ("Such a classification in terms of urgency of medical need and prospect of successful treatment establishes priorities of treatment that do not involve judgments about social worth") ${ }^{68}$. Na $3^{\text {a }}$. edição, trocaram valor social ("social worth") por "valor social comparado" ("individuals' comparative social worth" - p. 300) ${ }^{17}$.

Continuando, somente na $2^{\mathrm{a}}$. edição, citavam Winslow, o qual defende o uso de princípios da teoria de Rawls que poderiam se utilizar do "véu da ignorância" nas decisões de microalocação em saúde, dando prioridade aos princípios igualitários (que se utilizam de fila ou sorteio) em detrimento dos utilitários ("[...] ethical analysis of microallocation decisions in health care, Gerald Winslow "filters" various principles through Rawls's theory of justice, asking which principles rational contractors would adopt behind the "veil of ignorance" [...] would reject or subordinate utilitarian principles to egalitarian principles and that those egalitarian principles would require queuing or random selection" - p. 214) ${ }^{68}$.

Ainda sobre o assunto, unicamente na $2^{\mathrm{a}}$. edição, afirmavam que é necessário determinar se os candidatos a um recurso escasso realmente tiveram justa oportunidade de entrar na fila ou de participar de loteria ("[...] it is necessary to determine whether the candidates for a scarce resource really had fair opportunity to enter the queue or the lottery" - p. 214) ${ }^{68}$.

Explicam, a partir da $2^{\mathrm{a}}$. edição, que uma tese comum a todas as abordagens de justiça é a de que os programas de distribuição e de assistência a determinados grupos de pessoas, como a pobres e a idosos, devem atender a todas as pessoas da mesma categoria de forma igual - sob pena de se 
promover novas injustiças ("One thesis common to virtually all accounts of justice is that delivery programs and services designed to assist persons of a certain class, such as the poor and the aged, should be made available to all members of that class. To deny access to some when others receive the benefits, seems clearly unjust" - p. 187) ${ }^{68}$. Comentário mantido na $3^{\mathrm{a}}$. edição $(259-260)^{17}$.

Exclusivamente na $2^{\mathrm{a}}$. edição, desenvolveram a ideia de "capacidade para pagar" ("ability to pay") como princípio de mercado da teoria libertária, por meio da citação de Nozick: "[...] melhor que se deixe aos cuidados do mercado os serviços de assistência à saúde, onde o princípio distributivo implícito é a capacidade para pagar [...]" ("[...] health care services and goods are best left to the marketplace, where the implicit distributive principle is ability to pay [...] This theory of justice has been developed in considerable detail in the work of Robert Nozick [...]" - p. 190) ${ }^{68}$.

Introduziram, na $2^{\mathrm{a}}$. edição, explicação de que o princípio da capacidade para pagar, de cunho libertário, se concentra nos direitos individuais das pessoas, onde cada um escolhe o quanto quer contribuir, recebendo, em contrapartida, seus ônus e bônus ("This marketplace principle relies upon some form of libertarian theory of justice for its justification [...] concentrate on the individual rights of persons [...] People choose to contribute to economic arrangements as they wish, and because contributions are freely chosen [...] discriminate among individuals in distributing economic burdens and benefits" p. 190$)^{68}$, sendo transposta para outros capítulos ao longo da $3^{\text {a }}$. edição, o sobre as teorias da justiça (p. 267) e o sobre a justa oportunidade (p. 277) ${ }^{17}$.

Na $1^{\text {a }}$. edição (p. 174-5) apenas, explicavam que a Teoria da Justiça de Rawls desafia as de cunho libertário ${ }^{31}$. Na $2^{\mathrm{a}}$., explicaram que ela prega que a distribuição deveria ser igual a todos, ao menos que a desigual pudesse gerar benefícios também a todos - à isso, chamavam de "concepção igualitária de Kant" ("John Rawls's theory of justice [...] presents a challenge [...] has its central contention that we should distribute all vital economic goods and services equally, unless an unequal distribution would actually work to 
everyone's advantage [...] what he calls the "Kantian conception of equality" - p. 190-1) $)^{68}$. Isso continuou, mas foi passado para outro capítulo, o das teorias da justiça, na $3^{\mathrm{a}}$. edição (p. 269) ${ }^{17}$.

$\mathrm{Na} 1^{\mathrm{a}}$. (p. $\left.174-5\right)^{31}$ e na $2^{\mathrm{a}}$. edição, explicavam que um dos mais intensos debates de justiça distributiva nos Estados Unidos foi sobre a seguridade de saúde nacional, nesta edição, disseram que, historicamente, sempre foi operada pelas leis de mercado, onde seu princípio implícito de acesso é a capacidade para pagar, baseada em teorias libertárias de justiça ("One of the more intense debates about distributive justice [...] the issue of national health insurance [...] are best left to the marketplace, where the implicit distributive principle is ability to pay. This marketplace principle relies upon some form of libertarian theory of justice for its justification" - p. $190 \mathrm{da})^{68}-\mathrm{o}$ que foi passado para outro capítulo, o das teorias da justiça, na $3^{a}$. edição ( $p$. $266)^{17}$.

Apenas nas duas primeiras edições (p. 175 e p. 191, respectivamente $)^{31,68}$, aclaravam que, apesar do sistema proposto por Rawls ser de cunho igualitário, ou seja, baseado na distribuição de recursos pela necessidade, serviços de saúde de luxo ainda poderiam ser comprados à parte; segundo $B \& C$, a diferença seria que, neste sistema, garantir-se-ia a todos o que Charles Fried chamava de "mínimo existencial" (conforme explicações já aqui tecidas sobre a tradução) (" [...] Rawls's theory for national health care are egalitarian [...] distribution would proceed on the basis of need [...] luxury hospital rooms and expensive but optional dental work, would be made available for purchase at personal expense [...] everyone's health needs would be met at the level Charles Fried has described as a "decent minimum" p. 191$)^{68}$.

Apenas na $2^{\mathrm{a}}$. edição, continuaram a tocar no tema da pesquisa clínica com seres humanos, debatendo sobre a possibilidade ou não de se compensar um sujeito de pesquisa por dano não oriundo de negligência quando voluntariamente consentiu em participar da pesquisa. Apesar de debaterem, B\&C, contudo, não dão as respostas ("[...] whether injured research subjects 
must be compensated for injury if they voluntarily consented to participate in the research and the injury was not the result of negligence" - p. 194-5) ${ }^{68}$.

Apenas na $2^{\mathrm{a}}$. edição, e ao contrário do que afirmavam na $1^{\mathrm{a}}$. (p. 196) ${ }^{31}$, os critérios objetivos de escolha de sujeitos de pesquisa, mesmo sendo objetivos, parecem mais subjetivamente calcados do que objetivamente, apesar de não se confundirem com critérios arbitrários, assim, eis que não arbitrários, podem sim ser reduzidos a critérios médicos ou utilitários, e não apenas ao papel social de cada sujeito ("[...] objective criteria could be fairly applied, it is not clear that they could be adequately justified [...] Such criteria often seem arbitrarily selected, and thus appear more subjectively grounded than objectively justified. If they are not merely arbitrary, they can be reduced to either medical criteria or utilitarian criteria" - p. 213-4) ${ }^{68}$.

Unicamente até a $2^{a}$. edição, tal qual na $1^{a}$. (p. 194) ${ }^{31}$, afirmavam que, se os recursos não fossem escassos, os médicos deveriam afastar das pesquisas apenas aquelas pessoas que não se beneficiariam dela ("If physicians and other health care professionals were to view scarcity as irrelevant to their determination of the initial pool, they would exclude only those candidates who could not possibly benefit from the treatment' - p. 212) ${ }^{68}$.

Apenas na $2^{a}$. edição, explicavam que questionamentos sobre justiça surgem até na escolha de sujeitos de pesquisa, pois nem os benefícios nem os ônus devem ser distribuídos injustamente ("[...] Questions about justice can be raised about selecting persons to participate in clinical research, as well as in nontherapeutic research. Neither the benefits nor the burdens of research should be unjustly distributed in society" - p. 211) ${ }^{68}$.

$\mathrm{Na} 1^{\mathrm{a}}$. edição (p. 182-3) ${ }^{31}$, já traziam a posição de uma associação e de um periódico científico sobre a possibilidade, ou não, de deficientes mentais participarem de pesquisas clínicas, o que foi matido apenas até a $2^{a}$. edição ${ }^{68}$. A associação defendia a posição de que nenhuma pesquisa clínica poderia ser feita com deficientes mentais, a não ser que estivesse diretamente relacionada com a etiologia, patogênese, prevenção, diagnóstico ou tratamento da doença 
propriamente dita - o que não autorizaria estudos como o de Willowbrook ("The American Bar Association has taken the position that no research can be done on the mentally disabled unless it relates immediately to the etiology, pathogenesis, prevention, diagnosis, or treatment of mental disability itself. This position would not permit studies such as Willowbrook [...]" - p. 196-7) ${ }^{68}$.

O periódico defendia que estas pesquisas seriam muito importantes à compreensão da hepatite, assim, potencialmente valiosas às crianças da instituição, não havendo prejuízos a elas porque provavelmente contrairiam hepatite de qualquer jeito, além disso, foram realizadas por competentes pesquisadores - defendendo o estudo de Willowbrook ("[...] former editor of The New England Journal of Medicine, have taken the position that such research is highly valuable for understanding hepatitis, was of potential value to the children in the institution, did not overburden children (because they probably would have contracted hepatitis anyway), and was carried out by exceptionally competent investigators" - p. 196-7 $)^{68}$. Na $3^{\mathrm{a}}$. edição, o caso de Willowbrook apenas é referido no apêndice da obra (p. 264) ${ }^{17}$.

Nas duas primeiras edições (p. 184 e p. 197-8, respectivamente), se referiam a pessoas com deficiência mental chamando-as de pessoas com "vagarosidade" ("slowness") ${ }^{31,68}$. Na $3^{\mathrm{a}}$., passaram a se referir a pessoas com "retardamento" (“retardation" - p. 271) ${ }^{17}$.

$\mathrm{Na} 1^{\text {a }}$. edição (p. 184) ${ }^{31}$, já defendiam a necessidade de educação especial para estas pessoas, contudo, apenas até a $2^{\mathrm{a}}$. edição, ao falarem sobre a diferença de custos, pois este tipo de serviço sairia mais caro, defendiam dever ser financiada pelo Estado dentro de recursos limitados ("Hence we introduce different levels of education for different kinds of students, regardless of the differential in cost (but within limits of resources)" - p. 271) ${ }^{68}$.

Na $1^{a}$. (p. 172) e na $2^{a}$. edição, explicam que qualquer teoria plausível de justiça deveria especificar as diferenças relevantes entre os indivíduos ${ }^{31,68}$. Segundo B\&C, um dos aspectos mais difíceis da justiça é justamente estabelecer como especificar os aspectos relevantes pelos quais as pessoas 
deveriam ser tratadas de forma igual, assim, os princípios materiais de justiça são aqueles que especificam estes aspectos relevantes das pessoas, conferindo conteúdo material à teoria da justiça ("Any plausible theory of justice must specify the relevant differences between individuals [...] Some of the most difficult questions about justice arise over how to specify the relevant respects by which people are to be treated equally. Principles that specify these relevant respects are said to be material principles, because they put material content into a theory of justice" - p. 187$)^{68}$. Na $3^{a}$. edição, mantiveram os argumentos (p. 260) $)^{17}$.

Apesar de citarem na $1^{\text {a }}$. edição (p. 174$)^{31}$, apenas na $2^{a}$., explicam o que seria uma "necessidade fundamental" ("fundamental need"), sendo aquilo que, caso a pessoa seja privada de obter, será ferida ou seriamente afetada da forma mais fundamental ("To say that someone has a fundamental need for something is to say that the person will be harmed or detrimentally affected in a fundamental way if that thing is not obtained" - p. 189) ${ }^{68}$.

$\mathrm{Na} 1^{\mathrm{a}}$. (p. 192$)^{31}$ e na $2^{\mathrm{a}}$. edição apenas, explicaram também em que consistiria o princípio da necessidade - o qual regula a justa distribuição baseada no que compreende por necessidade ('[...] the principle of need'. This principle declares that distribution is just (fair, deserved) when it is based on need" - p. 189) $)^{68}$. Além disso, somente na $2^{2}$. edição, recomendaram seu uso em conjunto com o princípio da justiça formal - o qual conhecemos melhor por equidade ("We can expand this basic idea about need by calling on the formal principle of justice" - p. 189$)^{68}$.

Sobre a importância do conceito de necessidade, explicam apenas na $1^{\mathrm{a}}$. (p. 174$)^{31}$ e na $2^{\mathrm{a}}$. edição, que quanto mais se refine este conceito mais próximo se estará das propriedades relevantes de uma política de atuação em saúde ("The more we refine the notion of need, the closer we move toward the relevant properties necessary for the formulation of a policy position [...] we would have to decide which needs are fundamental and which are not in order to develop a national health policy" - p. 189-90, ${ }^{68}$. 
Na mesma $2^{\text {a }}$. edição (p. 198-200) ${ }^{68}$, mantém as considerações sobre a regra da justa oportunidade ("fair opportunity rule"), inclusive sobre a teoria causal das origens das vantagens e desvantagens ("theory of the causal origins of advantageous and disadvantageous properties"), anteriormente feitas na $1^{\text {a }}$. edição (p. 184-6) $)^{31}$.

Porém, na $2^{\mathrm{a}}$. edição, passaram também a discutir o exemplo dos fumantes e dos alcoolistas, que poderiam ser responsáveis, ou não, pelas doenças resultantes de seus hábitos deletérios, o que, como consequência, poderia acarretar, ou não, direito à assistência de saúde pública ("If, for example, one believes that alcoholics are not responsible for their health problems, whereas smokers are, then one might argue that smokers should pay for their health care but that the state should pay for the care of alcoholics" - p. $198)^{68}$.

Mais adiante, na mesma $2^{\mathrm{a}}$. edição, incluíram citação de Rawls sobre a alocação de recursos de saúde sob o prisma da loteria natural social, a qual defende que seria moralmente neutra ("natural lottery is morally neutral" - p. $200-1)^{68}$. Sobre todos estes temas, na edição seguinte, questionam se as doenças resultantes de comportamentos deletérios deveriam ser cobertas pela assistência à saúde, trazendo mais um exemplo, o da AIDS (p. 280-1) ${ }^{17}$.

Por fim, na $2^{\mathrm{a}}$. edição, também afirmaram que algumas pessoas podem não entrar na fila a tempo, por questões de demora na procura por tratamento, inadequado ou incompetente cuidado médico, demora na marcação ou evidente discriminação ("[...] some people may not [...] enter the queue or the lottery because of such factors as slowness in seeking help, inadequate or incompetent medical attention, delay in referral, and overt discrimination" - p. $214)^{68}$.

$\mathrm{Na} \mathrm{3} 3^{\mathrm{a}}$. edição, quase nas mesmas palavras, afirmam o mesmo (p. 298$9)^{17}$, porém, apenas na $2^{a}$., afirmaram que seria necessário determinar se os candidatos para o tratamento escasso tiveram, ou não, a justa oportunidade de entrar na fila a tempo, parte retirada na $3^{a}$. edição ("[...] it is necessary to 
determine whether the candidates for a scarce resource really had fair opportunity to enter the queue or the lottery" - p. 298-9) ${ }^{68}$.

$\mathrm{Na} 1^{\mathrm{a}}$. edição, relatavam apenas que alguns critérios psicológicos podem ser também medicamente relevantes $(p .194)^{31}$. Já, na $2^{a}$., passaram a afirmar que alguns critérios medicamente relevantes poderiam ser também socialmente, como o alcoolismo, a instabilidade no emprego, o comportamento anti-social ou as doenças psiquiátricas ("[...] criteria at some institutions appeared to be 'social' as well as 'medical'. Stanford's criteria excluded patients with "a history of alcoholism, job instability, antisocial behavior, or psychiatric illness", while requiring "a stable, rewarding family and/or vocational environment to return to post-transplant" - p. 211-2) $)^{68}$. Na $3^{a}$. edição, mantiveram tais considerações (p. 294 $)^{17}$.

Apenas na $2^{a}$. edição, havia relato de que, apesar de as pessoas em geral considerarem fumantes, alcoolistas e obesos como pessoas nãoautônomas nos seus estilos de vida, este argumento é difícil de ser sustentado. Também que, se um comportamento deletério for involuntário, a sociedade deve proibir ou regular isso, como forma de proteção do indivíduo ("[...] those whose health is affected by smoking, alcohol abuse, or obesity are engaging in what may be for them substantially nonautonomous behavior, even though they knowingly engage in the behavior and might oppose policies that penalize them for such behavior [...] Such an argument is difficult to sustain [...] if an individual's behavior is substantially nonvoluntary, the society may prohibit or regulate it in order to protect the individual" - p. 207) ${ }^{68}$. Segundo B\&C, a beneficência suporta isso e a autonomia e a justiça não proíbem ("Beneficence supports such a policy, and neither autonomy nor justice precludes it' - p. $207)^{68}$.

Adicionaram, na $2^{a}$. edição, esclarecimento de que seria difícil, se não impossível, apontar as responsabilidades por cada necessidade médica, por causa da loteria natural, das práticas sociais e das escolhas individuais (" $[\ldots]$ it is difficult if not impossible to pinpoint responsibility for most health needs 
because of the complex interactions of the "natural lottery", societal practices, and individual choices" - p. 208-9) ${ }^{68}$.

Na $3^{a}$. (p. 282), acrescentaram, como razões para se considerar quase impossível apontar as responsabilidades por cada uma das necessidades médicas, fatores causais, a complexidade das doenças, limitações do conhecimento, predisposições genéticas, ações pessoais e condições sociais e de meio ambiente, além dos motivos de que muitos riscos de doença não serem conhecidos ainda por todos ou mesmo pelas pessoas em geral ${ }^{17}$.

Na $2^{\text {a }}$. edição, tal qual na $1^{\text {a }}$. (p. 178-9 $)^{31}$, argumentam que, mesmo que fosse possível estabelecer quais hábitos deletérios adotados pela pessoa resultaram na sua doença, para se saber se ela possui direito à assistência de saúde ou não, isso poderia causar um comprometimento do princípio do respeito pela autonomia e de sua regra de privacidade ("Second, since such a policy would require "health police" to investigate personal lifestyles and behavioral patterns, it would invite violations of moral principles and rules relating to autonomy and privacy" - p. 208-9) ${ }^{68}$. Na $3^{\mathrm{a}}$., repetem os argumentos incluindo também a regra da confidencialidade (p. 282 ${ }^{17}$.

$\mathrm{Na} 2^{\mathrm{a}}$. edição apenas, existiu defesa de que qualquer política baseada nas individualidades negaria o contexto social das ações individuais, o que tenderia a culpar as vítimas, em detrimento de se culpar a sociedade ("[...] any policy focusing on individual lifestyles and behavioral patterns may be criticized on the grounds that it tends to neglect the social context of individual actions. It tends to 'blame victims', rather than to 'blame society' - p. 209) ${ }^{68}$.

Tão somente na $2^{\mathrm{a}}$. edição, afirmavam que a sociedade deve também prevenir ou limitar também ações deletérias voluntárias, a fim de evitar riscos ou custos que recaiam sobre outros ("Even if an individual's risk-taking is substantially voluntary, society may limit it in order to prevent the imposition of risks or costs on others" - p. 207) ${ }^{68}$. 
$\mathrm{Na} 2^{\mathrm{a}}$. edição, incluíram que não seria paternalista proteger os recursos financeiros da sociedade, como, por exemplo, tributando as pessoas que assumem estilos de vida arriscados (como os alcoolistas e os fumantes), assim, cobrindo os seus maiores gastos em saúde ("Another relevant nonpaternalistic consideration is protection of the financial resources of the community [...] One possible policy would be to tax risk-takers more heavily (for example, through increased taxes on alcohol and cigarettes) in order to cover their increased health costs" - p. 208) ${ }^{68}$. Na $3^{\mathrm{a}}$., complementam que as pessoas de grupos de risco deveriam contribuir mais com seguros específicos ou pagar tributos por suas condutas de risco, como uma elevação dos tributos de cigarros. Isso redistribuiria os custos de saúde de maneira justa e não desrespeita o princípio da autonomia destas pessoas (p. 283 $)^{17}$.

Ao contrário disso, apenas na $2^{\mathrm{a}}$. edição, asseguravam que estilos de vida arriscados podem, na realidade, requerer menores cuidados de saúde. Uma análise ampla de custo-benefício poderia desprestigiar as políticas de saúde interventivas nestes grupos de risco. Citam Leichter, que defende que pode se esperar um aumento, ao invés de uma diminuição, nos custos de saúde como resultado de se evitar riscos em saúde ("[...] some risky lifestyles and conduct may actually require less medical care. Furthermore, under a broad cost-benefit analysis (including social security and retirement programs), there may be even less reason for government intervention in some riskytaking. As Howard Leichter argues, [...] one can expect an increase rather than decrease in social expenditures as a result of avoiding health risks" - p. 208) ${ }^{68}$.

$\mathrm{Na} 3^{\mathrm{a}}$. edição, porém, excluíram esta passagem, afirmando que talvez as pessoas pertencentes a grupos de risco requeiram menos recursos médicos porque tendem a morrer mais cedo e mais rápido do que aqueles que vivem mais e desenvolvem doenças crônicas (p. 282-3), além disso, que a maior razão para se discutir direitos na assistência à saúde é o crescente aumento dos seus custos (p. 282-3) ${ }^{17}$.

$\mathrm{Na} 2^{\mathrm{a}}$. edição, incluíram citação de Veatch, que afirma que seria justo tratar de forma melhor as pessoas que ficaram doentes involuntariamente, 
chegando a defender que seria injusto tratá-las igual (Robert Veatch has argued that 'it is fair [...] if persons in need of health services resulting from true, voluntary risks are treated differently from those in need of the same services for other reasons. In fact, it would be unfair if the two groups were treated equally' - p. 208) ${ }^{68}$. Na $3^{a}$. edição, fazem a mesma menção (p. 281 $)^{17}$.

Iniciaram, na $2^{\mathrm{a}}$. edição, a discussão sobre como o incremento da qualidade de vida dos indivíduos e da prevenção podem ser mais eficientes na promoção de saúde do que a medicina exclusivamente curativa ("[...] health care, particularly medical care, may not be the most effective and efficient way to protect and promote health" - p. 204) ${ }^{68}$. Chegaram a afirmar que alocar recursos na assistência à saúde ou na tecnologia em detrimento de se melhorar a qualidade de vida das pessoas seria o mesmo que "desalocar" ("misallocate") os recursos ("[...] many improvements in health care can be traced to improvements in the standard of living rather than to improvements in medical care or technology. Some even argue that to concentrate resources on medical care is to misallocate them" - p. 204 $)^{68}$. Na $3^{a}$. edição, ainda citam estudos que comprovam que, estatisticamente, outras condições como a qualidade de vida são mais importantes do que o próprio implemento da saúde (p. 284) $)^{17}$.

Incluíram, na $2^{\mathrm{a}}$. edição, discussão sobre o fato de que as sociedades em geral preferirem que os gastos em saúde se concentrem na medicina curativa, porque se destinam a pessoas identificáveis, apesar de na prevenção serem mais efetivos e eficientes ("Society is more likely to favor "identified persons" and to allocate resources for critical care, even if prevention would be more effective and efficient' - p. 204-5) ${ }^{68}$ - o que foi mantido na $3^{a}$. edição ( $p$. $288)^{17}$.

Apenas na $2^{a}$. edição, havia explicação sobre a prevenção, que consiste em fortalecer os indivíduos, modificar seus estilos de vida, seus modelos comportamentais e seus meios de inserção ("Prevention, [...] includes strengthening individuals [...], changing lifestyles and behavioral patterns, and altering the environment" - p. 207) ${ }^{68}$. 
Somente na $2^{\mathrm{a}}$. edição, também afirmavam que programas eficientes $\mathrm{e}$ eficazes embasados nos estilos de vida e modelos comportamentais logo esbarram nos limites do princípio da autonomia ("Effective and efficient preventive programs, especially those concentrating on lifestyles and behavioral patterns, soon encounter the limits set by the principle of autonomy" - p. 207) ${ }^{68}$.

Relataram, somente na $1^{a}$. (p. 206) ${ }^{31}$ e na $2^{a}$. edição, a dificuldade em se obter órgãos para transplantes (em especial, o consentimento de retirada), afirmando que as pessoas deveriam ser obrigadas a se manifestar e, para as que não quisessem assim proceder, que se subentendesse que a resposta era positiva ("[...] to force people to make a decision [...] routine salvaging of organs unless people have explicitly denied permission" - p. 206) ${ }^{68}$.

Assim, na $3^{a}$. edição ${ }^{17}$, excluíram fala que havia na $1^{\mathrm{a}}$. (p. 195$)^{31}$ e na $2^{\mathrm{a}}$. edição, de que a sociedade deveria proteger também a relação médicopaciente da noção de investimento-retorno econômico, relação na qual o médico tem a tarefa de cuidar do paciente, da sociedade e ainda alcançar outros objetivos sociais ("[...] society may have a stake in protecting both the patient-physician relationship and the delivery of medical care from economic considerations of investment and return [...] Were the physician to look through the patient to the society and attempt to realize society's larger goals [...]" - p. $213)^{68}$.

Da mesma forma, aconteceu com o trecho em que ressaltavam que 0 médico não é o responsável por políticas públicas, tendo como primeira obrigação o paciente ("The physician is not a policymaker. His or her primary responsibility is to the patient' - p. 213 ${ }^{68}$.

A $2^{\mathrm{a}}$. edição foi a primeira a incluir uma conclusão ao final dos capítulos sobre os princípios. Nela, explicaram que não se deve utilizar apenas uma teoria da justiça, mas várias, já que cada uma delas foi construída sob diferentes concepções, sendo assim, cada uma absorveu apenas parte das diversidades que a vida envolve ("It is not entirely clear that we must accept a 
single theory of justice in order to reflect constructively on these problems, for it is possible to conceive each general theory of justice as developed from a different conception of the moral life, a conception that only partially captures the diversity of that life" - p. 216) ${ }^{68}$.

Nesta conclusão, explicavam também que tais teorias parecem opostas, mas que, apesar disso, nenhuma sociedade consegue seguir unicamente uma delas. Isso porque nenhuma das teorias consegue traduzir tanta diversidade com unicidade ("One widely view is that these theories are irreconcilably opposed [...] we have no available theory at the present time to bring such diverse accounts into unity" - p. 216) ${ }^{68}$. Tudo matido na $3^{a}$. edição (p. 301).

Assim, B\&C esclarecem que não se deve ficar surpreso se teorias conflitantes emergirem, certo é que, hoje, existem várias teorias de justiça plausíveis e igualmente viáveis ("[...] we should not be surprised of competing theories emerge [...] at the present time there are several plausible, and perhaps equally viable, theories of justice" - p. 217$)^{68}$ - parte também conservada na $3^{a}$. edição (p. 301).

\section{Alterações da $3^{a}$. frente à $2^{a}$. e à $4^{a}$. edição}

$\mathrm{Na} 3^{\mathrm{a}}$. edição, as mudanças foram mais substanciais. Os tópicos "The Concept of Justice" (O Conceito de Justiça) e "Fair Opportunity" foram os únicos a permanecerem intactos. O tópico "Material Principles of Justice" (Princípios Materiais de Justiça) foi reduzido a "Principles of Justice" (Princípios de Justiça). Novos, como "Theories of Justice" (Teorias de Justiça), "The Right to a Decent Minimum of Health Care" (O Direito a um Mínimo Decente em Saúde), "Priorities in the Allocation of Health-Care Resources" (Prioridades na Alocação de Recursos em Saúde) e "Rationing Health Care" (Racionando em Saúde), foram incluídos. Os tópicos "Relevant Properties" (Propriedades Relevantes), "Macroallocation and Health Policy" (Macroalocação e Política de Saúde)" e "Microallocation" (Microalocação) foram excluídos. Além disso, uma 
conclusão ("Conclusion") ao final de cada capítulo sobre princípios foi adicionada na obra ${ }^{17}$.

$\mathrm{Na} 2^{\mathrm{a}}$. edição, incluíram um resumo do foco de cada uma das teorias da justiça em apenas um parágrafo (p. 188-9) ${ }^{68}$. Na $3^{\mathrm{a}}$., há todo um capítulo sobre o assunto (p. 265-270), já, na introdução, explicando que as teorias da justiça sistematizam, simplificam e organizam as diversas regras e julgamentos ("[...] theories of justice are devoted to systemizing, simplifying, and ordering our diverse rules and judgments" - p. 265) ${ }^{17}$. Na $4^{\mathrm{a}}$., passaram a explanar que as teorias da justiça foram desenvolvidas para especificar e manter coerente os princípios, as regras e os julgamentos morais. Uma teoria, por sua vez, tenta conectar as características de pessoas por meio de distribuições de benefícios e obrigações moralmente justificáveis (p. 334 $)^{16}$.

$\mathrm{Na} 3^{a}$. edição, adicionaram afirmação de que uma única teoria da justiça que cobrisse todas as diversas perspectivas possíveis seria impossível, apesar de muitos princípios da justiça não serem diferentes e nem independentes dos da autonomia, da não-maleficência e da beneficência ("It has proved an intractable problem to supply a single, unified theory of justice that brings together our diverse views. Indeed, many principles of justice do not seem distinct from and independent of the principles of respect for autonomy, nonmaleficence, and beneficence" - p. 256) $)^{17}$. Isso foi conservado na $4^{\mathrm{a}}$. edição (p.326-7) ${ }^{16}$.

Apenas na $3^{a}$. edição, declararam que o que torna uma teoria correta é o fato de ter sido a escolhida livremente pelos membros de um grupo ("What makes them right is precisely the free choice of the members of the group" - $p$. $267)^{17}$.

Tão somente na $3^{a}$. edição, aclaravam que existe um equívoco comum em relação à justiça. Na literatura ética biomédica, "justo" ("what is just") costuma ser utilizado em sentido amplo e equivocado para se referir ao que é justificável ou moralmente correto. Assim, muitos dos conflitos tratados pela 
justiça constituem, na verdade, conflitos relacionados à autonomia, beneficência ou não-maleficência ("Throughout this analysis we need to avoid a common confusion of justice with. Appeals to 'what is just' in the literature of biomedical ethics often the term just in a broad and equivocal sense to refer to what is generally justified or morally right [...] many complaints of justice are more properly categorized as alleged violations of some principle other than justice" - p. 256-7) $)^{17}$.

$\mathrm{Na} 2^{\mathrm{a}}$. edição, asseguravam que regras de justiça distributiva, como mérito, sacrifício e contribuição são inapropriadas onde regras de justa oportunidade devem ser aplicadas, como no caso das pessoas que não fizeram nada para ficarem doentes e também merecem tratamento (p. 198-9) ${ }^{68}$. Na edição seguinte, apesar de terem retirado esta passagem, trouxeram 0 exemplo de que, se as pessoas não são responsáveis por seu processo de envelhecimento, seria injusto alocar assistência prioritária a jovens antes de idosos ("If people are not responsible for conditions introduced by the aging process, it would seem unjust to allocate so as to provide care for a younger person before an older person" - p. 272) ${ }^{17}$. Isso foi retirado na $4^{a}$. edição, que passou a apontar Daniels, o qual defende que decisões prudentes deveriam fazer uso do critério da idade de forma a levar em consideração não apenas um momento na vida, mas toda a sua duração, alocando-se os recursos de forma prudente através de todos os seus estágios de maneira a aumentar as chances de se obter uma normal duração da vida (p. 370 $)^{16}$.

Unicamente na $3^{a}$. edição, escreveram que alguns filósofos defendem que o princípio da justiça deveria predominar nos conflitos entre princípios. B\&C rebatem com seu argumento de que os princípios são prima facie, nem sempre triunfando apenas a justiça. Por conseguinte, uma posição justa pode ser injustificável e uma posição injusta pode ser justificável, a depender do contexto ("Some philosophers have also maintained that [...] the principles come into conflict, justice must always be the overriding principle. By contrast, our argument about prima facie principles supports the conclusion that principles of justice do not always triumph over other principles. Hence a policy 
may be just but unjustified, or unjust but justified, when justice conflicts with other principles" - p. 257) ${ }^{17}$.

$\mathrm{Na} 3^{a}$. edição, tal qual fizeram na $2^{a}$. (p. 187$)^{68}$, ilustram o que são os princípios materiais de justiça, quais sejam, aqueles que especificam os aspectos relevantes das pessoas, conferindo conteúdo material à teoria da justiça ao identificar as propriedades relevantes à distribuição ("Principles that specify these relevant characteristics are said to be material principles because they alone put material content into a theory of justice by identifying relevant properties for distribution" - p. 260-1) ${ }^{17}$. Tudo isso foi removido na $4^{a}$. edição ${ }^{16}$. Mesmo assim, a partir da $3^{a}$. edição, passaram a colocar um exemplo de princípio material de justiça válido: o de "livres trocas de mercado" ("To each person according to free-market exchanges" - p. 261$)^{17}$, que foi mantido na $4^{a}$. edição (p. 330 $)^{16}$.

$\mathrm{Na} 2^{\mathrm{a}}$. edição apenas, traziam toda uma discussão sobre os programas de distribuição e de assistência a determinados grupos de pessoas, como a pobres e a idosos, (p. 187); sobre a "capacidade para pagar" ("ability to pay") como princípio de mercado de teoria libertária de justiça (p. 190); sobre a Teoria da Justiça de Rawls, que desafia as de cunho libertário (p. 190-1); e sobre o "mínimo existencial" (assim aqui traduzido, como já explicado - p. $191)^{68}$.

Porém, na $3^{a}$. edição, passaram a falar da dificuldade de se promover acesso igual à saúde e, ao mesmo tempo, promover a melhor assistência possível a todos e, ainda, manter um ambiente de livre mercado competitivo na área ("[...] to provide the best possible health care for all citizens based on their needs, while simultaneously promoting the public interest through costcontainment programs [...] the ideal of equal access to health care for everyone, including care for indigents, while maintaining a free-market competitive environment in health care" - p. 265) ${ }^{17}$ - o que foi mantido na $4^{a}$. edição ( $p$. $335)^{16}$. 
Ainda na $2^{\mathrm{a}}$. edição, já explicavam que o princípio da capacidade para pagar, de cunho libertário, se concentra nos direitos individuais das pessoas, onde cada um escolhe o quanto quer contribuir e, por causa e de acordo com isso, recebem seus ônus e bônus correspondentes (p. 190) ${ }^{68}$.

$\mathrm{Na} 3^{\mathrm{a}}$. edição, primeiramente, complementam esta passagem, afirmando que esta era a posição de autores libertários como Locke e Smith (“[...] contemporary libertarian writers, as well as classical exponents such as John Locke and Adam Smith, assume an individualist conception of economic production and value [...]" - p. 267) ${ }^{17}$.

Depois, também certificaram apenas na $3^{a}$. edição que, porque a regra da justa distribuição prevê que cada um tem direito a recursos de saúde na medida em que contribuiu, uma outra questão moral reside no fato de que as pessoas muito doentes ou machucadas exigiriam maiores gastos e, em complemento, provavelmente também estejam em piores condições de trabalhar e de contribuir ("All citizens have a right to the resources correlative to this societal obligation. Moreover, the need for health care is far greater among the seriously diseased and injured [...]" - p. 277) ${ }^{17}$.

Por fim, passaram a explicar, unicamente na $3^{a}$. edição, que a justiça comparativa demanda justa distribuição, e não uma extremamente ampla distribuição ("Comparative justice demands a fair share, not an extremely large share" - p. 272) ${ }^{17}$. Mesmo retirando estas passagens, na $4^{\mathrm{a}}$. edição, realizaram acréscimos, como o de que a assistência à saúde, na concepção do princípio da capacidade para pagar, não representa um direito e que a privatização do sistema de saúde é um valor protegido porque, nestas sociedades de justiça libertária, existem direitos de propriedade e de liberdade (p. 336) ${ }^{16}$.

$\mathrm{Na} 2^{\mathrm{a}}$. edição, já explicavam que um dos mais intensos debates de justiça distributiva nos Estados Unidos foi sobre a seguridade de saúde nacional, historicamente operada pelas leis de mercado, onde o princípio implícito de acesso era a capacidade para pagar (p. 190) ${ }^{68}$. 
$\mathrm{Na} 3^{\mathrm{a}}$. edição, complementaram afirmando que procedimentos de saúde em um mercado realmente livre não deveriam ser uma questão de planejamento social, mas exclusivamente de escolha individual; assim como, que a intervenção social no livre mercado, como consequência, discorda da justiça tornando problemas não cobertos escolhas individuais ("Events in a true free market should not be a matter of social planning but exclusively of individual choosing, and social intervention in the market therefore undetermines justice by placing unwarranted constraints on individual liberty" p. 266) $)^{17}$, o que foi mantido na $4^{\text {a }}$. edição (p. 336) ${ }^{16}$.

Porém, apenas nesta $3^{a}$. edição, afirmavam que, por esta teoria, até mesmo órgãos e bebês poderiam ser trocados por dinheiro no livre mercado ("Even organs and babies, according to this theory, can be transferred for money by individuals in the free market" - p. 266-7) ${ }^{17}$.

Apenas na $3^{a}$. edição, citaram Nozick quando do Estado mínimo, ou "Estado vigilante noturno" ("night-watchman state"), onde as ações governamentais seriam justificadas apenas se protegessem os direitos e as garantias dos cidadãos, propondo uma teoria de justiça que afirmasse direitos não de maneira coercitiva, mas de forma a criar modelos de distribuição econômica como os encontrados no socialismo e no capitalismo impuro, redistribuindo as riquezas por meio do livre mercado - como, por exemplo, na tributação progressiva dos mais afortunados ("Nozick promotes the minimal or "night-watchman" state, according to which government action is justified only if it protects the rights or entitlements of citizens [...] a theory of justice should affirm our rights not to be coerced rather than to create "patterns" of economic distribution such as those found in socialist and (impure) capitalist countries in which governments act to redistribute the wealth acquired by individuals in the free market [...] taxed at a progressively higher rate than those who are less wealthy [...]" - p. 268) $)^{17}$.

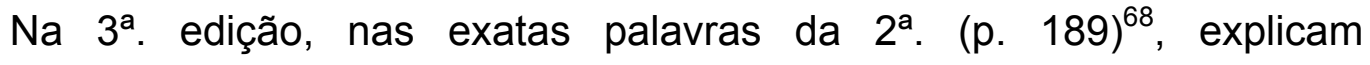
novemente o que seria uma "necessidade fundamental" ("fundamental need " p. 261$)^{17}$. Porém, neste exemplar, vão além, defendendo que o princípio da 
necessidade deveria ser considerado um princípio de justiça material válido ("[...] emphasizing the significance of the first step in the argument, the acceptance of the principle of need as a valid material principle of justice" - $p$. $261)^{17}$ - isso foi conservado na $4^{\text {a }}$. edição (p. 329-30 $)^{16}$.

A partir da $3^{a}$. edição, apresentaram o que seriam as "necessidades de assistência à saúde" ("Health-care needs"), ou seja, necessidades que englobam todo o necessário na assistência à saúde para atingir, restaurar ou manter as espécies em típico funcionamento ("Health-care needs are determined by whatever is necessary to achieve, restore, or maintain adequate ("species-typical") levels of functioning or functional equivalents of these levels" - p. 269-270) ${ }^{17}$.

Como consequência, à cada membro da sociedade, independentemente de riqueza ou posição social, seria provido acesso igual a um adequado (mas não máximo) nível de acesso à saúde ("Each member of society, irrespective of wealth or position, would be provided with equal access to an adequate (although not maximal) level of health care [..." - p. 270) ${ }^{17}$. Todas as passagens foram mantidas na $4^{a}$. edição (p. 340-1 $)^{16}$.

Até a $2^{\mathrm{a}}$. edição, se referiam a pessoas com deficiência mental chamando-as de pessoas com "vagarosidade" ("slowness" - p. 197-8) ${ }^{68}$. Na $3^{\mathrm{a}}$., passaram a usar a palavra "retardamento" ("retardation" - p. 271) ${ }^{17}$ e, na $4^{\mathrm{a}}$., alteraram para pessoas "com dificuldade de leitura ou deficiência mental" ("[...] with reading difficulties or mental deficiencies [...]" - p. 342) ${ }^{16}$.

$\mathrm{Na} \mathrm{2}{ }^{\mathrm{a}}$. (p. 197-8) ${ }^{68}$ e na $3^{\mathrm{a}}$. edição, defendiam a necessidade de educação especial para pessoas com deficiência mental. Contudo, na $3^{a}$. edição, retiraram a parte que falava sobre a diferença de custos, pois este tipo de serviço sairia mais caro, devendo ser financiado pelo Estado e sempre dentro de recursos limitados ("Hence we introduce different levels of education for different kinds of students, regardless of the differential in cost (but within limits of resources)" - p. 271) ${ }^{17}$. Na $4^{\mathrm{a}}$., continuaram (p. 342) ${ }^{16}$. 
Unicamente na $3^{a}$. edição, existia comentário sobre a teoria igualitária, mas na sua forma que chamam de "qualificada" ("qualified egalitarianism"), que requer a análise de apenas algumas igualdades entre os indivíduos, permitindo iniquidades, desde que devolvendo benefícios aos menos avantajados ("[...] qualified egalitarianism requires only some basic equalities among individuals, and permits inequalities that rebound to the benefit the least advantaged" - p. $268-9)^{17}$.

Isso porque, somente na $3^{a}$. edição, na esteira de Rawls, defendiam que uma justa sociedade deveria procurar nulificar as vantagens distribuídas arbitrariamente, por acidente biológico ou histórico (“[...] just society would seek to nullify the advantages stemming from the accidents of biology and history. As Rawls puts it, these fortuitous advantaging properties seem arbitrary [...]" - p. 269) ${ }^{17}$.

$\mathrm{Na} 2^{\mathrm{a}}$. edição, explicavam que a Teoria da Justiça de Rawls desafia as de cunho libertário, pois prega que a distribuição deveria ser igual a todos, ao menos que a desigual pudesse gerar benefícios também a todos (p. 190-1) ${ }^{68}$. Isso foi transposto a outro capítulo, o das teorias da justiça, na $3^{a}$. edição, onde acrescentam que Rawls se utiliza de um ahistórico e hipotético modelo de contrato social em que princípios válidos de justiça são aqueles que todos concordariam se pudessem livremente considerar uma posição social inicial que ele chama de "posição original" - "original position" ("He uses an ahistorical, hypothetical social contract model in which valid principles of justice are those to which we would all agree if we could freely consider the social situation from a standpoint that he calls the 'original position" - p. 269) ${ }^{16}$.

Em continuidade ao supra, na $4^{\mathrm{a}}$. edição, afirmaram que a Teoria da Justiça desafia as libertárias, incluindo que são um desafio às utilitárias também e explicando que Rawls entende justiça como o que seria razoavelmente justo ("fairness"), ou seja, como normas de cooperação acordadas por pessoas livres e iguais que participam das atividades sociais com respeito mútuo - o que, segundo B\&C, é consistente com a perspectiva de Rawls do equilíbrio reflexivo e da coerência ("[...] John Rawls's theory of justice 
presents an egalitarian challenge to libertarian and utilitarian theories. Rawls explicates justice as fairness, understood as norms of cooperation agreed to by free and equal persons who participate in social activities with mutual respect. Consistent with his views about reflective equilibrium and coherence" - p. 339$40)^{16}$.

Exclusivamente na $3^{a}$. edição, criticavam a ambivalência das teorias libertárias, que podem, ao mesmo tempo, defender que não querem a intervenção estatal sobre o que é seu e que se deve proporcionar assistência à saúde aos indigentes ("Libertarians can insist on our right to retain our property free of social compulsion and at the same time assert that morally we should be generous and provide health-care services for the indigent' - p. 278) ${ }^{17}$.

Da mesma forma, apenas na $3^{a}$. edição, B\&C explicavam que Engelhardt defende tanto que não existe direito a um mínimo existencial em saúde quanto que sua análise do princípio da beneficência e da autonomia suportam o "two-tired system" ("This is why Engelhardt can consistently say both that "a basic human right to the delivery of health care, even to the delivery of a decent minimum of health care, does not exist" and that his "analyses of the principles of beneficence and autonomy support a two-tiered system of health care" - p. 278) ${ }^{17}$ - um sistema de assistência à saúde de "duplo amarramento", onde duas vertentes estariam presentes, uma com um mínimo nível de bens socialmente alocados, e outra, com um segundo nível de bens conquistados por iniciativa individual (p. 269) ${ }^{17}$.

Apenas na $3^{a}$. edição, citando Rawls, $B \& C$ explicam que, por trás do véu da ignorância, agentes racionais deveriam escolher princípios da justiça que maximizassem o nível mínimo de bens primários com vistas a proteger interesses vitais e a evitar potenciais contextos danosos ou mesmo desastrosos. Alocações sociais que protejam o futuro da saúde de todos e que vão ao encontro das necessidades de saúde seriam optados por estes agentes - segundo B\&C, assumindo-se expressamente que a saúde é um bem primário ("Rational agents behind the "veil of ignorance" would choose principles of justice that maximize the minimum level of primary goods in order to protect 
vital interests in potentially damaging or disastrous contexts. Social allocations to protect everyone's future health and to meet health needs would thus be elected by such agents (assuming that health is a primary good)" - p. 269) ${ }^{17}$. Isso foi mantido na $4^{\text {a }}$. edição (p. 340$)^{16}$.

B\&C ainda explicam, apenas na $3^{\text {a }}$. edição, que esta abordagem suplementa o convencional sistema de distribuição de assistência à saúde que chama de "duplo amarramento" - esclarecido anteriormente ("This approach supplements the conventional marketplace system of distribution through a twotiered conception of a minimal level of socially allocated goods and a second level of goods gained by individual initiative" - p. 269) ${ }^{17}$.

Assim, B\&C, em outras palavras, definem o "duplo amarramento" como um sistema de saúde onde há um serviço público básico ("laço", "tier" 1) e outro paralelo privado para quem deseja um atendimento mais personalizado ("laço", "tier" 2) ("[...] two-tiered system of health care [...] social coverage for basic and catastrophic health needs (tier 1), together with private coverage for other health needs and desires (tier 2)" - p. 279) ${ }^{17}$.

Também, tão somente na $3^{\mathrm{a}}$. edição, citavam Engelhardt, que dizia que não existe direito humano básico à distribuição de saúde, nem mesmo a um mínimo existencial, além disso, que os princípios da beneficência e da autonomia embasam o sistema do "duplo amarramento" ("This is why Engelhardt can consistently say both that 'a basic human right to the delivery of health care, even to the delivery of a decent minimum of health care, does not exist" and that his "analyses of the principles of beneficence and autonomy support a two-tiered system of health care" - p. 278) ${ }^{17}$.

Da mesma forma, apenas na $3^{a}$. edição, B\&C diziam que concordam plenamente com Engelhardt (e outros libertários) que os princípios da beneficência e da autonomia dão suporte ao sistema do "duplo amarramento" ("[...] we fully agree with Engelhardt (and perhaps other libertarians) that the principles of beneficence and autonomy give support to a two-tiered system of health care" - p. 278) ${ }^{17}$. 
Nota-se que qualquer menção ao sistema do "duplo amarramento" foi excluída na $4^{a}$. edição, portanto, unicamente na $3^{a}$. edição, havia explicação de outro sistema semelhante, o do "único amarramento" ("one-tiered"), o qual garante níveis de saúde, tanto quanto possível, igual ao que as outras pessoas em geral possuem - rejeitado pela Teoria do Mínimo Existencial ("[...] onetiered, equal-access-for-all health-delivery system [...] 'to provide an opportunity for a level of health equal as far as possible to the health of other people' [...] approach rejected by the decent-minimum theory" - p. 279) ${ }^{17}$.

Isso porque, segundo $B \& C$, somente na $3^{a}$. edição, defendiam que deveria se criar um direito em saúde a itens de primeira necessidade, sem garantir tratamentos caros e raros. Ademais, sistemas assim serão meramente programáticos, a menos que alguém seja capaz de concretamente definir o que seria um mínimo existencial ("[...] right to care for primary needs without creating a right to exotic and expensive forms of treatment, such as liver transplants. More importantly, the model is purely programmatic unless one is able to define what 'decent minimum' means in concrete [... .' - p. 279-80) ${ }^{17}$.

$\mathrm{Na} 3^{\mathrm{a}}$. edição, acresceram uma lista de características desvantajosas, como voz esganiçada, rosto feio, pobre domínio do vernáculo ou inadequada educação primária - questionando até que ponto esta lista deveria ser extendida ("Numerous properties might be disadvantaging - for example, a squeaky voice, an ugly face, a poor command of a language, or an inadequate early education. How far in life should we extend the range of undeserved properties that create a right in justice to some form of assistance in overcoming the handicap?" - p. 272-3 $)^{17}$, explicando também que Rawls relaciona a distribuição de (des)vantagens ao que chama de "loteria natural" - "the natural lottery" - e de "loteria social" - "social lottery" ("One hypothesis is that virtually all 'abilities' and 'disabilities' are a function of what John Rawls refers to as 'the natural lottery' and 'the social lottery'"- p. 273) ${ }^{17}$. Partes mantidas na $4^{\mathrm{a}}$. (p. $343-4)^{16}$. 
Mais uma exclusividade da $3^{a}$. edição foi a afirmação de que o direito à assistência de saúde tem sido ilustrado mais por discurso político do que uma análise crítica ("The right to health care is a subject whose history has been characterized more by political rhetoric than by careful analysis" - p. 275) ${ }^{17}$.

Apenas nesta $3^{a}$. edição, explicaram também que Rawls defende que direitos assegurados pela justiça não podem ser objeto de barganha política ou de cálculo de interesses sociais ("[...] John Rawls has maintained that "the rights secured by justice are not subject to political bargaining or to the calculus of social interests" - p. 280) $)^{17}$.

$\mathrm{Na} 2^{a}$. edição, já havia afirmação de que escolhas trágicas na microalocação podem levar a sociedade, por meio dos governos, a alterar suas políticas de macroalocação, com vista a suprir os recursos escassos (p. 209$10)^{68}$. Na $3^{a}$. edição, porém, citam Daniels, que define nível macro como sendo o que abrange o alcance e a forma das instituições básicas de saúde, as instituições centrais e as práticas sociais que formam um verdadeiro sistema de saúde. Assim, as decisões em nível macro determinam: que tipos de assistência à saúde existirão em uma sociedade, quem irá recebê-los e em que condições, quem irá distribuir eles, como os ônus do financiamento serão distribuídos, e como o poder e o controle destes serviços serão distribuídos ("As Norman Daniels put it, 'the macro level concerns the scope and design of basic health-care institutions, the central institutions and social practices which form a health-care system'. Daniels has rightly argued that these macro decisions determine '(1) what kinds of health-care services will exist in a society, (2) who will get them, and on what basis, (3) who will deliver them, (4) how the burdens of financing them will be distributed, and (5) how the power and control of those services will be distributed" - p. 283-4) ${ }^{17}$. Isso foi mantido na $4^{\mathrm{a}}$. edição (p. 362) ${ }^{16}$.

$\mathrm{Na} 2^{\mathrm{a}}$. edição, passaram a discutir a questão de se o governo deveria investir na pesquisa de coração artificial para implante ou nos transplantes de coração propriamente ditos (p. 202-3) ${ }^{68}$. Na $3^{a}$. edição, incluíram ainda afirmação de que muitas questões sobre os transplantes de coração surgiram 
por causa de seus elevados custos - muito além do que muitas pessoas podem pagar, apesar de alguns planos cobrirem ("Major policy questions have arisen because the average cost for heart transplants is more than one hundred thousand dollars, well beyond the means of most citizens (although some insurance policies do cover heart transplants)" - p. 285) ${ }^{17}$.

Nesta $3^{a}$. edição também discutiram o embate entre utilidade e igualdade, dando o exemplo que questiona se transplantes de coração fariam parte do mínimo existencial ("[...] there will inevitably be debate about how trade-offs between utility and equality are to be made, about how much money should be available for health care, and about where it should be allocated within health care [...] it is not clear that under the decent-minimum rule justice requires society to provide funds to cover heart transplants [...]" - p. 286) ${ }^{17}$, o que foi mantido na $4^{a}$. edição (p. 342) ${ }^{16}$.

Nesse diapasão, também na $3^{a}$. edição, passaram a explicar que a "Força Tarefa em Transplantes de Órgãos" ("Task Force on Organ Transplantation") se baseou na continuidade dos tratamentos com transplantes de fígado e de coração e tomou como premissa que eles fazem parte do mínimo existencial ou apenas do nível adequado de saúde que a sociedade é obrigada a prover ("The first emphasizes the continuity between heart and liver transplants [...] accepted as part of the decent minimum or adequate level of health care that society is committed to provide" - p. 286) ${ }^{17}$. Tudo mantido na $4^{\mathrm{a}}$. edição (p. 373) ${ }^{16}$.

Acrecentaram, na $3^{a}$. edição, relato de que, em 1986, a "Força Tarefa em Transplantes de Órgãos" propôs acesso aos transplantes apenas a pacientes elegíveis sem condições de arcar com os custos dos procedimentos ou não cobertos pelas assistências médicas básicas estadunidenses, Medicare (assistência à saúde de alto custo, financiada pela seguridade social) ou Medicaid (assistência à saúde de baixo custo, financiada pelo governo federal) ("The federal Task Force on Organ Transplantation recommended in 1986 that "a public program should be set up to cover the costs of people who are medically eligible for organs transplants but who are not covered by primate 
insurance, Medicare, or Medicaid and who are unable to obtain an organ transplant due to the lack of funds" - p. 286) $)^{17}$ - o que foi mantido na $4^{\text {a }}$. edição (p. 373) ${ }^{16}$.

$\mathrm{Na} 3^{a}$. edição, incluíram explicação de que o "Força Tarefa em Transplantes de Órgãos" defendeu que não seria justo, sendo até mesmo explorador, solicitar a todas as pessoas que doem órgãos, se depois serão distribuídos de acordo com a capacidade de poder pagar pelo procedimento de transplante ("[...] the task force argued, it is unfair and even exploitative for the society to solicit people, rich and poor alike, to donate organs if those organs are then distributed on the basis of ability to pay" - p. 287$)^{17}$, mantido na $4^{\text {a }}$. edição (p. 373-4) ${ }^{16}$.

Também, na $3^{a}$. edição, acresceram explicação de que é difícil diferenciar a compra de um órgão da compra de um procedimento de transplante, já que o órgão será fornecido com o procedimento ("It is difficult to distinguish buying an organ for transplantation from buying an organ transplant procedure, when the organ is provided with the procedure" - p. 287$)^{17}$, o que se confirmou na $4^{\text {a }}$. edição (p. 373-4 $)^{16}$.

Introduziram, na $3^{a}$. edição, que, apesar de os Estados Unidos investirem mais de mil dólares por pessoa por ano em saúde, o pobre e o não segurado frequentemente não conseguem pagar ou ter de qualquer forma acesso à uma assistência minimamente adequada ("More than one thousand dollars per person is spent annually for health care in the United States, yet the poor and the uninsured often cannot afford or find access to minimally adequate care" - p. 276-7 $)^{17}$.

Assim, muitas propostas tradicionalmente apresentadas para amenizar esta situação não tem sido baseadas na justiça, mas nas virtudes da caridade, da compaixão e da benevolência em relação aos doentes ("Many traditional proposals of social assistance to alleviate this situation have been based not on justice but on the virtues of charity, compassion, and benevolence toward sick 
persons" - p. 276-7 $)^{17}$. Considerações mantidas na $4^{\mathrm{a}}$. edição (p. 348, 349$350)^{16}$.

Ainda na $2^{\mathrm{a}}$. edição, discutiam a dificuldade de estabelecer o que seria um acesso à assistência de saúde, afirmando que deveriam estar incluídos: igual acesso e direito a um mínimo existencial (p. 203-4) ( $^{68}$. Na $3^{\text {a }}$. edição, porém, afirmam também que, muitas vezes, o direito ao acesso à saúde não significa que toda e qualquer assistência deveria ser provida pelos outros, mas sim que nenhuma pessoa poderia ser impedida de alcançá-la ("Access to health care takes on several meanings in these discussions. Sometimes it means only that no one may be prevented from obtaining health care, not that any health care must be provided by others" - p. 278-9 $)^{17}$. Na $4^{\text {a }}$. edição, mantiveram o trecho (p. 355) ${ }^{16}$.

Excepcionalmente na $3^{a}$. edição, existia afirmação de que provar que existe um direito moral à assistência à saúde exige mais do que expor casos desesperadores, pois necessita de argumentação. Defendem que duas premissas morais deveriam ser trabalhadas: a da proteção social coletiva e a da justa oportunidade (" $[. .$.$] to show that there is a moral right to health care$ requires more than an arrayal of desperate cases. It requires moral argument. We believe two arguments provide sufficient grounds for the claim that there is a right to health care. Two main arguments are based on premises of (1) collective social protection and (2) the fair opportunity rule [...]' - p. 276) ${ }^{17}$.

$\mathrm{Na} 3^{\mathrm{a}}$. edição, enxertaram que a saúde pública é um bem social, enquanto a assistência à saúde é muito mais uma questão de bem privado ("[...] there are also relevant dissimilarities between health care and the aforementioned collective goods and services. In particular, these other goods and services pertain to what are generally considered social goods, such as the public health, whereas health care is largely a matter of the individual's private good" - p. 276) ${ }^{17}$, o que continuou no número seguinte (p. 351-2) ${ }^{16}$.

$\mathrm{Na} 3^{\mathrm{a}}$. edição, incluíram que a sociedade tem expectativa de receber, como retorno decente de seus tributos pagos, adequada assistência à saúde - 
eis que paga pela formação de médicos e pelo financiamento de pesquisas biomédicas. Existem, inclusive, mais investimentos na pesquisa e no treinamento de assistência do que na saúde propriamente dita ("[...] society's right to expect a decent return on the investment it has made in the education of physicians, the funding of biomedical research, and other parts of the medical system that pertain dominantly to health care as distinct from public health. The return we expect on this taxed investment is adequate individual health-care protection [...] we fund even more training and research in medicine than in public health" - p. 276-7 $)^{17}$. Na $4^{\text {a }}$. edição, mantiveram a afirmação (p. 351-2) ${ }^{16}$.

Somente na $3^{\mathrm{a}}$. edição, questionavam se as doenças resultantes de comportamentos deletérios deveriam ser cobertas pela assistência à saúde, tal qual já haviam feito na $2^{a}$. (p. 189) ${ }^{17}$, citando, como exemplos, AIDS, câncer de pulmão e doenças do fígado ("These questions of forfeiture have emerged about the societal coverage of health care for patients whose diseases may be the result of their personal life-styles or individual actions. Examples include patients with AIDS as a result of sexual activities or intravenous drug use, patients with lung cancer as a result of smoking cigarettes, and patients with liver disease as a result of heavy consumption of alcohol" - p. 280-1) ${ }^{17}$.

Já na $2^{a}$. edição (p. 208-9) ${ }^{68}$, elencavam razões para se considerar quase impossível apontar as responsabilidades por cada uma das necessidades médicas. Nesta $2^{\mathrm{a}}$. edição, citando a loteria natural, as práticas sociais e as escolhas individuais apenas ${ }^{68}$.

$\mathrm{Na} 3^{\mathrm{a}}$., somaram os fatores causais, a complexidade das doenças, as limitações do conhecimento, as predisposições genéticas, as ações pessoais e as condições sociais e de meio ambiente ("[...] it is virtually impossible to isolate causal factors for many of the most critical cases of ill health because of the complexity of causal links and the limitations of our knowledge [...] Medical needs often result from the conjunction of genetic predispositions, personal actions, and environmental and social conditions" - p. 281-217. Além disso, esclareceram que vários riscos de doença não são conhecidos ainda por todos, ou mesmo pelas pessoas em geral ("Some of the risks of disease, injury, and ill 
health are not known at all or are not known by particular individuals" - p. 282) ${ }^{17}$ - preservado na $4^{\mathrm{a}}$. edição (p. 359) ${ }^{16}$.

$\mathrm{Na} 2^{\mathrm{a}}$. (p. 208) ${ }^{68}$ e apenas até a $3^{\mathrm{a}}$. edição, citavam Veatch, que afirma que seria justo tratar de forma melhor as pessoas que ficaram doentes involuntariamente chegando a defender que seria injusto tratá-las igual (Robert Veatch contends has argued that it is fair [...] if persons in need of health services resulting from true, voluntary risks are treated differently from those in need of the same services for other reasons. In fact, it would be unfair if the two groups were treated equally" - p. 281) ${ }^{17}$.

Ainda na $2^{\mathrm{a}}$. edição, afirmavam que estilos de vida arriscados podem, na realidade, requerer menores cuidados de saúde e que uma análise ampla de custo-benefício poderia desprestigiar as políticas de saúde interventivas nestes grupos de risco. Referiam Leichter, o qual defende que pode se esperar um aumento, ao invés de uma diminuição, nos custos de saúde como resultado de se evitar riscos em saúde (p. 208) ${ }^{68}$.

Por outro lado, na $3^{a}$. edição, afirmam que talvez as pessoas pertencentes a grupos de risco requeiram menos recursos médicos porque tendem a morrer mais cedo e mais rápido do que os que vivem mais, desenvolvendo doenças crônicas ("Some risk-taking may require less rather than more medical care, because it results in earlier and quicker deaths than might occur if individuals lived longer and developed a chronic debilitating condition" - p. 282-3) ${ }^{17}$. Além disso, a maior razão para se discutir direitos na assistência à saúde é o crescente aumento dos seus custos ("A major reason for the current debates about forfeiture of rights to health care is the rising cost of health care" - p. 282-3) $)^{17}$. Tudo mantido na $4^{\mathrm{a}}$. edição (p. 382).

$\mathrm{Na} \mathrm{2a}$. edição, já argumentavam que mesmo que fosse possível estabelecer quais hábitos deletérios adotados pela pessoa resultaram em doença, para saber se ela possui direito à assistência de saúde ou não, isso poderia causar um comprometimento do princípio do respeito pela autonomia e de sua regra de privacidade (p. 208-9 $)^{68}$. Somente até a $3^{a}$., repetem isso, 
incluindo a regra da confidencialidade ("Even if it were possible to determine with accuracy the causal conditions of particular health problems, society would at some points have to compromise the principle of respect for autonomy and derivative rules of privacy and confidentiality" - p. 282) ${ }^{17}$.

$\mathrm{Na} 2^{\mathrm{a}}$. edição (p. 208), diziam que não seria paternalista proteger os recursos financeiros da sociedade, como, por exemplo, tributando as pessoas que assumem estilos de vida arriscados (como os alcoolistas e os fumantes), assim, cobrindo os seus maiores gastos em saúde ${ }^{68}$. Na $3^{\text {a }}$. edição, por sua vez, passaram a defender que as pessoas de grupos de riscos deveriam contribuir mais a seguros específicos ou pagar tributos especiais por suas condutas de risco. Como exemplo, elevando-se a taxação dos cigarros. Isso redistribuiria os custos de saúde de maneira justa e não desrespeita o princípio da autonomia destas pessoas ("Risk-takers might be required to contribute more to particular pools [...] or to pay a tax on their risky conduct - such as an increased tax on cigarettes. These requirements may fairly redistribute the burdens of the costs of health care and they may deter risky conduct without disrespecting the principle of respect for autonomy" - p. 283) ${ }^{17}$. O que foi mantido na $4^{\text {a }}$. edição (p. 360 $)^{16}$.

Iniciaram, na $2^{\mathrm{a}}$. edição (p. 204), discussão sobre incremento da qualidade de vida e prevenção, que podem ser mais eficientes na promoção de saúde do que a medicina exclusivamente curativa ${ }^{68}$. Nesta edição (p. 284), citaram estudos que comprovam isso, chegando a afirmar que alocar recursos na assistência à saúde ou na tecnologia em detrimento de se melhorar a qualidade de vida das pessoas seria o mesmo que "desalocar" ("misallocate" p. 204$)^{68}$.

Apenas até a $3^{a}$. edição, citam ainda estudos que comprovam que outras condições, como a qualidade de vida, são mais importantes do que o próprio implemento da saúde. ("These studies may only indicate that medical care is not as statistically significant for health as some other conditions in the society, such as the standard of living" - p. 284) ${ }^{17}$. 
A partir da $3^{a}$. edição, ao lado da vacinação contra poliomielite, que já estava presente na $2^{a}$. (p. 204-5) ${ }^{68}$, incuíram o exemplo da odontologia preventiva como modelo de sucesso na prevenção ("Polio vaccine and preventive dentistry are staple examples of success in prevention [...]' - p. 287$8)^{17}$ - mantendo na $4^{\text {a }}$. edição (p. 363-4 $)^{16}$.

$\mathrm{Na} 3^{\mathrm{a}}$. edição, ao mesmo tempo em que passam a afirmar que princípios utilitários preferem estratégias preventivas, porque maximizariam a utilidade social, $B \& C$ incluíram relato de que tem se questionado o modelo preventivo porque, apesar de evitar doenças futuras dispendiosas, faz aumentar o número de atendimentos na medida em que as pessoas vivem mais ("Utilitarian principles require opting for the preferability of preventive strategies if they would maximize social utility [...] it has been argued [...] that every public health dollar targeted at poorer communities for preventive measures in prenatal care saves many times that amount in later care [...] it has been argued in recent health policy literature that preventive medicine often only prolongs health-care costs to a later age and, in the long run, may be more rather than less costly" p. 288) ${ }^{17}$.

$\mathrm{Na} 4^{\mathrm{a}}$. edição, acrescentaram que tudo o que é gasto nas comunidades pobres com prevenção, como assistência pré-natal, salva inúmeras vezes mais no futuro. O que levou B\&C a ter a "intuição moral" ("moral intuition") de que existirá um conflito entre alocar no imediato salvamento de vidas ou alocar para prevenir que mais pessoas venham a precisar disso (p. 364) $)^{16}$.

$\mathrm{Na} 3^{\mathrm{a}}$. edição, mantendo na $4^{\mathrm{a}}$. (p. 290) ${ }^{16}$, introduziram a diferença entre alocação, uma destinação de recursos escassos, mas de forma maleável; e racionamento, uma destinação de recursos escassos, de maneira mais dura (“[...] allocating scarce medical resources, a formulation that implied hard but generally manageable choices of a largely pragmatic nature [...] rationing scarce medical resources, a harsher term that connotes emergency [...]" - p. 290) $)^{17}$. 
Apenas na $3^{a}$. edição, explicavam que existe a necessidade de selecionar pacientes em situações de escassez. Diferente de muitos acordos contratuais, esta questão não pode ser resolvida pelo princípio do respeito à autonomia, porque não se trata de uma escolha dos pacientes ("Who shall live when not everyone can live?' Unlike many contractual arrangements between patients and physicians, this question cannot be resolved by the principle of respect for autonomy, because it is not answerable by the patient" - p. 290 $)^{17}$.

Mais adiante, ainda unicamente na $3^{a}$. edição, enfatizaram a necessidade de se focar em características moralmente relevantes na seleção de pacientes ("The major debates focus on which characteristics are morally relevant and which are morally irrelevant in the selection of patients" - p. 291) ${ }^{17}$.

$\mathrm{Na} 3^{a}$. edição, enxertaram afirmação de que o critério social na seleção de pacientes é inapropriado ao uso em programas que recebem recursos públicos ("Critics held that these "social" criteria are inappropriate for use in programs receiving public funds" - p. 294) ${ }^{17}$ - mantido na edição seguinte ( $p$. 380) ${ }^{16}$.

$\mathrm{Na} 3^{\mathrm{a}}$. edição, também introduziram que os critérios de busca e seleção de pacientes receptores de transplantes de coração e a dificuldade de determinar se representam uma utilidade médica ou uma utilidade social acarretam a necessidade de determinação de se buscar maximizar o bem-estar dos pacientes ou da sociedade ("The debate about the criteria for screening and selecting heart transplant recipients has focused to a great extent on whether those criteria represent medical utility or social utility. In judgments of medical utility, physicians and others try to maximize the welfare of patients, whereas in judgments of social utility, they try to maximize the welfare of society" - p. 294 $)^{17}$. Isso foi mantido na $4^{\text {a }}$. edição (p. 380-1 $)^{16}$.

Na $3^{a}$. edição, incluíram relato de que a "Força Tarefa em Transplantes de Órgãos" determinou que critérios como raça e sexo seriam injustos na seleção de pacientes receptores de trasnplantes. B\&C relatam que o debate é evidente em três critérios: idade, estilo de vida e meio social ("The Task Force 
on Organ Transplantation ruled out criteria such as race and sex as unjust [...] The debate about such criteria is evident in three examples: age, life-style, and social network of support" - p. 294-5) ${ }^{17}$. Isso foi mantido na $4^{a}$. edição ( $p$. $381)^{16}$.

Unicamente na $3^{a}$. edição, explicavam que o uso da idade, como critério de seleção de pacientes, poderia ser indiciativo da probabilidade de sobrevivência - relevante em uma cirurgia maior ("[...] age may be a rough indicator of the probability of surviving a major operation and thus may be medically relevant" - p. 295) ${ }^{17}$.

Somente na $3^{a}$. edição, também alegavam que as pessoas geralmente pertencem a vida toda à mesma raça e sexo, mas que passarão por todas as idades se viverem o suficiente ("People generally remain in the same race and sex throughout their lives [...] but they pass through all ages if they live long enough" - p. 295) ${ }^{17}$.

Exclusivamente na $3^{a}$. edição, falavam sobre os estilos de vida das pessoas, que determinam se os riscos de vida voluntariamente assumidos poderiam se tornar um pressuposto do direito à vida ("[...] when we considered whether voluntary risk-taking constituted a forfeiture of the right to health care $[\ldots]^{\prime \prime}-$ p. 295) ${ }^{17}$.

Somente na $3^{a}$. edição, explanavam o critério meio social, incluindo a família, que poderia indicar o valor que aquela pessoa representa para os outros, fato que também pode ser medicamente relevante no sucesso de um transplante, particularmente, no cuidado pós-operatório, o que, por sua vez, tem impacto na utilidade médica, nas vertentes eficiência e eficácia no uso de um órgão que fora previamente doado ("[...] a social network of support, including the family, may indicate the patient's social value to others, but it may also be medically important in the overall success of the transplantation, particularly in posttransplant care, and thus may have an impact on medical utility in the sense of an effective and efficient use of a donated organ" - p. 295$6)^{17}$, mais adiante, afirmando que julgamentos de utilidade médica podem 
frequentemente mascarar julgamentos mais profundos de utilidade social ("[...] judgments of medical utility can often mask deeper judgments of social utility" p. 296) ${ }^{17}$.

$\mathrm{Na} 3^{\text {a }}$. edição apenas, contavam o caso da inicial distribuição de AZT (da marca Retrovir), uma droga que diminuía o progresso da AIDS e que era o único tratamento aprovado. A empresa que o comercializava possuía quantidades limitadas e podia fixar os preços como quisesse. $\mathrm{O}$ custo inicial foi estabelecido em dez mil dólares por ano por paciente, um preço alto o suficiente para excluir alguns. Todavia, mesmo assim, número suficiente podia arcar com os custos, de modo a fazer com que a empresa utilizasse também um critério de alocação: o das pessoas em estado mais grave. A empresa acabou sendo criticada pelos altos preços e por não ter escolhido pessoas em condições de saúde melhores, que permitissem seus retornos ao trabalho com mais rapidez ("[...] distribution of AZT (or Retrovir), a drug that slows the progress of the AIDS virus and that was the only approved treatment for AIDS. The manufacturing company had limited quantities and was free to set its price for the drug. The initial cost was established as ten thousand dollars per year per patient, a price high enough to exclude some patients. However, a sufficient number of patients could afford the drug so that the limited supply required [...] to use further criteria of allocation. It chose to allocate first to the sickest patients. The company was heavily criticized on grounds that the price was unreasonably high [...] and on grounds that the less sick patients could return more easily to productive lives than the sickest patients" - p. 292-3) ${ }^{17}$.

$\mathrm{Na} 3^{a}$. edição, incluíram explicação de que os padrões e procedimentos da seleção final de pacientes para tratamentos escassos são mais controversos do que os de uma triagem inicial. Muitos critérios sociais e de loteria já foram usados, mas o mais utilizado ainda é o de "quem chegar primeiro" - "first come, first served" ("The standards and procedures of final selection from screened candidates have been even more controversial than those for the initial screening of potential recipients [...] In effect, however, all centers used one form of the rule of 'first come, first-served' [...]" - p. 296) ${ }^{17}$ passagem mantida na $4^{a}$. edição (p. 381-2) ${ }^{16}$. 
$\mathrm{Na} 3^{\mathrm{a}}$. edição, acrescentaram que é moralmente imperativo se considerar a utilidade médica, em outras palavras, o bem-estar de pacientes com necessidade de tratamento ("[...] it is morally imperative to consider medical utility, understood as the maximization of the welfare of patients in need of treatment" - p. 297-8) ${ }^{17}$. Afirmam que esta abordagem não viola o princípio da justiça, apesar de haver certas dificuldades, pois tanto a necessidade quanto o prognóstico são critérios incertos ("Although this approach does not violate principles of justice, there are difficulties. Both need and prospect of success are value-laden concepts [...]' - p. 297) ${ }^{17}$. Oportunidade (“chance”) e ordem de chegada ("queuing”), segundo B\&C, são critérios baseados na justiça enquanto justa igualdade de oportunidade ("The use of chance and queuing is based on justice as equality and fair opportunity" - p. 297-8) ${ }^{17}$. Isso foi mantido na $4^{a}$. edição (p. 382) ${ }^{16}$.

$\mathrm{Na} 3^{\mathrm{a}}$. edição, começaram a dizer que muitos autores criticam que o uso de mecanismos impessoais seria uma irresponsável maneira de se fugir de uma decisão. Contudo, B\&C discordam, porque estes critérios poderiam ser justificados tanto por perspectivas deontológicas quanto por de regras utilitárias, representando modos de se expressar justa oportunidade quando os pacientes são igualmente habilitados à vaga ("Some critics [...] that the use of impersonal mechanisms is an irresponsible refusal to make a decision, but we believe the decision to use such impersonal mechanisms can be justified by either deontological or rule-utilitarian perspectives. Both can be ways to express fair opportunity when patients are roughly equal in medical utility" - p. 298) ${ }^{17}$. B\&C também criticam o uso da ordem de chegada quando os primeiros acabam por preterir aqueles que mais necessitam ("Does 'first come, first served' imply that those already receiving treatment have absolute priority over those who arrive later but have either more urgent needs or better prospects of success?" - p. 298 $)^{17}$. Tudo mantido na $4^{\mathrm{a}}$. (p. 383) ${ }^{16}$.

$\mathrm{Na} 2^{\mathrm{a}}$. edição (p. 214) ${ }^{68}$, quase nas mesmas palavras e somente até a $3^{a}$., afirmavam que algumas pessoas podem não entrar na fila a tempo, por questões de demora na procura por tratamento, inadequado ou ineficiente 
cuidado médico, demora na marcação ou evidente discriminação (“[...] some people may not [...] enter the queue or the lottery because of such factors as slowness in seeking help, inadequate or incompetent medical attention, delay in referral, ou overt discrimination" - p. 298-9) ${ }^{17}$.

$\mathrm{Na} 3^{\mathrm{a}}$. edição, passaram a afirmar que um argumento a favor da seleção social-utilitária é que as instituições de saúde e o seu pessoal são garantidores da sociedade e, portanto, devem considerar as futuras possíveis contribuições dos pacientes. Assim, Rescher defendia que se uma sociedade investe um recurso escasso em uma pessoa em detrimento de outra, deve buscar o retorno deste investimento ("One argument in favor of social-utilitarian selection is that medical institutions and personnel are trustees of society and thus should consider the probable future contributions of patients in need of scarce lifesaving resources [...] Nicholas Rescher contends, in its allocation [...] society 'invests' a scarce resource in one person as against another and is thus entitled to look to the probable prospective 'return' on its investment" - $\mathrm{p}$. $299)^{17}$. O que foi conservado na $4^{a}$. edição (p. 384-5 $)^{16}$.

A conclusão presente na $3^{a}$. edição (p. 301) ${ }^{17}$ representa uma reescritura da existente na $2^{a}$. edição (p. 216-217) $)^{68}$, onde explicavam que não se deve utilizar apenas uma teoria da justiça, mas várias, já que cada uma delas foi construída sob diferentes concepções absorvendo cada apenas parte das diversidades que a vida envolve; que as teorias parecem opostas, apesar disso, nenhuma sociedade consegue seguir unicamente uma delas, porque nenhuma é capaz de traduzir tanta diversidade com unicidade; e que, hoje, existem várias teorias de justiça plausíveis e igualmente viáveis.

\section{Alterações da $4^{\mathrm{a}}$. frente à $3^{\mathrm{a}}$. e à $5^{\mathrm{a}}$. edição}

$\mathrm{Na} 4^{\mathrm{a}}$. edição, o capítulo que até então se chamava "The Principle of Justice" (O Princípio da Justiça) passou a apenas "Justice" (Justiça). Os tópicos "The Concept of Justice" (O Conceito de Justiça), "Theories of Justice" (Teorias de Justiça) e "Fair Opportunity" (Oportunidade Justa) e "The Right to a 
Decent Minimum of Health Care" (O Direito a um Mínimo Decente em Saúde) foram os únicos a permanecerem intactos. O tópico "Principles of Justice" (Princípios de Justiça) foi retirado. O "Priorities in the Allocation of Health-Care Resources" (Prioridades na Alocação de Recursos em Saúde) foi desdobrado em dois novos: "The Allocation of Health-Care Resources" (A Alocação de Recursos de Saúde) e "Rationing through Priorities in the Health Care Budget" (Racionando por meio de Prioridades no Plano de Assistência de Saúde). Por fim, o tópico "Rationing Health Care" (Racionando em Assistência de Saúde) foi substituído por "Rationing Scarce Treatments to Patients" (Racionando Tratamentos Escassos aos Pacientes) ${ }^{16}$.

$\mathrm{Na} 3^{\mathrm{a}}$. edição, havia referência ao exemplo das técnicas de duplo-cego, que, segundo os autores, é erroneamente relacionada ao princípio da justiça, o qual condena estas pesquisas por injustamente negarem informação aos pacientes. Na verdade, deveriam ser relacionadas ao princípio da autonomia (p. 256-7 $)^{17}$. Na $4^{a}$. edição, isso foi retirado ${ }^{16}$.

$\mathrm{Na} 3^{\mathrm{a}}$. edição, já explicavam o que representava a justiça distributiva, uma tentativa de se estabelecer uma conexão entre as propriedades ou as características das pessoas e a distribuição moralmente correta de benefícios e obrigações na sociedade (p. 258) ${ }^{17}$. Na $4^{a}$. edição, porém, explicam justiça distributiva como a justa, equitativa e apropriada distribuição determinada por normas justificadas que estruturam os termos da cooperação social, além disso, incluíram temas sobre benefícios e obrigações como propriedade, recursos, tributação, privilégios e oportunidades. Por fim, afirmaram que várias instituições públicas e privadas estão envolvidas, incluindo o governo e o sistema de assistência à saúde ("The term distributive justice refers to fair, equitable, and appropriate distribution determined by justified norms that structure the terms of social cooperation [...] benefits and burdens, such as property, resources, taxation, privileges, and opportunities. Various public and private institutions are involved, including the government and the health care system" - p. 327) ${ }^{16}$. Na $5^{\text {a }}$. edição, mantiveram as afirmações (p. 226), retirando apenas a sobre as várias instituições envolvidas ${ }^{69}$. 
$\mathrm{Na} 4^{\text {a }}$. edição, incluíram fala sobre os gastos em saúde nos Estados Unidos, dizendo que as pessoas que usam pouco os serviços acabam sendo obrigadas a consumir mais do que precisam, pagando por mensalidades que não gastam ("[...] When parties who are insured pay far less than the value of what they consume, they will consume more than they otherwise would" - p. $366)^{16}$. Isso foi mantido na $5^{\text {a }}$. edição (p. 253-4 $)^{69}$.

$\mathrm{Na} 4^{\mathrm{a}}$. edição, explicavam que recursos de saúde não são sinônimo de recursos médicos, pois vão além, assim, os planos de saúde extrapolam em muito os para de assistência à saúde ("The term health resources, then, is not a substitute for medical resources, and the budget for health vastly exceeds the portion for health care" - p. 363) ${ }^{16}$, o que foi conservado na edição seguinte ( $p$. $251)^{69}$.

$\mathrm{Na} 4^{a}$. edição, acrescentaram a origem militar da palavra "racionamento" ("rationing"), que não tinha conotação de desastre ou de emergência, apenas de dividir porções entre os militares ("Rationing, for example, originally did not suggest harshness or an emergency. It meant a form of allowance, share, or portion, as when food is divided into rations in the military" - p. 365$)^{16}$.

Da mesma forma, os vários sentidos da palavra supra: negativa por falta de recursos, de forma a estar relacionado com a falta de capacidade para pagar; limites de política social: impossibilidade de se adquirir algo que escolheu e que pode pagar; divisão equitativa, mas quem pode pagar por mais não é impedido de fazer isso ("Rationing now has three primary meanings [...] 'denial from lack of resources' [...] including health care, are to some extent rationed by ability to pay [...] social policy limits: [...] government determines an allowance or allotment, and those who can afford the good are denied access beyond the allotted amount [...] an allowance or allotment is determined and distributed equitably, but those who can afford additional goods are not denied access beyond [... $]^{\prime}-$ p. 365$)^{16}$. Tudo isso foi sustentado na $5^{\text {a }}$. edição ( $p$. $253)^{69}$. 
Sobre o princípio da "capacidade para pagar", na 3a . edição, destacavam que se baseia em uma justiça libertária, que não se preocupa em incrementar as políticas públicas, mas sim na capacidade de escolha (p. 266) ${ }^{17}$. Na $4^{\mathrm{a}}$., acrescentaram que a assistência à saúde, nesta concepção, não representa um direito. Também, que a privatização do sistema de saúde é um valor protegido porque, nestas sociedades de justiça libertária, existem direitos de propriedade e de liberdade ("Health care is not a right under this conception, and privatization in the health care system is a protected value [...] libertarian interpretation of justice [...] The just society protects rights of property and liberty [... ." - p. 336) ${ }^{16}$. Tudo mantido na $5^{\text {a }}$. edição (p. 232) ${ }^{69}$.

$\mathrm{Na} 3^{\mathrm{a}}$. edição (p. 287 $)^{17}$, continuando apenas até a $4^{\mathrm{a}}$., explicavam de que o "Força Tarefa em Transplantes de Órgãos" pregou que não seria justo, sendo até mesmo explorador, solicitar a todas as pessoas que doem órgãos, se depois serão distribuídos de acordo com a capacidade de pagar o procedimento de trasnplante ("[...] the task force argued, it is unfair and even exploitative for the society to solicit people, rich and poor alike, to donate organs if those organs are then distributed on the basis of ability to pay" - $\mathrm{p}$. $373-4)^{16}$.

$\mathrm{Na} 4^{\text {a }}$. edição, introduziram o dizer de Daniels, que afirma que um sistema de saúde justo deve se basear no princípio de Rawls da "justa igualdade de oportunidade" - "fair equality of opportunity" ("[...] Norman Daniels argues for a just health care system based centrally on a Rawlsian principle of 'fair equality of opportunity" - p. 340) ${ }^{16}$. Isso foi mantido na $5^{\text {a }}$. edição (p. 234) ${ }^{69}$.

Apenas na $4^{\text {a }}$. edição, aclaravam que a regra da justa oportunidade impede que critérios de gênero e de raça sejam utilizados para impedir as pessoas de acesso à saúde ("The fair-opportunity rule excludes policies that deprive women and racial groups of health services because of gender and race" - p. 345) ${ }^{16}$.

A partir da $4^{\mathrm{a}}$. edição, sobre a discriminação no acesso à saúde, citaram de estudos recentes que apontam que negros e mulheres têm menos acesso a 
várias formas de assistência à saúde, em especial, por questões econômicas, e que, sobre o exemplo do antígeno leucocitário humano, afirmam que o uso da compatibilidade tecidual como forma de determinar a prioridade nas listas também pode gerar discriminação, eis que a maioria dos doadores é branca. ("Recent studies indicate that blacks and women still have less access to various forms of health care than do white males, in part because of socioeconomic factors [...] It appears that discrimination against blacks, other minorities, and women has already occurred at the point of admission to waiting lists, and assigning priority to tissue matching can produce further discriminatory effects for minorities. Most organ donors are white, and certain HLA phenotypes are different in white, black, and Hispanic populations" - p. $346)^{16}$, presentes na edição subsequente (p. 238-9 $)^{69}$.

$\mathrm{Na} 4^{\mathrm{a}}$. edição, passaram a comentar sobre suspeitas de que as minorias estejam servindo de doadores potenciais de órgãos, fazendo com que as doações nestes grupos seja escassa ("Suspicion among minorities about the justice of the health care system is a factor in their lower rate of cadaveric organ donation, because they worry about exploitation, as sources of organs for whites" - p. 346-7) ${ }^{16}$, mantendo na $5^{\text {a }}$. edição (p. 239) ${ }^{69}$.

$\mathrm{Na} 4^{a}$. edição, incluíram afirmação de que há boas evidências de que homem e mulher são tratados de maneira diferente por razões que parecem não relacionadas às suas condições médicas. Indicam alguns estudos segundo os quais as mulheres vão mais vezes ao médico e realizam mais procedimentos por visita do que os homens, contudo, existem disparidades em relação a três áreas: diagnóstico de câncer de pulmão, diagnóstico e tratamento de doença cardíaca, e acesso a transplantes de rim. O que não pode ser inteiramente atribuído a diferenças biológicas ("Some studies indicate that women have more physician visits per year than men and receive more services per visit, but gender disparities still appear in three areas: (1) diagnosis of lung cancer, (2) diagnosis and treatment of cardiac disease, and (3) access to kidney transplantation. These disparities cannot be accounted for entirely by biological differences [...] good evidence exists that men and women are treated differently for reasons that appear unrelated to their medical conditions [...] 
There is ongoing debate about whether these procedures are overused in men, underused in women, or both" - p. 347) ${ }^{16}$. Isso foi mantido na $5^{\text {a }}$. edição (p. $236)^{69}$.

$\mathrm{Na} 4^{a}$. edição, adicionaram que, às pessoas com saúde frágil, com doenças preexistentes ou com histórico familiar de doenças que sugerem maiores gastos futuros com saúde, frequentemente, é negado cobertura, oferecido menos cobertura ou é cobrado mais caro por planos de saúde ("Those with poor health or preexisting conditions or family histories that suggest the potential for expensive future claims are often denied coverage under exclusion clauses (or are offered only inferior and more expensive coverage)" - p. 348-9) ${ }^{16}$, passagem contida na $5^{\text {a }}$. edição (p. 240) ${ }^{69}$.

Apenas na $4^{\mathrm{a}}$. edição, explicavam que o sistema de seguridade americano é injusto porque se baseia nos empregadores, assim, os de médio e grande porte podem proporcionar melhores coberturas, até mesmo porque 0 governo oferece subsídios. Pessoas com empregadores pequenos frequentemente não são asseguradas e, por causa das cláusulas excludentes, acabam existindo pessoas que, a despeito de serem seguradas, são menos seguradas ou apenas ocasionalmente seguradas ("[...] constitute one subgroup of those two, though insured, are underinsured [...] Other persons are occasionally insured, sometimes uninsured and sometimes underinsured [...]"p. 349$)^{16}$.

Passaram a explicar também, na $4^{a}$. edição, que a elegibilidade para Medicaid varia de acordo com o Estado americano e que nenhum dentre os cinquenta estados cobre todos os cidadãos abaixo da linha da pobreza ("[...] eligibility for Medicaid varies dramatically across states, and not one state among fifty covers all citizens who are below the poverty line" - p. 349) ${ }^{16}$. O que foi mantido na $5^{\text {a }}$. edição (p. 241) ${ }^{69}$.

Exclusivamente até a $4^{\mathrm{a}}$. edição, repetem os argumentos da $3^{\mathrm{a}}$. (p. 276$7)^{17}$, explanando que muitas propostas para melhorar este sistema (Medicare/Medicaid) foram baseadas não na justiça, mas nas virtudes da 
caridade, compaixão e benevolência pelas pessoas doentes. Contudo, na era da alta tecnologia e dos altos custos, estes ideais se mostraram inadequados à tarefa de lidar com muitas necessidades médicas. Os antigos modelos de assistência voluntária, gradualmente, deram vez a um modelo amplamente aceito de um obrigatório direito a assistência de saúde baseada na justiça ("Many proposals to alleviate this situation have been based not on claims of justice, but rather on the virtues of charity, compassion, and benevolence toward sick persons [...] But in the new era of high technology and commensurately high costs, these ideals have proved inadequate to the task of meeting many health care needs. The older models of voluntary assistance have gradually given way to a widely accepted model of an enforceable right to health care based in justice" - p. 349-50) ${ }^{16}$.

Unicamente na $4^{a}$. edição, diziam que os hospitais, mesmo com tantas regulamentações tentando prevenir abusos, vão continuar achando formas de negar atendimento a indigentes, pois estas regulamentações apenas vão de encontro aos efeitos visíveis do sistema de saúde, não atingindo as camadas mais profundas do problema, o que irá continuar até que haja forte incentivo financeiro e que até que exista um sistema de seguridade adequado e acesso equitativo ("Many state statues have been passed to prevent abuses [...] treat only the visible effects of the health care system, not the more difficult underlying causes. Distressed health care institutions will find ways of preventing admission by indigent patients as long as a strong financial incentive exists to do so [...] These motivations and actions will persist until a system of adequate insurance and equitable access is in place" - p. 350) ${ }^{16}$.

Acrescentaram, na $4^{\mathrm{a}}$. edição, como sugestão de política de proteção social, programas de proteção ao meio ambiente e sanitárias ("[...] including programs of environmental protection and sanitation" - p. 351$)^{16}$. Isso foi mantido na $5^{\text {a }}$. (p. 242) ${ }^{69}$.

$\mathrm{Na} 4^{\mathrm{a}}$. edição, introduziram a expressão "bem comum" ("common good" - p. 337-8) ${ }^{16}$. Mais adiante a explicam, como sendo um ponto básico de referência para a deliberação pública sobre como estabelecer o mínimo 
existencial ("The common good is a basic point of reference for public deliberation about how to establish the decent minimum" - p. 356-7) ${ }^{16}$.

Já na $5^{\mathrm{a}}$., associaram o "bem comum" a escolhas prudentes, as quais determinariam o que um sistema universal de saúde deveria assegurar a todos. Estabelecer seus contornos precisos, invariavelmente, envolverá embates, pois nenhum direito irá se sobrepor a todas as reivindicações concorrentes de utilidade social ou de bem comum quando questões maiores de macroalocação estão em jogo. Estas questões são muito complexas para uma teoria ética resolver (p. 246-7) ${ }^{69}$.

$\mathrm{Na} 4^{a}$. edição, introduziram a justiça comunitária como uma das teorias de base do princípio da justiça. Explicam que alguns comunitaristas se abstraem da noção de justiça se baseando na solidariedade, a qual representa tanto uma virtude pessoal de comprometimento quanto um princípio de moralidade social baseado nos valores compartilhados por um grupo ("Some communitarians eschew the language of justice and adopt the language of solidarity, which is both a personal virtue of commitment and a principle of social morality based on the shared values of a group" - p. 338) ${ }^{16}$, passagem conservada na $5^{\mathrm{a}}$. edição (p. 233) ${ }^{69}$.

$\mathrm{Na} 3^{a}$. edição, explicavam que as necessidades de assistência à saúde eram determinadas por tudo aquilo que seria necessário para conquistar, restaurar ou manter adequados níveis de "funcionamento típico das espécies" "species-typical" (p. 269-270) $)^{17}$. Na 4ª edição, afirmaram o mesmo, mas também que as formas de assistência médica que possuem efeitos significativos sobre prevenção, limitação ou compensação das reduções no normal "funcionamento típico das espécies" deveriam receber prioridade no trabalho das instituições de saúde e na alocação da assistência de saúde ("Forms of health care that have a significant effect on preventing, limiting, or compensating for reductions in normal species functioning should receive priority in designing health care institutions and allocating health care" - p. 340$1)^{16}$. Isso tudo foi mantido na $5^{a}$. edição (p.234 $)^{69}$. 
Apenas até a $4^{\mathrm{a}}$. edição, assim como havia na $3^{\mathrm{a}}$. (p. 299 $)^{17}$, comentavam Rescher, que defende que se a sociedade investe um recurso escasso em uma pessoa, em detrimento de em outra, deve respeitar um prognóstico de retorno de seu investimento. Argumento que tem mérito, mas que poderia ser criticado sob diversas perspectivas de justiça (enquanto o que seria justo) e de utilidade ("Nicholas Rescher contends, "in its allocation [...] society 'invests' a scarce resource in one person as against another and is thus entitled to look to the probable prospective 'return' on its investment". This argument has merit, but it can be criticized from several perspectives of fairness and utility" - p. 384-5) ${ }^{16}$.

O "Plano de Reforma da Saúde de Oregon" ("Oregon's Health Budget") ganhou diversos parágrafos na $4^{\text {a }}$. edição ${ }^{16}$. Sobre ele, incluíram que estabeleceu uma "lista de prioridades" ("priority list") de centenas de procedimentos médicos no Medicaid, elencando os tratamentos do mais importante ao menos importante, baseado em informação sobre o bem-estar após os tratamentos ("[...] 'priority list' of hundreds of medical procedures for Medicaid [...] The list ranged 'from the most important to the least important' services, based in part on data about quality of well-being after treatment" - $p$. $367)^{16}$. Na $5^{a}$. edição, ao lado do critério do bem-estar após os tratamentos, implementaram o de "custo-efetividade" ("cost-effectiveness" - p. 256), porém, no que tange à lista de prioridades, foi removida ${ }^{69}$.

Apenas na $4^{\text {a }}$. edição, havia crítica ao "Plano de Reforma da Saúde de Oregon", que favorece inúmeros tratamentos relativamente pequenos em detrimento de outros salvadores de vida ("Critics contend that the Oregon Plan contains serious defects because it favors many relatively minor treatments over lifesaving treatments [...]" - p. 368) ${ }^{16}$.

Exclusivamente na $4^{\text {a }}$. edição, diziam que as pessoas ficarão desapontadas ao perceber que o padrão da assistência fornecida é "decente" e não "excelente", mesmo no "Plano de Reforma da Saúde de Oregon", onde se percebe que seria surreal esperar um padrão de assistência melhor do que assistência adequada ("Although some parties will be distressed to learn that 
the standard is "decent" care rather than "optimum" care [...] Oregon health plan, we will see that it is unrealistic to expect a higher level than adequate care" - p. 356) ${ }^{16}$.

$\mathrm{Na} 3^{\mathrm{a}}$. edição, afirmavam que, se as pessoas não são responsáveis por seu processo de envelhecimento, seria injusto alocar assistência prioritária a jovens antes de idosos (p. 272) ${ }^{17}$. Isso foi retirado na $4^{a}$. edição, que, contudo, apenas nesta edição, refenciou Daniels, que defende que decisões prudentes deveriam fazer uso do critério da idade de forma a levar em consideração não apenas um momento na vida, mas toda a sua duração, alocando-se os recursos de forma prudente através de todos os seus estágios de maneira a aumentar as chances de se obter uma normal duração da vida ("Norman Daniels [...] constructs an argument based on prudential decisions from the perspective of an entire lifetime rather than a particular moment in time... in a way that improved our chances of attaining a normal life span" - p. 370) ${ }^{16}$.

A partir da $4^{a}$. edição, Callahan foi citado por sua perspectiva comunitária de que a sociedade deveria garantir assistência básica e decente a todos (mínimo existencial). O objetivo deveria ser que o idoso recebesse cuidados de forma a atingir de forma natural a duração completa de uma vida normal, após este ponto, apenas que tivesse o sofrimento aliviado em vez de receber procedimentos de extensão artificial da vida ("Daniel Callahan, takes a communitarian perspective [...] society should guarantee decent and basic care to all individuals, [...] goal should be to help the elderly live out a full and natural life span [...] When the natural life span has been reached [...], the goal should be to relieve their suffering rather than to claim life-extending care [...]' - p. $371)^{16}$. Isso foi mantido na $5^{a}$. edição (p. 261 $)^{69}$.

$\mathrm{Na} 4^{\mathrm{a}}$. edição, incluíram explicação de que tanto o sistema que privilegia o idoso quanto o que privilegia os mais jovens enfrentam problemas morais, políticos e práticos. Tais propostas poderiam facilmente perpetuar a injustiça, estereotipando o idoso por tratá-lo como bode expiatório pelos aumentos nos gastos em assistência de saúde e por criarem conflitos desnecessários entre gerações. Os idosos em cada uma das sucessivas gerações irão reclamar que 
não tiveram acesso às tecnologias desenvolvidas (frequentemente com o uso de recursos tributários) depois que já passaram por tais estágios de vida, e irão reclamar que seria injusto negar a eles estas tecnologias agora ("Both of these calls for age-based rationing face moral, political, and practical problems [...] Such proposals could easily perpetuate injustice by stereotyping the elderly, by treating them as scapegoats because of increases in health care costs, and by creating unnecessary conflicts between generations. Elderly persons in each succeeding generation will complain that they did not have access to new technologies that were developed (often using their taxes for funding) after they passed through their earlier years, and they will claim that it would be unfair to deny them those technologies now" - p. 371) ${ }^{16}$. Isso foi mantido na $5^{\mathrm{a}}$. edição (p. 261 $)^{69}$.

Continuam, na $4^{a}$. edição, iniciando os comentários sobre racionamento de tecnologias prolongadoras da vida, que não necessariamente significam economia, em parte, porque a simples assistência e suporte à manutenção da vida é cara e nem sempre pode ser facilmente diferenciada das terapias de prolongamento da vida ("Some critics contend that age-based rationing of lifeextending technologies would not save substantially on resources, in part because the provision of care, including long-term care and support services, is expensive and cannot always be sharply differentiated from the care that prolongs life" - p. 371 $)^{16}$. Tudo preservado na $5^{\text {a }}$. edição (p. 261-2) ${ }^{69}$.

$\mathrm{Na} 3^{a}$. edição, B\&C relatam que tem se questionado, na literatura recente, se o modelo preventivo, apesar de evitar doenças futuras dispendiosas, não faria aumentar o número de atendimentos na medida em que as pessoas viveriam mais (p. 288) ${ }^{17}$. Na $4^{\mathrm{a}}$., incrementaram afirmando que tudo o que é gasto nas comunidades pobres com prevenção, como assistência pré-natal, salva inúmeras vezes mais no futuro. $O$ que leva $B \& C$ a ter a "intuição moral" ("moral intuition") de que existirá um conflito entre alocar no imediato salvamento de vidas ou alocar para prevenir que mais pessoas venham a precisar disso ("[...] that every public health dollar targeted at poorer communities for preventive measures, such as prenatal care, saves many times that amount in future care. Accordingly, our moral intuitions often drive us in two 
conflicting directions: Allocate more to rescue persons in medical need and allocate more to prevent persons from falling into such need" - p. 364$)^{16}$. Tal qual na edição subsequente (p. 252) ${ }^{69}$.

A partir da $4^{a}$. edição, afirmaram que criar um sistema mais eficiente pelo corte de gastos e prover incentivos apropriados pode conflitar com 0 objetivo do acesso universal à assistência de saúde ("Creating a more efficient system by cutting costs and providing appropriate incentives can conflict with the goal of universal access to health care [... ' - p. 375) ${ }^{16}$ - passagem presente também na $5^{\mathrm{a}}$. edição (p. 262 $)^{69}$.

$\mathrm{Na} 4^{\mathrm{a}}$. edição, os autores incluíram afirmação de que, nas UTIs (Unidades de Tratamento Intensivo), o número de casos de pacientes muito graves admitidos e com admissão negada tendem a aumentar na medida em que os leitos nos hospitais são menos disponíveis. B\&C explicam que pesquisadores descobriram que a alocação dos leitos era mais influenciada por razões outras que a necessidade médica ou a severidade da doença, como o poder político (na instituição), o provincialismo médico (um serviço trocado por outro) e a maximização do critério renda na prestação de serviços de atendimento intensivo ("[...] in ICUs the number of cases of severely ill patients admitted and denied admission would increase as bed availability decreases [...] researchers discovered that bed allocation was decisively influenced by considerations other than medical suitability and severity of illness. According to the researchers, 'political power [in the institution], medical provincialism [one service pitted against another], and income maximization overrode medical suitability in the provision of critical care services" - p. 386$)^{16}$. Mantido na $5^{\text {a }}$. edição (p. 271-2) ${ }^{69}$.

Na $4^{a}$. edição, tal qual na $3^{a}$. (p. 301$)^{17}$, em sua conclusão, B\&C continuaram defendendo a posição de que não apenas uma teoria de justiça deveria ser adotada para o desenvolvimento de políticas de saúde ("[...] we have examined several philosophical approaches to justice [...] We have not maintained that a single theory of justice is essential for constructive reflection on health policy, and we have not argued for a single type of theory" - p. 386) ${ }^{16}$. 
Contudo, na $4^{a}$., acrescentaram que nossa sociedade deveria ser mais capaz de fechar lacunas de forma consciente no acesso à saúde do que foi no passado ("Our society may, however, be able to close gaps in access more conscientiously than we have in the past' - p. 387$)^{16}$. Por fim, passaram a defender que se deve adotar padrões de alocação utilitários e igualitários de acesso à saúde que garantam o mínimo existencial ("[...] by recognizing an enforceable right to a decent minimum of health care within a framework for allocation that coherently incorporates utilitarian and egalitarian standards" - p. $387)^{16}$. Partes preservadas na $5^{\text {a }}$. edição (p. 272) ${ }^{69}$.

\section{Alterações da $5^{\mathrm{a}}$. frente à $4^{\mathrm{a}}$. e à $6^{\mathrm{a}}$. edição}

$\mathrm{Na} 5^{\mathrm{a}}$. edição, os tópicos "The Concept of Justice" (O Conceito de Justiça), "Theories of Justice" (Teorias de Justiça), "Fair Opportunity" (Oportunidade Justa), "The Right to a Decent Minimum of Health Care" (O Direito a um Mínimo Decente em Saúde), "The Allocation of Health-Care Resources" (A Alocação de Recursos de Saúde) e "Rationing Scarce Treatments to Patients" (Racionando Tratamentos Escassos aos Pacientes) continuaram intactos. $\mathrm{Na} 5^{\mathrm{a}}$. edição, a única alteração foi no tópico "Rationing through Priorities in the Health Care Budget" (Racionando por meio de Prioridades no Plano de Assistência à Saúde), que passou a ser chamado de "Rationing and Setting Priorities" (Racionando e Estabelecendo Prioridades) ${ }^{69}$.

$\mathrm{Na} 5^{\mathrm{a}}$. edição, sobre as pesquisas terapêuticas, incluíram que a justiça, enquanto justo acesso à pesquisa (tanto participação quanto acesso aos resultados) se tornou tão importante quanto a proteção contra a exploração ("[...] therapeutic research and to the possible benefits of clinical trials (deemphasizing their risks). As a result, justice as fair access to research (both participation in research and access to the results of research) became as important as protection from exploitation" - p. 226-7 $)^{69}$. O que foi mantido na edição seguinte (p. 241 $)^{70}$. 
Apenas na $5^{a}$. edição, explicavam que vários princípios de justiça aparecem na moralidade comum e no reconhecimento do mérito. Esta é a única vez que a "moralidade comum" é referida no princípio da justiça ("[...] several principles of justice appear in the common morality and merit acceptance" - p. 227) ${ }^{69}$.

$\mathrm{Na} 5^{\mathrm{a}}$. edição, acrescentaram que há evidências de que a discriminação contra americanos afrodescendentes, outras minorias e mulheres frequentemente acontecem no momento da indicação a fazer transplantes e na admissão nas listas de espera ("Evidence suggests that discrimination against African Americans, other minorities, and women occurs at the point of referral to transplantation centers and admission to waiting lists [... " - p. 238 $)^{69}$. $\mathrm{Na} 6^{\mathrm{a}}$. edição, apenas trocaram afrodescendentes por "negros" ("blacks" - p. 251) ${ }^{70}$.

Exclusivamente na $5^{\mathrm{a}}$. edição, afirmavam que o direito à assistência de saúde pode ser geral ou específico, contrastando os direitos morais e legais específicos com um geral. Muitas sociedades reconhecem uma verdadeira "colcha de retalhos" ("patchworking") de direitos específicos e, por mais longe que isso possa se estender, não vai por si só equivaler a um direito geral de assistência à saúde ("A right to health care can be general or specific [...] we need to say why specific moral and legal rights to health care contrast sharply with a general right. Many societies recognize a "patchwork" of specific rights [...] A similar claim supports the provision of health care and compensation to subjects who were injured in research undertaken on behalf of society. However far such "patchworking" or "spot zoning" of rights extends, it will not by itself amount to a general right to health care" - p. 242) ${ }^{69}$.

$\mathrm{Na} 5^{\mathrm{a}}$. edição, acresceram Dworkin, que prega o uso de um teste hipotético de análise do que "seguradores prudentes ideais" ("ideal prudent insurers") escolheriam. Segundo B\&C, critica, com razão, o que define como uma utilização indevida do "princípio da salvação" ("rescue principle"), o qual sustenta ser intolerável, em uma sociedade, permitir que pessoas morram quando poderiam ter sido salvas por maiores gastos com em saúde. Argumentam que este princípio se desenvolve a partir de um "modelo de 
insuflação" ("insulation model"), que trata a assistência de saúde como diferente e superior a todos os outros bens, apelando à sua igual distribuição mesmo outros bens não sejam assim distribuídos. No entanto, este modelo ainda não consegue definir a maneira com que B\&C pretendem elencar os bens ("[...] Ronald Dworkin proposes in his hypothetical test of what "ideal prudent insurers" would choose under stated conditions. Dworkin rightly criticizes what he perceives as an undue use of the 'rescue principle'. This principle asserts that is intolerable for a society allows people to die who could have been saved by spending more money on health care. He argues that this principle grows out of an 'insulation model' that threats health care as different from and superior to all other goods and that calls for its equal distribution, even if society distributes no other goods equally [...]" - p. 246) ${ }^{69}$ - mantido na $6^{a}$. edição (p. 261 $)^{70}$.

Assim, no lugar deste modelo, Dworkin propõe que tentemos imaginar uma "seguridade prudente" ("prudent insurance"), prevendo assistência de saúde em um mercado livre e não subsidiado, sem todas as atuais deficiências. Este mercado ideal pressupõe uma distribuição justa de riqueza e de renda, informações plenas sobre benefícios, custos e riscos de vários procedimentos médicos, onde não seja levado em consideração probabilidade de morrer e onde qualquer montante que uma comunidade bem informada decida investir em assistência de saúde será justa, assim como o padrão de distribuição ("[...] Yet this model may not capture the way in which we do rank goods. In place of this model, Dworkin proposes that we try to imagine a "prudent insurance" ideal, which envisions health care under "a free and unsubsidized market", without all the deficiencies that currently characterize markets in health care. This ideal market presupposes a fair distribution of wealth and income, full information about the benefits, costs, and risks of various medical procedures, and ignorance about the likelihood that any particular person will experience morbidity, either life-threatening or non-life-threatening, from diseases and accidents. Under these circumstances, whatever aggregate amount a wellinformed community decides to spend on health care is just, as is the distribution pattern it chooses" - p. 246 $)^{69}$ - conservado na $6^{\text {a }}$. edição (p. 261 $)^{70}$. 
Unicamente na $5^{a}$. edição, citavam Williams, que defende que os jovens deveriam ter prioridade sobre os idosos nos tratamentos prolongadores de vida, porque estes já tiveram a oportunidade de viver mais anos e, por motivos de justiça (no sentido do que é justo), os jovens mereceriam viver estes anos também. $O$ autor defende uma equidade interetária, por meio do argumento da "justa duração" ("fair innings"), que prega que todas as pessoas teriam o direito de viver até o que chama de "duração normal" ("normal span"), e prega que aqueles que foram preteridos, de certa forma, foram trapaceados, enquanto que aqueles que viveram além viveram um tempo que não Ihes pertencia ("[...] the young should have priority for life-extending medical care because the old have had an opportunity to live more years and, on grounds of fairness, the young deserve chance to live those additional years. For instance, Alan Williams approaches intergenerational equity through a 'fair innings' argument. This argument builds on the intuition that everyone is entitled to some 'normal' span [...] and that those who fall short are somehow cheated, whereas those who get more live on "borrowed time" - p. 260-1) ${ }^{69}$.

$\mathrm{Na} 4^{\mathrm{a}}$. edição, ao falarem sobre a necessidade de se alterar o sistema de incentivos a médicos e consumidores-pacientes, defendiam que deveria apenas ser alterado (p. 375) ${ }^{16}$. Na $5^{\text {a., }}$ passaram a acastelar que um sistema de "incentivos aceitáveis" ("acceptable incentives") deveria ser desenvolvido ("[...] to develop acceptable incentives for physicians and consumer-patients" p. 262$)^{69}$, porém, excluíram a afirmação de que consumidores de assistência de saúde (em muitos casos, pagando por esta assistência) deveriam ser mais bem informados sobre os custos e alternativas do que têm sido, presente na anterior (p. 375 da $4^{\text {a }}$ ed. $)^{16}$. Desta forma, permaneceu na $6^{\text {a }}$. edição (p. 271 $)^{70}$.

$\mathrm{Na} 4^{\mathrm{a}}$. edição $(\text { p. } 355)^{16}$ e somente até a $5^{\mathrm{a}}$., afirmavam que o acesso à assistência de saúde poderia ter vários significados, algumas vezes, representando apenas que alguém não foi impedido de obtê-la. Nesse sentido, ter o direito de acesso não implica que outros devam prestar a assistência de saúde ou distribuí-la de forma equitativa. O sistema de acesso representa, em última instância, uma questão de liberdade de escolha e de responsabilidade financeira. Esta é a forma libertária de pensar, limitando-se direitos. Mais 
comum, no entanto, é esse direito de acesso se referir a um direito de obter bens e serviços específicos a que todos deveriam ter igual direito. Aqui, valores de igualdade e de solidariedade se destacam. Esta compreensão exige que todos tenham igualdade de acesso a todo tratamento disponível a todos ("Access to health care' has several meanings. Sometimes it means only that one is not legitimately prevented from obtaining health care. In this sense, having a right of access does not entail that others must provide health care or equitably distribute care. The system of access turns ultimately on freedom of choice and financial responsibility. Libertarians favor this interpretation and limit one's rights to this form of access. More commonly, however, a right of access to health care refers to a right to obtain specified goods and services to which every entitled person has an equal claim. Here values of equality and solidarity are prominent. Avery inclusive understanding of this right requires that everyone have equal access to every treatment that is available to anyone" - p. 244$)^{69}$.

$\mathrm{Na} 4^{\mathrm{a}}$. edição (p. 375) ${ }^{16}$, assim como na $5^{\mathrm{a}}$., explicaram que, apesar de justiça e utilidade parecerem valores opostos, ambos são indispensáveis no delineamento de um sistema de assistência de saúde. Criar um sistema mais eficiente pelo corte de custos e promovendo incentivos apropriados poderia conflitar com os objetivos de justiça de acesso universal à saúde, mas estes objetivos (assim como os baseados na autonomia de consentimento informado) podem fazer o sistema ineficiente ("Although justice and utility may appear to be opposed values, both are indispensable in shaping a health care system. Creating a more efficient system by cutting costs and providing appropriate incentives can conflict with the goal of universal access to health care, but justice-based goals of universal coverage (as well as autonomy-based goals of informed consent) also may make the system inefficient" - p. 262) ${ }^{69}$ - o que foi trasnposto para a conclusão na edição ulterior (p. 280 $)^{70}$.

$\mathrm{Na} 4^{\mathrm{a}}$. edição (p. 381) ${ }^{16}$ e somente até a $5^{\mathrm{a}}$., sustentavam que o contexto social é medicamente importante no sucesso final dos transplantes, particularmente no pós-operatório, podendo ter impacto na utilidade médica no sentido de eficiência e efetividade de uso de um órgão doado ("A network of support is often medically important in the overall success of the 
transplantation, particularly in post-transplant care, and it can have an impact on medical utility in the sense of an effective and efficient use of a donated organ" - p. 267)

Da mesma forma que na $4^{a}$. edição (p. 384-5) $)^{16}$, unicamente até a seguinte, afirmavam que reconhecem o mérito de todas as críticas ao critério do valor social. Contudo, B\&C entendem que, em casos raros e excepcionais, que envolvam pessoas de importância fundamental, ele deve prevalecer ("We acknowledge the merit of all the above criticisms of social worth criteria. However, we argue below that, in certain rare and exceptional cases involving persons of critical importance, criteria of social value are appropriately overriding" - p. 270) $)^{69}$.

$\mathrm{Na} 4^{\mathrm{a}}$. edição (p. 359) ${ }^{16}$ e exclusivamente até a $5^{\mathrm{a}}$., sobre a questão de se investigar as causas das doenças, para saber se uma pessoa deveria perder o direito à assistência de saúde por ter contraído doença por hábitos deletérios, havia afirmação de que, para se determinar com precisão as causas dessas doenças, deveria se ter amplos poderes de investigação, invadindo-se privacidade, quebrando-se confidencialidade e mantendo-se registros detalhados a fim de documentar tais abusos. Isso causaria pesados custos financeiros, além de ter características pouco atrativas do ponto de vista moral ("To determine accurately the causal conditions of particular health problems and to locate voluntary risk-takers officials would need broad investigative powers. In the worst-case scenario, these officials would invade privacy, break confidentiality, and keep detailed records in order to document health abuses that could result in a forfeiture of the right to a particular type of health care. Such enforcement would carry heavy financial costs in addition to its morally unattractive features" - p. 248) ${ }^{69}$.

$\mathrm{Na} 4^{a}$. (p. 359-60) edição ${ }^{16}$, continuando somente na quinta, explicavam que a maior razão para uma discussão sobre penalização no acesso à saúde é o aumento de custos. Contudo, prevenção de riscos por meio de mudanças de estilos de vida e de atitudes podem não levar a redução de gastos, eis que alguns hábitos de risco podem resultar em mortes prematuras, evitando que as 
pessoas vivam muito e desenvolvam debilidades crônicas ("A major reason for debate about forfeiture of rights to health care is raising costs, but prevention of risks through alterations in lifestyle and conduct often leads to counterintuitive outcomes. Some risk-taking involves less rather than more medical care, because it results in earlier and quicker deaths than might occur if individuals lived longer and developed chronic debilitating conditions" - p. 248) ${ }^{69}$.

Somente na $4^{\text {a }}$. edição (p. 366) $)^{16}$ e na quinta, falavam sobre os gastos em saúde nos Estados Unidos, dizendo que as pessoas que usam pouco os serviços acabam sendo obrigadas a consumir mais do que precisam, pagando por mensalidades que não gastam ("[...] When parties who are insured pay far less than the value of what they consume, they will consume more than they otherwise would" - p. 253-4) $)^{69}$.

A conclusão da $5^{\mathrm{a}}$. edição (p. 272$)^{69}$ é uma reescritura da contida na $4^{\mathrm{a}}$. (p. $386-7)^{16}$ e a da $6^{a}$. edição (p. 280-1 $)^{70}$, por sua vez, é uma reescritura daquela, apenas incluindo críticas sobre a necessidade de um sistema eficiente de financiamento e distribuição de assistência à saúde.

\section{Alterações da $6^{\mathrm{a}}$. frente à $5^{\mathrm{a}}$. e à $7^{\mathrm{a}}$. edição}

$\mathrm{Na} 6^{\mathrm{a}}$. edição, os tópicos "The Concept of Justice" (O Conceito de Justiça) e "Theories of Justice" (Teorias de Justiça) foram mantidos. O tópico "Fair Opportunity" (Oportunidade Justa) foi complementado: "Fair Opportunity and Unfair Discrimination" (Oportunidade Justa e Injusta Discriminação). Outros novos tópicos passaram a existir: "Vulnerability and Exploitation" (Vulnerabilidade e Exploração), "National Health Policy and the Right to Health Care" (Política Nacional de Saúde e o Direito à Assistência de Saúde), "Global Health Policy and the Right to Health" (Política Global de Saúde e o Direito à Saúde) e "Allocating, Setting Priorities, and Rationing" (Alocando, Estabelecendo Prioridades, e Racionando). Por fim, "The Right to a Decent Minimum of Health Care" (O Direito a um Mínimo Decente em Saúde), "The Allocation of Health-Care Resources" (A Alocação de Recursos de Saúde), 
"Rationing and Setting Priorities" (Racionando e Estabelecendo Prioridades) e "Rationing Scarce Treatments to Patients" (Racionando Tratamentos Escassos aos Pacientes) foram removidos ${ }^{70}$.

$\mathrm{Na} 6^{a}$. edição, começaram a usar a palavra "Bioética", até então não utilizada por B\&C. Fazem isso afirmando que, na literatura da Bioética, é sustentado que assistência à saúde é um bem especial e que suas necessidades são especiais para a teoria da justiça ("In bioethics literature it is widely held that health care is a special good and that needs for it are special needs for a theory of justice" - p. 242) ${ }^{70}$.

Apenas na $6^{a}$. edição, diziam que, em vários outros países, as primeiras barreiras da saúde e de sua assistência são a pobreza e os recursos estatais limitados. Os problemas de justiça são muito diferentes ao redor do mundo ("In many other countries the primary barriers to both health and health care are poverty and limited government resources. Problems of justice are very different in different parts of the world" - p. 258) ${ }^{70}$.

$\mathrm{Na} 6^{\mathrm{a}}$. edição, um item inteiro sobre vulnerabilidade e exploração foi incluído na obra de B\&C (p. 253-257) ${ }^{70}$. Abrem explicando que não se trata de um problema de distribuição de assistência à saúde, mas de problemas sobre a exploração da vulnerabilidade de sujeitos de pesquisa. B\&C anotam que se concentrarão no recrutamento e inscrição (especialmente nos ensaios farmacêuticos) dos economicamente desfavorecidos, normalmente desfavorecidos também na loteria social ("[...] These are not problems of health care distribution, but problems about the vulnerability of human research subjects at risk of exploitation. We concentrate on the recruitment and enrollment in clinical research (primarily pharmaceutical trials) of the economically disadvantaged, who are often disadvantaged by the social lottery" - p. 253) ${ }^{70}$. Passagem preservada na edição seguinte (p. 267 $)^{18}$.

Somente na $6^{a}$. edição, havia a definição de vulnerabilidade. Na Ética Biomédica, esta noção frequentemente foca na suscetibilidade da pessoa como resultado de fatores internos ou externos de incentivo ou coação, ou prejuízo, 
perda ou indignação por outros. Os economicamente desfavorecidos podem ser vulneráveis de várias maneiras, apresentando riscos significativos de dano diversos. Assim, eles não podem ser capazes de resistir ou recusar aceitação de riscos, exigindo balanceamento entre os seus interesses ("The concept of vulnerability. In biomedical ethics, the notion of vulnerability often focuses on a person's susceptibility, whether as a result of internal or external factors, to inducement or coercion, on the one hand, or to harm, loss, or indignity, on the other. The economically disadvantaged may be vulnerable in several ways to influences that introduce a significant risk of harm [...] Hence, they may not be able to resist or refuse acceptance of the risk involved, requiring trade-offs among their interests" - p. 254) $)^{70}$.

$\mathrm{Na} 6^{\mathrm{a}}$. edição, B\&C incluíram explicação de que, por "economicamente desfavorecido" ("economically disadvantaged"), deve-se entender pessoas pobres, o que também pode significar que não possuem acesso significativo à assistência de saúde, podendo ser sem-teto ou mesmo desnutridos, e assim por diante. Assim é possível não possuírem capacidade mental de se voluntariar em, por exemplo, pesquisas farmacêuticas inseguras e tóxicas de fase I. Porém, devem ser consideradas sempre como pessoas que possuem, ao menos, capacidade básica de razão, deliberação, decisão e de consentimento ("By 'economically disadvantaged', we mean persons who are impoverished, may lack significant access to health care, may be homeless, or may be malnourished, and so forth, and yet posses mental capacity to 'volunteer' in, for example, safety and toxicity (pahse I) drug studies. Thus, we are considering only persons who possess a basic competence to reason, deliberate, decide, and consent' - p. 253) ${ }^{70}$. Isso foi mantido na $7^{\mathrm{a}}$. edição ( $\mathrm{p}$. $267)^{18}$.

Unicamente na $6^{\mathrm{a}}$. edição, alegaram que não se deve afirmar que existe uma relação direta entre os economicamente desfavorecidos e a vulnerabilidade ou entre esta e a exploração por pesquisadores. As conexões são tênues e os conceitos complicados ("It should not be assumed that there is a straightforward connection between economically disadvantaged groups and 
vulnerability or between vulnerability and exploitation by researchers. The connections are subtle and the concepts complicated" - p. 253) ${ }^{70}$.

Apenas na $6^{\text {a }}$. edição, questionaram sobre a exclusão categórica dos economicamente desfavorecidos. Uma estratégia tentadora para proteger os interesses dessas pessoas seria exclui-las de plano, até mesmo se não forem vulneráveis. Esta medida eliminaria o problema da injusta exploração, mas seria prejudicial às suas liberdades de escolha e aos seus interesses econômicos, além de uma forma inescusável e paternalista de discriminação e de privação da justa oportunidade, que serviria apenas para marginalizar, excluir, estigmatizar ou discriminá-los ("Categorical exclusion of the economically disadvantaged? A tempting strategy to protect their interests is to exclude economically disadvantaged persons categorically, even if they are not categorically vulnerable. This remedy would eliminate the problem of unjust exploitation, but it would deprive them of the freedom to choose and would often be harmful to their financial interests [...], but to exclude them categorically would be an inexcusable, paternalistic form of discrimination and deprivation of fair opportunity that may only serve to further marginalize, deprive, stigmatize, or discriminate against them" - p. 254$)^{70}$.

A partir da $6^{a}$. edição, introduziram relato de que a noção de "grupo vulnerável" ("vulnerable group") foi significante à Bioética e às políticas de saúde entre os anos 1970 e 1990. Todavia, com o passar dos anos, sofreu uma sobreexpansão, porque muitos grupos agora foram declarados vulneráveis. O problema é que, para muitos grupos, um rótulo cobrindo todos os seus membros superprotege, estereotipa e até mesmo desqualifica os membros que são capazes de fazer suas próprias decisões. Vulnerabilidade é um rótulo inapropriado para qualquer classe de pessoas quando alguns membros da classe não são vulneráveis em seus aspectos relevantes. Assim, $B \& C$ esclarecem que não falam dos economicamente desfavorecidos como um grupo vulnerável, mas sim como uma das formas de vulnerabilidade. Idealmente, a Ética deve prover um esquema de formas e condições de vulnerabilidade em vez de dar uma lista de grupos vulneráveis ("The notion of a 'vulnerable group' was considered very significant in bioethics and health 
policy between the 1970s and the 1990s. However, over the years it suffered from overexpansion because so many groups have now been declared vulnerable... The problem is that for many groups a label covering all members of the group serves to overprotect, stereotype, and even disqualify members capable of making their own decisions. "Vulnerable" is an inappropriate label for any class of persons when some members of the class are not vulnerable in the relevant respects [...] Accordingly, we do not speak of the economically disadvantaged as a categorically vulnerable group. Instead, we speak of vulnerabilities. Ideally, research ethics can supply a schema of forms and conditions of vulnerability, rather than a list of vulnerable groups" - p. 253-4) $)^{70}$. Isso foi mantido na $7^{\mathrm{a}}$. edição (p. 267-8) ${ }^{18}$.

Excepcionalmente na $6^{a}$. edição, defendiam que algumas pessoas relatam se sentir pressionadas a se inscrever em ensaios clínicos, mesmo quando a inscrição se diz voluntária. Estas pessoas se encontram em desesperadora necessidade de dinheiro. Ofertas atrativas de dinheiro e outros bens deixam as pessoas com a sensação de não ter outra opção, senão aceitar. São pessoas que se sentem pressionadas por influências que muitas outras facilmente resistiriam ("Some persons report feeling heavily pressured to enroll in clinical trials, even though their enrollment is correctly classified as voluntary. These individuals are in desperate need of money. Attractive offers of money and other goods can leave a person with a sense of having no meaningful choice but to accept research participation. Such a person feels constrained by influences that many individuals easily resist" - p. 255) ${ }^{70}$. Assim, estas situações constrangem escolhas, mesmo quando não envolvem ameaças ("These situations significantly constrain choices, even though they do not involve threats" - p. 255) ${ }^{70}$.

Também acresceram, na $6^{a}$. edição, comentário sobre as remunerações dos sujeitos de pesquisa, explicando que elas se tornam cada vez mais problemáticas quando os riscos da pesquisa são maiores, elas se tornam mais atrativas e o número de sujeitos economicamente desavantajados aumenta. Uma remuneração irresistivelmente atrativa é condição necessária do "indevido induzimento" (“undue inducement”), situação que também deve envolver 
assumir um risco de sério dano, que não seria assumido em condições normais ("But inducements become increasingly problematic as (1) risks are increased, (2) more attractive inducements are introduced, and (3) the subjects' economic disadvantaged is increased" - p. 255-6) ${ }^{70}$. Isso foi sustentado na $7^{\mathrm{a}}$. edição ( $\mathrm{p}$. $269)^{18}$.

Somente na $6^{a}$. edição, existia comentário sobre as remunerações dos sujeitos de pesquisa, que, apesar destas ofertas não serem sempre coercitivas, porque nenhuma ameaça de excessivo risco ou de tirar dinheiro das pessoas está envolvida, podem, ao menos, ser manipulativas ("The presence of an irresistibly attractive offer is a necessary condition of 'undue inducement', [...] must also involve a person's assumption of a sufficiently serious risk of harm that he or she would not ordinarily assume [...] Although these offers are not coercive, because no threat of excessive risk or of taking money away from the person is involved, the offer can still be manipulative" - p. 256) ${ }^{70}$.

$\mathrm{Na} 6^{a}$. edição, adicionaram comentário sobre o indevido induzimento nas remunerações dos sujeitos de pesquisa, que deve ser diferenciado da "injusta remuneração" ("undue profits"), que ocorre quando o sujeito recebe um pagamento muito pequeno, injusto no sentido de haver distribuição desigual de benefícios, onde o sujeito de pesquisa recebe uma remuneração muito pequena se comparado ao fato de que quem promoveu a pesquisa recebeu mais do que o justificado ("Undue inducements should be distinguished from undue profits, which occur from a distributive injustice of too small a payment, rather than an irresistibly attractive, large payment. In the undue-profit situation, the subject of research receives an unfairly low payment, while the sponsor of research gets more than is justified [...] unjust share of the benefits [...]" - p. $256)^{70}$ - o que foi conservado na $7^{\mathrm{a}}$. edição (p. 269) ${ }^{18}$.

Excusivamente na $6^{a}$. edição, havia um item sobre o tema política global de saúde e direito à saúde, onde explicavam que o direito a um mínimo existencial na assistência de saúde é geralmente concebido em termos de política nacional de saúde, mas a ideia de um direito a um mínimo decente de saúde (embora as medidas de saúde pública de saneamento, abastecimento 
de água potável, e outras) poderia e deveria ser concebida como uma questão de ordem global, indo além dos sistemas nacionais de saúde. A globalização trouxe a percepção de que os problemas de proteção da saúde e manutenção de condições saudáveis são internacionais por natureza, assim, mudanças necessitarão de uma reestruturação da ordem mundial como um todo, baseada na justiça ("The right to a decent minimum of health care is typically conceived in terms of national health policy, but the idea of a right to a decent minimum of health (though public health measures, sanitation, supply of clean drinking water, and the like) can and should be conceived as a matter of the global order that reaches beyond national health systems. Globalization has brought a realization that problems of protecting health and maintaining healthy conditions are international in nature and that serious attempts at their alleviation will require a justice-based restructuring of the global order" - p. 264) $)^{70}$.

$\mathrm{Na} 6^{\mathrm{a}}$. edição, incluíram afirmação de que as teorias éticas e políticas que abordam explicitamente as questões de justiça global são hoje conhecidas como "teorias cosmopolitas" ("cosmopolitan theories"). B\&C explicam que tal abordagem os influenciou fortemente neste volume, tendo, como ponto de partida, condições sociais amplas e normalmente também catastróficas - em particular, fome, pobreza e epidemias ("Ethical and political theories that explicitly address questions of global justice are now widely referred to as 'cosmopolitan theories'. This approach, which has strongly influenced the authors of this volume, takes as its starting point large and usually catastrophic social conditions - in particular, famine, poverty, and epidemic disease" - $\mathrm{p}$. $264)^{70}$. Isso foi conservado na edição seguinte (p. 277) ${ }^{18}$.

Na 6a . edição, também passaram a citar Singer, o qual, fundamentado na beneficência utilitária, pauta seu trabalho nas obrigações dos agentes, pessoas e governos. Ao contrário, a perspectiva de justiça social igualitária (embasada em Rawls) que B\&C tomaram neste capítulo propõe que orientemos a teoria em torno da avaliação moral das instituições sociais e de suas responsabilidades, legitimidade e fraquezas. O foco não está sobre a moralidade das escolhas individuais, mas sobre a moralidade da estrutura básica da sociedade a partir de onde as escolhas morais são feitas ("Singer's 
theory, which is grounded in utilitarian beneficence, is oriented toward the obligations of agents such as persons and governments. By contrast, the perspective of egalitarian social justice that we often take (much like Rawls) in this chapter proposes that we orient theory around the moral evaluation of social institutions and their responsibilities, legitimacy, and weaknesses. The focus is not on the morality of individual choices, but on the morality of the basic structure of society from within which moral choices are made" - p. 265 $)^{70}$. Isso foi mantido na $7^{a}$. edição (p. 278) ${ }^{18}$.

$\mathrm{Na} 6^{\mathrm{a}}$. edição, trouxeram à baila Pogge, autor defensor da Teoria Cosmopolita, que argumenta que a tese de Rawls estaria limitada a nações e Estados, limitando-se indevidamente a aplicação da Teoria da Justiça. Uma teoria moral consistente aplicaria os princípios da justiça a qualquer situação ("Thomas Pogge, a prominent defender of cosmopolitan theory, argues that Rawls's thesis that the principles of justice are limited to specific nation-states unduly limits the theory of justice. A consistent moral theory will apply principles of justice everywhere" - p. 265 $)^{70}$. O que foi conservado na $7^{\mathrm{a}}$. edição (p. 278) ${ }^{18}$.

$\mathrm{Na} 6^{\mathrm{a}}$. edição, adicionaram afirmação de que um dos principais problemas de saúde internacional é o papel que a pobreza desempenha, causando e perpetuando a saúde pobre. Aqui, a grande preocupação é o direito à saúde, e não o direito à assistência de saúde. Assim, incluíram Powers e Faden na obra, os quais, na Bioética, construíram um quadro para a política internacional de saúde e de saúde pública com a premissa de que a justiça social se preocupa com o bem-estar humano, e não apenas com a saúde. Mencionaram o que chamam de seis dimensões fundamentais do bem-estar: saúde, segurança pessoal, racionalidade, respeito, afeição, e autodeterminação ("A major problem of international health is the role that poverty plays in causing and perpetuating poor health. Here it is the right to health, not the right to health care, that is the major concern. A framework for international health policy and public health has been constructed in bioethics by Madison Powers and Ruth Faden. They start with a basic premise about justice: 'Social justice is concerned with human well-being', not only health, but what they call six core dimensions of well-being: health, personal security, 
reasoning, respect, attachment, and self-determination" - p. 265) ${ }^{70}$. Isso mantido na $7^{\text {a }}$. edição (p. 260 e 265$)^{18}$.

Também incluíram, na $6^{a}$. edição, argumentos de que esta lista apresenta um conjunto útil de critérios para expressar os requisitos da justiça no âmbito da saúde pública e das políticas de saúde. Cada uma das seis dimensões é uma preocupação independente de justiça, e o papel da justiça é garantir um nível suficiente de cada dimensão para cada pessoa. A justiça das sociedades e da ordem mundial podem ser julgadas pela forma como se implementam essas dimensões ("They argue that the list presents a particularly useful set of criteria for expressing the requirements of justice within public health and health policy. Each of the six dimensions is an independent concern of justice, and the 'job of justice' is to secure a sufficient level of each dimension for each person. The justice of societies and of the global order can be judged by how well they implement these dimensions" - p. 265) ${ }^{70}$ - o que foi preservado na $7^{\mathrm{a}}$. edição (p. 260 e 265) ${ }^{18}$.

Apenas na $6^{a}$. edição, ainda citando Powers e Faden, esclareciam que apesar de apenas a primeira das seis dimensões do bem-estar ser a saúde, a justificativa moral para as políticas de saúde depende tanto as outras cinco dimensões fundamentais do bem-estar como da própria, pois a ausência de qualquer uma das outras condições poderia ser seriamente destrutiva a esta. Uma variedade de desigualdades poderia sistemicamente ampliar e reforçar as condições iniciais de baixa saúde, criando efeitos em cascata. Citam uma lista de efeitos interativos: pobre educação e falta de respeito, por exemplo, podem afetar as formas fundamentais de raciocínio e estado de saúde. As estruturas sociais podem ainda agravar estes efeitos adversos, o resultado é uma mistura de efeitos interativos e, em sequência, que exigem atenção urgente do ponto de vista da justiça ("Although only the first of the six dimensions of well-being in this account is health, Powers and Faden argue that the moral justification for health policies depends as much on the other five dimensions of well-being as it does on health. An absence of any of the other conditions can be seriously destructive to health. A constellation of inequalities can systemically magnify and reinforce initial conditions of ill health, creating ripple effects that attack 
various aspects of health. They are offering an account of interactive effects: Poor education and lack of respect, for example, can affect core forms of reasoning and health status. Social structures can compound these adverse effects. The result is a mixture of interactive and cascading effects that require urgent attention from the point of view of justice" - p. 265-6 $)^{70}$.

$\mathrm{Na} 6^{\mathrm{a}}$. edição, incluíram afirmação de que a Teoria Cosmopolita captura um aspecto crítico da justiça igualitária. A falta de saúde e as crescentes desigualdades são o resultado de muitos efeitos interativos. Seria absurdo, na teoria da justiça, tomar como único parâmetro, a distribuição de assistência de saúde, ignorando as muitas causas de baixa saúde e pouca distribuição de assistência. Privações de educação causam privações de saúde, assim como problemas de saúde podem tornar difícil a obtenção de uma boa educação. Qualquer uma das dimensões fundamentais do bem-estar de Powers e Faden poderia afetar o desenvolvimento das outras, e todas podem promover baixa saúde. Em algumas sociedades, há uma constante combinação de privações. Desigualdades nestas circunstâncias estão entre os mais urgentes que uma teoria da justiça deveria solucionar, independentemente do país em que ocorram ("Cosmopolitan theory captures a critical aspect of egalitarian justice. Poor health and growing inequalities are the result of many interactive effects. It would be absurd to look, in a theory of justice, only at the distribution of health care, ignoring the many causes of poor health and poor delivery of care. Deprivations of education cause deprivations of health, just as ill health can make it difficult to obtain a good education. Any one dimension of well-being can affect development of other dimensions of well-being, and all can make for poor health. In some societies, there is a constantly compounding body of deprivations. Inequalities in these circumstances are among the most urgent for a theory of justice to address, regardless of the nation in which they occur" - p. $266)^{70}$. Na $7^{\mathrm{a}}$., apenas trocaram "Teoria Cosmopolita" ("Cosmopolitan theory") por "Teoria Global" ("Global theory" - p. 278) ${ }^{18}$.

Também passaram a declarar, na $6^{\text {a }}$. edição, que as desigualdades não são meramente uma questão de má sorte ou de falhas pessoais. Elas são frequentemente distribuídas por instituições sociais que podem ser 
estruturadas explicitamente para reduzir as desigualdades. Se, por exemplo, as escolas públicas de nível mais baixo tiverem resultados educacionais lamentáveis, que, por sua vez, contribuem para a má alimentação e problemas de saúde, estaria em nosso poder reverter esta situação. Rawls estava certo ao apontar os efeitos importantes destas instituições, assim como seu lugar na teoria da justiça ("Inequalities are not merely a matter of bad luck or personal failings. They are often distributed by social institutions that can be structured explicitly to reduce the inequalities. If, for example, lower level public schools distribute woeful educational outcomes, which in turn contribute to poor diet and poor health, it is within our power to alter this situation. Rawls was certainly right to point to the pervasive effects of these institutions and their place in the theory of justice" - p. 266) ${ }^{70}$. O que foi mantido na $7^{\text {a }}$. edição (p. 279 $)^{18}$.

$\mathrm{Na} 6^{\mathrm{a}}$. edição, B\&C passaram a defender que tanto Pogge quanto Powers e Faden estavam certos ao falar que as desigualdades na saúde e bem-estar provocadas pela pobreza extrema têm urgência moral. Internacionalmente, uma das maiores desigualdades reside na expectativa de vida, pois em torno de vinte milhões de pessoas no mundo em desenvolvimento morrem por ano, incluindo milhões de crianças, por razões que vão desde desnutrição a doenças preveníveis ou tratadas de forma barata e fácil. Se a justiça social é global, esse tipo de desigualdade deveria estar no topo do a ser corrigido ("Both Pogge and Powers-Faden are right in arguing that inequalities in health and well-being brought about by severe poverty have a particular moral urgency. Internationally, the world is one of radical inequalities in almost every respect, most notably in life expectancies. Somewhere around twenty million people in the developing world die each year, including several million young children, from malnutrition and disease that can be inexpensively prevented or treated by cheap and available means. If the reach of social justice is global, this kind of inequality from disadvantaging conditions would be at the top of the conditions to be remedied" - p. 266) ${ }^{70}$. Tudo conservado na $7^{\text {a }}$. edição (p. 279) ${ }^{18}$.

A conclusão da $6^{a}$. edição é uma reescritura da presente na quinta edição (p. 272) ${ }^{69}$, apenas incluindo que países sem um sistema abrangente e 
coerente de financiamento e distribuição de assistência à saúde, tendo os Estados Unidos como exemplo, estão fadados a continuar no caminho de altos custos e grandes números de desprotegidos até que mudanças significativas ocorram. Deve-se melhorar tanto utilidade (eficiência) quanto justiça (enquanto o que é justo e equidade); apesar de parecerem valores opostos, ambas são indispensáveis no delineamento de um sistema de assistência de saúde. Claro, devendo haver trocas entre o que seria justo e eficiente ("Countries lacking a comprehensive and coherent system of health care financing and delivery - the United States being a prime example - are destined to continue on the trail of higher costs and larger numbers of unprotected citizens unless they make significant changes. They must improve both utility (efficiency) and justice (fairness and equality). Although justice and utility may appear to be opposing values, and have often been presented as such, both are indispensable in shaping a health care system [...] there must be trade-offs between equality and efficiency" - p. 280) ${ }^{70}$.

\section{Alterações da $7^{\mathrm{a}}$. frente à $6^{\mathrm{a}}$. edição}

$\mathrm{Na}$ última edição, pequenas alterações no capítulo sobre o Princípio da Justiça podem ser percebidas. Alguns tópicos tiveram seus nomes complementados, como: o "The Concept of Justice" (O Conceito de Justiça), que agora é o "The Concept of Justice and Principles of Justice" (O Conceito de Justiça e Princípios de Justiça); o "Theories of Justice" (Teorias de Justiça), que passou a ser "Traditional Theories of Justice" (Teorias Tradicionais de Justiça); e o "Vulnerability and Exploitation" (Vulnerabilidade e Exploração) foi transformado em "Vulnerability, Exploitation and Discrimination in Research" (Vulnerabilidade, Exploração e Discriminação na Pesquisa). Os tópicos "Fair Opportunity and Unfair Discrimination" (Oportunidade Justa e Injusta Discriminação), "National Health Policy and the Right to Health Care" (Política Nacional de Saúde e o Direito a Assistência de Saúde), "Global Health Policy and the Right to Health" (Política Global de Saúde e o Direito à Saúde) e "Allocating, Setting Priorities, and Rationing" (Alocando, Estabelecendo Prioridades, e Racionando) foram mantidos ${ }^{18}$. 
$\mathrm{Na} 7^{\mathrm{a}}$. edição, ao citarem princípios abstratos de justiça distributiva, alteraram a redação contida na anterior: de "para cada pessoa, distribuição igualitária" ("To each person an equal share" - p. 243) ${ }^{70}$ para "para cada pessoa de acordo com regras e ações que maximizam a utilidade social" ("To each person according to rules and actions that maximize social utility" - p. 253) ${ }^{18}$, de "para cada pessoa, de acordo com a necessidade" ("To each person according to need" - p. 243) $)^{70}$ para "para cada pessoa, o máximo de liberdade e propriedade como resultado do exercício de direitos de liberdade e participação nas trocas de livre mercado" ("To each person a maximum of liberty and property resulting from the exercise of liberty rights and participation in fair freemarket exchanges" - p. 253) ${ }^{18}$, de "para cada pessoa, de acordo com o esforço" ("To each person according to effort"- p. 243) ${ }^{70}$ para "para cada pessoa, de acordo com princípios de justa distribuição derivados das concepções de bem nas comunidades morais" ("To each person according to principles of fair distribution derived from conceptions of the good developed in moral communities" - p. 253) ${ }^{18}$, de "para cada pessoa, de acordo com a contribuição" ("To each person according to contribution" - p. 243) ${ }^{70}$ para "para cada pessoa, a medida igual de liberdade e de acesso aos bens da vida a que todas as pessoas racionais dão valor" ("To each person an equal measure of liberty and equal access to the goods in life that every rational person values" p. 253$)^{18}$, de "para cada pessoa, de acordo com o mérito" ("To each person according to merit" - p. 243) ${ }^{70}$ para "para cada pessoa, os meios necessários para o exercício de capacidades para uma vida radiante" ("To each person the means necessary for the exercise of capabilities essential for a flourishing life" p. 253$)^{18}$, de "para cada pessoa, de acordo com as trocas de livre mercado" ("To each person according to free-market exchanges" - p. 243) ${ }^{70}$ para "para cada pessoa, os meios necessários para a realização das dimensões fundamentais do bem-estar" ("To each person the means necessary for the realization of core dimensions of well-being" - p. 253) ${ }^{18}$.

$\mathrm{Na} 7^{\mathrm{a}}$. edição, tal qual já havia na $6^{\mathrm{a}}$. (p. 245) ${ }^{70}$, afirmam categoricamente que a saúde não é um direito e que o sistema ideal de assistência de saúde é o privatizado ("Health care is not a right under this 
conception, and privatization in the health care system is a protected value" - p. $256)^{18}$.

$\mathrm{Na} 7^{\mathrm{a}}$. edição, incluíram Taylor, segundo B\&C, o maior pensador da Teoria Comunitária, que contestou a tese de prioridade nos direitos individuais em detrimento do bem comum, defendendo que mesmo a autonomia baseada no individualismo não poderia ser desenvolvida na ausência de estruturas de família ou de outras relacionadas à comunidade ("Every major communitarian thinker has contested the thesis of the priority of individual rights over the common good [...] Even the type of autonomy suggested by individualism, Taylor argues, cannot be developed in the absence of the family and other community structures and interests" - p. 258) ${ }^{18}$.

$\mathrm{Na}$ última edição da obra, também houve a inclusão de citação de Callahan, outro autor comunitarista, que defende que se deveria proclamar políticas públicas a partir de um consenso comum sobre o "bem" na sociedade, mais do que sobre direitos individuais ("According to Daniel Callahan's communitarian account, we should enact public policy from a shared consensus about the good of society rather than on the basis of individual rights" - $\mathrm{p}$. $258)^{18}$.

Apenas na $7^{a}$. edição, adicionaram um item sobre as teorias recentes da justiça - o primeiro a apresentar uma conclusão como subitem (p. 262) ${ }^{18}$. Já no início, B\&C explicam que se dedicarão às teorias recentes que foram fortemente influenciadas por Aristóteles e Rawls e que são importantes e relevantes à Ética Biomédica ("This section is dedicated to recent theories that are heavily influenced by both Aristotle and Rawls and that are important and relevant for concerns in biomedical ethics" - p. 258-9) ${ }^{18}$.

A primeira a ser explicada é a Teoria das Capacidades, que parte do pressuposto de que a oportunidade para se atingir estados de funcionamento apropriado e bem-estar são de significância moral básica e que a liberdade para se atingir estes estados deveria ser analisada de acordo com a linguagem das capacidades. A qualidade das vidas das pessoas é dependente do que 
elas são capazes de conquistar. Citam Sen, como precursor da teoria, assim como Nussbaum, como defensora da teoria na Ética Biomédica, a qual estabelece o que seria "justiça social" ("social justice") e as "fronteiras da justiça" ("frontiers of justice"), incluindo temas como incapacitados, globalmente pobres e animais não humanos ("[...] capabilities theory starts from the premise that the opportunity to reach states of proper functioning and well-being are of basic moral significance and that the freedom to reach these states is to be analyzed in the language of 'capabilities'. The quality of persons' lives is contingent on what they are able to achieve [...] theory was pioneered by Amartya Sen and developed in numerous ways relevant to biomedical ethics by Martha Nussbaum, who uses the theory to address 'social justice' and the 'frontiers of justice' - the latter including justice for the disabled, the globally poor, and nonhuman animals" - p. 259 ${ }^{18}$.

A segunda é a Teoria do Bem-Estar, desenvolvida especialmente para a Bioética, Saúde Pública e Políticas de Saúde por Powers e Faden ("[...] concentrate on a different type of theory devised explicitly for bioethics, public health, and health policy by Madison Powers and Ruth Faden" - p. 260 ${ }^{18}$, onde B\&C voltam a citar as seis dimensões fundamentais do bem-estar, tal qual já faziam na edição anterior (p. 261 e 265) ${ }^{70}$.

No novo subitem de conclusão, explicam que as seis teorias apenas em parte trazem coerência e compreensão às fragmentadas e multifacetadas concepções de justiça social. Além disso, que o igual acesso, a livre escolha, a eficiência social e o bem-estar são todos objetivos justificados, mas que, porém, juntos, um anularia o outro ("We can expect the six theories we have now displayed to succeed only partially in bringing coherence and comprehensiveness to our multilayered and sometimes fragmented conceptions of social justice [...] equal access, free choice, social efficiency, and well-being are all justifiable in some domain [...] but they are also difficult to render coherent in a social system and in a theory of justice; pursuing one goal may function to undercut another" - p. 262) ${ }^{18}$. 
$B \& C$, ao final, explicam que, no entanto, muitos autores criticam estas teorias como tendo a mesma fraqueza que possuía o Estado ideal de Platão, em "A República", pois fornecem modelos, mas não instrumentos práticos ("Some commentators see these theories as having the weakness of Plato's ideal state in the Republic: They provide models, but not truly practical instruments" - p. 262 $)^{18}$.

Apenas na $7^{\text {a }}$. edição, declararam que uma teoria global aplica normas morais irrespectivamente de restrições políticas. A Teoria das Capacidades e a do Bem-Estar são explicitamente globais. O Comunitarismo e a Teoria Libertária são estatais, enquanto a Utilitária e muitas igualitárias podem sem locais ou globais ("[...] whereas a global theory applies moral norms irrespective of political boundaries. The capabilities theory and the well-being theory examined earlier are explicitly global. Communitarianism and libertarianism are statist theories. Utilitarian and many egalitarian theories could be fashioned as either global or local" - p. 276) ${ }^{18}$.

Finalmente, nesta mais recente edição, incluíram citação de Hume, que defende que todas as regras da justiça são inerentemente locais, apesar de as razões pelas quais a justiça ser necessitada nos Estados serem universais ("David Hume argued that all rules of justice are inherently local, even though the reasons why rules of justice are needed in states are universal" - p. 277) ${ }^{18}$.

A conclusão da $7^{\text {a }}$. edição $\left(\right.$ p. 292-3) ${ }^{18}$ é uma reescritura da presente na $6^{\mathrm{a}}$. edição (p. 280-1 $)^{70}$.

\subsubsection{Análise teórico-conceitual das alterações}

O princípio da justiça esteve presente em todas as sete edições da obra de B\&C. A maior crítica recebida em relação a ele foi a de que teria sido, de certa forma, desprestigiado no Principialismo, que sempre conferiu maior destaque ao princípio da autonomia. Certo que isso ocasionou mudanças na 
forma como B\&C o trabalharam, recebendo, aos poucos, maior atenção e destaque dos autores.

Da leitura do capítulo sobre este princípio, em especial da forma como foi realizada neste estudo, percebe-se que alguns referenciais, além dos comumente citados "equidade" (no sentido aristotélico de igualdade formal) e "alocação de recursos em saúde" (distribuição de recursos de saúde frente à escassez ou outra limitação material), se destacam pela constância nas edições. Sem, muitas vezes, separações nítidas dentro do capítulo, as categorias, mesmo assim e até mesmo por uma questão didática, foram aqui trabalhadas em apartado.

São elas: "moralidade comum", já aqui bem delineada; "Bioética", pois esta disciplina nem sempre foi referida na obra que foi considerada a "Bíblia" da Bioética; "saúde como um bem", eis que os autores não compreendem a saúde como um direito, mas sim como uma espécie de produto que deve ser comprado, de acordo com a "capacidade para pagar"; "mínimo existencial", que foi trabalhado pelos autores não enquanto um mínimo digno, mas enquanto definidor do que seria o a ser fornecido de saúde pelo Estado; "confidencialidade e privacidade" dos dados de pacientes, tema deixado em segundo plano por $B \& C$, que privilegiaram o princípio da autonomia neste ponto; "vulnerabilidade", "exploração" e "discriminação", os quais surgiram tardia e/ou minimamente na obra, talvez também pelo excesso de importância dada ao princípio da autonomia; "busca do bem-estar", trabalhada sob a ótica das seis dimensões de Powers e Faden; "seleção de pacientes" e o binômio necessidade terapêutica e custo de tratamento; "princípio da necessidade", que determina regras de distribuição de recursos segundo o princípio da necessidade; "pesquisa clínica", seus limites e a questão do recrutamento de sujeitos; "justa oportunidade" de acesso à saúde, segundo um princípio de justa igualdade de oportunidade; "justiça distributiva", como apropriada distribuição de ônus e bônus em um sistema de saúde; "prevenção", trabalhada na obra segundo critérios não de promoção de saúde, mas de economia; e, por fim, "teorias do princípio da justiça segundo B\&C", tendo em vista a exposição de algumas delas pelos autores. 
Por fim, destaco que as mudanças de algumas nomenclaturas utilizadas na obra refletem as mudanças que a própria acabou por sofrer, fazendo com que caminhasse no sentido de se tornar mais ética, respondendo às críticas sofridas e se tornando mais homogenea em relação à literatura internacional como um todo. Isso pode ser mais bem percebido nas duas últimas edições.

\section{Moralidade comum}

Apenas na $5^{a}$. edição, existia uma referência à moralidade comum dentro do capítulo do Princípio da Justiça. Nela, B\&C afirmavam que vários princípios de justiça existem na moralidade comum (p. 227) ${ }^{69}$.

\section{Bioética}

A palavra Bioética, apesar de já existir na obra em outras passagens, apareceu pela primeira vez no capítulo sobre o Princípio da Justiça já na $6^{a}$. edição $^{70}$. Na primeira menção, à p. 242, os autores afirmam que, na literatura bioética é amplamente aceito que assistência à saúde é um bem especial ${ }^{70}$. De fato, a Bioética trata de questões relacionadas à assistência de saúde, contudo, nem todas as bioéticas a tratam como um bem, mas, na maioria das vezes, como um direito - conforme será mais bem explicado adiante.

Ainda na $6^{\text {a }}$. edição (p. 253-4), assim como na $7^{\text {a }}$. (p. 267-8), relacionaram também a Bioética à noção de "grupo vulnerável", que, segundo B\&C, teria sido significante a ela entre os anos 1970 e $1990^{70}$. Ressalta-se que a inclusão de um item exclusivamente sobre a vulnerabilidade aconteceu nesta edição. Também nas duas últimas edições, foi citada ao tratarem do indevido induzimento (p. 255 e p. 268, respectivamente) e da Teoria do Bem-Estar de Powers e Faden (p. 265 e p. 260, na ordem) $)^{18,70}$. 


\section{Saúde como um bem e a capacidade para pagar}

$\mathrm{Na} 1^{\text {a }}$. edição, $\mathrm{B} \& \mathrm{C}$ se referiam à saúde como um bem de consumo a ser alocado primordialmente por decisões de cunho privado e mercadológico (p. 191 $)^{31}$. Explicavam que um dos mais intensos debates de justiça distributiva nos Estados Unidos foi sobre a seguridade de saúde nacional, eis que, historicamente, foi operada pelas leis de mercado, onde o princípio implícito de acesso é a capacidade para pagar, baseada em teorias libertárias de justiça ( $p$. 174-5) ${ }^{31}$.

Tal noção de saúde como um bem de consumo foi retirada na $2^{\mathrm{a}}$. edição, que passou a discutir a dificuldade de estabelecer o que seria "um direito" à assistência de saúde, o qual, obrigatoriamente, levaria a outros dois: igual acesso à assistência e direito à um mínimo existencial (p. 203-4) ${ }^{68}$. Direitos estes defendidos, mesmo que não devidamente cumpridos, por países periféricos, onde o ideal de beneficência é mais exacerbado ${ }^{23}$. Mesmo assim, a partir da $2^{\mathrm{a}}$. edição, desenvolveram melhor a ideia da capacidade para pagar como princípio de mercado da teoria libertária de justiça, tendo, como principal filósofo, Nozick (p. 190 da $2^{a}$. e p. 255 da $7^{a}$. edição ${ }^{18,68}$. Nesta $2^{a}$. edição já explicavam que o princípio da capacidade para pagar, de cunho libertário, se concentra nos direitos individuais das pessoas, onde cada um escolhe o quanto quer contribuir e, por causa e de acordo com isso, recebem seus ônus e bônus (p. 190 $)^{68}$. Assim, as novas descobertas são destinadas a quem "pode" comprar e não mais a quem "precisa" ${ }^{24}$, negando-se acesso a novas tecnologias aos mais pobres ${ }^{24}$.

Nessa busca pelo estabelecimento do que seria um direito à assistência de saúde, da $3^{a}$. à última edição, explicaram que estas necessidades são determinadas por tudo aquilo que seria necessário para conquistar, restaurar ou manter adequados níveis de "funcionamento típico das espécies" (p. 269-70 da $3^{a}$. e p. 257 da $7^{a}$. edição) ${ }^{16,70}$. Ainda na $3^{a}$., mas agora somente até a $5^{a}$. edição, complementavam dizendo que isso não significa que todo e qualquer cuidado deveria ser provido pela sociedade, mas simplesmente que nenhuma pessoa deveria ser impedida de obter "acesso" à assistência de saúde (p. 278- 
9 da $3^{a}$. e p. 244 da $5^{a}$. edição $)^{16,69}$. Tão somente "acesso", e não "assistência" efetiva.

Contudo, apesar de, à primeira vista, parecer que B\&C tratam a saúde como um direito, desde a $1^{\text {a }}$. edição (189-190) ${ }^{31}$, para eles, a saúde é, na verdade, um "bem" social ${ }^{31}$. A partir da $3^{a}$. edição, tal qual haviam expressado apenas na $1^{\text {a }}$. edição, deixam claro também que a "assistência à saúde" é muito mais uma questão privada, devendo ser regida pelas leis de mercado e segundo critérios de quem possui capacidade para pagar por ela (p. 276) $)^{17}$. Isso se explica pelo fato de B\&C adotarem declaradamente não apenas a concepção de justiça de Rawls, mas também a noção contratualista rawlsiana de distribuição de bens, onde saúde, alimentos e o que seria, para a maioria das nações, direitos fundamentais, são tidos como "bens" (e não direitos) a serem "dados" segundo critérios de justa distribuição ou "comprados" por quem pode pagar (e não com o significado de uma conquista social) ${ }^{22}$.

Esta posição vai de encontro ao que se buscou defender por meio da Bioética de Intervenção, de cunho utilitarista e consequencialista, mas solidária e que não olha para quem busca favorecer, tratando, dessa forma, os mais pobres da mesma forma que os mais ricos, os únicos que poderiam realmente pagar, desde que o maior bem ao maior número de pessoas possa ser alcançado $^{23}$.

$\mathrm{Na} 4^{\mathrm{a}}$. edição, B\&C chegaram a afirmar que a assistência à saúde não representaria um direito. Nesse sentido, o que defendem é a privatização do sistema de saúde, eis que, segundo os autores, existem valores a serem protegidos, como o direito de propriedade e de liberdade (p. 336) $)^{16}$, se esquecendo dos demais direitos que buscam a proteção da integridade das pessoas $^{23}$.

Ocorre que, se tomarmos a saúde como um direito propriamente dito (como grande parte do mundo ocidental sustenta, inclusive a América Latina), este seria uma mescla de obrigação perfeita e imperfeita, pois exige tanto deveres positivos (perfeita), quando se diz que o Estado deve prover sua 
assistência, quanto negativos (imperfeita), quando se afirma que a autonomia dos sujeitos não deve ser ferida ${ }^{79}$. No final das contas, como plano de fundo, B\&C buscam não o provimento efetivo de direitos negativos e positivos, como deveria ser, mas apenas saber se o Estado deve provê-los e em qual nível.

$\mathrm{Na} 3^{\mathrm{a}}$. edição, e apenas nela, B\&C assumem expressamente que a saúde seja um "bem primário" (p. 269) ${ }^{17}$. Curioso é que trazem à obra o autor Daniels justamente nesta edição, o qual possui o entendimento de que a saúde não deveria ser incorporada ao rol de bens primários, pois, caso fosse, outros diversos bens também deveriam, desvirtuando a noção de bens essenciais ${ }^{79}$. Foi assim que, a partir desta edição, B\&C passaram a discutir o que chamam de sistema de distribuição de assistência à saúde da "dupla amarração" (p. $279)^{17}$. Nele, duas vertentes estariam presentes, uma com um mínimo nível de bens socialmente alocados, e, outra, com um segundo nível de bens conquistados por iniciativa individual (p. 269) ${ }^{17}$. Em outras palavras, um sistema de saúde onde há um serviço público básico e outro paralelo privado para quem deseja um atendimento mais personalizado e pode pagar por isso. Assim, a defesa deste sistema por B\&C explica o porquê de defenderem que se deveria estabelecer o que seria um direito à assistência de saúde, já que, somente o que pertencesse ao seu rol deveria ser provido pelo nível mínimo a ser garantido a todos.

Nesta mesma $3^{\text {a }}$. edição, e apenas nela, citam Engelhardt ao dizer que não existe direito humano básico à distribuição de saúde, nem mesmo a um mínimo existencial. Para este autor, então, os princípios da beneficência e da autonomia embasam o "sistema da dupla amarração" de assistência à saúde (p. 278) $)^{17}$ - do que B\&C não discordam (p. 278) ${ }^{17}$, já que o direito à saúde, na visão deles só deveria ser cumprido no âmbito público e tão somente no nível mais primário.

Apenas nesta $3^{a}$. edição também afirmaram que seria simplesmente um infortúnio, e não uma injustiça, uma pessoa não poder pagar por assistência à saúde. Segundo B\&C, do ponto de vista mercadológico, todos os preços são justos e nenhum injusto, pois o estabelecimento deles é feito pelo próprio 
mercado (p. 267) ${ }^{17}$. Em outras palavras, para B\&C, se um preço elevado é determinado dentro de um sistema de trocas, onde aqueles que adquirem os produtos (pagando por eles) e aceitam as condições de aquisição são os mesmos que atuam nessa determinação, não podendo, portanto, depois reclamar das consequências, ou seja, dos preços altos que aceitaram e acabaram por convalidar.

Olhando sob este prisma, se poderia pensar que a posição defendida por B\&C seria também uma forma de tratamento utilitarista das pessoas, sem olhar para quem seria provido, ou não, o efetivo direito à saúde. Contudo, não se pode esquecer a verdadeira intenção da Bioética de Intervenção, a qual busca a proteção dos mais necessitados, não permitindo que se deixe entregue à sorte aquelas menos favorecidos pela loteria social ${ }^{23}$. Hoje, tal qual a distribuição dos recursos financeiros costuma se dar de forma desigual entre os diferentes países, ou entre seus próprios habitantes, o acesso à saúde também se apresenta díspar, porém, diretamente proporcional à capacidade econômica de cada $\mathrm{um}^{24}$. Trata-se de uma proteção exacerbada de direitos de cunho libertário em detrimento do acesso igualitário aos mais necessitados. Isso porque a garantia de assistência de saúde igual a todos teria como consequência necessária o detrimento da liberdade de consumidores e prestadores de serviço, na mesma medida em que a aceitação de assistência deficitária aos mais necessitados excluiria qualquer ideal de assistência igualitária $^{79}$.

Em todas as edições, B\&C afirmam que as pessoas ficarão desapontadas ao perceber que o padrão de assistência básica a ser fornecida pela vertente pública é decente, e não excelente - sendo surreal esperar que vá além do apenas adequado (p. 175 da $1^{\text {a }}$. e p. 257 da última edição) ${ }^{18,31}$.

Reduzindo ainda mais o conceito de assistência pública de saúde, a partir da $3^{a}$. edição passaram a defender que este direito de acesso não implica que deva ser efetivamente prestada, ou mesmo distribuída de forma equitativa, pois o sistema de acesso como um todo representa, em última instância, uma questão de liberdade de escolha e de responsabilidade financeira de cada um. 
Chegam a reconhecer que esperar direito a efetivos tratamentos seria utópico (p. 259-60 da $3^{\text {a }}$. e p. 272 da $7^{\text {a }}$. edição) ${ }^{18,70}$. Trata-se, portanto, não apenas de uma forma de pensamento libertário, mas também limitador de direitos que há muito são considerados fundamentais por diversas nações calcadas em valores de igualdade e de solidariedade ${ }^{58}$ e não em de liberdade e autonomia, como o que B\&C defendem.

Foi assim que, apenas a partir da $3^{\mathrm{a}}$. edição criticam o "Plano de Reforma da Saúde de Oregon", o qual favoreceu inúmeros tratamentos relativamente pequenos em detrimento de outros maiores potencialmente salvadores de vida (p. 285-6) ${ }^{17}$. B\&C embasaram esta crítica em seu Princípio da Justiça, por sua vez, calcado na Teoria de Rawls, onde princípio da diferença permite desigualdades apenas na medida em possam igualar a situação de grupos menos privilegiados à de mais beneficiados, e nunca o oposto $^{22}$, tal qual sustenta a visão utilitarista da Bioética de Intervenção ${ }^{23}$.

$\mathrm{Na} 6^{\text {a }}$. edição, novamente, afirmam que a literatura bioética esteia que assistência à saúde é um "bem", mas agora especial, e que as necessidades dela são necessidades especiais para a teoria da justiça (p. 242 ${ }^{70}$. Por fim, nas três últimas edições, nada mudou neste sentido, continuando os autores a defender que a saúde não é um direito e que seu sistema ideal de assistência é o privatizado (p. 232, p. 245 e p. 256 , na ordem) ${ }^{18,69,70}$. Porém, nas duas últimas edições, reconhecem que outras privações, como a de acesso à informação, causam carências de saúde, assim como o contrário também seria verdadeiro, já que saúde precária também dificulta o acesso à educação. Nestas edições, B\&C dizem que seria absurdo ignorar as várias outras causas de saúde precária e de pouca distribuição de assistência (p. 266 e p. 278, respectivamente $)^{18,70}$. Trata-se de uma tentativa dos autores do Principialismo de demonstrar ter uma visão mais holística do problema, já iniciada na $4^{a}$. edição com as questões sanitárias e ampliada nas duas últimas. Contudo, B\&C não conseguiram desenvolver a questão além do incluir a Teoria do Bem-estar de Powers e Faden à obra. 


\section{Mínimo existencial}

Na $1^{a}$. edição, B\&C introduziram a noção de "mínimo decente" de Fried (p. 175) - mais conhecida no Brasil pelo nome de "mínimo existencial" (nomenclatura aqui adotada) $)^{31,79}$. Nesta edição, assim como nas seguintes, referem a necessidade de se definir o que seria ou, ao menos, o que ela conteria (p. 175) ${ }^{31}$ pois somente assim, poder-se-ia estabelecer o que a assistência à saúde básica deveria garantir ao menos.

A partir da $2^{\mathrm{a}}$. edição a questão passou a ser trabalhada por meio de exemplos, com, primeiramente, o dos transplantes, destacados na obra pelo alto custo (p. 202-3) ${ }^{68}$. Já na $3^{a}$. edição discutem se estes tratamentos fariam parte do mínimo existencial ou se seriam complementares, citando a "Força Tarefa em Transplantes de Órgãos", que se baseou na continuidade deles, tomando como premissa que fariam parte sim do mínimo existencial ou, ao menos, do nível adequado de saúde que a sociedade é obrigada a prover a todos (p. 286) $)^{17}$.

$\mathrm{Na} 4^{\text {a }}$. edição isso não foi diferente, acrescentando o caso dos idosos, onde $B \& C$ defendem que deveriam receber cuidados de forma a atingir a duração completa de uma vida natural, após este ponto, apenas devendo ter o sofrimento aliviado - nunca receber procedimentos de extensão artificial da vida (p. 371) ${ }^{16}$. Como se pode perceber, o constante incremento do uso de exemplos por B\&C é uma característica da obra como um todo, em especial, quando não conseguem conceituar ou fundamentar seu ponto de vista.

O que se percebe, na realidade, é que a busca por um conceito de mínimo existencial, na obra de B\&C, foi sempre voltada a se descobrir em que deveria consistir o mínimo a ser provido em assistência à saúde por uma sociedade, tratando-se mais de uma questão de quanto deveria se gastar do que seria correto prover. Oliva, contudo, ao tentar conceituar mínimo existencial, nos mesmos parâmetros de Fried, explica que se trata de um direito positivo de obtenção de bens quando houver repartição dentro de padrões de escassez. Para ele, o critério de diferenciação entre desejos e 
necessidades se encontra na integridade física e moral das pessoas, as quais se preservam pela posse de certos bens básicos, como educação e assistência de saúde (p. 5) $)^{79}$.

Como se pode notar, estabelecer o que é ou em que consiste o mínimo existencial não é um problema exclusivo de B\&C, pois tampouco outros autores já conseguiram. Nesse sentido, esta crítica voltada à obra de B\&C, na verdade, reflete um problema geral, ainda sem solução.

O que se critica aqui, na verdade, não é a incapacidade de B\&C definirem o que ninguém conseguiu, mas sim a forma como tentaram fazer isso. A real questão de fundo sempre residiu, para estes autores, não na garantia de direitos básicos das pessoas, mas sim na busca de não despender recursos estatais demasiadamente com os mais carentes, os quais são, por sua vez, os que menos contribuem e os que costumam mais necessitar de assistência.

Na 4. edição B\&C chegaram a introduzir a noção de "bem comum" ( $p$. 337-8), como um ponto básico de referência para a deliberação pública sobre como estabelecer o mínimo existencial (p. 356-7) ${ }^{16}$, outro conceito introduzido na obra sem maiores resultados práticos à solução de conflitos. Entre outros, este foi um dos aspectos criticados por Clouser e Gert, ainda em 1990, ou seja, logo após a publicação da $3^{\mathrm{a}}$. edição da obra, quando já registravam a maneira como o princípio da justiça era trabalhado no Principialismo, pois consistiria em uma diretriz impossível de ser seguida ${ }^{6}$, representando tão somente um conjunto de exemplos discutidos sem qualquer comando de aplicação prática.

Ainda nessa busca, já na $5^{a}$. edição, B\&C associam o mínimo existencial a escolhas prudentes, as quais determinariam o que um sistema universal de saúde deveria assegurar a todos. Desta vez, os próprios autores acabaram reconhecendo que esta proposta envolveria embates entre reivindicações de utilidade social e de bem comum, aclamando questões muito complexas para uma única teoria ética resolver (p. 246-7) ${ }^{69}$. 
Apesar do que possa parecer à primeira vista, este é apenas mais um instituto apresentado na obra como um exemplo, não se tratando de nenhum ponto de inflexão, pois a preocupação com os direitos universalmente protegidos continuou ausente. Para Clouser e Gert, o problema é outro, já que a visão igualitária de $\mathrm{B} \& \mathrm{C}$, prima facie obriga as pessoas a tratarem seus semelhantes de forma igual, sem explicar como ou mesmo igual em a quế.

Mudando um pouco o foco, apenas na $6^{\mathrm{a}}$. edição trouxeram o exemplo da globalização, com a percepção de que os problemas de proteção da saúde e manutenção de condições saudáveis deveriam ser internacionais por natureza ${ }^{70}$. Passaram a falar de políticas globais de saúde, onde explicam que a ideia de direito a um mínimo existencial de saúde poderia e deveria ser concebida como uma questão de ordem global, indo além dos sistemas nacionais (p. 264) ${ }^{70}$.

\section{Confidencialidade e privacidade}

Desde a $1^{\mathrm{a}}$. edição (p. 178-9) B\&C trataram da questão da privacidade em sua obra, relacionando-a ao princípio do respeito pela autonomia - já que constitui uma de suas várias regras ${ }^{31}$. Este foi, entretanto, o princípio que mais se contrapôs ao da justiça e, não foi em vão, que a privacidade acabou trabalhada segundo critérios de autonomia, seguindo o que representa uma constante na obra: o individual sufocando o coletivo ${ }^{12}$.

Já na $3^{a}$. edição, adicionaram a regra da confidencialidade à privacidade (p. 282 $)^{17}$. A partir de então, estes dois temas foram tratados em conjunto na obra até a $5^{\mathrm{a}}$. edição, sendo excluídos da $6^{\mathrm{a}}$. em diante, o que vai de encontro ao que a comunidade internacional de as nações, por meio da Unesco, passou a defender a partir de 2005, com a Declaração Universal sobre Bioética e Direitos Humanos, a qual possui a privacidade e a confidencialidade como princípios centrais ${ }^{58}$. 


\section{Vulnerabilidade, discriminação, exploração e busca do bem-estar}

$\mathrm{Na} 6^{a}$. edição B\&C incluíram um novo item exclusivo sobre a vulnerabilidade, o "Vulnerability and Exploitation" (Vulnerabilidade e Exploração), o qual foi alterado, na última edição, para "Vulnerability, Exploitation and Discrimination in Research" (Vulnerabilidade, Exploração e Discriminação na Pesquisa $)^{70}$, onde, como se pode perceber, o tema da vulnerabilidade foi tratado pelos autores em conjunto com o da exploração, além do da discriminação. A referida edição, além de ser a primeira a tratar com mais afinco do tema da vulnerabilidade, foi a única a apresentar um tópico só sobre ela, além de incluir seu conceito, este, como algo focado na susceptibilidade da pessoa, como resultado de fatores internos ou externos de incentivo ou coação, ou para prejudicar, fazer perder ou indignar a pessoa ( $p$. $254)^{70}$.

$\mathrm{Na} 6^{\mathrm{a}}$. e na $7^{\mathrm{a}}$. edições, como aqui já salientado, introduzem e relacionaram a noção de "grupo vulnerável" à Bioética. Ao mesmo tempo, criticam que os grupos vulneráveis sofreram uma sobre-expansão, já que hoje existem vários assim declarados (p. 253-4 e 267-8, na ordem) ${ }^{18,70}$. Esta qualificação, ao mesmo tempo em que clama por necessidades particulares, representa um rótulo, que superprotege, estereotipa e até mesmo desqualifica seus membros, os quais, muitas vezes, são capazes de fazer escolhas autônomas (p. 253-4 e 267-8, na ordem) ${ }^{18,70}$. Da mesma forma, esse excesso no número de tipos de grupos acaba por desvirtuar o sentido de assim declarálos, já que, se todos são especiais, realmente especial acaba por ser nenhum.

Apesar de toda essa inovação na $6^{a}$. edição, alguns exemplos sobre vulnerabilidade e exploração já existiam nas edições anteriores. Desde a $2^{\mathrm{a}}$., perdurando até a $4^{\mathrm{a}}$., defendiam a necessidade de educação especial para pessoas com deficiência mental (p. 197-8 na $2^{a}$. e p. 342 na $4^{a}$. edição) ${ }^{16,68}$. Contudo, apenas na $2^{a}$. edição falavam sobre a diferença de custos, pois este tipo de serviço sairia mais caro, devendo ser financiado pelo Estado, mas sempre se limitando à quantidade de recursos destinada à educação (p. 271) ${ }^{68}$. 
$\mathrm{Na} 3^{\mathrm{a}}$. edição defendem que, se as pessoas não são responsáveis por seu processo de envelhecimento, seria injusto alocar assistência prioritária a jovens antes de idosos (p. 272) ${ }^{17}$. A partir da $4^{a}$. edição até a última explicam que tanto o sistema que privilegia o idoso quanto o que privilegia os mais jovens enfrentam problemas morais, políticos e práticos (p. 371 e p. 286, respectivamente, na $4^{a}$. e $7^{a}$. edição) $)^{16,18}$. Tais propostas poderiam facilmente perpetuar a injustiça, estereotipando o idoso por tratá-lo como bode expiatório por causa de seus aumentos nos gastos em assistência de saúde e por criar conflitos desnecessários entre gerações (p. 371 e p. 286, respectivamente, na $4^{\mathrm{a}}$. e $7^{\mathrm{a}}$. edição) $)^{16,18}$.

Da $4^{\mathrm{a}}$. à $7^{\mathrm{a}}$. edição, falam sobre a discriminação de negros e mulheres no acesso à saúde, em especial, por questões econômicas. Até mesmo o uso da tipagem do antígeno linfocitário humano, que, à primeira vista, seria um critério objetivo, moral e medicamente justificável, tem sido usado como forma de discriminar, pois determina a prioridade nas listas à maioria dos doadores, que é branca (p. 346 da $4^{a}$. e p. 266 da $7^{a}$. edição) ${ }^{16,18}$.

A partir da $4^{a}$. edição e até a $6^{a}$. também falam da discriminação que existe por fatores não atribuíveis a diferenças biológicas, onde homens e mulheres que são tratados de maneira diferente por razões que parecem não relacionadas às suas condições médicas (p. 347 e p. 252, respectivamente, das edições mencionadas) ${ }^{16,18}$. Porém, apenas na $4^{a}$. e na $5^{a}$. edição, $B \& C$ relataram que estudos demonstram que as mulheres vão mais vezes ao médico e realizam mais procedimentos por visita do que os homens, contudo, disparidades de acesso a tratamentos entre os gêneros persistem em três áreas: câncer de pulmão, doença cardíaca e transplantes de rim (p. 3473 p. 239, na ordem) $)^{16,69}$.

A partir da $4^{a}$. até a $7^{a}$. edição levantaram evidências de que a discriminação contra norteamericanos afrodescendentes, mulheres e outras minorias frequentemente acontecem no momento da indicação e da admissão nas listas de espera para fazer transplantes (p. 346 e p. 266, correspondendo à $4^{a}$. e $7^{a}$. edição $)^{16,18}$. Contudo, apenas na $4^{a}$. e na $5^{a}$. edição, alertavam sobre a 
suspeita de que as minorias estariam servindo como doadores potenciais de órgãos, o que, consequentemente, fez com que as doações nestes grupos se tornasse escassa (p. 346-7 e p. 239$)^{16,69}$.

$\mathrm{Na} 6^{\mathrm{a}}$. e na $7^{\mathrm{a}}$. edição levantam a questão do tema da exploração de sujeitos de pesquisas, explicando não se tratar de um problema de distribuição de assistência à saúde, mas sim de exploração da vulnerabilidade (p. 253 e p. $267)^{18,70}$.

$\mathrm{Na} 5^{\mathrm{a}}$. e na $6^{\mathrm{a}}$. edição apenas, defendiam que a justiça enquanto justo acesso à pesquisa (tanto participação quanto acesso aos resultados) se tornou tão importante quanto a proteção contra a exploração (p. 226-7 e p. 241 $)^{69,70}$.

No que tange à pobreza, apenas na $6^{\text {a }}$. edição afirmaram que um dos principais problemas de saúde internacional é o seu papel ao causar e perpetuar a saúde precária. Nesta edição, B\&C parecem querer demonstrar que passaram a se preocupar mais com a questão do direito à saúde do que com a da assistência de saúde, onde trazem à baila a teoria de Powers e Faden, sobre o bem-estar humano (em suas seis dimensões) e sua influência na saúde (p. 265) ${ }^{70}$.

Foi assim que, a partir da $6^{\text {a }}$. edição, trouxeram à obra Powers e Faden, que, na Bioética, construíram um quadro para a política internacional de saúde e de saúde pública com a premissa de que a justiça social se preocupa com o bem-estar humano, e não apenas com a saúde, por meio do que chamam de seis dimensões fundamentais do bem-estar (p. 265 da 6a . e p. 260 da $7^{\text {a }}$. edição $)^{18,70}$. Nas duas últimas edições, B\&C explicam que esta lista apresenta um conjunto útil de critérios para expressar os requisitos da justiça no âmbito da política internacional de saúde e de saúde pública. Cada uma das seis dimensões representa uma preocupação independente de justiça (p. 265 da $6^{\text {a }}$. e p. 261 da $7^{a}$. edição) $)^{18,70}$. Para Powers e Faden, o papel da justiça é garantir um nível suficiente de cada dimensão para cada pessoa. A justiça das sociedades e da ordem mundial podem ser julgadas pela forma como se implementam essas dimensões, as quais, de forma interligada possibilitam a 
implementação da saúde dos indivíduos (p. 265 da $6^{a}$. e p. 261 da $7^{\text {a }}$. edição) $)^{18,70}$.

Nas duas últimas edições, por fim, esclarecem que, apesar de apenas a primeira das seis dimensões do bem-estar ser a saúde, a justificativa moral para as políticas de saúde dependem tanto das outras cinco dimensões quanto da própria saúde (p. 265-6 da 6 ${ }^{\text {a }}$. e p. 261 da $7^{\text {a }}$. edição) ${ }^{18,70}$. Assim, a ausência de qualquer uma das dimensões poderia ser seriamente destrutiva para a saúde. Trata-se, portanto, de uma inter-relação onde as desigualdades podem sistematicamente se ampliar e reforçar as condições iniciais de baixa saúde, criando efeitos em cascata que afetam vários aspectos da saúde como um todo (p. 265-6 da 6 $6^{\text {a }}$ e p. 261 da $7^{\text {a }}$. edição) $)^{18,70}$.

\section{Equidade, justa oportunidade e justiça distributiva}

Apenas na $1^{\mathrm{a}}$. edição, ao falarem sobre o princípio da justiça formal, ou da igualdade formal, ou mesmo da equidade, o explicam conceituando: "a equidade existe quando indivíduos que são iguais nos seus aspectos relevantes são tratados igualmente, enquanto indivíduos que são desiguais nos aspectos relevantes são tratados de forma diferente, mas na proporção de suas diferenças" (p. 171-2) ${ }^{31}$. Esta foi a única edição a trazer este conceito.

Curioso notar que, exclusivamente na $2^{\mathrm{a}}$. edição, apesar de terem retirado o conceito de equidade da obra (presente só na $1^{\text {a }}$. edição - p. 171$172)^{31}$, incluíram e explicaram o que seria a "iniquidade", como sendo as disparidades das garantias que deveriam assegurar o valor igual de todas as pessoas (p.184-5) ${ }^{68}$.

Já a menção a questões de justiça distributiva esteve presente na edição inaugural da obra de B\&C (p. 169) ${ }^{31}$. Porém, foi, na $2^{\text {a }}$. que os autores, ao tratarem do tema, esclareceram que seria uma apropriada distribuição de "ônus" e "bônus" e explicaram do que seria composta: uma série de princípios e regras morais, legais e culturais. Tais normas são chamadas de "termos de 
cooperação de uma sociedade", ou seja, cláusulas implícitas que obrigam os indivíduos a cooperarem mutuamente (p. 184) ${ }^{68}$.

Assim, B\&C definem justiça distributiva em termos de obrigações e direitos e do que ela contém. Trata-se de uma característica constante da obra, como já foi dito, omitir definições e tentar explicar conceitos por meio de exemplos. Porém, a justiça distributiva vai além do que B\&C apresentam, pois, em regra, representa uma maneira de distribuir de forma justa bens essenciais em uma sociedade, segundo a equidade aristotélica, ou mesmo segundo regras de oferta e demanda do mercado ${ }^{79}$.

Da $4^{\mathrm{a}}$. à $7^{\mathrm{a}}$. edição, modificaram o conceito de justiça distributiva para o de justa, equitativa e apropriada distribuição determinada por normas justificadas que estruturam os termos da cooperação social. Além disso, incluíram temas sobre benefícios e obrigações como propriedade, recursos, tributação, privilégios e oportunidades (p. 327 da $4^{\text {a }}$. e p. 250 da $7^{\text {a }}$. edição) ${ }^{16,18}$.

$\mathrm{Na} 1^{\mathrm{a}}$. e na $2^{\mathrm{a}}$. edição explicaram que, em situações de escassez, a igualdade deveria ser entendida como "igualdade de oportunidade" porque nem todos os iguais conseguem ser tratados de maneira igual (p. 194-5 e p. $214)^{31,68}$. Na $3^{a}$. edição já começam a falar em "justa" distribuição de assistência à saúde, baseada em um princípio de "justa igualdade de oportunidade" (p. 269-70) ${ }^{17}$. Tratam-se dos primeiros comentários sobre a regra da justa oportunidade, onde, se uma pessoa não é responsável pela desvantagem que apresenta na sociedade, não deve ser privada de auferir benefícios por este motivo (p. 186) ${ }^{31}$. Um corolário do que B\&C chamam de teoria causal das origens das vantagens e desvantagens (p. 184-6) ${ }^{31}$.

$\mathrm{Na} 2^{\mathrm{a}}$. edição, passaram a discutir alguns exemplos, como o dos fumantes e dos alcoolistas, que poderiam ser responsáveis, ou não, pelas doenças resultantes de seus hábitos deletérios/condutas de risco, o que, como consequência, poderia acarretar a perda do direito à assistência de saúde pública (p. 198) ${ }^{68}$. Na $3^{\mathrm{a}}$. edição, enfocando novamente comportamentos deletérios/condutas de risco, questionaram também se deveria ser coberta pela 
assistência à saúde casos como de AIDS (p. 280-1) ${ }^{17}$. Da mesma forma, trataram a questão dos idosos, pois, se as pessoas não são as responsáveis por seu processo de envelhecimento, não seria justo alocar assistência prioritária a jovens em detrimento dos idosos (p. 272) ${ }^{17}$.

Já na $3^{\text {a }}$. edição, perdurando até a última, em consonância com o que passaram a defender em todo o capítulo da justiça, argumentaram a favor de uma seleção social-utilitária (apesar de mais controversa do que a médicoutilitária), pois as instituições de saúde e o seu pessoal são garantias da sociedade e, portanto, deveriam considerar as futuras possíveis contribuições dos pacientes (p. 299 da $3^{\text {a }}$. e p. 271 da $7^{\text {a }}$. edição $)^{17,18}$. Essa talvez seja mais uma das várias respostas dadas por $B \& C$ às críticas recebidas. Desde as críticas ao Principialismo iniciadas nos anos 1990, temas como vulnerabilidade e a própria comercialização da saúde, passaram a exigir um olhar bioético que fosse além dos quatro princípios de $B \& C^{23}$.

Nesse contexto, no âmbito da Bioética latinoamericana, a Bioética Dura ou Bioética de Intervenção, priorizou políticas públicas e tomadas de decisão que, de maneira utilitarista, privilegiavam o maior número de pessoas e durante o maior espaço de tempo, buscando sempre as melhores consequências ainda que coexistindo prejuízos proporcionalmente menores ${ }^{24}$.

Como exemplo de paradigma utilitarista, tem-se somente na $3^{\mathrm{a}}$. e na $4^{\mathrm{a}}$. edição, citação de Rescher, que prega que, se uma sociedade investe um recurso escasso em uma pessoa em detrimento de outra, deveria buscar o retorno deste investimento (p. 299 da $3^{\text {a }}$. e p. 384-5 da $4^{a}$. edição) ${ }^{16,17}$. O que demonstra que B\&C adotam, ao contrário do que a Bioética latinoamericana prega como fim, não buscando as melhores consequências para o maior número de pessoas, mas sim a busca do melhor custo-benefício ${ }^{24}$.

Apesar disso, não se deve esquecer que, apenas na $2^{a}$. edição, defendiam que a igualdade deveria ser tida sob critérios de igualdade de oportunidade, já que nem todos conseguem ser tratados da forma (equitativa) que mereciam; assim como que seria necessário determinar se "realmente" os 
candidatos para o tratamento escasso tiveram, ou não, a justa oportunidade de entrar na fila a tempo (p. 214) ${ }^{68}$. Diante da dificuldade de se determinar como seriam estas avaliações, B\&C retiraram essa passagem da obra ${ }^{17}$.

Também não se deve olvidar que, B\&C, apesar de terem defendido o uso de critérios objetivos de maneira crescente ao longo da obra, apenas na $4^{a}$. e na $5^{a}$. edição também reconheciam que o critério subjetivo social deveria ser eleito em casos raros e excepcionais que envolvam pessoas de importância fundamental, chegando a afirmar que determinadas pessoas, como autoridades e políticos, deveriam ter prioridade pelo papel que possuem na sociedade (p. 384-5 da $4^{\text {a }}$. e p. 270 da $5^{\text {a }}$. edição) ${ }^{16,69}$. Argumento difícil de justificar, motivo pelo qual foi retirado da obra.

Sobre a questão dos idosos, apenas na $5^{\mathrm{a}}$. edição citaram Willians, que defende que os jovens deveriam ter prioridade sobre os idosos nos tratamentos prolongadores de vida, porque estes já tiveram a oportunidade de viver por mais anos e, por motivos de justiça, os jovens mereceriam viver estes anos também (p. 260-1) ${ }^{69}$. Este autor, citado apenas na $5^{\text {a }}$. edição, defende uma equidade inter-etária, por meio do argumento da "justa duração", onde todas as pessoas teriam o direito de viver até o que chama de "normal duração" da vida. Assim, aqueles que foram preteridos, de certa forma, foram trapaceados, enquanto que aqueles que viveram além, para o autor utilizaram tempo de vida emprestado (p. 260-1) $)^{69}$.

Assim, percebe-se que, desde a $1^{\text {a }}$. edição, B\&C defendem uma discriminação positiva no que tange a tratamentos diferentes para pessoas também diferentes (p. 171-2) ${ }^{31}$. Contudo, apenas a partir da $2^{a}$. é que tomam o cuidado de diferenciar o setor público, pois nele, dentro de grupos de pares atendidos por programas de assistência social, como os de pobres e de idosos, por exemplo, as pessoas devem ser atendidas de forma igual - sob pena de se estar promovendo novas injustiças (p. 187) ${ }^{69}$.

No que tange à justiça distributiva, destaca-se que, na $7^{\text {a }}$. edição nova redação é dada a alguns de seus princípios abstratos, trocando a "distribuição 
igualitária" (p. 243) pela "maximização da utilidade social" (p. 253); a "necessidade" (p. 243) pela "liberdade e propriedade nas trocas de livre mercado" (p. 253); o "esforço" (p. 243) pela "justa distribuição de acordo com a concepção de bem" (p. 253); a "contribuição" (p. 243) pela "liberdade de acesso" (p. 253); o "mérito" (p. 243) pelos "meios necessários para uma vida boa" (p. 253); e as "trocas de livre mercado" (p. 243) pelos "meios necessários para a realização das dimensões fundamentais do bem-estar" (p. 253) ${ }^{18}$.

Como se pode perceber, cada um dos princípios alterados reflete novos institutos que B\&C foram incluindo ao longo da obra, como, por exemplo, o detrimento da necessidade em prol da capacidade para pagar e da justa distribuição e as trocas de livre mercado de acordo com critérios que valorizam a noção de bem-estar de Powers e Faden.

Novamente, a questão de fundo que permeia a discussão travada por B\&C se concentra não na garantia de direitos, mas sim na melhor relação custo-benefício, chegando ao ponto de defender a perda do direito de acesso à saúde por aqueles que mais necessitam, muitas vezes por questões de escolhas que nem mesmo são autônomas.

Outra constante na obra, o debate de exemplos sem apresentação de qualquer solução prática, também está aqui presente. A efetiva intervenção na ética prática, tal qual prevê a Bioética de Intervenção, em momento algum é apresentada por B\&C, os quais se mantêm brandos, política e concretamente inativos $^{63}$.

\section{Seleção de pacientes e alocação de recursos}

Desde a $1^{\text {a }}$. edição, B\&C discutem a posição de os provedores de saúde fazerem as decisões de alocação baseados no valor social das pessoas ( $p$. $197)^{31}$, onde apenas as decisões de urgência e necessidade médica não envolveriam tais valores (p. 197) ${ }^{31}$. 
Foi assim que, já na $1^{\text {a }}$. edição o mérito de quem iria receber os tratamentos de saúde era discutido. Nela, por meio da "teoria causal das origens das vantagens e desvantagens", os autores já debatiam o que deveria ser levado em conta na justa distribuição de recursos (p. 186) ${ }^{31}$. A real questão cingia-se a saber se pessoas que assumem hábitos deletérios voluntários (ou condutas de risco, como chamam a partir da $2^{\mathrm{a}}$. edição - p. 207-8) $)^{31,68}$ poderiam ter direito a tratamentos de saúde custeados por toda a sociedade ( $p$. $191)^{31}$.

Por trás disso, discutia-se o fato de que a saúde é custeada, muitas vezes, por segurados que nem se utilizam do sistema de saúde (p. 274) ${ }^{31}$. Como exemplo, na $2^{\mathrm{a}}$. edição, defendem o uso do valor social do prognóstico de sucesso no tratamento (p. 215) ${ }^{68}$. Sobre este valor, apenas na $3^{a}$ e na $4^{a}$. edição $B \& C$ citaram Rescher, que defendia que, se a sociedade investe um recurso escasso em uma pessoa, em detrimento de outra, deveria respeitar um prognóstico de retorno de seu investimento (p. 299 da $3^{\mathrm{a}}$. e p. 384-5 da $4^{\mathrm{a}}$. edição) $)^{16,17}$.

Isso pode ser percebido quando, na $3^{a}$. edição defenderam que o aspecto familiar (critério subjetivo) pode indicar o valor que a pessoa representa para os outros, o que também pode ser medicamente relevante (critério objetivo) no sucesso pós-operatório de um transplante. Além disso, que a utilidade médica, consubstanciada na eficiência e na eficácia no uso de um órgão que fora doado (critérios objetivos), seria respeitada (p. 295-6) ${ }^{17}$.

Nesta 3a. edição B\&C iniciaram a diferenciação entre alocação (destinação de recursos escassos de forma maleável) e racionamento (destinação de recursos escassos de maneira mais dura) (p. 290), o que não foi em vão ${ }^{17}$. A partir da $4^{\text {a }}$. edição explicam a origem militar da palavra racionamento, que era usada apenas com conotação de dividir porções entre soldados (p. 365) ${ }^{16}$ - sentido utilizado pelos autores ao longo das demais edições para se referir à alocação de recursos em saúde em geral. 
O embate entre utilidade e igualdade, também foi inaugurado na $3^{\text {a }}$. edição, a partido do questionamento se tratamentos com transplantes fariam parte do mínimo existencial (p. 286) $)^{17}$. Mais uma vez, B\&C tecem considerações sobre tratamentos que tem como pano de fundo, não a definição de um mínimo existencial em saúde, mas sim a preocupação com gastos excessivos em saúde. Prova dessa preocupação, é que, a partir da mesma $3^{\text {a }}$. edição $B \& C$ defendem que $O$ acesso aos tratamentos com implantes ou transplantes de coração, tratamentos dos mais caros em saúde, apenas deveriam ser concedidos a pessoas sem condições financeiras de custeá-los e que não fossem cobertas pelos planos de assistência médica estadunidense, o Medicare (assistência de alto custo financiada pela seguridade social) e o Medicaid (assistência de baixo custo financiada pelo governo federal) - $p$. $286^{17}$.

Nesse ínterim, apenas na $3^{\mathrm{a}}$. e na $4^{\mathrm{a}}$. edição ilustram que muitas propostas para melhorar este sistema (Medicare/Medicaid) foram baseadas não na justiça, mas nas virtudes da caridade, da compaixão e da benevolência pelas pessoas doentes (p. 276-7 da $3^{\text {a }}$. e p. 349-50 da $4^{\text {a }}$. edição) ${ }^{16,17}$. Contudo, para B\&C, na era da alta tecnologia e dos altos custos, estes ideais se mostraram inadequados à tarefa de lidar com muitas necessidades médicas. Para eles, os antigos modelos de assistência voluntária, gradualmente, deram vez a um modelo amplamente aceito de um obrigatório direito a assistência de saúde baseada na justiça (p. 276-7 da $3^{\text {a }}$. e p. 349-50 da $4^{\text {a }}$. edição) ${ }^{16,17}$. Isso se coaduna com o que Garrafa \& Prado e Oliva defendem, que o uso da justiça como embasamento do direito à saúde como uma constante de ordem mundial. Contudo, Garrafa \& Prado se baseiam no fato de uma mudança de perspectiva a partir do cumprimento de direitos (insculpidos em declarações internacionais), e não na incapacidade da justiça de lidar com questões de ordem financeira ${ }^{55,79}$.

$\mathrm{Na} 3^{\mathrm{a}}$. edição, o que permaneceu até a última, B\&C falam sobre o "Força Tarefa em Transplantes de Órgãos", onde defendem que não seria justo, sendo até mesmo explorador, solicitar às pessoas que doem órgãos, se depois serão distribuídos de acordo com a capacidade de pagar o procedimento de 
transplante (p. 287 da $3^{\text {a }}$. e p. 373-4 da $7^{\text {a }}$. edição) ${ }^{17,18}$. Assim, ao longo de toda a obra, com ênfase na $3^{a}$. edição, a noção de alocação de recursos para B\&C se resume a evitar gastos com procedimentos caros, em especial, com aquelas pessoas que poderiam pagar por eles e com os que causaram sua própria doença.

Interessante é que unicamente na $2^{\mathrm{a}}$. edição expuseram que as pessoas em geral consideram fumantes, alcoolistas e obesos como pessoas nãoautônomas (p. 207) ${ }^{68}$. Ora, se estas pessoas são apontadas nas edições seguintes como grandes consumidores de assistência à saúde, torná-los autônomos seria o mesmo que excluir-lhes o direito de acesso - o que B\&C defendem.

$\mathrm{Na} 3^{\mathrm{a}}$. edição também ampliaram os exemplos, incluindo doenças, como a AIDS, o câncer de pulmão e as disfunções de fígado (p. 280-1 $)^{17}$. Fato curioso foi terem incluído, também como exemplo, as "livres trocas de mercado" (p. 261) ${ }^{17}$ - fator nem mesmo relacionável a uma pessoa.

Apenas nesta $3^{a}$. edição, esclareciam que o uso da idade poderia não ser apenas um critério social, mas um indicativo de probabilidade de sobrevivência, o que seria relevante em uma cirurgia maior (p. 295 $)^{17}$. Assim, categoricamente, B\&C encontram uma maneira de afastar outro grupo que costuma despender gastos (o dos idosos) do direito de assistência à saúde.

Diante desse emaranhado de ideias, na $3^{a}$. edição, $B \& C$ reconheceram ser não "difícil" (como acreditavam na $2^{\mathrm{a}}$. ) $^{68}$, mas "impossível", apontar as responsabilidades individuais por cada necessidade médica, onde a complexidade das doenças, as limitações do conhecimento, as predisposições genéticas, as condições sociais e de meio ambiente também estariam envolvidas (p. 282) ${ }^{17}$.

Segundo Oliva, contudo, esta forma de selecionar os merecedores de assistência à saúde não está de acordo com o próprio autor que fundamentou o princípio da justiça de B\&C (Rawls), já que pode-se afirmar que praticamente 
todos os processos de saúde-doença são atribuíveis a infortúnios naturais ou sociais, o que exige que as instituições sociais atuem com equidade. Somente assim, repondo estas pessoas a uma situação de justa igualdade de oportunidades, elas poderão, finalmente, ter um desenvolvimento pleno ${ }^{22,79}$.

Isso tudo, ao contrário do que possa parecer à primeira vista, uma preocupação de $B \& C$ com a saúde dos indivíduos, não passa de mais uma demonstração de ansiedade com os recursos financeiros da sociedade despendidos na saúde - isso em um país (Estados Unidos) onde justamente o fator determinante na alocação de recursos não se limita à escassez.

Tudo isso fica claro ainda na $2^{\mathrm{a}}$. edição, onde $\mathrm{B} \& C$ defendem que não seria paternalista proteger os recursos financeiros da sociedade, por exemplo, tributando as pessoas que assumem estilos de vida arriscados (como alcoolistas e fumantes), para cobrir seus maiores gastos em saúde (p. 208) ${ }^{68}$. $\mathrm{Na} 3^{\mathrm{a}}$. edição chegaram a pregar o pagamento de seguros específicos para estas pessoas (p. 283) ${ }^{17}$.

Tais posições tornam o direito de assistência à saúde mero objeto de compra e venda em um livre mercado. Assim, B\&C, por trás de uma discussão sobre alocação de recursos públicos de saúde, tentam desconstruir qualquer ideal distributivo solidário de distribuição de recursos ${ }^{24}$. É o que se apreende quando defendem que quem gasta mais deveria pagar mais, onde, na verdade, não se estaria distribuindo nada, mas sim vendendo algo que se precisa apenas àquelas pessoas que podem pagar por isso.

Outra demonstração clara de preocupação com a questão financeira reside no fato de iniciarem, ainda na $2^{\text {a }}$. edição, a defesa de que estilos de vida arriscados podem, na realidade, requerer menores cuidados de saúde porque as pessoas morreriam mais cedo e mais rápido ${ }^{68}$. B\&C chegam a declarar que uma análise ampla de custo-benefício desprestigiaria políticas de saúde interventivas nestes grupos de risco (p. 208) ${ }^{68}$. 
Em consonância, nas edições posteriores à $3^{a}$., excluíram passagens que falavam que a sociedade deveria proteger a relação médico-paciente da noção de investimento econômico - pois o médico tem a tarefa de cuidar do paciente, não sendo o responsável por políticas públicas já que sua primeira obrigação é apenas o paciente (p. 213) ${ }^{17}$.

Além disso, a partir da $3^{a}$. edição retratam a expectativa de que a sociedade tem de receber, como retorno decente de seus tributos pagos, assistência à saúde adequada, eis que pagam pela formação de médicos e pelo financiamento de pesquisas biomédicas. Isso porque existe mais investimentos na pesquisa e treinamento de assistência à saúde do que nesta propriamente dita (p. 276-7) $)^{17}$.

Assim, B\&C defendem, da $3^{\mathrm{a}}$. até a $5^{\mathrm{a}}$. edição, que "oportunidade" e "ordem de chegada" são critérios baseados na justiça, uma vez que asseguram justa igualdade de oportunidade. Ao mesmo tempo, relatam terem sido criticados por utilizarem mecanismos impessoais, o que consistiria uma irresponsável maneira de se fugir de uma decisão, além de fazer com que os primeiros previnam os que mais necessitam (p. 298 da $3^{\mathrm{a}}$. e p. 268-9 da $5^{\mathrm{a}}$. edição) ${ }^{17,69}$.

Apesar de defenderem concomitantemente o uso de critérios objetivos de maneira crescente na obra, não conseguem se livrar das críticas. Por isso, apenas na $4^{\mathrm{a}}$. e na $5^{\mathrm{a}}$. edição, $B \& C$ reconhecem que o critério subjetivo social deveria ser eleito em casos raros e excepcionais que envolvam pessoas de importância fundamental (p. 384-5 da $4^{a}$. e p. 270 da $5^{\text {a }}$. edição) ${ }^{16,69}$. Apenas nestas edições, apoiaram que pessoas, como autoridades e políticos, deveriam ter prioridade pelo papel que possuem na sociedade, mais um argumento difícil de justificar e que foi simplesmente excluído da obra nas edições subsequentes $^{16,69}$.

Apenas na $4^{\mathrm{a}}$. e na $5^{\mathrm{a}}$. edição, afirmavam que às pessoas com saúde frágil, doenças preexistentes ou histórico familiar de doenças que sugerem maiores gastos futuros com saúde, frequentemente, é negada cobertura, 
oferecido menos cobertura ou é cobrado mais caro por planos de saúde ( $p$. 348-9 da $4^{\text {a }}$. e p. 240 da $5^{a}$. edição) ${ }^{16,69}$.

Contudo, apenas na mesma $4^{a}$. edição, explicam que o sistema de seguridade americano é injusto porque se baseia nos empregadores; assim, os de médio e grande porte podem proporcionar melhores coberturas, até mesmo porque o governo oferece subsídios. Pessoas com empregadores pequenos frequentemente não são asseguradas e, por causa das cláusulas excluidoras, acabam existindo pessoas que, a despeito de serem seguradas, são menos seguradas ou ocasionalmente seguradas (p. 349 $)^{16}$.

Explicavam também, apenas na $4^{\mathrm{a}}$. edição, que os hospitais, mesmo com tantas regulamentações tentando prevenir abusos, vão continuar achando formas de negar atendimento a indigentes, pois estas regulamentações apenas vão de encontro aos efeitos visíveis do sistema de saúde, não atingindo as camadas mais profundas do problema, o que irá continuar até que haja forte incentivo financeiro e que até que exista um sistema de seguridade adequado e acesso equitativo (p. 350$)^{16}$.

Assim que, apenas na $3^{a}$. edição citam Nozick ao defender o Estado mínimo, ou "Estado vigilante noturno", onde as ações governamentais seriam justificadas apenas se protegessem os direitos e as garantias dos cidadãos, propondo uma teoria de justiça que afirmasse direitos não de maneira coercitiva, mas de forma a criar modelos de distribuição econômica como os encontrados no socialismo e no capitalismo impuro, redistribuindo as riquezas por meio do livre mercado, como, por exemplo, na tributação progressiva dos mais afortunados (p. 268) ${ }^{17}$.

Da $4^{a}$. até a $7^{a}$. edição, explicam que, apesar de justiça e utilidade parecerem valores opostos, ambos são indispensáveis no delineamento de um sistema de assistência de saúde. Criar um sistema mais eficiente pelo corte de custos e promovendo incentivos apropriados poderia conflitar com os objetivos de justiça de acesso universal à saúde, mas estes objetivos (assim como os 
baseados na autonomia de consentimento informado) podem fazer o sistema ineficiente (p. 375 da $4^{\text {a }}$. e p. 281 da $7^{\text {a }}$. edição $)^{16,18}$.

Como forma de solução deste impasse, da $5^{\mathrm{a}}$. à $7^{\mathrm{a}}$. edição, $\mathrm{B} \& \mathrm{C}$ citam Dworkin, que prega o uso de um teste hipotético de análise do que "seguradores prudentes ideais" escolheriam sob certas condições. Segundo B\&C, Dworkin critica, com razão, o que define como uma utilização indevida do "princípio da salvação", onde seria intolerável, em uma sociedade, permitir que as pessoas morram, quando poderiam ter sido salvas pela aplicação de maiores gastos com assistência de saúde (p. 246 da $5^{a}$. e p. 273-4 da $7^{\text {a }}$. edição) ${ }^{18,69}$.

B\&C fazem menção à Dworkin que propõe, da $5^{\mathrm{a}}$. à $7^{\mathrm{a}}$. edição, que tentemos imaginar uma "seguridade prudente" ideal, que prevê cuidados de saúde em um mercado livre e não subsidiado, sem todas as deficiências que atualmente caracterizam os mercados na assistência de da saúde (p. 246 da $5^{\text {a }}$. e p. $273-4$ da $7^{\text {a }}$. edição) ${ }^{18,69}$. Este mercado ideal pressupõe uma distribuição justa de riqueza e de renda, informações plenas sobre benefícios, custos e riscos de vários procedimentos médicos, e que não seja levada em consideração a probabilidade de morrer, com ou sem risco de morte, de doenças e acidentes. Nestas circunstâncias, qualquer montante que uma comunidade bem informada decida investir em assistência de saúde será justa, assim como o padrão de distribuição de sua escolha (p. 246 da $5^{a}$. e p. 273-4 da $7^{\mathrm{a}}$. edição) ${ }^{18,69}$.

$\mathrm{Na} 6^{\mathrm{a}}$. e continuando na $7^{\mathrm{a}}$. edição passaram a afirmar que países sem um sistema abrangente e coerente de financiamento e distribuição de assistência à saúde, tendo os Estados Unidos como exemplo primeiro, estão fadados a continuar no caminho de altos custos e grandes números de cidadãos desprotegidos até que mudanças significativas ocorram (p. 280 e p. 293, respectivamente $)^{18,70}$. A referência ao exemplo dos Estados Unidos foi excluída na $7^{\text {a }}$. edição (p. 293) $)^{18}$. 
$\mathrm{Na} 6^{\mathrm{a}}$. e na $7^{\mathrm{a}}$. edição continuam afirmando que estes países devem melhorar tanto a utilidade (eficiência) quanto a justiça (enquanto o que é justo e equidade). Apesar de tanto a justiça quanto a utilidade parecerem valores opostos, ambas são indispensáveis no delineamento de um sistema de assistência de saúde (p. 280 e p. 293, respectivamente) ${ }^{18,70}$. Assim, a posição assumida pelos autores nestas duas últimas edições se mostra, nas anteriores, mais distante da presente, porém, mais próxima das críticas recebidas por $B \& C$, em especial no que tange à busca de ideais solidários, comumente apresentados nos países periféricos e que defendem uma Bioética nesse sentido ${ }^{24}$.

\section{Princípio da necessidade}

$\mathrm{Na} 1^{\mathrm{a}}$. e na $2^{\mathrm{a}}$. edição $\mathrm{B} \& \mathrm{C}$ apenas explicam no que consistiria o princípio da necessidade, uma regulação da justa distribuição baseada no que se compreende por necessidade (p. 192 e p. 189, na ordem) $)^{31,68}$. Além disso, recomendam seu uso em conjunto com o princípio da justiça formal (p. 192 e p. 189 , na sequência) $)^{31,68}$ - o qual é mais conhecido atualmente no contexto latino-americao, e mesmo internacional, por equidade.

Apesar de mencionarem na $1^{\text {a }}$. edição, apenas a partir da $2^{\mathrm{a}}$. explicam o que seria uma necessidade "fundamental", sendo aquilo que, caso a pessoa seja privada, seria ferida ou seriamente afetada da forma mais basilar ( $p$. $261)^{68}$. Trata-se de um novo instituto acrescido à obra, pois B\&C, por meio de diversos deles, tentaram todo o tempo definir em que consistiria o mínimo a ser provido em saúde.

Foi assim que, na $3^{a}$. edição incluíram explicação sobre o que seriam as "necessidades de assistência à saúde", as quais englobariam todo o necessário na assistência à saúde para atingir, restaurar ou manter as espécies em "típico funcionamento" (p. 269-70) ${ }^{17}$, o que foi mantido até a última edição (p. 257) ${ }^{18}$. 
Este "típico funcionamento" é mencionado na obra de B\&C como referência ao que seria um estado de saúde normal. Daniels, autor que foi trazido ao Principialismo ainda na $3^{\text {a }}$. edição, mas citado em assuntos diversos a este, foi quem criou uma lista de necessidades sanitárias, como nutrição e abrigos adequados, ambiente livre de contaminação e exercício físico, as quais seriam essenciais para manter, restaurar, prevenir ou compensar o "típico funcionamento" que B\&C mencionam ${ }^{79}$.

\section{Pesquisa clínica}

Já na $1^{\mathrm{a}}$. edição, $\mathrm{B} \& C$ discutem temas relacionados à pesquisa clínica com seres humanos no capítulo sobre a justiça ${ }^{31}$. Nesta edição, questionam quais classes de pessoas poderiam ser sujeitos de pesquisa, comentando, principalmente, sobre prisioneiros, fetos, crianças e institucionalizados por doenças mentais (p. 181-2) ${ }^{31}$, o que perdurou apenas até a $5^{a}$. edição ( $p$. $333)^{69}$.

Além destas, somente na $1^{\text {a }}$. edição defendiam o afastamento de pessoas não pertencentes a nenhuma das classes previamente estabelecidas, mas que apresentassem qualquer outra característica moralmente relevante ( $p$. 181-2) ${ }^{31}$. Também, tão somente nas duas edições iniciais, escreveram que se os recursos não fossem escassos, os médicos deveriam afastar das pesquisas apenas aquelas pessoas que não se beneficiariam dela (p.194 e p. 212, na ordem) $)^{31,68}$.

Apenas nestas duas primeiras edições da obra trazem um debate sobre a posição de uma associação (American Bar Association) e de um periódico científico (The New England Journal of Medicine) sobre a possibilidade, ou não, de deficientes mentais participarem de pesquisas clínicas (p. 182-3 e p. 196-7, respectivamente $)^{31,68}$. A associação defendia a posição de que nenhuma pesquisa clínica poderia ser feita com deficientes mentais, a não ser que estivesse diretamente relacionada com a etiologia, patogênese, prevenção, diagnóstico ou tratamento da doença propriamente dita - o que não autorizaria 
estudos como o de Willowbrook (p. 182-3 e p. 196-7, respectivamente) ${ }^{31,68}$. O periódico, por sua vez, defendia que estas pesquisas seriam muito importantes à compreensão da hepatite, assim, potencialmente valiosas às crianças da instituição, não havendo prejuízos a elas porque provavelmente contrairiam hepatite de qualquer jeito, além disso, que foram realizadas por competentes pesquisadores - defendendo o estudo de Willowbrook (p. 182-3 e p. 196-7, respectivamente $)^{31,68}$. Nas edições seguintes, o caso de Willowbrook só continuou mencionado no apêndice do livro.

Apenas na $2^{a}$. edição debatem a possibilidade, ou não, de se compensar um sujeito de pesquisa por dano sofrido durante o ensaio não em consequência de negligência, quando este voluntariamente consentiu em participar do estudo (p. 194-5) ${ }^{68}$. Este debate excluído foi da obra sem contudo os autores apresentarem quaisquer respostas aos questionamentos.

Apenas na $2^{\mathrm{a}}$. edição, e ao contrário do que afirmavam na $1^{\mathrm{a}}$. (p. 196) ${ }^{31}$, os critérios objetivos de escolha de sujeitos de pesquisa foram criticados por parecerem mais subjetivamente calcados do que objetivamente (p. 211) ${ }^{68}$. Explicaram que, apesar disso, estes critérios ainda não podiam ser considerados arbitrários, eis que reduzíveis a critérios médicos ou utilitários também, apesar das críticas (p. 213-4) ${ }^{68}$.

Unicamente na $3^{a}$. edição havia referência ao exemplo das técnicas de duplo-cego, que, segundo os autores, são erroneamente relacionadas ao princípio da justiça ${ }^{17}$. B\&C defendem que a discussão sobre estas pesquisas acontecem mais por falta de informação aos pacientes, ou seja, relacionadas ao princípio da autonomia. Segundo eles, até mesmo os princípios da beneficência e da não-maleficência seriam invocáveis, mas não o da justiça ( $p$. $256-7)^{17}$.

Trata-se de uma breve passagem da $3^{a}$. edição que, ao contrário de trazer o tema à discussão, só reforçou que B\&C reduzem a exploração de sujeitos de pesquisas nesta técnica à falta de informação, em uma tentativa de afastar a discussão do âmbito da justiça, a qual condenaria tais experimentos, 
ainda mais se tomado sob o enfoque dos países latinoamericanos (assim como outros periféricos), os quais devem ter sua visão prevalescendo, pois são os que mais sofrem com isso ${ }^{23}$.

Apesar disso, da $5^{\text {a }}$. até a última edição, sobre as pesquisas terapêuticas, passaram a afirmar categoricamente que a justiça, enquanto justo acesso à pesquisa (que inclui tanto o direito de participação quanto o acesso aos resultados) se tornou tão importante quanto a proteção contra a exploração (p. 226-7 da $5^{\text {a }}$. e p. 250 da $7^{\text {a }}$. $)^{18,69}$.

Apenas na $6^{a}$. e na $7^{\mathrm{a}}$. edição, questionaram a exclusão categórica dasa pessoas economicamente desfavorecidas. Uma estratégia que, segundo B\&C, seria tentadora, pois protegeria os interesses destas pessoas e eliminaria $\mathrm{O}$ problema da injusta exploração (p. 254 e p. 268, respectivamente $)^{18,70} . \mathrm{Em}$ tempo, contudo, também ressaltaram que seria prejudicial às suas liberdades de escolha e aos seus interesses econômicos, além de uma forma inescusável e paternalista de discriminação e de privação, discriminando, marginalizando, excluindo e estigmatizando estas pessoas (p. 254 e p. 268, respectivamente) $)^{18,70}$.

$\mathrm{Na} 6^{\mathrm{a}}$. e na $7^{\mathrm{a}}$. edição passaram também a tratar da questão do "indevido induzimento" e da "injusta remuneração" na participação de pesquisas ${ }^{18,70}$. Isso porque, enquanto em tempos passados os descobrimentos farmacêuticos podiam ser difundidos com a finalidade maior de promover a saúde, hoje, com uma das maiores participações no mercado mundial, a indústria farmacêutica representa um dos focos de discussão bioética sobre a comercialização da saúde ${ }^{24}$.

Segundo B\&C, a "injusta remuneração" ocorre quando o sujeito recebe um pagamento muito pequeno por sua participação, sendo considerado injusto não por exercer uma coerção velada a participar da pesquisa (como ocorre no "indevido induzimento"), mas porque a indústria farmacêutica lucrou milhares de vezes mais (p. 256 e p. 269, na sequência) $)^{18,70}$. 
Esta postura, de certa forma, fere o justo compartilhamento de benefícios, ficando os sujeitos de pesquisa com todos os riscos da participação na pesquisa e a indústria farmacêutica com exacerbados lucros. O que se torna ainda mais moralmente injustificável, se lembrarmos que as novas descobertas provavelmente serão destinadas a quem "pode" comprar, o que provavelmente não incluirá os sujeitos que participaram da pesquisa ${ }^{24}$.

Nas duas últimas edições, esclareceram também que uma remuneração irresistivelmente atrativa levaria ao "indevido induzimento", situação em que, muitas vezes, não determina apenas a participação, ou não, na pesquisa, mas também envolve assumir riscos de sérios danos, que não seriam aceitos em outras condições (p. 256 e 269, na ordem) ${ }^{18,70}$. Trata-se do "outro lado da moeda" de se permitir qualquer das formas de remuneração em valores elevados.

Apenas na $6^{\text {a }}$. edição $B \& C$ realçam e chamam de manipulativas algumas ofertas de recompensas a sujeitos de pesquisa. Relatam que algumas pessoas se sentem pressionadas a se inscrever em ensaios clínicos, mesmo quando a inscrição se dizia voluntária, não representando exatamente uma coerção a participar, mas, ao menos, uma manipulação (p. 255 ${ }^{70}$.

Novamente se percebe uma tentativa dos autores do Principialismo de tornar sua obra mais homogênea com a literatura internacional, a qual costuma criticá-la por ter uma visão excessivamente autonomista e colonizadora. Isso é demonstrado com a inclusão, a partir da $6^{\mathrm{a}}$. edição, de novos questionamentos sobre a participação de sujeitos de pesquisa remunerados nos ensaios clínicos que envolvem riscos às pessoas e, na $7^{a}$. edição com a alteração do tópico "Vulnerabilidade e Exploração" para "Vulnerabilidade, Exploração e Discriminação na Pesquisa".

No entanto, excluíram da obra assuntos presentes somente até a $3^{\mathrm{a}}$. edição, como quem deveria ser afastado em situações de recursos escassos, ressarcimento a quem sofreu dano nas pesquisas, o estudo de Willowbrook e o duplo-cego - questões fundamentais para o contexto da Bioética. Além disso, 
os diversos documentos internacionais sobre o tema hoje existentes, como a Declaração de Helsinque, foram simplesmente ignorados.

\section{Prevenção}

Desde a $1^{a}$. edição, B\&C já questionaram se o Estado deveria investir mais recursos em medicina curativa ou preventiva (p. 190) ${ }^{31}$, o que foi ampliado ao longo das edições seguintes. A partir da $2^{a}$, , ao lado da prevenção, o incremento da qualidade de vida dos indivíduos foi incluído na discussão ${ }^{68}$. Para eles estes fatores poderiam ser mais eficientes na promoção de saúde do que a medicina exclusivamente curativa (p. 204) ${ }^{68}$. Apenas nesta $2^{a}$. edição, explicaram que a prevenção consiste em fortalecer os indivíduos, modificar seus estilos de vida, seus modelos comportamentais e seus meios de inserção (p. 207) ${ }^{68}$. Afirmaram, porém, que programas eficientes e eficazes embasados nos estilos de vida e modelos comportamentais logo esbarram nos limites do princípio da autonomia (p. 207) ${ }^{68}$.

$\mathrm{Na} 1^{\mathrm{a}}$. e na $2^{\mathrm{a}}$. edição chegaram a afirmar que alocar recursos na assistência à saúde ou na tecnologia em detrimento de se melhorar a qualidade de vida das pessoas seria o mesmo que "desalocar" recursos ( $p$. 189-90 da $1^{a}$. e p. 204 da $2^{a}$. edição) $)^{31,68}$. Apenas na $3^{a}$. edição citam estudos que comprovam que, estatisticamente, outras condições como a qualidade de vida são mais importantes do que o próprio implemento da saúde (p. 284) $)^{17}$. Nela, incluíram, ao lado da vacinação de pólio já presente na $2^{a}$. edição ( $p$. 204-5 $)^{17}$, o exemplo da odontologia preventiva como modelo de sucesso na prevenção (p. 287-8) ${ }^{17}$.

Unicamente nesta $3^{a}$. edição, ao mesmo tempo em que afirmavam que princípios utilitários requereriam estratégias preventivas porque maximizariam a utilidade social, B\&C incluíram o relato de que tem se questionado o modelo preventivo porque, apesar de evitar doenças futuras dispendiosas, faz aumentar o número de atendimentos na medida em que as pessoas vivem mais (p. 288) ${ }^{17}$. 
Da $2^{\mathrm{a}}$. à $4^{\mathrm{a}}$. edição relataram que as sociedades em geral preferem que os gastos em saúde se concentrem na medicina curativa, porque se destinam a pessoas identificáveis, apesar de na prevenção estes gastos serem mais efetivos e eficientes (p. 204-5 da $2^{a}$. e p. 363-428 da $4^{a}$. edição) ${ }^{16,68}$.

Da $4^{\mathrm{a}}$. à $7^{\mathrm{a}}$. edição, passaram a afirmar de que tudo o que é gasto nas comunidades pobres com prevenção, como assistência pré-natal, salva vidas inúmeras vezes mais no futuro (p. 364 da $4^{a}$. e p. 282 da $7^{a}$. edição) ${ }^{16,18}$, fato que levou B\&C, a partir da $5^{a}$. à última edição, a ter a "intuição moral" de que existirá um conflito entre alocar recursos no imediato salvamento de vidas ou alocar para prevenir que mais pessoas venham a precisar disso (p. 288 da $5^{a}$. e p. 282 da $7^{a}$. edição) $)^{69,18}$.

Da $3^{a}$. à $5^{a}$. edição explicam o verdadeiro motivo desta discussão, a qual, mais uma vez incidiu no aumento de custos (p. 282-3 da $3^{a}$. e p. 248 da $5^{a}$. edição $)^{17,69}$. Assim, esclareciam que o cerne do problema não estava exatamente em qual delas preferencialmente alocar - se na medicina curativa ou na preventiva - visto que já era claro que esta salvava muito mais vidas.

Nesse sentido, apenas da $3^{a}$. à $5^{a}$. edição reconheceram que a prevenção de hábitos deletérios/condutas de risco, por meio de mudanças de estilos de vida e de atitudes preventivas, podem não levar à desejada redução de gastos, eis que, no final das contas, os hábitos e condutas prevenidas poderiam ter resultado em mortes prematuras, o que, por sua vez, evitaria que estas pessoas vivessem mais e desenvolvessem debilidades crônicas, mais dispendiosas (p. 282-3 da $3^{a}$. e p. 248 da $5^{a}$. edição) $)^{17,69}$.

Mais uma vez, portanto, um tema de fundamental importância para a saúde como um todo foi tratado por B\&C como uma mera questão de custobenefício. Os autores chegam a afirmar que investir recursos em prevenção seria o mesmo que "desalocar", pois poderia salvar mais vidas e aumentar os gastos em saúde. Isso vai no sentido contrário a tudo o que a Bioética de Intervenção vem tentando promover: a utilização de uma metodologia 
utilitarista e consequencialistamente solidária, comprometida com a transformação social, de forma a assegurar a equidade aos diferentes sujeitos $^{63}$.

Deve ser ressaltado que a Bioética de Intervenção também é utilitarista, porém, sempre buscando o cálculo das melhores consequências aos sujeitos envolvidos, e nunca os menores gastos pela simples justificativa de se gastar menos, eis que é responsável por assegurar de maneira prática e palpável as garantias universais e indivisíveis relativas a direitos de primeira (individuais), de segunda (sociais e econômicos) e de terceira (difusos) gerações, para todos os grupos humanos, mas, particularmente, para os segmentos historicamente vulneráveis e menos privilegiados ${ }^{24}$.

\section{Teorias do princípio da justiça segundo B\&C}

$\mathrm{Na} 2^{\mathrm{a}}$. edição, B\&C incluíram explicação sobre o foco de cada uma das teorias da justiça que consideram relevantes: Igualitária (igual acesso a bens que todos desejam); Marxista (necessidade); Libertária (direito à liberdade social e econômica - segundo critérios de contribuição e mérito); e Utilitária (combinação de utilidade pública e privada maximizadas) (p. 188-9) ${ }^{68}$. O uso de cada uma depende do que se deseja dar prioridade.

A $2^{\mathrm{a}}$. edição foi também a primeira a incluir uma conclusão ao final dos capítulos sobre os princípios. Nesta, assim como nas conclusões seguintes, havia considerações sobre que não se deveria utilizar apenas uma teoria da justiça, mas sim várias, já que cada uma delas foi construída sob diferentes concepções; sendo assim, segundo eles, cada uma absorveu apenas parte das diversidades que a vida envolve (p. 216) ${ }^{68}$.

Nesta conclusão, assim como nas seguintes, B\&C explicam que as teorias da justiça, à primeira vista, parecem opostas, mas que, apesar disso, nenhuma sociedade consegue seguir unicamente uma delas. Assim, não 
devemos ficar surpresos se teorias conflitantes emergirem; certo é que, hoje, existem várias teorias de justiça plausíveis e igualmente viáveis (p. 217) ${ }^{68}$.

Foi também na $2^{\mathrm{a}}$. edição que começaram a explicar melhor a Teoria da Justiça de Rawls. Segundo B\&C, esse autor desafia as teorias de cunho libertário, pois prega que as distribuições de bens devem ser iguais a todos, ao menos que uma detertminada desigualdade possa gerar mais benefícios a todos (p. 190-1) ${ }^{68}$. Rawls foi um dos filósofos que defendeu que a justiça pode ser mais bem explicada em termos do que seria "justo", ao mesmo tempo em que afirma que talvez o conceito mais próximo de justiça no seu sentido mais amplo, seja "mérito", dando a cada um o que é seu por direito (p. 184) ${ }^{68}$.

Ampliando as explicações sobre a Teoria de Rawls, na $3^{a}$. edição B\&C acrescentam que ele se utiliza de um ahistórico e hipotético modelo de contrato social em que princípios válidos de justiça são aqueles que todos concordariam se pudessem livremente considerar uma posição social inicial que chama apenas de "posição original" (p. 269) ${ }^{17}$. Este conceito de posição original, segundo Rawls, se refere à uma situação hipotética onde cidadãos livres integram um contrato social para evitar perda de liberdades e gerar igualdade de oportunidades. Esta posição original é a mesma de um contratante que desconhece sua situação atual frente ao contrato que irá celebrar, assim como desconhece as consequências de seu acordo - ao que Rawls denomina de "véu da ignorância"22,79.

Apenas nesta $3^{a}$. edição explicam que existe um equívoco comum em relação à justiça, pois na literatura ética biomédica, o termo "justo" costuma ser utilizado em sentido amplo e equivocado para se referir ao que é justificável ou moralmente correto (p. 256-7) $)^{17}$

Assim, para B\&C, muitos dos conflitos tratados pela justiça constituem, na verdade, conflitos relacionados à autonomia, beneficência ou nãomaleficência (p. 256-7) ${ }^{17}$. Este é, sem dúvida, um dos grandes problemas encontrados na presente análise do Princípio da Justiça na obra de B\&C pois representa uma clara redução do âmbito de atuação da justiça, pois muitos dos 
conflitos analisados poderiam ser substituídos por um dos outros três princípios do Principialismo, dependendo do caso. Tal posição vai no sentido contrário do que o mundo ocidental vem construindo ao longo das últimas décadas, eis que direitos sociais, incluindo o direito à saúde, antes pautados na beneficência, começaram ser paulatinamente fundados na justiça ${ }^{79}$.

Em continuidade, na $4^{a}$. edição, não apenas afirmam que a Teoria da Justiça desafia as teorias libertárias, mas também as utilitárias ${ }^{16}$. Explicam que Rawls entende a justiça como aquilo que é razoavelmente justo, ou seja, por meio de normas de cooperação acordadas por pessoas livres e iguais que participam das atividades sociais com respeito mútuo - o que também é consistente com a perspectiva rawlsiana do equilíbrio reflexivo e da coerência (p. 339-40) $)^{16}$.

$\mathrm{Na} 3^{\mathrm{a}}$. e na $4^{\mathrm{a}}$. edição, continuaram defendendo que não existe uma única teoria da justiça que cubra todas as diversas perspectivas possíveis, pois isso seria impossível (p. 256 e p.326-7, na sequência) ${ }^{16,17}$. Apenas na $3^{a}$. edição elucidam que o que torna uma teoria correta é o fato dela ter sido escolhida livremente pelos membros de um grupo (p. 267) ${ }^{17}$.

A partir da $4^{\mathrm{a}}$. edição incluíram na obra a Teoria da Justiça Comunitária, como uma das doutrinas de base do princípio da justiça, explicando que alguns de seus autores se abstraem da noção de justiça se baseando na solidariedade, a qual representa tanto uma virtude pessoal de comprometimento quanto um princípio de moralidade social baseado nos valores compartilhados por um grupo (p. 338) ${ }^{16}$, o que foi mantido na $5^{a}$. edição (p. 233) $)^{69}$.

Sobre a solidariedade, Oliva destaca que se deve tentar escapar da noção paternalista, típica da filosofia de política liberal, pois não provoca e nem estimula mudanças estruturais, devendo-se buscar uma proposta de conceito de solidariedade que assuma as assimetrias nas relações humanas, buscando o bem humano como consequência das diminuições dos sofrimentos ${ }^{79}$. 
$\mathrm{Na} 6^{\mathrm{a}}$. edição, abandonando a ideia central de Justiça Comunitária, passaram a buscar embasamento nas Teorias Cosmopolitas. Segundo B\&C, são elas, hoje, que tratam de teorias éticas e políticas que abordam explicitamente as questões de justiça global (p. 264) ${ }^{70}$. Na $7^{\mathrm{a}}$. edição, trocaram o nome Teoria Cosmopolita por "Teoria Global" (p. 277) ${ }^{18}$. Assim, B\&C explicam que tal abordagem os influenciou fortemente neste volume, tendo, como ponto de partida, condições sociais amplas e normalmente também catastróficas - em particular, fome, pobreza e epidemias (p. 264) ${ }^{70}$. Este tema perdurou na $7^{\mathrm{a}}$. edição (p. 277) ${ }^{18}$.

$\mathrm{Na} 6^{\mathrm{a}}$. edição afirmaram que a Teoria Cosmopolita captura um aspecto crítico da justiça igualitária. A falta de saúde e as crescentes desigualdades são o resultado de muitos efeitos interativos. Seria absurdo, na Teoria da Justiça, tomar como único parâmetro a distribuição de assistência de saúde, ignorando as muitas causas de baixa saúde e pouca distribuição de assistência (p. 266) ${ }^{70}$.

Trata-se de uma clara mudança de posição de B\&C, que antes focavam seu Principialismo no relacionamento médico-paciente, esquecendo de outros problemas que circundam a saúde, em especial, os problemas mais comuns afetos às nações periféricas, o que provavelmente se deu em virtude das fortes críticas que recebeream neste sentido, incluídas aquelas já mencionadas e oriundas da América Latina.

Outro destaque da $6^{a}$. edição se concentra no reconhecimento de que as privações de educação causam privações de saúde, assim como de que problemas de saúde podem tornar difícil a obtenção de uma boa educação ( $p$. $266)^{70}$. Por este motivo que, apenas prima facie, poderia se pensar que o favorecimento de pessoas com melhor nível de educação e que, por conseguinte, poderiam aproveitar melhor os recursos de saúde, seria justificável (p. 266) ${ }^{70}$. Contudo, esta prática geraria uma iniquidade enorme em termos de loteria social, porque as pessoas que não receberam educação adequada não a tiveram por fatores extrínsecos à sua vontade. Igual consideração caberia a critérios de idade, sexo e raça ${ }^{79}$. 
Nesse sentido, nas duas últimas edições, explicam que qualquer uma das dimensões fundamentais do bem-estar propostas por Powers e Faden poderia afetar o desenvolvimento das outras, e todas podem promover saúde precária (p. 266 e p. 278 , na ordem ${ }^{18,70}$. Em algumas sociedades, chega-se a ter uma constante combinação de privações. Desigualdades, nestas circunstâncias, estão entre as mais urgentes que uma teoria da justiça deveria solucionar, independentemente do país em que ocorram (p. 266 e p. 278, na ordem) ${ }^{18,70}$.

$\mathrm{Na} 6^{\mathrm{a}}$. edição e continuando na $7^{\mathrm{a}}$,, acrescentaram outras citações relevantes, como a de Singer, o qual, fundamentado na beneficência utilitária, pauta seu trabalho nas obrigações dos agentes, pessoas e governos, onde 0 cerne das questões não recai sobre a moralidade das escolhas individuais, mas sobre a moralidade da estrutura básica da sociedade a partir de onde as escolhas morais são feitas (p. 265 e p. 278 , respectivamente) $)^{18,70}$.

Nestas duas últimas edições, incluíram Pogge, defensor da Teoria Cosmopolita (ou Global), que argumenta que a tese de Rawls estaria limitada a nações e a Estados, limitando indevidamente a aplicação da teoria da justiça. Para ele, uma teoria moral consistente aplicaria os princípios da justiça a qualquer situação (p. 265 e p. 278 , na ordem $)^{18,70}$.

Por fim, já na última edição, a questão das teorias da justiça ganhou todo um item, aliás, o primeiro da obra a apresentar uma conclusão como subítem (p. 262) ${ }^{18}$. B\&C voltam a tratar da Teoria do Bem-Estar, com as seis dimensões do bem-estar, desenvolvida especialmente para a Bioética, Saúde Pública e Políticas de Saúde, de Powers e Faden (p. 260-1 $)^{18}$.

Já na $7^{\text {a }}$. edição, trazem à baila a Teoria das Capacidades, partindo do pressuposto de que a oportunidade para se atingir estados de funcionamento apropriado e bem-estar são de significância moral básica e que a liberdade para se atingir estes estados deveria ser analisada de acordo com a linguagem das capacidades (p. 259) ${ }^{18}$. Nesta teoria, a qualidade das vidas das pessoas é dependente do que elas são capazes de conquistar. Citam Sen como precursor 
da teoria, assim como Nussbaum, como defensora da teoria na Ética Biomédica, a qual estabelece o que seria "justiça social" e as "fronteiras da justiça", incluindo temas como incapacitados, globalmente pobres e animais não humanos (p. 259) ${ }^{18}$.

No que tange à Teoria Comunitária, na $7^{\text {a }}$. edição incluíram outras citações importantes. Na primeira, de Taylor (segundo B\&C, o maior pensador comunitarista), contestaram a tese da prioridade nos direitos individuais em detrimento do bem comum, defendendo que mesmo a autonomia baseada no individualismo não poderia ser desenvolvida na ausência de estruturas de família ou de outras relacionadas à comunidade (p. 258) ${ }^{18}$. A segunda, de Callahan, defende que se deve proclamar políticas públicas a partir de um consenso comum sobre o "bem" na sociedade, mais do que sobre direitos individuais (p. 258) ${ }^{18}$.

\section{Mudanças de nomenclatura}

$\mathrm{Na} 1^{a}$. (p. 184$)^{31}$ e na $2^{a}$. edição (p. 197-8) ${ }^{68}$ se referiram a pessoas com deficiência mental chamando-as de pessoas com "lentidão" ("slowness"). Na $3^{a}$., passaram a se referir por pessoas com "retardamento" ("retardation" - p. $271)^{17}$. Na $4^{\mathrm{a}}$., por fim, alteraram para pessoas "com dificuldade de leitura ou deficiência mental" ("reading difficulties or mental deficiencies" - p. 342) ${ }^{16}$.

$\mathrm{Na} 5^{\mathrm{a}}$. edição se referiram a afrodescendentes por "africanosamericanos" ("African Americans" - p. 238) ${ }^{69}$. Na 6 ${ }^{\mathrm{a}}$., trocaram por "negros" ("blacks" - p. 251) ${ }^{70}$.

$\mathrm{Na} 1^{\mathrm{a}}$. edição falaram em "hábitos deletérios voluntários" ("individual's risk-taking" - p. 191) ${ }^{31}$, na $2^{a}$., passaram a usar "condutas de risco" ("risky conducts" - p. 207)

$\mathrm{Na} 3^{\mathrm{a}}$. edição trocaram o "valor social" ("social worth" - p. 202) ${ }^{68}$ das pessoas presente na $2^{a}$. edição, por "valor social comparado" ("individuals' 
comparative social worth" - p. 300 $)^{17}$, ao falarem sobre critérios de seleção e alocação de pacientes.

$\mathrm{Na} 6^{\text {a }}$. edição falaram em Teorias Cosmopolitas ("cosmopolitan theories" - p. 264) ${ }^{70}$, na $7^{a}$.edição, trocaram essa expressão por Teorias Globais ("global theories" - p. 277) ${ }^{18}$.

Estas alterações, aparentemente sem relevância, refletem a mudança de contexto estadunidense tanto do ponto de vista político quanto do social, assim como se enquadram às novas posturas que foram sendo adotadas pelos autores $B \& C$ no sentido de se adequar à literatura bioética, que sempre teceu críticas aos dois. 


\section{CONSIDERAÇÕES FINAIS}

A $4^{\mathrm{a}}$. edição foi a primeira a tocar no tema da moralidade comum e em sua teoria, apesar de ser a primeira a iniciar a construção da ideia de prescindibilidade de uma teoria do Principialismo. Nessa edição, a definição inicial de moralidade comum era a de uma compilação de normas de conduta humana "socialmente aprovadas"; na $5^{\text {a }}$. passou a ser um conjunto de normas compartilhadas por "pessoas moralmente sérias"; na $6^{a}$. e na $7^{a}$., um conjunto de normas compartilhadas por todas as "pessoas comprometidas com a moralidade". Assim, B\&C foram reduzindo o âmbito de abrangência da moralidade comum, tornando mais fácil justificar a pretensa universalidade do Principialismo, pois o aplicavam a apenas grupos pré-determinados.

Em consonância, partiram da defesa de um universalismo no sentido de todos terem a mesma moralidade comum (o qual não conseguiram sustentar) para a defesa de uma proposta onde todos possuem uma moralidade comum, mesmo que cada um a sua, apesar de esta noção não corresponder ao que a moralidade comum de fato representa.

$\mathrm{Na} 5^{\mathrm{a}}$. edição, para se esquivar das críticas, reconhecem que não irão mais defender a existência de uma única moralidade comum, assim como de sua Teoria, chegando a afirmar que apresentarão sua própria versão de teoria da moralidade comum. Na $6^{\mathrm{a}}$. e na $7^{\mathrm{a}}$. edição, B\&C voltam atrás, passando a defender o que haviam inicialmente apresentado, a existência de uma moralidade comum universal e a aplicabilidade da Teoria da Moralidade Comum de Gert e Clouser.

Sobre a resposta à crítica da falta de um procedimento claro de aplicação dos princípios, $B \& C$ expressam ser uma virtude a sua obra requerer especificação, contudo, ainda não conseguiram suprir a falta de um procedimento claro. Já na $6^{a}$. edição, tomam o método do equilíbrio reflexivo da Teoria da Justiça de Rawls como a referência a ser utilizada. 
Assim, pode-se afirmar que a fundamentação do Principialismo foi tomada da Teoria da Moralidade Comum de Gert e Clouser e o método de aplicação concreta dos princípios da Teoria da Justiça de Rawls.

Apesar disso, a partir da $2^{\mathrm{a}}$. edição, B\&C passaram a reconhecer a necessidade de utilizar concomitante várias teorias de justiça, pois nenhuma, isoladamente, seria capaz de abarcar todas as diversidades que a vida envolve.

A obra como um todo se utiliza de exemplos para explicar a maioria dos institutos que reclama, no entanto, carece de definições ou de modelos práticos em geral.

A inclusão da palavra Bioética (que já existia na obra) no capítulo sobre o Princípio da Justiça surgiu apenas na $6^{a}$. edição, a mesma onde houve a inclusão de um item inteiro sobre vulnerabilidade e exploração. O tema da vulnerabilidade é tratado pelos autores sob o enfoque principal do que se deveria evitar, ressaltando os perigos da rotulagem e da estereotipação dos sujeitos, assim como do uso de discriminação desarrazoada, que poderiam desvirtuar o conceito.

Por outro lado, diversas questões sobre Ética em Pesquisa com Seres Humanos que hoje ainda se encontram na pauta internacional foram simplesmente excluídas da obra até a $3^{a}$. edição, como, por exemplo, quais sujeitos deveriam ser afastados, ressarcimento a quem sofreu danos, o estudo de Willowbrook e uso de duplo-cego. Além disso, os diversos documentos internacionais sobre o tema hoje existentes, como a Declaração de Helsinque, foram simplesmente ignorados.

A $6^{\mathrm{a}}$. e a $7^{\mathrm{a}}$. edições podem ser consideradas as mais homogêneas em relação à literatura internacional, assim como as que mais se distanciam das iniciais. Nelas, os autores buscaram defender políticas globais, reconheceram a existência de outras dimensões da saúde que não apenas a assistência 
curativa, afirmaram a importância concomitante do uso da utilidade e da justiça no delineamento de sistemas saúde, questionaram a exclusão de imediato dos sujeitos de pesquisa economicamente desfavorecidos, discutiram a questão da "indução indevida" como forma de manipulação à participação em pesquisas e a "remuneração injusta" como forma de desrespeito ao princípio do compartilhamento de benefícios.

Apesar disso, a posição de $\mathrm{B} \& \mathrm{C}$ em relação à prevenção continuou pautada no caráter exclusivamente econômico, com a defesa de que sua ampliação geraria maiores gastos em saúde de uma forma geral, mesmo reconhecendo que poderia salvar mais vidas do que o modelo curativo. Neste sentido, deixam claro ao longo da obra que a saúde representa um "bem" (e não um direito) a ser "dado" ou "concedido" segundo critérios de justa distribuição ou "comprado" por quem pode pagar (e jamais "conquistado"). A busca do que seria um direito à saúde por $B \& C$, assim como da definição de mínimo existencial e de tudo o que permeia a discussão de princípio da necessidade, não passaram de uma tentativa de se estabelecer o que ou o quanto o Estado deveria prover de saúde àqueles que não podem pagar.

Sobre a alocação de recursos em saúde, ao contrário do que se costuma discutir na Bioética latinoamericana, ou seja, a busca da distribuição equitativa de recursos escassos na saúde, a discussão travada por B\&C se resume a propor a distribuição de recursos da maneira mais próxima a um processo de compra e venda em um livre mercado. Os autores, afastando qualquer caráter solidário de distribuição de recursos, pregam o uso horizontal e mecânico do Princípio da Justiça como a forma mais apropriada de decidir sobre alocação de recursos nos dias atuais. Portanto, apresentam uma proposta completamente diferente dos autores latinoamericanos, os quais buscam garantir o cumprimento de direitos (tal qual insculpidos em declarações internacionais), e não alegando a incapacidade do caráter solidário de lidar com questões de ordem financeira ${ }^{55,79}$.

A questão da privacidade é relacionada ao princípio do respeito pela autonomia, e não ao da justiça, o que segue uma constante na obra: o 
individual sufocando o coletivo - na medida em que B\&C sempre supervalorizam a autonomia. $\mathrm{Na} 3^{\mathrm{a}}$. edição, adicionam a regra da confidencialidade, mas isso acontece somente até a $5^{\text {a }}$. edição, onde ambas são excluídas. Isso vai de encontro ao que a Declaração Universal sobre Bioética e Direitos Humanos (2005) prevê, a qual possui a privacidade e a confidencialidade como princípios centrais e individualizados.

Ao tratarem do princípio da justiça formal, ou da igualdade formal, ou mesmo da equidade (para eles, sinônimos), o tomam nos mesmos termos aristotélicos. Contudo, o trabalham ao lado da regra da justa oportunidade, onde, se uma pessoa é responsável pela desvantagem com a qual se encontra na sociedade, ela deve ser privada de auferir benefícios por este motivo (por meio de uma distribuição segundo a justiça distributiva), sopesando-se o instituto.

Diante de tudo isso, o que se pode constatar é que as mudanças ocorridas ao longo das sete edições, seja quando B\&C incluem e tentam definir o que seria moralidade comum, seja quando trabalham o princípio da justiça sob os diversos enfoques aqui levantados, ressaltam, como pano de fundo, a tentativa de defesa da pretensa universalidade no Principialismo.

Isso tudo reflete a impossibilidade de o Principialismo ser aplicado universalmente do ponto de vista teórico-estrutural, conforme levantado nesta tese, respeitando as condições sócio-econômicas e culturais específicas de cada país ou região, aspecto considerado, por exemplo, na Declaração Universal sobre Bioética e Direitos Humanos.

Na América Latina, especificamente, a Bioética de Intervenção trabalha temas relacionados com a justiça distributiva e outras questões históricas existentes na região a partir de um enfoque sócio-político que tem como base o critério universal dos direitos humanos, e não a partir da proposição economicista de limitação do acesso das pessoas a um determinado benefício por uma questão de custo-benefício, onde o mínimo existencial não representa sequer um direito básico de cidadania. 


\section{REFERÊNCIAS}

1 - Childress J. Principles-oriented Bioethics: an analysis and assessment from within. p. 72-98. In: Du Bose ER, et al (ed.). A matter of principles? Ferment in U.S. bioethics. Pennsylvania: Ed. Trinity; 1994.

2 - The Belmont Report: ethical principles and guidelines for the protection of human subjects of research. The National Commission for the Protection of Human Subjects of Biomedical and Behavioral Research. September 30th, 1978. Disponível em: http://videocast.nih.gov/pdf/ohrp_belmont_report.pdf > Acesso em: 29/11/2012.

3 - Garrafa V, Pessini L. Bioética: poder e injustiça. São Paulo: Ed. Loyola; 2003.

4 - Potter VR. Bioethics: bridge to the future. $1^{\text {a }}$ ed. Califórnia: Ed. Prentice-Hall; 1971.

5 - Patrão-Neves MC. A Fundamentação Antropológica da Bioética. Bioética (CFM). 1996; 4(1):07-16.

6 - Clouser KD, Gert B. A critique of principlism. The Journal of Medicine and Philosophy. 1990; 15(s.n.):219-236.

7 - Clouser KD. Common morality as an alternative to Principlism. Kennedy Institute of Ethics Journal. 1995; 5(3):219-236.

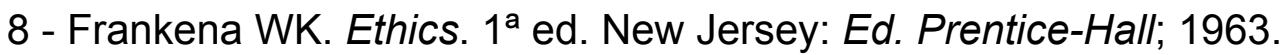

9 - Ross WD. The right and the good. Oxford: Claredon Press; 1930.

10 - P Mallia. Chapter 2: Critical Overview of Principlist Theories. p. 7-25. In: Health Care Principles through the phenomenology of relationships with patients. Ed. Springer; 2013.

11 - Holm, S. Not just autonomy - the principles of american biomedical ethics. J Med Ethics. 1995; 21(s.n.):332-338.

12 - Garrafa $V$. Da bioética de princípios a uma bioética interventiva. Bioética (CFM). 2005; 13(1):125-34.

13 - Du Bose ER, Hamel RP, O'Connel LJ. Introduction. p. 01-16. In: Du Bose $\mathrm{ER}$, et al (ed.). A matter of principles? Ferment in U.S. bioethics. Pennsylvania: Ed. Trinity; 1994. 
14 - Fox RC. The entry of U.S. Bioethics into the 1990s. p. 21-71. In: Du Bose $\mathrm{ER}$, et al (ed.). A matter of principles? Ferment in U.S. bioethics. Pennsylvania: Ed. Trinity; 1994.

15 - Luna F. Planteos clásicos y teoria de los princípios. p. 23-78. In: Luna F, Salles ALF. Bioética: nuevas reflexiones sobre debates clásicos. Buenos Aires: Ed. Fondo de Cultura Econômica; 2008.

16 - Beauchamp TL, Childress JF. Principles of biomedical ethics. $4^{\mathrm{a}}$ ed. Nova York: Oxford University Press; 1994.

17 - Beauchamp TL, Childress JF. Principles of biomedical ethics. $3^{\mathrm{a}}$ ed. Nova York: Oxford University Press; 1989.

18 - Beauchamp TL, Childress JF. Principles of biomedical ethics. $7^{\text {a }}$ ed. Nova York: Oxford University Press; 2013.

19 - Veatch RM. The foundations of Bioethics. Bioethics. 1999; 13(3/4):206217.

20 - Garrafa V, Azambuja LEO. Epistemología de la bioética - enfoque latinoamericano. Revista Colombiana de Bioética. 2009; 4(1):73-92.

21 - Segato RL. Identidades políticas/alteridades históricas: una crítica a las certezas del pluralismo global. Maguaré. 1999; s.n.(14): 114-147.

22 - Rawls JB. Uma Teoria da Justiça. São Paulo: Ed. Martins Fontes; 2008.

23 - Silva LESA, Drummond A, Garrafa V. Bioética de intervenção: uma prática politizada na responsabilidade social. Revista Universitas: Ciências da Saúde. 2011; 9(2): 111-119.

24 - Porto D, Garrafa V. Bioética de intervenção: considerações sobre a economia de mercado. Revista Bioética, Brasília. 2005; 13(1):111-123.

25 - Abel F. De Cambridge a Harvard y Georgetown, pasando por V.R. Potter. Bioética \& Debat. 2007; 13(50):01-05.

26 - Beecher H. Ethics and clinical research. The New England Journal of Medicine. 1966; 274(24): 1354-1360.

27 - Veatch RM. A Theory of Medical Ethics. New York: Ed. Basic Books; 1981.

28 - Engelhardt HT. The Foundations of Bioethics. New York: Oxford Press; 1986.

29 - Engelhardt HT. Fundamentos da Bioética. São Paulo: Ed. Loyola; 1998.

30 - Jonsen AR. The Birth of Bioethics. New York: Oxford Press; 1998. 
31 - Beauchamp TL, Childress JF. Principles of biomedical ethics. $1^{\text {a }}$ ed. Nova York: Oxford University Press; 1979.

32 - Serodio A. Revisitando o Principialismo: aplicações e insuficiências na abordagem dos problemas bioéticos nacionais. Revista Brasileira de Bioética 2008; 4(1-2):69-79.

33 - Selleti JC, Garrafa V. As raízes cristãs da autonomia. Petrópolis: Vozes; 2005.

34 - Hunt EK, Sherman HJ. História do Pensamento Econômico. Rio de Janeiro: Ed. Vozes; 2000.

35 - Compêndio do catecismo da Igreja Católica. $3^{\text {a }}$ ed. Petrópolis: Ed. Vozes; 1993.

36 - Gert B, Culver C, Clouser D. Principlism. p. 71-92. In: Bioethics: a return to fundamentals. New York: Oxford Press; 1997.

37 - Gert B, Culver C, Clouser D. Principlism. p. 99-127. In: Bioethics: a Systematic Approach. New York: Oxford Press; 2006.

38 - Ten Have H. Principlism: a western european appraisal. p. 101-120. In: Du Bose ER, et al (ed.). A matter of principles? Ferment in U.S. bioethics. Pennsylvania: Ed. Trinity; 1994.

39 - Holm S. Principles of Biomedical Ethics, $5^{\text {th }}$ ed. J Med Ethics. 2002; 28(jun):332.

40 - De Grazia D. Moving forward in bioethical theory: theories, cases and specified principlism. The Journal of Medicine and Philosophy. 2002; (17):511539.

41 - De Grazia D. Common Morality, Coherence, and the Principles of Biomedical Ethics. Kennedy Institute of Ethics Journal. 2003; 13(3):219-230.

42 - Beauchamp TL. A defense of the common morality. Kennedy Institute of Ethics Journal. 2003; 13(3): 259-274.

43 - Brand-Ballard J. Consistency, common morality, and reflective equilibrium. Kennedy Institute of Ethics Journal. 2003; 13(3): 231-258.

44 - De Grazia D, Beauchamp TL. Philosophy: Ethical principles and common morality. p. 37-53. In: Sugarman J, Sulmasy DP (ed.). Methods in Medical Ethics. Georgetown: Georgetown University Press; 2010.

45 - Rauprich O, Vollmann J. 30 Years Principles of biomedical ethics: introduction to a symposium on the $6^{\text {th }}$ edition of Tom L Beauchamp and James F Childress' seminal work. J Med Ethics. 2011; 37(10):592-596. 
46 - Karlsen JR, Solbakk JH. A waste of time: the problem of common morality in Principles of Biomedical Ethics. J Med Ethics. 2011; 37(10):588-591.

47 - Rauprich O. Specification and other methods for determining morally relevant facts. J Med Ethics. 2011; 37(10):592-596.

48 - Gordon JS, Rauprich O, Vollmann J. Applying the four-principle approach. Bioethics. 2011; 25(6):293-300.

49 - Beauchamp TL. Making principlism practical: a commentary on Gordon, Rauprich, and Vollmann. Bioethics. 2011; 25(6):301-303.

50 - Herissone-Kelly P. Determining the common morality's norms in the sixth edition of Principles of Biomedical Ethics. J Med Ethics. 2011; 37(10):584-587.

51 - Garrafa V. Bioética, saúde e cidadania. Humanidades (UnB). 1994; $9(4): 342-351$.

52 - Lepargneur H. Força e fraqueza dos princípios da bioética. Bioética (CFM). 1996; 4(2):131-43.

53 - Pessini L, Barchifontaine CP. Bioética: do Principialismo à busca de uma perspectiva latino-americana. p. 81-96. In: Costa SIF, Garrafa V, Oselka G (coord.). Iniciação à Bioética. Brasília: Conselho Federal de Medicina; 1998.

54 - Garrafa V, Diniz D, Guilhem D. Bioethical language and its dialects and idioletcts. Cadernos de Saúde Pública. 1999; 15(1):35-42.

55 - Garrafa V. Prado MM. Mudanças na Declaração de Helsinki: fundamentalismo econômico, imperialismo ético e controle social. Cadernos de Saúde Pública. 2001; 17(6): 1489-1496.

56 - Garrafa V, Porto D. Intervention bioethics: a proposal for peripheral countries in a context of power and injustice. Bioethics. 2003; 17(5-6):399-416.

57 - Garrafa V. Ampliação e politização do conceito internacional de bioética. Bioética (CFM). 2012; 20(1):09-20).

58 - Unesco - Organização das Nações Unidas para a Educação, Ciência e Cultura. Declaração Universal sobre Bioética e Direitos Humanos. 33a Sessão da Conferência Geral da Unesco, 19 de outubro de 2005. Disponível em http://unesdoc.unesco.org/images/0014/001461/146180por.pdf > Acesso em: 02/09/2011.

59 - Barbosa SN. A participação brasileira na construção da Declaração Universal sobre Bioética e Direitos Humanos da Unesco. Revista Brasileira de Bioética. 2006; 2(4):423-436. 
60 - Garrafa V. O novo conceito de bioética. In: Bases conceituais da bioética. Garrafa V, Kottow M, Saada A (orgs.). São Paulo: Editora Gaia/UNESCO, pp. 09-15; 2006.

61 - Garrafa V, Kottow M, Saada A (coords.). Estatuto epistemológico de la Bioética. México: Ed. Unam/Unesco; 2005.

62 - Garrafa V, Kottow M, Saada A (orgs.). Bases Conceituais da Bioética: enfoque latino-americano. São Paulo: Ed. Gaia/Unesco; 2006.

63 - Garrafa V. Verbetes: bioética de intervención; imperialismo moral bioética y política. In: Tealdi JC (Org.). Diccionario Latino-Americano de Bioética. Bogotá: Ed. da UNESCO; 2006.

64 - Habermas J. Between facts and norms: contributions to a discourse theory of law and democracy. Trad. William Regh. Cambridge: The MIT Press; 1996.

65 - Costa SIF, Garrafa V. Oselka G. Apresentando a Bioética. p. 15-18. In: Costa SIF, Garrafa V. Oselka G (coord.). Iniciação à Bioética. Brasília: Ed. do Conselho Federal de Medicina; 1998.

66 - Bardin L. Análise de Conteúdo. $1^{\text {a }}$ reimpressão da $1^{\text {a }}$ ed. Lisboa: Edições 70; 2011.

67 - Gibbs G. Análise de dados qualitativos. Porto Alegre: Ed. Artmed; 2009.

68 - Beauchamp TL, Childress JF. Principles of biomedical ethics. $2^{\mathrm{a}}$ ed. Nova York: Oxford University Press; 1983.

69 - Beauchamp TL, Childress JF. Principles of biomedical ethics. $5^{\mathrm{a}}$ ed. Nova York: Oxford University Press; 2001.

70 - Beauchamp TL, Childress JF. Principles of biomedical ethics. $6^{a}$ ed. Nova York: Oxford University Press; 2009.

71 - Donagan A. The Theory of Morality. Chicago: The University of Chicago Press; 1977.

72 - Peterson B. Wide Reflective Equilibrium and the Justification of Moral Theory. p. 127-134. In: Burg WVD, Willigenburg TV. Reflective Equilibrium Essays in Honor of Robert Heeger. Dordrecht: Kluwer Academic Publishers; 1998.

73 - Strong C. Kukla's argument against common morality as a set of precepts On stranger tides. Cambridge Quarterly of Healthcare Ethics. 2014; 23: 93-98.

74 - Hester DM. Introduction - common morality. Cambridge Quarterly of Healthcare Ethics. 2014; 23: 73-74. 
75 - KUKLA R. Response to Strong and Beauchamp - at world's end. Cambridge Quarterly of Healthcare Ethics. 2014; 23: 99-102.

76 - Beauchamp TL. On common morality as embodied practice - A reply to Kukla. Cambridge Quarterly of Healthcare Ethics. 2014; 23: 86-93.

77 - KUKLA R. Living with pirates - common morality and embodied practice. Cambridge Quarterly of Healthcare Ethics. 2014; 23: 75-85.

78 - Beauchamp TL, Childress JF. Princípios de Ética Biomédica. $4^{\mathrm{a}}$ ed (tradução para o português). São Paulo: Ed. Loyola; 2002.

79 - Oliva LM. La equidad en la asignación de recursos en salud. una conciliación entre la ética de máximos y el mínimo decente. Clinica y Ciencia. 2004; 2(1):02-09. 